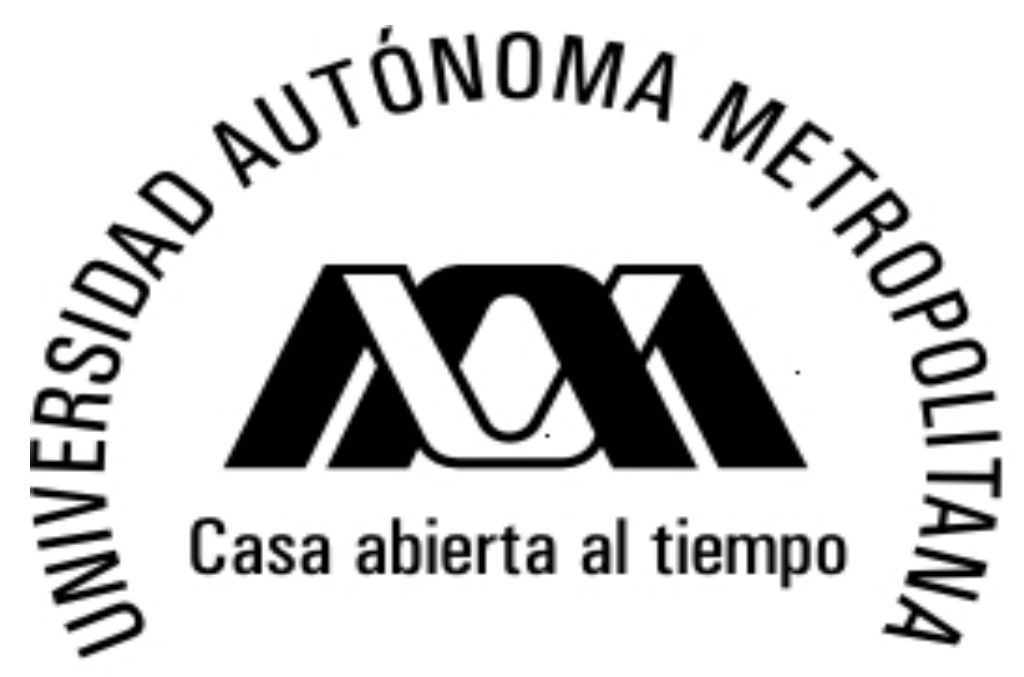

UNIVERSIDAD AUTÓNOMA METROPOLITANA-IZTAPALAPA

División de Ciencias Sociales y Humanidades

Maestría en Humanidades

Línea Teoría literaria

\title{
AL MARGEN: LITERATURA FANTÁSTICA \\ Y FUNCIÓN SOCIAL EN LA NARRATIVA DE RICARDO PIGLIA
}

Tesis que presenta el Maestro Ángel Alfonso Macedo Rodríguez

Para obtener el grado de Doctor en Humanidades (Literatura)

Asesora: Doctora Ana Rosa Regina Domenella Amadio

Lectoras: Doctora Liliana Irene Weinberg Marchevsky y Doctora Laurette Godinas

Ciudad de México, 3 de octubre de 2011 
A Claudia, mi esposa y mi musa

A Alfonso, mi hijo, cuya imaginación y perspicacia siempre me asombran

A la profesora Ana Rosa Domenella, por su generosidad, su amistad y su confianza

A la memoria de mi padre 


\section{Í N D I C E}

Marco teórico. La literatura fantástica en la órbita de la metaficción y la intertextualidad. . . . . . . . . . . . . . . . . . . . . . 6

La gran polémica sobre el realismo $\ldots \ldots \ldots \ldots \ldots \ldots \ldots \ldots \ldots \ldots \ldots$

Metaficción e intertextualidad: figuras de lo fantástico ............... 10

Lo fantástico . . . . . . . . . . . . . . . . . . . . . . . . . . . . 19

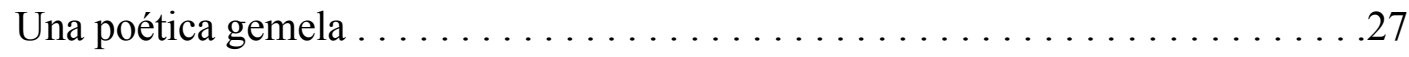

I. Transformando los modos de leer y escribir: Respiración artificial y los textos del pasado ......................................... 32

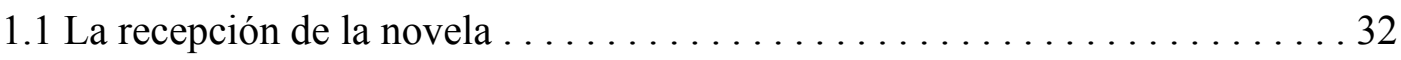

1.2 Las cartas del pasado y del porvenir. El planeta de Mr. Sammler y otros $[$ inter $]$ textos . . . . . . . . . . . . . . . . . . . . . . . . . 35

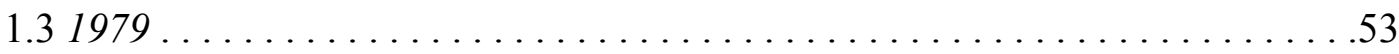

II

II. La ciudad ausente: novela infinita . . . . . . . . . . . . . . . . . . 63

2.1. La ciudad ausente en la encrucijada de los géneros: ¿Literatura fantástica o

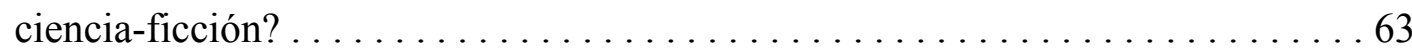

2.2. La máquina Elena y sus relatos: metaficción y función política . . . . . . 80

2.3 "La nena": relato especular de La ciudad ausente ................... 99

2.3 .1 Una muñeca rusa . . . . . . . . . . . . . . . . . . . . . . . 99

2.3.2 Entre el género fantástico, el psicoanálisis y la tradición literaria ........108

2.4 La ciudad ausente y el cine: notas para un acercamiento interdisciplinar . . 116

2.4.1 Tradiciones cinematográficas y literarias . . . . . . . . . . . . . . 116

2.4.2 De mundos paralelos . . . . . . . . . . . . . . . . . . . . 121 
III. Una poética de lo fantástico: "Encuentro en Saint-Nazaire” y las múltiples versiones de un relato . . . . . . . . . . . . . . . . . . . . . 127

$3.1 \mathrm{El}$ arte de la difracción . . . . . . . . . . . . . . . . . . . 128

3.2 Versiones y di-versiones, evolución literaria y sociedad . . . . . . . . . 132

3.3 Entre el tema del doble y lo múltiple ....................... 139

3.4 El Aleph de Piglia ................................... 146

Conclusiones. La literatura después de Piglia . . . . . . . . . . . . . . . . . . 174

Anexo. Entrevista a Ricardo Piglia ............................. 181

Bibliografía .....................................195 
Si algo caracteriza el fantástico es, por un lado, el déjà vu y por el otro, el desmoronamiento de toda frontera entre realidad y ficción. MARÍA NEGRONI, Galería fantástica

La ficción no es, por lo tanto, una reivindicación de lo falso. Aun aquellas ficciones que incorporan lo falso de un modo deliberado -fuentes falsas, atribuciones falsas, confusión de datos históricos con datos imaginarios, etc.-, lo hacen no para confundir al lector, sino para señalar el carácter doble de la ficción, que mezcla, de modo inevitable, lo empirico y lo imaginario. JUAN JOSÉ SAER, El concepto de ficción

A menudo, la idea de alguien que sólo tiene un libro en el que se cifra un mundo perdido se reproduce en una escala ampliada. Orwell en 1984, Bradbury en Fahrenheit 451, Aldous Huxley en Un mundo feliz, entre otros, han narrado mundos futuros en los que el acto de leer ha sido prohibido y la lectura considerada una práctica subversiva. Es la condensación de la amenaza pura: una sociedad que liquida cualquier tipo de autonomía, ocupa todos los espacios e impide la privacidad. Sin embargo, en esos relatos en los que la lectura está controlada y prohibida, siempre hay alguien que lee: un único lector o una asociación secreta de lectores en fuga. RICARDO PIGLIA, El último lector 


\title{
MARCO TEÓRICO. LA LITERATURA FANTÁSTICA EN LA ÓRBITA \\ DE LA INTERTEXTUALIDAD Y LA METAFICCIÓN
}

\author{
Los géneros literarios dependen menos de los textos \\ que del modo en que éstos son leídos. \\ JORGE LUIS BORGES \\ Macedonio invierte la relación que definen las grandes teorías \\ de Auerbach, de Lukács y de Bajtín: para él no se trata de buscar \\ la realidad en la novela, sino de buscar la novela en la realidad. \\ La novela no sólo actúa y produce efectos en lo real sino que aspira a construir \\ lo no-real, lo que está por venir y lo que todavía no es. \\ RICARDO PIGLIA, Diccionario de la novela de Macedonio Fernández
}

\section{La gran polémica sobre el realismo}

Veinte años antes de la publicación de La ciudad ausente (1992), cuando solo tenía publicado su primer libro de relatos, La invasión, y algunos artículos críticos -como el dedicado a La traición de Rita Hayworth de Manuel Puig-, Ricardo Piglia (1941) publicó un volumen con estudios sobre el realismo en la literatura. No se trataba de ensayos escritos por él, sino de una curiosa recopilación teórica que recuperaba diversas posiciones sobre el realismo, en el contexto de los años de transición del marxismo al estructuralismo y de este a la semiótica.

Editado por primera vez por Tiempo Contemporáneo, casa en la que el escritor argentino colaboró y dio a conocer diversas antologías, como las del género negro, Polémica sobre realismo ya ofrecía, de entrada, esa selección ordenada de modo arbitrario: aparecen en ese libro textos de Georg Lukács, Theodor W. Adorno, Ernst Fisher, Roland Barthes y Roman Jakobson. El orden, como se ve, no es cronológico, pues la disposición textual está encaminada a establecer un diálogo sobre el realismo y las literaturas 
"marginales", como la fantástica y la policial. Aunque Piglia dé comienzo a la antología con la polémica establecida por la visión rígida sobre la literatura que tenía Lukács, e inmediatamente después agregue la respuesta de Adorno (bien pudo haber colocado, también, los textos de Bertolt Brecht o de Walter Benjamin) como un modo de ubicar la opinión de algunos integrantes de la Escuela de Frankfurt frente a la del crítico húngaro -la polémica principal se desata, sobre todo, por el ataque de Lukács a la obra de Kafka por considerarla alejada de la realidad, y por la defensa que hacen Brecht, Benjamin y Adornola continuación de la polémica se extiende hacia las visiones aparentemente esteticistas de Roland Barthes y Roman Jakobson. El penúltimo texto corresponde al crítico francés, quien anticipa que el método estructural no había logrado aprehender los detalles de las obras literarias que analizaba, pues su acercamiento se concentraba, principalmente, en las estructuras y en lo narratológico, no en los detalles. En ese texto, el autor de "La muerte del autor" sugiere una lectura más atenta a los intersticios, que conecte un texto con otros a partir de la identificación de detalles. Esta postura, junto con la de las breves páginas de “La muerte del autor”, lo acercará a una incipiente teoría de la intertextualidad que años más tarde desarrollará otro estudioso estructuralista de gran importancia, Gérard Genette. Pareciera que, en el estudio de un esquema rizomático, y no en el que postule una estructura ordenada y sistematizada, se encuentra el futuro de los estudios literarios: Barthes, Genette e incluso Deleuze y Guattari se encuentran muy activos en esa década de los setenta, publicando y preparando textos que cambiarían los modos de leer de la crítica.

A pesar de la visión tan contemporánea que ofrece el texto de Barthes, y que hubiera sido suficiente para que con él se cerrara el volumen, Piglia decide que el último texto sea "Sobre el realismo artístico" de Roman Jakobson, pieza central de la antología que Tzvetan Todorov había publicado siete años antes en Francia, en el volumen que recuperaba algunos 
grandes textos de los formalistas rusos. En un giro que repetiría en compilaciones futuras (como en Las fieras, antología que ofrece la lectura de cuentos clásicos argentinos como si pertenecieran al género negro, y que termina con el relato homónimo de Roberto Arlt, o La Argentina en pedazos, libro híbrido que aglutina reflexiones de Piglia e historietas sobre algunas escenas fundamentales de la literatura rioplatense -incluye "La gallina degollada" del uruguayo Horacio Quiroga, en otro gesto que rompe toda regla de categorización- y que termina con "La agonía de Haffner, el Rufián Melancólico", uno de los capítulos de Los lanzallamas), el autor de Prisión perpetua sugiere así que el texto de Jakobson es de gran actualidad en la teoría literaria: el debate sobre el realismo queda abierto.

En esta recopilación, Ricardo Piglia establece una línea dual que, en cierto sentido, recorrerán sus textos de creación, de acuerdo con el modo en que desea que sean leídos:

1) En esa Polémica..., concilia al marxismo con el formalismo ruso y el estructuralismo.

2) En cierto modo, agotada la polémica iniciada con Lukács y clausurada por la Escuela de Frankfurt $^{1}$-nunca más se discutirá la pertinencia y la presencia de Kafka por no seguir el programa realista-marxista-, se abre un nuevo espacio de discusión: ¿cómo narrar en la Argentina, en el contexto de la revista Contorno -cuyos integrantes, entre ellos David Viñas, como buena parte de los jóvenes universitarios, leían a Borges como un autor reaccionario- tomando en cuenta el método formal heredado de los lingüistas y críticos rusos?

\footnotetext{
1 Aunque la discusión ya no toma en cuenta las ideas de Lúkacs sobre Kafka, el debate continuó en la refutación de Hans Robert Jauss a la Escuela de Frankfurt y Adorno a propósito de la visión apocalíptica de este en cuanto a la relación entre arte y vanguardia, la función de los receptores y los mass media. Sin embargo, lo que Jauss le reprocha a Adorno podría tener su contrarréplica no en Adorno, ciertamente "negativista" en su estética, sino en Benjamin y los modos revolucionarios de apropiación de los medios, en síntesis con la vanguardia. Sobre la estética de la recepción y la polémica con Adorno, cfr. Hans Robert Jauss, Experiencia estética y hermenéutica literaria, trad. de Jaime Siles y Ela Ma. Fernández Palacios, Taurus, Madrid, 1986, p. 26.
} 
3) En "Sobre el realismo artístico", de 1921, Jakobson demuestra el agotamiento en el que ha caído el realismo cuando intentó hacer de toda narración un espejo de la realidad, enarbolando la bandera de la verosimilitud a toda costa. De acuerdo con el lingüista ruso, el discurso adquiere su acta de independencia en el lenguaje, pues la connotación de las palabras excede su sentido literal ${ }^{2}$. Con este texto final que sugiere que el estudio del lenguaje puede desarticular toda posición dogmática, Ricardo Piglia continúa el debate en Argentina sobre lo que Macedonio Fernández y Borges habían comenzado décadas atrás: la literatura fantástica, justamente, abre la posibilidad de salir de los relatos escleróticos y anodinos del realismo de los siglos XIX y XX.

Este desgastado realismo decimonónico es el que Macedonio Fernández se propuso combatir en Museo de la Novela de la Eterna. Siguiendo ese programa, y ofreciendo un aporte que propone la visión de Macedonio como un escritor subversivo, a la misma altura de Roberto Arlt, Piglia llegará a uno de sus grandes momentos como escritor en La ciudad ausente. Su crítica no estará centrada únicamente en las posiciones estéticas tradicionalistas a propósito del realismo y el concepto de verosimilitud (como la de Auerbach en Mímesis, en cierto sentido), sino también en una posición política que cuestiona el principio de la realidad y el control de la verdad, detentados por el Estado. Como en su compilación teórica sobre el realismo, que concilia la visión marxista con el método y el estudio formal del lenguaje y la creación poética, Piglia encuentra en la vanguardia (sea teórica, como la de los formalistas rusos, Mijaíl Bajtín o Walter Benjamin; sea poética, como la de Macedonio) la rama que une lo estético con lo político:

\footnotetext{
2 "Sin duda habrá hombres pacíficos, cuyo nombre sea Pacífico. Eso no nos permite calificar a cada Pacífico de pacífico" (Roman Jakobson, "Sobre el realismo artístico", en Tzvetan Todorov (comp.), Teoría de la literatura de los formalistas rusos, Siglo XXI, México, 1991, p. 79. Cfr. también Ricardo Piglia, Polémica sobre realismo, Editorial Buenos Aires, Barcelona, 1982).
} 
Realismo. Macedonio opone la "estética de la invención" a la estética realista (estética de la invención vs estética de la representación) y, con ello, desacredita las nociones tradicionales de verdad, verosimilitud, alucinación del lector, y propone un método o técnica de la novela desde cuyos "artilugios de inverosimilitud" desmiente la idea de verosimilitud del relato ${ }^{3}$.

En el arte, todo acto vanguardista es una provocación al sistema cultural establecido. En ese sentido, la literatura fantástica, leída como una declarada provocación al realismo, y escasamente analizada en la narrativa pigliana por parte de la crítica, ofrece una mirada lúdica y de resistencia social que permite la incorporación del escritor argentino a una tradición literaria específica y a un género considerado todavía marginal que, por esa razón, sigue siendo el símbolo de la rebeldía ante la institucionalización de géneros más canónicos, como la novela realista del siglo XX en la Argentina.

\section{Metaficción e intertextualidad: figuras de lo fantástico}

Una de las líneas de investigación de este trabajo es el estudio de tres problemas literarios que serán leídos en el contexto de la poética de Ricardo Piglia: la literatura fantástica, la metaficción y la intertextualidad, que pueden ser entendidos y empleados como géneros (en el caso del primero) y como procedimientos poéticos (en el caso de los últimos) propios de escritores que, como el argentino, forman parte de una sofisticada tradición que se encuentra en diálogo permanente con la cultura de masas.

En esa tradición literaria, que no solo incluye a los escritores argentinos, sino también a algunos autores uruguayos que siempre mantuvieron una relación con la Argentina por su cercanía geográfica y estética a través del Río de la Plata (Horacio Quiroga, Felisberto

\footnotetext{
${ }^{3}$ Ricardo Piglia (ed.), Diccionario de la Novela de Macedonio Fernández, FCE, Buenos Aires, 2000
} (Tezontle), p. 88. La definición es de Elena Vinelli. 
Hernández, Juan Carlos Onetti, entre otros), Piglia se inserta en esa línea canónica de las letras universales que sigue teniendo uno de sus pilares más sólidos en la figura y el proyecto estético de Borges; simultáneamente, el autor de Respiración artificial ha contribuido, con sus textos narrativos y sus reflexiones escritas y orales, a un nuevo modo de leer a aquellos autores que, en su tiempo, fueron marginados de los grandes círculos literarios: tales serían los casos de Roberto Arlt y Witold Gombrowicz. Asimismo, establece una relación genealógica y poética con autores de la vanguardia argentina, como Macedonio Fernández o Leopoldo Marechal ${ }^{4}$.

El cruce de tradiciones diversas, antagónicas en algunos casos, ha hecho que, en parte, la narrativa de Ricardo Piglia refleje un proyecto literario autorreferencial que sugiere, explícita e implícitamente, su ubicación dentro de las poéticas mencionadas. Las prácticas intertextuales, las estructuras metaficcionales y el giro cada vez más evidente a la literatura fantástica sugieren nuevos caminos de una poética que se encuentra siempre en proceso de

\footnotetext{
${ }^{4}$ La poética de Ricardo Piglia asedia permanentemente el canon literario rioplatense, ubicando en el centro a aquellas figuras paradigmáticamente marginales, como Gombrowicz, y poniendo en duda la importancia de aquellos escritores que terminaron por repetirse a sí mismos, haciendo "best sellers refinados", o que se automatizaron con el paso de los años, hasta convertirse en los "poetas nacionales", defensores radicales de la pureza del lenguaje. Tales serían los casos de Manuel Mujica Lainez en los comentarios vertidos a través de Emilio Renzi en Respiración artificial (Anagrama, Barcelona, 2001 (Narrativas hispánicas, 300), p. 141) y Leopoldo Lugones (Ibid., p. 136), respectivamente. Sobre el diálogo ininterrumpido que el escritor de Adrogué mantiene con Borges y Arlt, Rose Corral afirma: "Si Piglia vuelve insistentemente la mirada sobre Borges y Arlt es porque su reflexión sobre estos escritores se asocia estrechamente a su propia escritura y también a sus búsquedas (que comparte con varios escritores de su generación) en torno a las relaciones entre literatura y política" (Rose Corral, "Borges/Arlt: relecturas polémicas de la tradición", Roberto Arlt: una poética de la disonancia, El Colegio de México, México, 2009, p. 105). En la línea que recupera ese signo lingüístico dual (Borges: significante; Arlt: significado, en cierto sentido) de los dos maestros argentinos de Piglia, Laurette Godinas profundiza en la función de conjura que es inherente al proyecto literario de los tres autores (Cfr. Laurette Godinas, "La secreta sociedad: Arlt, Borges y Piglia", Signos literarios y lingüísticos (México), v. V, núm. 1, enero-junio de 2003, pp. 53-71). Por su parte, Diego Poggiese observa una postura perversa en Piglia cuando afirma que este "construye una tradición en la que se inscribe [...] y en la que debería ser inscripto aún sin decirlo él, ya que necesariamente las lecturas que él hace desembocan en lo que él escribe en sus novelas" ("El peso de una verdad otra [o cómo diseñar el monumento a uno mismo]", en Alberto Giordano y María Celia Vázquez [comps.], Las operaciones de la crítica, Beatriz Viterbo Editora, Rosario, 1998, p. 162).
} 
transformación ${ }^{5}$ : el discurso metacrítico en sus novelas, cuentos, relatos y notas de diario siempre contribuye a una nueva revisión de la labor poética y de sus contextos de recepción.

Como ya se ha analizado en otros momentos, la literatura de Ricardo Piglia ha dado un giro cada vez más visible a la literatura fantástica. Este acercamiento a uno de los géneros más emblemáticos de la literatura rioplatense desde Leopoldo Lugones, pero con una tradición canónica legitimada desde la publicación de las novelas, los cuentos y las antologías de Borges y Bioy Casares, es mucho más visible desde la publicación de La ciudad ausente en 1992, los Cuentos morales de 1995, algunos cuentos y relatos de Formas breves (1999) y el "Prólogo" a El último lector $(2005)^{6}$.

En esta investigación, me propongo establecer una relación dialógica entre la intertextualidad, la metaficción y el género fantástico como parte de los recursos literarios que Ricardo Piglia emplea en su narrativa, tomando como elemento central la teoría de la literatura fantástica. En la novela La ciudad ausente y en uno de los relatos salidos de la máquina de narrar, la nouvelle "Encuentro en Saint-Nazaire", así como en algunos fragmentos de Respiración artificial y los textos mencionados en el párrafo anterior, Piglia exhibe un discurso de lo fantástico producido a través de ciertos procedimientos intertextuales y metaficcionales que le dan solidez a su propuesta estética al permitir la

\footnotetext{
${ }^{5}$ Piglia menciona, irónicamente, a propósito de la publicación de su cuarta novela, Blanco nocturno, que lo que se esperaba de él era una obra en la línea de La ciudad ausente: urbana, vanguardista, de ruptura. Con aquella novela, teniendo al campo no solo como espacio de las acciones, sino como tema, el autor argentino sostiene: "Ha sido mi gesto vanguardista". Cfr. "Uno siempre escribe contra algo", nota de Carolina Andreotti y Alejandro Chacón, El mundo (Madrid), 9 de septiembre de 2010, http://www.elmundo.es/elmundo/2010/09/09/cultura/1284069552.html, página consultada el 24 de julio de 2011.

${ }^{6}$ Sobre la perspectiva de lo fantástico como parte de la poética de Piglia en los textos de los dos últimos volúmenes mencionados, cfr. los caps. IV y V de mi tesis de maestría: De la crítica a la ficción y de la ficción a la crítica: una lectura sobre la poética de Ricardo Piglia, Universidad Autónoma Metropolitana-Iztapalapa, México, 2007, pp. 99-155.
} 
identificación de una genealogía literaria que comparte temas, enfoques, posiciones y figuras poéticas con la literatura de Borges; simultáneamente, toma distancia de este al acercarse de un modo distinto a las llamadas literaturas "marginales", como el género negro o la ciencia ficción de autores también considerados marginales o cuya obra se acerca más a la cultura de masas (tal es el caso de Philip K. Dick). Así, lo que podríamos calificar como práctica inmanentista en Borges adquiere en la literatura de Piglia una función política que le permite reflexionar sobre la creación literaria como un espacio de resistencia social: como bien lo recuerda Graciela Speranza, el autor de Adrogué recupera al creador de Ficciones para la izquierda a partir de ensayos como "Ideología y ficción en Borges"”. Piglia es uno de los escritores jóvenes de las décadas de los sesenta y setenta del siglo pasado que establece un acercamiento entre los textos de Arlt y Borges: leer a este como un escritor profundamente político es una suerte de apropiación que le permite dialogar con la tradición literaria rioplatense y proponer nuevos modos de acercamiento. Uno de estos modos es, justamente, el de la oposición entre el realismo hegemónico de finales del siglo XIX y principios del siglo XX y la incipiente literatura fantástica que, mediante la publicación de la Antología de la literatura fantástica ${ }^{8}$ en 1940 y otros textos menores como Cuentos breves y extraordinarios ${ }^{9}$, contribuyó de modo definitivo al surgimiento de una nueva recepción que pudiera comprender la poética borgiana. La línea trazada que comienza con Macedonio Fernández, se consolida con Borges y cruza por autores como

\footnotetext{
${ }^{7}$ Graciela Speranza, Fuera de campo. Literatura y arte argentinos después de Duchamp, Anagrama, Barcelona, 2006 (Fundamentos, 351), p. 266. El punto de vista de Piglia permite recuperar una recepción crítica (contraria a la del grupo Contorno) sobre el autor de El Aleph en la que es leído como un escritor político, al nivel de Roberto Arlt o incluso de Brecht.

8 Jorge Luis Borges, Adolfo Bioy Casares y Silvina Ocampo, Antología de la literatura fantástica, Sudamericana / Hermes, México, 1996.

${ }^{9}$ Jorge Luis Borges y Adolfo Bioy Casares, Cuentos breves y extraordinarios [1953], Losada, México, 1997.
} 
Silvina Ocampo y Julio Cortázar, tiene en la obra de Piglia una propuesta que instala un diálogo entre esa tradición y una literatura más política.

Si el Estado intenta mantener una percepción de la realidad que le resulte conveniente, mediante la instauración de un dispositivo de control mental que se impulsa a partir de los medios masivos de comunicación y sus relatos estatales, la literatura debe encontrar aquellos procedimientos que, paradójicamente, nieguen esa realidad gubernamental al proponer una realidad alterna, nacida del género fantástico: el realismo está automatizado, las narraciones típicamente realistas no originan ningún problema de recepción en los lectores porque están "domesticadas"; en cambio, la literatura fantástica es altamente subversiva porque exige una lectura diferente y atenta, al mismo tiempo que rompe las reglas de la tradición realista y de lo que se entiende por el concepto de realidad, de la que se ha apropiado la clase política (los realities shows serían un ejemplo actual que intenta controlar el sentido de la realidad): por eso, "lo fantástico es el pasajero clandestino de la literatura", afirma Marcel Schneider ${ }^{10}$. De este modo, una de las perspectivas de la literatura fantástica estudiada por una gran parte de los teóricos literarios coincide, aunque sea parcialmente, con la función social que cumple en la narrativa del escritor argentino: al negar la realidad tal como el Estado la plantea y representa, la literatura postula una ruptura estética y social que exhibe su carácter subversivo.

De este modo, mi investigación intentará demostrar que, en la obra narrativa pigliana, el empleo de las diversas referencias intertextuales en una serie de narraciones enmarcadas dentro de una estructura metadiegética permite ver que la intertextualidad y la metaficción son procedimientos de lo fantástico que ubican la literatura de Piglia en el canon rioplatense

\footnotetext{
${ }^{10}$ Citado por Harry Belevan, Teoría de lo fantástico. Apuntes para una dinámica de la literatura de expresión fantástica, Anagrama, Barcelona, 1976 (Argumentos, 37), pp. 70-71.
} 
y en el contexto de una literatura que permite transformar la recepción de los lectores: los conceptos de desautomatización de Víktor Shklovsky y de evolución literaria de Juri Tinianov $^{11}$ son incorporados, en la poética de Piglia, dentro de una faceta dual que incluye procedimientos formales "cultos" y una posición social que postula el futuro de la literatura en las prácticas de ruptura estética que, simultáneamente, son políticas, en una síntesis tomada de la idea benjaminiana que concilia la vanguardia, la tecnología y la revolución en "La obra de arte en la época de su reproductibilidad técnica"12. Para Piglia, la verdadera vanguardia siempre es política; su modo de leer a Macedonio Fernández, a Borges, a Joyce, siempre es dual: lo estético no excluye lo social. Cruzar a Joyce con Kafka, a Borges con Arlt, a Macedonio con Benjamin, a Baudelaire con Marx, a Ítalo Calvino con Bertolt Brecht, es un modo de conciliar la vanguardia con la función política de la literatura: hay que romper lo convencional en la creación y las formas sociales rígidas para salir de lo automatizado y del control detentado por la clase política.

Lo anterior puede pensarse a partir de Kafka. Por una literatura menor de Deleuze y Guattari: "Sólo la expresión nos da el procedimiento"" escritor judío plantea el problema de la expresión en relación con las literaturas menores, es decir, aquellas escritas por una minoría en una lengua mayor: "por ejemplo, la literatura

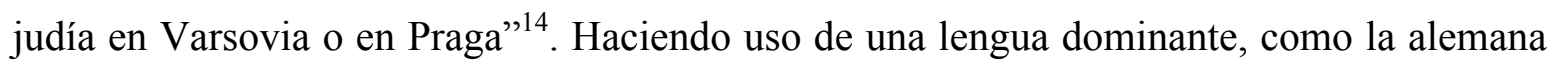

\footnotetext{
${ }^{11}$ Cfr. Víktor Shklovsky, "El arte como artificio", y Juri Tinianov, "Sobre la evolución literaria”, en Tzvetan Todorov (comp.), op. cit., pp. 55-70 y pp. 89-101, respectivamente.

${ }^{12}$ Walter Benjamin, "La obra de arte en la época de su reproductibilidad técnica", Estética y política, trad. de Tomás Joaquín Bartoletti y Julián Fava, pról. de Ralph Buchenhorst, Las Cuarenta, Buenos Aires, 2009.

${ }^{13}$ Gilles Deleuze y Félix Guattari, Kafka. Por una literatura menor, trad. de Jorge Aguilar Mora, Era, México, 2001, p. 28.

${ }^{14}$ Ibidem. Además, Deleuze y Guattari establecen una semejanza entre Kafka y Joyce, a propósito de las literaturas menores, que siempre encuentran revolucionarias (Ibid., p. 33). Esta idea también es importante para Piglia, quien ha señalado la condición marginal de algunos escritores en su relación con una lengua dominante o en su relación con los países europeos dominantes: el inglés del irlandés James Joyce, Kafka y Gombrowicz con sus países periféricos de Europa Oriental. Cfr. "La novela polaca", Formas breves, Anagrama, Barcelona, 2001 (Narrativas hispánicas, 292), pp. 72-73.
} 
a principios del siglo XX en Praga, Kafka logra hacer "lo que los negros de Estados Unidos pueden hacer actualmente con el inglés" ${ }^{\prime 15}$ : rompe desde adentro el discurso político dominante, amenazante y agresivo mediante ciertos procedimientos que provocan un efecto de desterritorialización (y de desautomatización) en la lengua mayor y en la comprensión de la obra literaria. Para Deleuze y Guattari, una literatura menor, como la del autor de $E l$ proceso, siempre es política.

De acuerdo con lo anterior, en este estudio, aunque sea de modo parcial, podemos leer la literatura de Piglia como menor, en el sentido estético-político de sus procedimientos literarios: el cultivo de la oralidad en el discurso de sus personajes -lo que abre la posibilidad de hacer paréntesis narrativos cuando se comienzan a relatar múltiples historias, incluyendo la interrupción como modelo de conversación cotidiana ${ }^{16}$, la escritura de un diario que puede predecir el futuro, las pistas bibliográficas reales y falsas que va diseminando en su obra, las alusiones, las citas, el empleo del pastiche para romper las fronteras entre lo real y lo ficcional, son solo algunos de los recursos que orientan la investigación de su poética hacia una función política y social.

La intertextualidad y la metaficción son dos procedimientos literarios que se estudian en el marco de la escuela estructuralista y en el marco de la semiótica como "ciencia de las

\footnotetext{
${ }^{15}$ Gilles Deleuze y Félix Guattari, op. cit., p. 29.

${ }^{16}$ Un ejemplo: cuando en La ciudad ausente, al principio, el narrador presenta a Junior como el investigador central de la trama, hay una digresión importante: Emilio Renzi narra los infortunios lingüísticos (y políticos) del académico húngaro Lazlo Malamüd, sugiriéndose así, desde el inicio de la narración, que la novela atravesará múltiples discursos orales y escritos, rompiendo, de este modo, toda estructura cronológica lineal, convencional en la narrativa tradicional (cfr. Ricardo Piglia, La ciudad ausente, Anagrama, Barcelona, 2003, (Narrativas hispánicas, 340), pp. 15-17). De paso, hay que señalar que el caso de Malamüd es típicamente kafkiano a propósito de su silencio y su imposibilidad de hablar en una lengua extranjera, lo que conecta su caso con el estudio de literatura menor en Kafka de Deleuze y Guattari. Para un análisis más profundo de este fragmento, cfr. Alfonso Macedo Rodríguez, "La metaficción y la intertextualidad: figuras de lo fantástico en La ciudad ausente”, Signos literarios, v. V, núm. 10, julio-diciembre de 2009, pp. 62-65.
} 
significaciones" y como "ciencia de los discursos"17. El estructuralismo ofreció una serie de aportes fundamentales en el campo de los estudios literarios, principalmente en la narratología. En el transcurso del estudio de las estructuras, donde la metadiegética ${ }^{18}$ posee un lugar especial, se desprendieron nuevos estudios, más cercanos a la semiótica, como los de Gérard Genette en Palimpsestos, cuyo objeto de estudio es la intertextualidad, vista desde un enfoque teórico y analizada en la selección de textos del crítico francés, que incluye fragmentos de la Iliada, el Quijote y la versión no metadiegética de Unamuno, los cuentos de Borges, etcétera ${ }^{19}$. Desde la perspectiva de la pragmática, que no sólo es heredera de los estudios precursores de la semiótica de Charles Sanders Peirce en Estados Unidos, sino también del concepto de "función" de Tinianov y de otros eminentes formalistas rusos, así como de Jan Mukarovsky en Praga, Linda Hutcheon estudia las "funciones" de la parodia y la sátira, analizándolas como géneros literarios dentro del cultivo de la ironía literaria ${ }^{20}$. Así, Genette y Hutcheon, en el contexto del formalismo ruso,

\footnotetext{
${ }^{17}$ Julia Kristeva, Semiótica, v. 1, trad. de José Martín Arancibia, Fundamentos, Madrid, 1978, p. 22. Mucho antes de Kristeva, Ferdinand de Saussure definió la semiología (término más común en la tradición francesa, que incluye a Roland Barthes) como "la ciencia de los signos" (Ferdinand de Saussure, Curso de lingüistica general, trad. de Mauro Armiño, Fontamara, México, 1998, pp. 42-43). En todo caso, la semiología o la semiótica (término más usual en los contextos estadounidense y ruso) es una ciencia de los signos que analiza los modos en los que el receptor produce la semiosis al reconocer la comunicación y la comprensión del texto y el discurso oral.

${ }^{18}$ Cfr. Gérard Genette, Nuevo discurso del relato, trad. de Marisa Rodríguez Tapia, Cátedra, Madrid, 1998 (Crítica y estudios literarios), p. 58.

${ }^{19}$ Gérard Genette, Palimpsestos. La literatura en segundo grado, trad. de Celia Fernández Prieto, Taurus, Madrid, 1989. En De la crítica a la ficción, op. cit., estudié la poética de Piglia a partir del estudio de la intertextualidad en algunos de sus cuentos; ahora, retomo el trabajo de Genette para acercarme a dos novelas y una nouvelle con la finalidad de estudiarlas dentro de la órbita de la literatura fantástica. Por su parte, en el estudio que José Manuel González Álvarez hace de algunos textos breves y de autoficción en la obra de Piglia, hay un acercamiento dedicado a las prácticas intertextuales del escritor argentino desde la teoría de Genette. En esas páginas, González interpreta el empleo de la intertextualidad de Piglia como un homenaje al estudioso francés. Sin embargo, lo que debe tomarse en cuenta, en realidad, es que tanto Piglia como Genette (cada uno por su lado), elaboran e interpretan, respectivamente, una práctica intertextual que en buena medida proviene de la tradición literaria consolidada en la obra de Borges. Para el estudio de la intertextualidad en Piglia como fundamento teórico, cfr. José Manuel González Álvarez, "Genette y Piglia: los palimpsestos fraudulentos", En los "bordes fluidos": formas híbridas y autoficción en la escritura de Ricardo Piglia, Peter Lang, Bern, 2009, pp. 16-28.

${ }^{20}$ Linda Hutcheon, "Ironía, sátira, parodia. Una aproximación pragmática a la ironía", trad. de Pilar Hernández Cobos, en De la ironía a lo grotesco (en algunos textos literarios hispanoamericanos), UAM-I,
} 
el estructuralismo francés y la semiótica, analizan algunos ejemplos de las literaturas occidentales que son productoras de semiosis a partir del estudio de sus funciones en la literatura. Tales estudios serán una base metodológica para el acercamiento a las marcas intertextuales que he seleccionado de la narrativa de Ricardo Piglia ${ }^{21}$.

En el campo de la metaficción, la narratología francesa (cuyo máximo representante es probablemente Gérard Genette) analiza aquellos relatos que se encuentran "enmarcados" por una voz narrativa que "abre" el discurso a otro nivel, produciendo un efecto metadiegético. En muchas ocasiones, la estructura metaficcional se acerca a la poética de lo fantástico. Dentro de la tradición retórica (como parte de su formación académica), pero sin abandonar el método estructural (cuyo legado más visible quizá sea Figuras) y muy cerca de la semiótica, Gérard Genette analiza el recurso de la metalepsis en diversos textos literarios y cinematográficos ${ }^{22}$. Para este crítico y teórico francés, la metalepsis consiste, siguiendo a Fontanier, "en transformar a los poetas en héroes de las hazañas que celebran [o en] representarlas como si ellos mismos causaran los efectos que pintan o cantan, cuando un autor es representado o se representa como alguien que produce por sí mismo aquello que, en el fondo, sólo relata o describe ${ }^{, 23}$. La cita muestra que la metalepsis es un procedimiento donde el autor se convierte en personaje y narrador de las acciones; esta práctica, que en realidad ya está presente en los textos de la tradición grecolatina, tiene un

México, 1992; A theory of parody. The Teachings of Twentieth-Century Art Forms, University of Illinois Press, Urbana-Chicago, 2000.

${ }^{21}$ Este estudio de la intertextualidad busca establecer asociaciones entre la literatura de Piglia y la de aquellos autores con los que existen puntos de contacto, sobre todo en cuanto a la tradición literaria en la que Piglia intenta ser leído. Pero, además, lo importante en el estudio de la intertextualidad es identificar las funciones que las alusiones, las citas, los plagios, los pastiches, cumplen en la creación pigliana. El propio escritor sugiere algunas rutas de estudio, en diálogo permanente con la línea teórica de los formalistas rusos: "Yo tiendo a distanciarme de la noción de intertextualidad como un camino de la crítica que busca siempre rastros de otros textos; más bien tiendo a pensar en [...] las relaciones con textos ya leídos" (Cfr. "Entrevista a Ricardo Piglia", infra, p. 177).

${ }^{22}$ Gérard Genette, Metalepsis. De la figura a la ficción, trad. de Luciano Padilla López, FCE, Buenos Aires, 2004 (C. P., 650).

${ }^{23}$ Ibid., pp. 10-11. Las cursivas pertenecen a la cita que Genette hace de Fontanier. 
nuevo enfoque en la literatura del siglo $\mathrm{XX}$ y en el cine: la literatura fantástica. En Metalepsis, Genette estudia brevemente algunos casos especulares de la literatura hispanoamericana: "Magias parciales del Quijote" de Borges y "Continuidad de los parques" de Julio Cortázar son los casos emblemáticos. Ambos textos dialogan con lo fantástico y no están alejados de otras narrativas, como la del filme La rosa púrpura del Cairo y la del cuento "El episodio Kugelmass" de Woody Allen. En estos cuatro ejemplos, es posible identificar el salto de los personajes de un nivel narrativo a otro, produciéndose el efecto de lo fantástico. Tomando como modelo crítico el análisis de Genette, en este estudio se analizará la nouvelle "Encuentro en Saint-Nazaire" desde su estructura metadiegética y metaléptica para relacionarla con la tradición de la literatura fantástica y establecer, de este modo, un nuevo acercamiento a la poética de Piglia. Asimismo, se analizarán algunas categorías de la metaficción a partir del estudio preliminar de Lauro Zavala a su antología del cuento metaficcional ${ }^{24}$ y de algunos supuestos teórico-críticos de Lucien Dällenbach en El relato especular ${ }^{25}$.

Así, la intertextualidad y la metaficción, en la narrativa y la poética de Ricardo Piglia, se convierten en dos figuras de lo fantástico que serán exploradas a partir de sus funciones en Respiración artificial, La ciudad ausente y "Encuentro en Saint Nazaire”.

\section{Lo fantástico}

La prolífica aparición de estudios literarios dedicados al género fantástico en las últimas décadas ha permitido la publicación de libros que analizan la bibliografía sobre el tema y

\footnotetext{
${ }^{24}$ Lauro Zavala, "Instrucciones para bailar en el abismo", Cuentos sobre el cuento. Teorías sobre el cuento $I V$, UNAM, México, 2010 (El Estudio).

${ }^{25}$ Lucien Dällenbach, El relato especular, Visor, Madrid, 1991 (Literatura y Debate Crítico, 8). Para este teórico, la mise en abyme tiene en el género policial y en la literatura fantástica dos campos privilegiados. Pone como ejemplo "La caída de la casa de Usher" de Poe (p. 79).
} 
contribuyen a una sistematización en sus diversas modalidades en los textos narrativos hispanoamericanos y europeos. Asimismo, la celebración de congresos dedicados a la literatura fantástica en las universidades latinoamericanas y la publicación de sus actas ha contribuido a un notable avance del género en la recepción crítica ${ }^{26}$.

La línea teórica para el estudio del género fantástico en el marco de la poética y la narrativa de Ricardo Piglia abarca los estudios de la escuela estructural, con Tzvetan Todorov como uno de los primeros referentes del género. Esa línea de la teoría de lo fantástico ha adoptado en las últimas décadas una posición más cercana a la semiótica pragmática, tal como se observa en el trabajo de Pampa Arán, quien recupera las posiciones de los autores que más han profundizado en el tema y ofrece una visión que incluye un acercamiento a la posición crítica neomarxista (con autores como Raymond Williams o Fredric Jameson) y los estudios culturales.

En El fantástico literario, Arán observa que el género busca “enfatizar la oposición con el mundo conocido [e] incorpora anomalías y excesos que toma de otros discursos sobre el comportamiento humano provenientes de los sistemas filosóficos, religiosos, morales y

\footnotetext{
${ }^{26}$ Algunos ejemplos de lo anterior: Ana María Morales y José Miguel Sardiñas (eds.), Odiseas de lo fantástico, Coloquios Internacionales de Literatura Fantástica, México, 2004 (en este volumen, figuran algunos textos teóricos que serán tomados en cuenta para esta tesis, como los de Pampa Arán y David Roas); Pampa O. Arán, El fantástico literario. Aportes teóricos, Narvaja Editor, Córdoba, 1999; Cynthia K. Duncan, "Hacia una interpretación de lo fantástico en el contexto de la literatura hispanoamericana", Texto crítico (Xalapa), v. XVI, núms. 42-43, enero-diciembre de 1990, pp. 53-64; Ramón Xirau, "Crisis del realismo", en César Fernández Moreno (coord. e introducción), América Latina en su literatura, Siglo XXI, México, 1978, pp. 185-203. Por otro lado, algunos estudios que se acercan a una lectura de lo fantástico en Piglia, aunque sin profundizar en el tema, son: Idelber Avelar, "Máquina apócrifa, alegoría del duelo y poética de la traducción", en Adriana Rodríguez Pérsico, (comp.), Ricardo Piglia: una poética sin límites, Universidad de Pittsburgh, Pittsburgh, 2004 (Serie Antonio Cornejo Polar), pp. 177-199, y Elsa Dehennin, "Subversión de la doxa narrativa en La ciudad ausente (1992) de Ricardo Piglia, en Nina Grabe, Sabine Lang y Klaus MeyerMinnemann (eds.), La narración paradójica. "Normas narrativas” y el principio de la "transgresión”, Iberoamericana, Vervuert Verlag, Madrid, 2006, pp. 221-235, si bien esta última solo analiza la paradoja como práctica literaria en Piglia. (De paso, reflexionemos sobre la característica metalingüística de la paradoja como una figura lógica, cuyo discurso autorreferencial se convierte en un recurso fantástico, como se verá en las siguientes páginas.)
} 
científicos, especialmente"27. Esa oposición es parte de una "función social" que los escritores del género asumen, velada o explícitamente, en sus relatos. De este modo, ya desde la primera página de su estudio, Arán intenta legitimar el discurso fantástico desde una visión de lo social, cuyas narraciones no son inmanentes, sino que siempre están inscritas dentro de un contexto social, un espacio cultural que los devuelve a los receptores para que ocurra la semiosis y los textos puedan decodificarse.

La línea de los aportes teóricos de Arán crea un abanico que va del estructuralismo de Todorov y Genette, pasa por la semiótica pragmática de Peirce y aterriza en los estudios decisivos de Ana María Barrenechea y Rosmary Jackson, entre otros. Sin embargo, la línea marxista está presente en las referencias a Jean Paul Sartre como un antecedente crítico y partidario pasivo del género y a Williams y Jameson. Podría decirse que el estudio formal[ista] del género se complementa con la visión social de Arán (y con ella la de escritores como Borges, aunque sea de manera implícita) y establece, sin que ella lo mencione, una deuda intelectual con Jan Mukarovsky y Yuri Lotman, es decir, con la semiótica que permite la consolidación de un sistema teórico-crítico dual que abarque lo estético y lo social.

En el artículo más influyente para la consolidación de la línea semiótica que abarca los aspectos sociales, Mukarovsky llega a un postulado fundamental: por un lado, niega el carácter exclusivamente inmanente y hedonista de la producción artística; por otro, le da plena autonomía al signo artístico, sin que éste se convierta en un simple documento histórico-social: "Únicamente la perspectiva semiológica permite al teórico reconocer la existencia autónoma y la dinámica fundamental de la estructura artística, así como comprender el desarrollo del arte como movimiento inmanente, que se encuentra

\footnotetext{
${ }^{27}$ Pampa O. Arán, op. cit., p. 11.
} 
permanentemente en una relación dialéctica con la evolución de los demás campos de la cultura",28.

Las cursivas de Mukarovsky sugieren, a la manera de Bajtín, un diálogo que se establece entre distintos tipos de discurso, una comunicación interdisciplinaria donde la autonomía del signo artístico permite que sea analizado dentro de distintos contextos (incluyendo, naturalmente, el estético, lo que de paso produce la semiosis de la intertextualidad) y nunca de manera aislada. Todo signo artístico, incluyendo obviamente el fantástico, origina una reflexión sobre el espacio y el tiempo del presente: son el espacio y el tiempo del receptor, quien le otorga significación a la obra: "el arte, todo arte, es un hecho social" 29 .

En su línea argumentativa, Pampa O. Arán se acerca al desarrollo teórico de Ana María Barrenechea, una de las críticas pioneras en el estudio del género fantástico en Hispanoamérica. Arán analiza sus escritos (que poseen cierta influencia de Todorov) al intentar crear una tipología de lo fantástico en el contexto literario hispanoamericano y muestra que la postura teórica de Barrenechea está condicionada, en parte, por una postura semiótica menos cerrada que la estructural, que dialoga con la tradición. En el contexto de los ataques a la literatura fantástica por considerársele equívocamente poco comprometida con lo social, Barrenechea intenta establecer una perspectiva que muestre lo contrario; de acuerdo con Arán, su proyecto teórico se consolidó con los estudios dedicados a la cuentística de Borges, de los que surgió el concepto de "expresión de la irrealidad" y que funcionó para demostrar que los escritores del género fantástico contribuyen a una reflexión

\footnotetext{
28 Jan Mukarovsky, "El arte como hecho semiológico", en Nara Araújo y Teresa Delgado (selec. y apuntes introductorios), Textos de teorías y crítica literarias (Del formalismo a los estudios postcoloniales), Universidad de la Habana / UAM-I, México, 2003, p. 108.

${ }^{29}$ Harry Belevan, op. cit., p. 83.
} 
donde se cuestionan los conceptos filosóficos, religiosos, sociales y culturales establecidos. La línea teórica de Barrenechea es, por supuesto, una de las que me permitirá establecer una estrecha relación entre la literatura fantástica de Borges y Macedonio Fernández con la de Piglia. El cruce de aspectos de la realidad (y su mímesis) con las leyes que la niegan produce un acercamiento visible entre la obra de este y la de Borges.

Otra de las autoras estudiadas por Arán es Rosalba Campra, quien analiza los silencios de los personajes fantasmáticos (fantasmas, vampiros), asociándolos con la noción de lo marginal, ya que la literatura fantástica "intenta la recuperación de la voz del Otro, de los marginales de la realidad"30. De esta manera, se produce una poética fantástica de la transgresión, que busca la reflexión del lector a propósito de un género que niega, contundentemente, su supuesto carácter evasivo y escapista.

En la narrativa de Piglia, es posible identificar aquellos signos que la inscriben en un contexto social específico; un ejemplo son las referencias intertextuales de la lista de Stephen Stevensen en "Encuentro en Saint-Nazaire", que apuntan al tema del doble (la nouvelle parte del tópico del doble, sugerido en la novela Jekyl de Stevensen) y al compromiso social, sugerido en "La obra de arte en la época de su reproductibilidad técnica" de Walter Benjamin. Así, el signo dual del género fantástico exhibe su significante en la forma del relato, en su estructura metadiegética y en sus referencias intertextuales; paralelamente, su significado está conectado con algunas formas de la resistencia social: mediante el empleo de esos recursos desautomatizadores, la literatura se vuelve subversiva, crítica y denunciante de hechos atroces. No es gratuito que La ciudad ausente despliegue relatos que se encuentran enmarcados en el contexto de la época posterior a la última dictadura argentina, en la antesala del "perdón” a los militares. Un ejemplo, que será

\footnotetext{
${ }^{30}$ Pampa O. Arán, op. cit., p. 94.
} 
analizado más adelante, es el cuento "La nena", de filiación fantástica. La historia repite el motivo del anillo de Venus, de la estatua que cobra vida, pero alude veladamente a la represión y la tortura militares en la Argentina. La niña que pierde la facultad del lenguaje es atendida, inicialmente, por el doctor Arana, el verdugo de Elena, la máquina de narrar, y cuyo nombre alude a uno de los campos de concentración durante el Proceso militar. A pesar de las variantes del tópico del anillo (tomando en cuenta relatos medievales y renacentistas y llegando hasta Henry James), la referencia al médico represor no permite la evasión erudita y hedonista, sino el aterrizaje en la realidad deformada por los aparatos estatales.

Uno de los elementos fundamentales para el análisis de la metaficción como figura de lo fantástico se encuentra en algunas estructuras del género; la disposición textual de algunos relatos, ubicados en la línea de la tradición de Borges (como "Tlön, Uqbar, Orbis Tertius" o "El milagro secreto"), señala su carácter metadiegético: cuando dos niveles narrativos se cruzan (en dos historias aparentemente paralelas), se produce lo fantástico ${ }^{31}$. Bajo esta perspectiva teórico-crítica, Pampa Arán analiza las investigaciones de Rosmary Jackson, que coinciden, aunque parcialmente, con los estudios de Barrenechea sobre la expresión de la irrealidad en la narrativa de Borges. Para Jackson, la literatura fantástica se preocupa más por el discurso en la representación y menos por la temática: “al enfatizar su propia práctica significante, lo fantástico comienza a revelar que su versión de lo "real" es relativa, que sólo puede deformar y transformar la experiencia, de modo que lo "real” se expone como una categoría, algo que se articula y construye a través del texto artístico o

\footnotetext{
${ }^{31}$ Para un desarrollo más amplio del tema, cfr. mis artículos "La metaficción como recurso de lo fantástico en La fiesta brava de José Emilio Pacheco", Signos literarios y lingüísticos, (México), v. V, núm. 1, enero-junio de 2003, pp. 227-237 y "La metaficción y la intertextualidad: figuras de lo fantástico en La ciudad ausente", op. cit., pp. 57-75.
} 
literario",32. Jackson observa que la cultura actual, cultura inhumana y "de desechos",33, ha producido obras como las de Kafka, Calvino o Pynchon, que expresan esa condición de alienación y de irrealidad: las tendencias de estos y otros autores "enfatizan la literatura como construcción de algo manifiestamente irreal, como una mentira, textos autorreflexivos que juegan con su propia ficcionalidad (como los de Borges)"34; en esa línea de la tradición rioplatense se encuentra la literatura de Ricardo Piglia, quien no por casualidad es citado por Arán en uno de los apartados de su estudio: "No se trata de ver la presencia de la realidad en la ficción (realismo) sino de ver la presencia de la ficción en la realidad (utopía). El hombre realista contra el hombre utópico. En el fondo, son dos maneras de concebir la eficacia y la verdad"35.

Otro crítico que se encuentra en el eje de la teoría de lo fantástico y su función social (sin el cual lo fantástico pierde gran parte de su significación) es David Roas, quien parte del modelo borgiano de lo fantástico, estudiado con anterioridad por Barrenechea. La línea de Roas intenta establecer, nuevamente, la relación entre la "realidad objetiva [...] (se habla de la Biblia, se menciona a Lutero, Stevenson [...])"36 con lo sobrenatural, que debe entenderse dentro de lo textual, dentro del discurso literario, pero que en todo caso genera la sensación de angustia en el momento de la interpretación, del proceso hermenéutico: “¿si el mundo del texto, que funciona como el nuestro, puede verse asaltado por lo inexplicable,

\footnotetext{
${ }^{32}$ Pampa O. Arán, op. cit., p. 111.

${ }^{33}$ Ibid., p. 112.

${ }^{34}$ Ibidem.

${ }^{35}$ Ibid., p. 39. La cita también aparece en "Ficción y política en la narrativa argentina" de Crítica y ficción, Anagrama, Barcelona, 2001 (Argumentos, 267), p. 123, ensayo dedicado a reflexionar sobre la literatura de vanguardia y antirrealista de Macedonio Fernández. Una variante de lo anterior es el segundo epígrafe de este marco teórico.

${ }^{36}$ David Roas, "Contexto sociocultural y efecto fantástico: un binomio inseparable”, en Ana María Morales y José Miguel Sardiñas (eds.), op. cit., pp. 39-40.
} 
¿podría eso llegar a suceder en la realidad? Ése es el gran efecto de lo fantástico: provocar -y por lo tanto, reflejar- la incertidumbre de la percepción de lo real".

Por su parte, Harry Belevan llega a conclusiones similares. El método semiótico que desarrolló, así como la revisión de los textos clásicos del estudio del género fantástico, lo llevaron a considerar el aspecto social de la literatura fantástica como un elemento inherente que supera su aspecto lúdico si este se manifiesta de manera aislada y hedonista; resulta mucho más importante la participación del lector y los procedimientos de desautomatización que eleven el nivel intelectual y cultural: "la literatura de expresión fantástica es, en definitiva, la forma literaria más revolucionaria pues ¿no son, acaso, grandes sólo aquellas obras que crean un nuevo tipo de lector? ${ }^{37,}$ Esta reflexión se acerca a uno de los postulados más emblemáticos de Ricardo Piglia: “el problema no es tanto que una obra sea o no de vanguardia: lo fundamental para un escritor es que el público y la crítica sean de vanguardia"38. En esta dirección, la participación del lector es ampliamente significativa cuando comienza a leer de otro modo, rompiendo las maneras tradicionales, tal como el propio Piglia, en su faceta de lector, hace con Los adioses de Onetti, nouvelle que ubica dentro del código de la literatura fantástica:

\footnotetext{
No pretendo aventurar una interpretación de Los adioses. Eso no es lo que me interesa. Lo que quiero es encontrar los índices que me permitan reconstruir esa historia que no ha sido narrada. En la nouvelle, es el lector quien tiene que narrar. Así que voy a decirles rápidamente cuál es mi relato de esta historia, que es un relato de fantasmas, yo creo que es un relato de fantasmas y que en realidad este hombre está allí porque busca el fantasma de la mujer que ha muerto, a la cual ha amado, y se encierra en la casa de las portuguesas para estar con el fantasma de esa mujer que él amó en el pasado $^{39}$.
}

\footnotetext{
${ }^{37}$ Harry Belevan, op. cit., p. 121.

${ }^{38}$ Ricardo Piglia, "Notas sobre literatura en un Diario", Formas breves, op. cit., p. 87.

39 Ricardo Piglia, "Secreto y narración. Tesis sobre la nouvelle", en Eduardo Becerra (ed.), El arquero inmóvil. Nuevas poéticas sobre el cuento, Páginas de Espuma, Madrid, 2006, p. 202.
} 
Como puede apreciarse, la lectura desviada que puede hacerse de un texto determinado, comprendido de acuerdo con una tradición (la lectura realista de Los adioses sería el modo convencional, en este caso), se rompe cuando logra ser leído desde un contexto distinto. Las influyentes y polémicas lecturas que Ricardo Piglia ha llevado a cabo siempre han terminado por influir en la crítica literaria, que por otro lado intenta llevar las reflexiones del escritor argentino al estudio de su corpus narrativo. En este sentido, resulta clara la presencia de Onetti en la obra pigliana: La ciudad ausente también gira en torno de una mujer que se ha perdido; solo se le recupera mediante la invención fantástica: la máquina creada por Russo y Macedonio la devuelve de la muerte, pero su función principal ya no es consolar a este último, sino garantizar la sobrevivencia de la literatura mediante la narración y la conservación de los relatos sociales. En las dos primeras novelas de Piglia, Respiración artificial y La ciudad ausente, así como en la nouvelle "Encuentro en SaintNazaire", los relatos múltiples que cruzan esos textos pueden ser leídos como materiales residuales que han sobrevivido al tiempo y al poder estatal; los elementos fantásticos que contienen (en menor y mayor medida) funcionan como un dispositivo que intenta romper los relatos realistas del Estado: ahí reside el aparato estético-revolucionario de su poética.

\section{Una poética gemela}

En el cuento que abre Lugar, Juan José Saer le propone a sus lectores, de modo implícito, un pacto donde acepten y asuman que lo que están leyendo pueda ser aceptado, a pesar de que el suceso narrado sea inverosímil en nuestra "realidad". El breve texto se llama "La conferencia"; su argumento es parecido al motivo de "La rosa de Paracelso" de Borges: un viejo conferenciante está por dar una plática "en una de las salas de la Real Academia de 
Ciencias de Bruselas" ${ }^{40}$; antes de hacerlo, decide contarle al auditorio el sueño que tuvo en los momentos previos de emprender el camino al sitio de la conferencia. El científico explica que acostumbra dormir antes de hablar en público y a continuación relata:

\begin{abstract}
Tres personas diferentes fotografiaban rinocerontes. Eran tres imágenes sucesivas, pero el método que empleaban para sacar la fotografía era el mismo: se internaban en el río hasta la cintura, y fotografiaban de esa manera al rinoceronte, que se encontraba a unos metros de distancia, en el agua. Se trataba de rinocerontes, no de hipopótamos. El último de los fotógrafos era un poeta amigo mío (al que no conozco personalmente). Era mi amigo en el sueño. Este poeta, de fama universal, me explicaba en detalle el procedimiento que se emplea habitualmente para fotografiar rinocerontes. Y, en nombre de nuestra vieja amistad, me regalaba la fotografía que acababa de sacar ${ }^{41}$.
\end{abstract}

A continuación, el hombre aclara que quizá todos piensen que se haya tratado de un sueño trivial, pero afirma: “Aquí tengo la prueba, dijo, y alzó la mano mostrando al público la fotografía en colores de un rinoceronte en un río africano, todavía húmeda, a causa sin duda de la proximidad del agua o del reciente revelado",42.

Como en buena parte de los relatos pertenecientes al género fantástico, Saer permite que los receptores explícitos e implícitos del relato del conferencista conozcan la prueba con la cual se intenta despejar toda duda del lugar donde se encontraba el narrador, minutos antes de dar una conferencia en Bruselas. Tratándose del texto que abre Lugar, y que pareciera, inclusive, un prólogo, debido a que el relato está escrito en letras cursivas en su totalidad, puede hablarse de un pacto que Saer establece con los lectores: si quieren aceptar los relatos que se cuentan (otro texto, "En línea", posee una estructura metaficcional que funciona como un procedimiento del género fantástico), debe ser con la intención de dejar a

\footnotetext{
${ }^{40}$ Juan José Saer, "La conferencia", Lugar, Seix Barral, Buenos Aires, 2006, p. 9.

${ }^{41}$ Ibidem.

${ }^{42}$ Ibid., p. 10.
} 
un lado las viejas nociones de "ficción” y "realidad", opuestas entre sí, y, simplemente, leer.

En este sentido, a Piglia tampoco le preocupa la supuesta "veracidad" que un relato pueda tener desde el punto de vista de los lectores, pues eso es parte de un problema que se resolvió desde la época de los primeros cuentos de Borges ${ }^{43}$. En entrevista, el escritor argentino afirma, a propósito de Steve Ratliff, personaje imaginario de "Prisión perpetua", creado, en parte, para anular toda frontera rígida entre realismo y ficción: "uno puede decir que la figura de Ratliff la podemos entender como alguien que ha tenido importancia en mi formación: lo que me motivó a trabajar sobre Ratliff es la idea de que él condensa para mí la literatura norteamericana, de modo que no importa si el personaje es real o no"

En la literatura fantástica, resulta necesario establecer los límites entre lo que se considera "literatura realista" en oposición a aquel género, sobre todo porque esos límites también sugieren una posición poética y política; como señala Laurette Godinas a propósito

\footnotetext{
${ }^{43}$ Cabe señalar que, en la línea de lo fantástico en el Río de la Plata, los textos que podemos considerar como fantásticos en Piglia están mucho más cerca de las poéticas de Borges, Macedonio Fernández y Saer, que de Julio Cortázar, quien en libros como Bestiario elabora una poética de lo fantástico estrechamente vinculada al surrealismo. El relato homónimo que cierra el volumen, así como un estudio revelador de lo anterior, lo demuestran (Cfr. Julio Cortázar, Cuentos completos 1, Alfaguara, México, 2001, y Jaime Alazraki, En busca del unicornio: Los cuentos de Julio Cortázar. Elementos para una poética de lo neofantástico, Gredos, Madrid, 1983). Aunque Piglia establece cierta relación menor con la literatura cortazariana, no es esta la que resulta decisiva en su poética de lo fantástico.

${ }^{44}$ Infra, p. 175. En la entrevista, resulta de importancia para nuestro tema la respuesta sobre la opinión de Roberto Bolaño a propósito de "Un cadáver sobre la ciudad", de Formas breves, donde se narra que el cuerpo de Arlt no cabía por la puerta y lo sacaron por la ventana. Como una queja, Bolaño afirma que lo anterior es falso; en mi entrevista, Piglia afirma: "me parece que la literatura es un campo de experimentación de esa relación; entonces, todas esas historias que estamos recuperando acá, si existe o no existió, si la foto existió o no existió, en fin, todo eso, me parece que hace el intento de pedirle a la ficción una respuesta que la fícción no puede dar, porque la ficción es esa indeterminación en el sentido de que nos produce un efecto que es el efecto de suspenso, yo diría... esto que estoy leyendo sucedió o no sucedió, sucedió en un sentido, ¿no? Desde luego, más allá de la existencia de las fotos, se trataba de una metáfora; fuera real o no la foto, es una metáfora decir que Arlt sigue ahí, insepulto todavía y en el aire" (Infra, pp. 179-180). Para conocer con detalle la opinión de Roberto Bolaño sobre "Un cadáver sobre la ciudad", la relación Piglia-Arlt y la trampa en la que el escritor chileno cae, cfr. "Derivas de la pesada", Entre paréntesis, Anagrama, Barcelona, 2004 (Argumentos, 316). Por su parte, González Álvarez asocia el relato del cadáver de Arlt con los problemas para sacar el cuerpo de Felisberto Hernández, lo que resuelve el misterio que Bolaño comenta (José Manuel González Álvarez, op. cit., pp. 89-90).
} 
de la obra literaria de Piglia, "la lengua es el vehículo de la ideología"45, lo que significa que su tratamiento implica una toma de posición no sólo estética, sino también social. Por eso, Piglia busca insertarse en la tradición literaria argentina que tiene en Borges a uno de sus grandes renovadores (y el que contribuye, más que nadie en la zona porteña, a reivindicar el género fantástico), pero que también tiene en Roberto Arlt a uno de los escritores más influyentes, combativos y de gran actualidad ${ }^{46}$.

Tal inserción en la tradición literaria argentina también tiene nexos con el género fantástico. Para Piglia, la literatura fantástica es un concepto "construido por Borges para enfrentar la dominante de la literatura realista, para establecer un espacio en el que hacer posible una escritura que no fuera leída con los canones o criterios de la literatura realista" ${ }^{47}$. Borges desarrolla lo que Macedonio había empezado a manifestar en su Museo de la Novela de la Eterna ${ }^{48}$, lo que permite establecer una relación con La ciudad ausente a partir de estos preceptos y de esta ruptura con una literatura nacional, oficial y estancada, como lo era el realismo de las primeras décadas del siglo XX.

Como los lectores y el público de "La conferencia" de Saer (a diferencia del malogrado discípulo de Paracelso, que necesita y exige una prueba de lo fantástico, lo que le niega el maestro para que, una vez que aquel se haya ido, haga surgir la rosa de sus cenizas ${ }^{49}$ ), los lectores de Piglia deben aceptar la pertinencia de los acontecimientos narrados (como el

\footnotetext{
${ }^{45}$ Laurette Godinas, "Entre política y tradición: Ricardo Piglia, la filología y el lenguaje", en Rose Corral (ed.), Entre ficción y reflexión. Juan José y Ricardo Piglia, El Colegio de México, México, 2007, p. 191.

${ }^{46}$ Al final de la presentación de su libro Roberto Arlt: una poética de la disonancia, en la sala Alfonso Reyes de El Colegio de México, Rose Corral afirmó que, en otra presentación, en Buenos Aires, a propósito de otro libro de Roberto Arlt (El paisaje en las nubes), Piglia sostuvo que Arlt es un escritor mucho más moderno que bastantes escritores actuales de la Argentina.

${ }^{47}$ Infra, p. 183.

48 "Borges le da un sentido totalmente conceptual, completamente conceptual más que temático, al género, y construye, alrededor del género, primero, una reacción frente al realismo, y, por lo tanto, una poética de la narración, que es una de las grandes poéticas que se han construido no solo en América Latina. Ahí es donde él es muy deudor de Macedonio, que es el primero que empieza a construir sus hipótesis en contra del realismo, como camino central de la literatura, no sólo en lengua castellana" (Infra, pp. 183-184).

${ }^{49}$ Jorge Luis Borges, "La rosa de Paracelso", La memoria de Shakespeare, Alianza Editorial, Madrid, 1998.
} 
destinatario de las cartas del estudiante argentino en Respiración artificial, y al que misteriosamente le ocurre lo que lee en la novela de Saul Bellow y en el cuento de Donald Barthelme), ya que los temas y sus procedimientos cumplen varias funciones en la poética del autor argentino, en el contexto de una tradición literaria que adquiere un carácter revolucionario. 


\title{
I. TRANSFORMANDO LOS MODOS DE LEER Y ESCRIBIR: RESPIRACIÓN ARTIFICIAL Y LOS TEXTOS DEL PASADO
}

\subsection{La recepción de la novela}

\author{
Así que esta novela se parece más a la vida \\ que la "novela mala" o realista, es decir la novela correcta. \\ MACEDONIO FERNÁNDEZ, Museo de la Novela de la Eterna
}

Primer postulado de Respiración artificial: la ficción antecede a la realidad. JUAN VILLORO, "La máquina desnuda: sobre Respiración artificial"

Respiración artificial propone un sistema de lectura y de recepción que podría interpretarse en varios niveles de la poética de Ricardo Piglia; entre estos destaca el empleo de la metaficción, que permite comprender la estructura, el estilo y la función estética de la novela como una forma de resistencia social, en el contexto de la dictadura militar de finales de los años setenta y principios de los ochenta. La lectura de obras de ficción, documentos históricos y cartas personales que hacen los personajes de esta novela puede ser, en cierto modo, una clave para interpretar algunos momentos de la novela: así, el metarrelato es una breve narración que implícitamente alude al sentido de unidad de la novela y a la poética del escritor argentino ${ }^{50}$. Cuando uno de esos niveles narrativos sale de su propio espacio y penetra en el que lo enmarca, surge el carácter fantástico de la obra.

\footnotetext{
${ }^{50}$ Siguiendo a Genette en su definición de metarrelato, Lucien Dällenbach lo describe como un "segmento textual apoyado por un narrador interno a quien autor o narrador ceden temporalmente su sitio, liberándose pues de su responsabilidad de conductores de relato" (op. cit., p. 66). La intención de colocar a varios narradores en Respiración artificial tiene relación con la estructura de la novela, que se despliega en diversos niveles narrativos. Emilio Renzi es el primero de una serie de narradores. Otro, de gran importancia, es Enrique Ossorio, que aparece situado en el tiempo de la novela en el siglo XIX. De este modo, Piglia establece fronteras espaciales y temporales que poco a poco va difuminando mediante la aparición del fenómeno fantástico.
} 
La primera novela de Piglia ha sido leída y analizada dentro de la tradición de una crítica literaria que tiende a explorar sus aspectos sociales. La resistencia intelectual frente a la política controlada por los sistemas gubernamentales es un aspecto muy estudiado desde los primeros años de su aparición ${ }^{51}$. En el contexto de la última dictadura militar en Argentina (1976-1983), Respiración artificial fue leída más como una novela de resistencia política contra los embates de los militares que como una obra de lo fantástico.

La forma y el estilo de la novela se caracterizan por la representación de distintos géneros discursivos, como el epistolar, el diario (que todo lo abarca y contiene: notas, apuntes, reflexiones, epígrafes, borradores, viajes, conversaciones, etc.), la cita, el diálogo, la narración en primera y tercera personas. Al ser una novela cuyo discurso es más cercano a la exposición de ideas, la narración de acciones tiene una importancia menor; la novela navega en las aguas de las ideas y de los diálogos. Por eso, Juan José Saer califica esta obra como "novela-ensayo" en una "época en la que en Argentina estaba prohibido $\operatorname{argumentar"}, 52$; es decir, que su característica central es el desarrollo de una posición crítica

\footnotetext{
${ }^{51}$ Para la revisión del tema de la resistencia social en las novelas de Piglia, especialmente en Respiración artificial, cfr. Jorgelina Corbatta, "Narrativas de la Guerra Sucia: Ricardo Piglia", Narrativas de la Guerra Sucia en Argentina (Piglia, Saer, Valenzuela, Puig), Corregidor, Buenos Aires, 1999, pp. 45-64; Isabel Quintana, "Experiencia, historia y literatura en la obra de Ricardo Piglia", Figuras de la experiencia en el fin de siglo. Cristina Peri Rossi, Ricardo Piglia, Juan José Saer, Silviano Santiago, Beatriz Viterbo, Rosario, 2001 (Tesis / Ensayo), pp. 67-117; Francine Masiello, "La Argentina durante el proceso: las múltiples resistencias de la cultura", en Daniel Balderston, David William Foster y otros, La narrativa argentina durante el proceso militar, Alianza Editorial / Institute for the Study of Ideologies \& Literature, Buenos Aires-Madrid (Alianza Ensayo); Marta Morello-Frosch, "Significación e historia en Respiración artificial", en Jorge Fornet (ed.), Ricardo Piglia, Casa de las Américas, Bogotá, 2000, pp. 149-162. Por otro lado, Rita De Grandis explora el tema de la resistencia social y su relación con las formas narrativas en la obra narrativa de Piglia en Polémica y estrategias narrativas en América Latina. José María Arguedas, Mario Vargas Llosa, Rodolfo Walsh, Ricardo Piglia, Beatriz Viterbo Editora, Rosario, 1993 (Tesis), pp. 121-148. En su relación con la metaficción y el discurso narrativo, el trabajo de De Grandis es el más cercano al presente estudio, aunque no aborda la temática de la literatura fantástica en la obra de Piglia, aunque sí atiende la autorreferencialidad.

52 Juan José Saer, "Historia y novela, política y policía", en Adriana Rodríguez Pérsico (comp.), Ricardo Piglia: una poética sin límites, op. cit., p. 272. Este ensayo es fundamental para la actual recepción de la novela de Piglia. Lejos ya de los años de la dictadura militar, el autor de El entenado propone que Respiración... se lea, ahora, no como novela histórica o como una novela únicamente política, sino como novela, sencillamente. En su breve ensayo, Saer pide que la lectura actual de esta novela sea renovadora:
} 
y filosófica sobre dos aspectos que son recurrentes en la poética de Piglia: la literatura como un modo de resistencia y la tradición literaria como un lugar revisitado, criticado y cuestionado, desde el que se lanza un proyecto poético.

Estas visiones de lo real, que también abarcan la crítica social a los regímenes dictatoriales, como el de Hitler en Europa y el de los militares en la Argentina de los años setenta y ochenta, han relegado la aparición de ciertas referencias que, de ser analizadas con mayor detenimiento, pueden arrojar cierta luz no sólo al mismo objeto de estudio, es decir, a los modos en que debe crearse una resistencia a los gobiernos dictatoriales, sino también a los modos de leer dentro del cruce de diversas tradiciones literarias y géneros. De esta manera, la novela alude a su propia concepción mediante la interpolación de citas textuales y ocultas, así como de otras referencias que, insertadas dentro de un contexto específico, logran darle una nueva significación. El recurso de la metaficción permite leer la novela de otro modo: el metarrelato se encuentra, aparentemente, en un sitio ajeno a la historia principal; sin embargo, ambos relatos (el que enmarca y el que se encuentra enmarcado) están más unidos de lo que a simple vista se lee. En cuanto al empleo de la intertextualidad como una práctica constante en la literatura hispanoamericana y como una característica propia de la escritura de Ricardo Piglia, las referencias a otras obras y otros escritores deben ser estudiadas a propósito de su posición literaria, en el contexto de una tradición que busca renovarse e identificar el estado actual de la literatura. Así, en algunas citas, alusiones, y pastiches de Respiración... puede verse, implícitamente, la presencia del

\footnotetext{
"Veinte años más tarde [de la primera edición, en 1980], con el cambio de circunstancias, la posición del libro ha cambiado; su representatividad generacional, política, moral, etc., ha pasado a un segundo plano y podemos decir que, para los lectores de hoy, "sólo" queda la novela" (p. 272). Más que una novela histórica o una novela de resistencia que vea la historia como objeto de representación, conviene que, de acuerdo con Saer, la historia sea tema. En este sentido, las estrategias literarias de Piglia, como la metaficción, el empleo de la intertextualidad y el giro al género fantástico, pueden ser nuevos modos de leer y comprender su poética.
} 
género fantástico, considerado un elemento marginal en la poética del autor argentino pero que cumple con diversas funciones, entre las que destaco la función social.

\subsection{Las cartas del pasado y del porvenir. El planeta de Mr. Sammler y otros [inter]textos}

Al cambiar los modos de leer, la disposición,

el saber previo, cambian los textos del pasado RICARDO PIGLIA, "El escritor como lector"

¿Cómo leer Respiración artificial ${ }^{53}$ ? Si existen varios modos de hacerlo, probablemente alguno se realice a través del análisis de la figura del inquisidor Arocena, cuya aparición es interpretada como una alegoría de la censura y la persecución política en los años de la última dictadura argentina. Este personaje intercepta cartas que, en muchos casos, provienen de los opositores al gobierno militar: marginados, perseguidos políticos, intelectuales, estudiantes, outsiders, son vigilados para saber si realizan labores políticas contrarias al régimen. Marcelo Maggi, tío de Emilio Renzi, se encuentra en esta situación en el momento en que su sobrino irá a visitarlo a Concordia, lugar donde se ha autoexiliado después de un escándalo familiar que lo puso, durante algunos años, en la cárcel. La correspondencia epistolar entre Maggi y Renzi, en la primera parte de la novela, culmina con el anuncio de la llegada de este a Concordia. La aparición de Arocena se relaciona con este suceso.

\footnotetext{
${ }^{53}$ Ricardo Piglia, Respiración artificial, op. cit. En adelante, después de cada cita de esta obra, solo pondré entre paréntesis el número de página.
} 
El tercer y último capítulo de la primera parte de la novela ofrece, de manera desordenada, una serie de fragmentos que corresponden a distintos géneros discursivos y que se entremezclan sin un criterio cronológico. Ahí aparecen las cartas de Enrique Ossorio a sus compatriotas, cuanto ya se encuentra en el exilio, una vez que se ha separado de su cargo de secretario particular del dictador Juan Manuel de Rosas y los opositores tienen serias dudas sobre su verdadera posición política, al encontrarse en una zona ambigua; también pueden leerse otros documentos del mismo personaje, como los fragmentos de su Autobiografía, que ha anunciado en una carta, y algunos apuntes sobre la novela utópica que está escribiendo: 1979. Entre estos párrafos, también se encuentran varias cartas de Maggi y Renzi y otras que están cifradas. Arocena ha podido descodificar algunas. Estos documentos confirman la existencia de la lucha opositora a la Junta militar por parte de quienes resisten dentro y fuera del país. Hay cartas que aparentemente narran hechos cotidianos, pero el método de Arocena consiste en analizar cada una entendiendo que existe un código que siempre oculta un mensaje subversivo. En estas cartas de la vida diaria, se narran acontecimientos fantásticos con múltiples referencias eruditas; uno de los personajes que escribe desde el extranjero posee un nivel cultural que le permite leer, en lengua inglesa, algunas narraciones que, en el contexto de lo que ocurre en la escena política argentina de finales de los setenta y principios de los ochenta, pueden ser interpretadas como una crítica y una posición revolucionaria a los sucesos de sangre y represión; paralelamente, estas narraciones, que son referencias intertextuales de importancia en la novela de Piglia, permiten indagar en su poética en la medida que pueden ser leídas a la luz de una tradición literaria de lo fantástico, pero cuyo discurso se disfraza de novela convencional, o sea, de novela realista. 
En las cartas que Arocena intercepta y lee, se sugiere que el personaje anónimo probablemente es un opositor político que da el nombre de Martín Carranza, estudiante de física en Oxford (p. 101); detrás del hombro del inquisidor, los lectores nos enteramos de lo que el joven escribe cuando le explica a un destinatario identificado como su hermana (aunque probablemente se trate de una mujer de la resistencia en Argentina ${ }^{54}$ ) que algunas escenas de lo que ha estado leyendo en los últimos días, en Estados Unidos, también ocurren en la vida real:

\begin{abstract}
Me ha pasado algo tan raro que te ahorro otras noticias personales. (Aparte de eso, estoy bien: visito museos.) Estaba leyendo una novela de Bellow (Mr. Sammler's Planet) de esto hace casi una semana. La había comprado en un quiosco porque tenía que hacer tiempo mientras me renovaban la visa. Tomé el ómnibus que va por la calle 42 , me senté y empecé a leer. De pronto levanto la cara y veo a un carterista que está robando a una mujer. Era corpulento, llevaba anteojos oscuros con montura de carey, vestía con extraordinaria elegancia. Yo estaba fascinado viéndolo actuar pero de pronto el tipo dio vuelta la cabeza y me miró, casi con placidez, a través del vidrio ahumado de los anteojos; entonces me sobresalté y casi sin querer bajé los ojos y seguí leyendo. Tardé un momento en darme cuenta de que lo que estaba leyendo era exactamente lo que pasaba en el ómnibus. Podés ver la edición de Random House de la novela, página 3. Vas a encontrar la descripción de un tipo corpulento, que usa anteojos oscuros con montura de carey y viste con extraordinaria elegancia, que le roba a una mujer en un ómnibus que va por la calle 42 (pp. 97-98).
\end{abstract}

Esta primera referencia a la literatura estadounidense, en la novela de Piglia, permite el cruce de dos tradiciones literarias antagónicas: la realista y la fantástica. En el primer caso, la mención a la novela de Saul Bellow se enmarca dentro de la tradición del "realismo prolijo de los escritores norteamericanos” (p. 98). El personaje anónimo intenta justificar lo visto pensando en que seguramente Bellow vio, alguna vez, al carterista en esa misma calle

\footnotetext{
${ }^{54}$ En las cartas intercambiadas entre estos personajes que al parecer fingen ser hermanos, ella se refiere a la estancia de él en Londres (p. 93). Por su parte, el personaje masculino escribe desde East River, Nueva York (p. 97), que es el sitio del exilio del personaje decimonónico Enrique Ossorio.
} 
y lo transformó en un personaje novelesco. Sin embargo, la percepción del realismo en la literatura, representada a través de la novela del escritor judío, cobra una nueva significación en el momento en que el personaje anónimo ha visto cómo se reproduce el arte en la vida real: "la naturaleza imita al arte" (p. 98), dice, siguiendo a Wilde, con lo que el efecto fantástico de ver lo que se ha leído le otorga una mayor importancia a la creación literaria que a la vida real y monótona de los seres humanos. La resistencia ante los regímenes totalitarios comienza en la creación literaria: salirse del realismo puro, considerado una estética convencional para Ricardo Piglia (en la línea de Macedonio y Borges), y entrar a la órbita de la literatura fantástica, es un modo de resistencia y denuncia sociales.

La identificación de los procedimientos formales y del estilo, en una novela, tendría un valor escaso si no se tratara de relacionarlos con la lingüística y la semiótica pragmáticas. ¿Cómo funciona un procedimiento literario? El concepto de función, estudiado desde el formalismo ruso y retomado en los acercamientos de la semiótica anglosajona, se emplea para conocer cómo opera un recurso literario. En este sentido, las primeras lecciones que recibe Renzi en la correspondencia con su tío tienen que ver con la ausencia de profundidad en La prolijidad de lo real, la primera novela del alter ego de Piglia. En su descripción poco entusiasta, Emilio señala que su "relato sonaba a una versión más o menos paródica de Onetti. Ninguno de nosotros, de los que estuvimos ahi la noche en que se entrevió por fin, en la entristecida penumbra que siguió a la tarde del entierro, el secreto de esa venganza cultivada durante años..." (p. 16) Por su parte, Maggi no critica que la prosa del sobrino tenga un aire onettiano y unos tonos adquiridos por las lecturas de Faulkner en traducciones de Borges (p. 16), sino que el enigma familiar (del que el propio Marcelo es protagonista) sea hueco y no ofrezca una perspectiva filosófica, historiográfica o estética 
que proponga una renovación literaria que justifique su publicación, más allá del argumento, basado en un chisme de familia. A Marcelo le interesa el procedimiento y sus funciones, junto con la temática, basada en la lucha y la denuncia: por eso, comienza el Bildüngsroman de Renzi, su educación en la resistencia social ${ }^{55}$.

Más allá del estilo basado en la escritura de Onetti y del título de esa primera novela, La prolijidad de lo real, tomado del último verso de un poema de Borges $^{56}$, y que se enlaza con esa frase que dice el estudiante desde Nueva York, "el realismo prolijo de los escritores norteamericanos" (p. 98), el realismo se revierte en las enseñanzas de Maggi (le hereda a Renzi los papeles de Ossorio, entre los que destaca una novela del siglo XIX, en la que ellos aparecen como personajes) y en el descubrimiento de lo fantástico, al duplicarse la experiencia "fuera" de la ficción de la novela de Bellow ${ }^{57}$.

\footnotetext{
${ }^{55}$ De un modo que también podría considerarse alegórico, el predominio formal sobre el "fondo", aspecto que interesaba mucho a Renzi antes de re-conocer a su tío Maggi, puede observarse en el encuentro de aquel con Tardewski, en la segunda parte de la novela. A Emilio le interesaba conocer las anécdotas del exiliado polaco con Joyce, con quien jugó ajedrez. El maestro de los procedimientos narrativos por excelencia, James Joyce, apenas es mencionado por Tardewski; le interesa más hablar sobre Kafka: "Todos nosotros, dijo Tardewski, conocíamos a Proust y a Joyce, pero ¿Kafka? ¿Quién era ese tipo de nombre tan cacofónico? Para ese entonces se habían publicado ya los tres primeros tomos de sus Obras completas y la mayoría de los estudiantes que cursamos ese seminario nos lanzamos, por supuesto, a la lectura del autor de La metamorfosis. Todavía hoy, dijo Tardewski, recuerdo la impresión que me produjo y no creo que jamás otro escritor me haya producido o me vaya a producir el mismo efecto". (p. 179). Más allá de los procedimientos narrativos con los que el autor de Ulysses revolucionó la literatura del siglo XX, el nombre de Kafka está relacionado con el horror humano; por eso, el autor checo es más admirado que el escritor irlandés. La lección de crítica literaria que le da Tardewski a Renzi se centra en los procedimientos artísticos y su conexión con la función social.

${ }^{56}$ Jorge Luis Borges, "La noche que en el Sur lo velaron", Obra poética, 1, Alianza Editorial, Madrid, 1999, p. 107.

${ }^{57}$ Para Laura Demaría, la clave para leer Respiración artificial se encuentra en el título La prolijidad de lo real, ya que Maggi orienta a Renzi sobre el modo en que debe encontrar la verdad y su representación realista en la literatura. Si al final se sabe que Maggi no era un defraudador y su pasado de ladrón queda borrado con las declaraciones absolutorias de quien lo acusó, en todo caso, Marcelo afirma que todo es apócrifo, que sí robó. Prolongar la mentira, lejos de revelarla como tal en el contexto de la publicación de la novela realista de Renzi ("primera novela mala", en términos macedonianos), es un gesto que intenta cruzar la realidad con la ficción, como ocurre en Respiración artificial, "primera novela buena": La prolijidad de lo real, entonces, no es tan real. Se construye, paradójicamente, sobre una mentira [...] En Renzi y en Borges la prolijidad de lo real es una construcción subjetiva" (Laura Demaría, Argentina-s. Ricardo Piglia dialoga con la generación del 37 en la discontinuidad, Corregidor, Buenos Aires, 1999, pp. 24-25). Por su parte, para Juan Villoro, "El título de la novela de Renzi, La prolijidad de lo real, adquiere fuerza magnética: el mundo de los hechos es confuso, incesante, inagotable. Ordenarlo, dotarlo de sentido, es atributo de la imaginación narrativa" (Juan
} 
Al responder a propósito de la relación que existe entre el género fantástico y la función social en su narrativa, Ricardo Piglia afirma: "no debemos circunscribir la intervención de la literatura en lo real solamente en términos de la reproducción fiel de los modos en que la sociedad funciona dentro de la literatura realista, sino que se pueden construir mundos alternativos que son críticas al presente y que eso es una gran tradición, también, de Swift para abajo"

La crítica social que ejerce este escritor en sus textos narrativos forma parte de una función que permite reflexionar sobre el estado de los problemas políticos y sociales. Asimismo, y de manera paralela, el empleo de la metaficción como procedimiento literario permite la entrada de lo fantástico: siguiendo esta poética, instalada en el ámbito rioplatense desde la aparición de los cuentos de Borges y el análisis que Ana María Barrenechea llevó a cabo $^{59}$, en la narrativa de Piglia hay un desajuste de la realidad en el momento en el que dos niveles narrativos se cruzan. En Respiración artificial, novela considerada realista por la mayor parte de los críticos, la serie de cartas escritas en Estados Unidos que llega a la nación argentina cuestiona y transgrede la realidad. Lo anterior puede ser percibido, de modo claro, en el cruce que se produce entre la novela de Bellow y Respiración artificial: las cartas que lee el censor Arocena permiten poner, en un mismo plano, la práctica de la intertextualidad, la metaficción y lo fantástico.

Las referencias intertextuales a El planeta de Mr. Sammler, en el marco de la narración metaficcional, a través del relato epistolar, permiten interpretar esta novela bajo la forma de

Villoro, "La máquina desnuda. Sobre Respiración artificial", Biblioteca Virtual Miguel de Cervantes, www.cervantesvirtual.com/servlet/SirveObras/bameric/07038330969692039647857/p0000001.htm\#I_0, página consultada el 30 de junio de 2010.

${ }_{58}^{5}$ Infra, p. 185.

${ }^{59}$ Cfr. Ana María Barrenechea, "La expresión de la irrealidad en la obra de Jorge Luis Borges", en Ana María Barrenechea y Emma Susana Speratti Piñero, La literatura fantástica en Argentina, Imprenta Universitaria, UNAM, México, 1957. 
la duplicidad y el tema del doble. Al fracasar en su intento de denunciar al ladrón del autobús, Mr. Sammler "se obstinó en repetir la experiencia"60; la frase anterior bien podría ser repetida por algún personaje pigliano, como Renzi, Maggi o Tardewski.

Las acciones narradas en la carta del personaje que lee a Bellow invitan a cotejar la historia con su hipotexto: en las primeras cincuenta páginas de El planeta de Mr. Sammler (aunque en realidad la presencia del ladrón negro es un leitmotiv) el protagonista observa, en distintos momentos, el trabajo del carterista, en medio de una sensación de duplicación infinita. En la carta del personaje de Respiración artificial, la historia de Sammler y el ladrón negro se condensa en unos cuantos párrafos; en algunas frases, el recurso de la paráfrasis permite la duplicación de lo que ocurre: Sammler repite la experiencia, la duplica, y el personaje pigliano hace lo mismo al citar y parafrasear al narrador de Bellow. Cuando descubre al ladrón, este se encontraba robando el contenido de la bolsa de una mujer y voltea rápidamente para identificar al que lo observa; en la novela de Bellow, Sammler es descubierto por el carterista cuando asalta a otro anciano: "Fue en ese momento cuando, con un rápido movimiento de la cabeza, vio a Mr. Sammler, que, mientras el negro lo miraba, seguía sintiendo rápidas corrientes en su corazón" ${ }^{\text {,61 }}$. En ambos casos, los personajes se desentienden de lo que han visto, como una manera de sobrevivir ante el peligro.

La carta que contiene esta y otras referencias a la literatura del realismo estadounidense duplica y deforma la realidad, en un intento de resistir la represión policial, buscando nuevos recursos para pasar los filtros de la censura. Como si fuese un censor de la Inquisición en tiempos de Cervantes, Arocena cumple la función de analizar y descifrar la

\footnotetext{
${ }^{60}$ Saul Bellow, El planeta de Mr. Sammler, trad. de Rafael Vázquez Zamora, Random House Mondadori, Barcelona, 2005 (DeBolsillo, 584), p. 13.

${ }^{61}$ Ibid., p. 50.
} 
correspondencia entre los sospechosos de subversión. Así como el escritor Ricardo Piglia buscó "hablar de lo indecible" (p. 214) en Respiración artificial, como un modo de sobrevivir al silencio impuesto por la dictadura ${ }^{62}$, el personaje que escribe las cartas desde los Estados Unidos intenta llegar a sus compañeros de lucha mediante la escritura de referencias cruzadas, prácticas y juegos intertextuales, citas veladas, alusiones y pistas ocultas o falsas ${ }^{63}$.

Además de la mención a Mr. Sammler's Planet, el estudiante de Oxford que supuestamente escribe la carta, Martín Carranza, ofrece otras pistas para la interpretación de su texto. Siguiendo un procedimiento típicamente borgiano, que consiste en mezclar referencias verdaderas con autores u obras de carácter apócrifo o imaginario, Piglia, a través de su narrador-personaje, y en el marco de una carta que relata una serie de sucesos fantásticos, enmarcados en un ambiente realista, propio del género de las novelas que ha leído, cita dos textos más: como en el caso de la novela de Bellow, el narrador-remitente

\footnotetext{
${ }^{62}$ La última parte del diálogo entre Renzi y Tardewski, con el que finaliza la novela, trata sobre el encuentro entre Hitler y Kafka. En medio del horror provocado por la desaparición de miles de personas, la censura del régimen militar y la persecución sistemática a los opositores, la metáfora sobre el encuentro entre el escritor checo y el dictador alemán cumple una función intertextual y, simultáneamente, política: Kafka escribió sobre el horror del mundo y su voz sólo calló con su muerte; el silencio que el Estado trata de imponer a sus ciudadanos puede evitarse mediante los juegos del lenguaje y sus prácticas mortales: Kafka es un artista del horror: "Alambre de púas: el equilibrista camina, descalzo, solo allá arriba y trata de ver si es posible decir algo sobre lo que está del otro lado" (p. 215). ¿Cómo escribir en tiempos de horror y persecución política? En parte, Piglia responde a esta pregunta implícita con Respiración artificial, empleando la propia literatura (los juegos metaliterarios) como recurso de la resistencia social.

${ }^{63}$ Lo anterior es, justamente, lo que Laurette Godinas pone de manifiesto en su artículo sobre "La secreta sociedad": ubicando la creación literaria al lado de la resistencia política, la crítica señala la relación entre Los siete locos, "Tlön, Uqbar, Orbis Tertius" (ese gran cuento fantástico de Borges) y la primera novela de Piglia: "[...] Respiración artificial, novela fragmentaria, hecha de citas, documentos escritos y conversaciones, está articulada no directamente en torno a una sociedad secreta sino al archivo de Enrique Ossorio, un traidor de Rosas, sobre el que el historiador Maggi está trabajando en Concordia. La elección del archivo y del tema histórico no es ninguna casualidad: ¿acaso no dice Maggi en una de sus cartas, invirtiendo la frase que Joyce pone en la boca de Stephen Dedalus: La historia es el único lugar donde consigo aliviarme de esta pesadilla de la que trato de despertar?" Así, la literatura se convierte en un espacio de resistencia: las trampas del escritor (en los casos de Godinas: Arlt, Borges y Piglia) funcionan para evitar la censura y la persecución, al mismo tiempo de que logran hacer llegar con eficacia el mensaje a los lectores (Cfr. Laurette Godinas, "La secreta sociedad: Arlt, Borges y Piglia", op. cit., p. 65).
} 
ofrece datos bibliográficos para la segunda referencia: después de presenciar una escena que ya ha leído, afirma: "Vine a casa y estuve un rato dando vueltas hasta encontrar el libro de Donald Barthelme Come back, Dr. Caligari: allí hay un cuento, podés verlo, se llama “Movie” (pág. 176, edición Scribner's, 1970)”. (p. 99). La duplicación de lo leído en la realidad refuerza la escena descrita anteriormente, cuando en un ómnibus se topa con el ladrón de raza negra que roba a los pasajeros.

En los dos casos mencionados, el narrador ofrece pistas bibliográficas que pueden ser rastreadas: en el caso de la novela de Saul Bellow, la traducción española respalda las palabras de la carta, aceptándose la referencia como verdadera, si bien los acontecimientos relatados en la carta están enmarcadas por la duda, de filiación fantástica. Sin embargo, en el caso de la tercera referencia, Piglia ha dado un giro borgiano:

\footnotetext{
Los acontecimientos se reproducen exactamente. Por eso traté de hacer la prueba. Tomé un libro al azar (An accidental man, de Grace Paley) y lo abrí. En el Central Park, una chica vestida de celeste juega con un aro y canta Some of these days. You'll miss me honey. Un chico viene de patinar en el lago. Lleva los patines sobre el hombro, atados con una correa. Se ponen a conversar. (Hi, Raquel, how 're you do, etc.) En un costado una mujer se está besando con un viejo, la chica los ve y sin saber por qué tiene ganas de llorar. Es casi el atardecer, hay como una luz blanda y sucia. Salí a la calle, tomé el subterráneo y me bajé en la 8th. y 81. Crucé la avenida y entré en el parque; me orienté por el lago. Busqué un banco y me senté. Todo estaba quieto. De pronto vi a la chica sobre el camino de grava, vestida de celeste, jugando con un aro y cantando Some of these days. El chico venía caminando desde el lago, con los patines atados con una correa, en el hombro. En un costado una mujer se besa con un viejo y la chica, mientras canta, trata de no llorar (pp. 99-100).
}

Esta tercera y última referencia literaria, que se mezcla con los acontecimientos de la vida cotidiana, posee una diferencia con respecto a las anteriores: Carranza ya no ofrece a su destinatario la referencia bibliográfica completa, escribiendo el nombre de la editorial ni el número de página correspondiente; sencillamente, describe la escena de la novela 
mencionada y, luego de narrar por duplicado lo que ha leído y visto, cierra su carta estableciendo ese cruce entre lo real y lo imaginario, en el que se ha [re]producido el elemento fantástico. Sin embargo, el giro borgiano se produce, más que en lo fantástico, en la atribución falseada: An Accidental Man no es una novela de Grace Paley, escritora de origen estadounidense nacida en New York, sino de Iris Murdoch, de origen inglés. En este momento, el lector asiste a un catálogo de alusiones desviadas: Piglia le atribuye falsamente esta novela a Paley, ocultando el nombre de Murdoch. Este procedimiento es característico de la narrativa de Borges, pero en la novela de Piglia funciona con un propósito político y social, doblemente construido a partir del tema de la resistencia social de los personajes de Respiración artificial, tomando en cuenta a Maggi y al remitente Carranza (no es gratuito que Arocena lea la carta de este seguida de los textos de Renzi a su tío), y de la poética de Piglia, poniendo a funcionar la maquinaria de la creación literaria y sus juegos metalingüísticos y metaliterarios para que la censura no capte el código antidictatorial.

En este sentido, aunque Arocena no sea un buen lector, ya que todo lo intenta observar desde el complot y todo lo interpreta desde un enfoque realista y gubernamental, tiene una clave que, en su lectura paranoica, lee de un modo correcto, aunque sea parcialmente. En la novela de Murdoch, las acciones no se llevan a cabo en Nueva York ni en ninguna parte de los Estados Unidos, sino en Londres y Oxford. Ahí se encuentra parte de las referencias ocultas y las pistas falsas que el estudiante de Oxford, Martín Carranza, ofrece a sus camaradas en el exilio: por eso, Central Park no es el escenario donde se llevan a cabo las acciones que el narrador ve reproducidas, ni se alude a la calle 8 de Nueva York; inclusive, en toda la novela no existe una escena donde una mujer llore al contemplar el beso de un 
viejo con una joven, ni existe un personaje que se llame Raquel ${ }^{64}$. Todo esto indica que se trata de la referencia codificada por parte de Carranza para que la censura no descubra los datos ocultos. Pero Arocena, al parecer, llega parcialmente al mensaje oculto.

A pesar de lo anterior, y aunque Murdoch no pertenezca al "realismo prolijo de la literatura estadounidense", sí pertenece a un realismo parecido, propio de la literatura realista británica del siglo XX. Esta novela de 525 páginas [en la traducción] tiene como tema central el amor, visto desde una perspectiva que intenta unirse a la existencia desdichada de los seres humanos. Aunque esta obra no mantiene una cercanía temática con Respiración artificial, a diferencia de El planeta de Mr. Sammler, existen varios paralelismos: un personaje nacido en Inglaterra pero nacionalizado estadounidense viaja a Oxford para estudiar Historia e intentar conseguir un empleo en el College; la crítica antibelicista en tiempos de la Guerra de Vietnam (la primera edición de An Accidental... es de 1971) que se relaciona con la Segunda Guerra Mundial, analizada por los personajes de Piglia y Bellow; el silencio y la pasividad ante la escena de un asesinato, visto por uno de los personajes, de manera semejante a lo que Sammler presencia y a los sucesos de sangre en la dictadura argentina. Estos paralelismos permiten establecer una línea temática; sin embargo, una diferencia con la novela de Piglia es que ahí se intenta salir de la lectura convencional y de la simple descripción prolija de sucesos relatados en un tono realista.

La obra de Murdoch podría ser definida como una muy tardía novela sentimental, de estilo convencional, que no ofrece ningún aporte a la literatura de su tiempo. Es probable que, por estas razones, Piglia la agregue a la lista de obras descritas por su personaje Carranza. Reproducir las escenas en la "realidad" del exilio de un estudiante de Oxford en

\footnotetext{
${ }^{64}$ Iris Murdoch, Un hombre, si acaso [An Accidental Man], trad. de Antonio Bonanno, Sudamericana, Buenos Aires, 1975.
} 
Nueva York marca, de antemano, una ruptura con cierta tradición que, desde los tiempos de Macedonio Fernández, trataba de combatirse en la literatura argentina por representar lo nacional y oficial.

En esa carta de la novela de Piglia y en la narración de Saul Bellow, la calle 42 es el escenario o el espacio donde ocurren los robos. Esta cifra (en el doble sentido borgiano) es una de las pistas que Arocena rastrea para descifrar el contenido real del mensaje de la misiva: "No hay novedades. Espero el contacto. Me quedaré en el hotel Central Park, 8th. y 42. Broadway. Si no hay noticias antes del 10, seguiré las instrucciones 9.8. Si hay dificultades y tengo que volver, espero un telegrama. Que diga: Felicidades, Raquel" (p. 100). Además de este mensaje, Arocena cree que puede haber otro mensaje, oculto, codificado dentro del primero que ha descifrado. Poco después encuentra otro: "Raquel llega a Ezeiza el 10, vuelo 22.03” (p. 101). Después de este segundo mensaje, Arocena, al parecer, cae en una especie de paranoia textual y por momentos parece que va a perderse en las pistas falsas. El lector implícito, que en cierto modo y parcialmente es representado por el inquisidor, también comienza a naufragar en ese mar de citas y códigos. La propuesta fantástica emerge en el momento en el que la duda y la confusión de lo leído, de lo que se entendería en términos pragmáticos por ficticio y ficcional, se cruza con lo real. Al lector real le corresponde aceptar como cierta la anécdota que narra el exiliado en Estados Unidos, ya que se encuentra enmarcada dentro de una carta con uno o dos mensajes cifrados. La duda es tal en el lector real y en el lector imaginario, Arocena, que inclusive comenta: "Bastante imaginativo el pibe [...] Lo único que falta es que ahora se dediquen a la literatura fantástica" (p. 101). En su mundo represivo, Arocena no acepta ninguna 
interpretación que no sea realista, fiel al discurso del Estado para el que trabaja. Por eso, la literatura de Piglia sugiere una salida de lo convencional:

\begin{abstract}
Hay una serie de contra-relatos estatales, historia de resistencia y oposición. Hay versiones que resisten estas versiones. Quiero decir que a estos relatos del Estado se le contraponen otros relatos que circulan en la sociedad. Un contra-rumor diría yo de pequeñas historias, ficciones anónimas, micro-relatos, testimonios que se intercalan y circulan. A menudo he pensado que esos relatos sociales son el contexto mayor de la literatura. La novela fija esas pequeñas tramas, las reproduce y las transforma. La literatura trabaja lo social como algo ya narrado ${ }^{65}$.
\end{abstract}

La anécdota que se narra en la carta, como un micro-relato o una breve ficción anónima, es, en sí misma, ya es un discurso imaginario ("imaginativo" llama Arocena al autor de la carta) y, por lo tanto, puede salirse de la tradición narrativa convencional para romper las fronteras del texto y la situación política para mostrar cómo se pueden ejecutar actos de resistencia social desde la creación poética. La unión de dos niveles narrativos, como se observa en algunos de los grandes cuentos metaficcionales fantásticos hispanoamericanos, como "Tlön, Uqbar, Orbis Tertius" de Borges, "Continuidad de los parques" de Julio Cortázar, "La fiesta brava" de José Emilio Pacheco, presenta, además de un gran efecto de lo fantástico (pues el marco de los personajes en el que leen o escriben los desborda), una sutil crítica social: la del mundo fascista en Tlön, los peligros de la recepción realista en “Continuidad...", la desaparición del escritor fracasado que ha perdido, paradójicamente, su lugar en el mundo de la "realidad" en "La fiesta brava". De este modo, la ficción en general y la literatura fantástica en particular son un sitio de resistencia ante los discursos estatales. La evasión de la política y de la situación social ya no es considerada un elemento

\footnotetext{
${ }^{65}$ Ricardo Piglia, Tres propuestas para el próximo milenio (y cinco dificultades), FCE, Buenos Aires-México, 2001, (C. P., 607), p. 25.
} 
característico del género: en los relatos mencionados y en la parte analizada de la novela de Piglia, tomando como hipotexto El planeta de $\mathrm{Mr}$. Sammler, una novela del realismo estadounidense, el género se propone cambiar la realidad mediante la lucha social y las ideas.

La pista que ofrece Respiración artificial, como una invitación al lector para que coteje la novela de Bellow, permite establecer la relación temática que existe entre ambas narraciones. Publicada en 1970, El planeta de Mr. Sammler ofrece el relato de ciertos acontecimientos en la vida de un intelectual inglés de origen judío, exiliado en los Estados Unidos. Hay un paralelismo entre Artur Sammler y Vladimir Tardewski, el filósofo exiliado de Respiración artificial: no hay que olvidar, por supuesto, que Tardewski representa, además, la figura del escritor polaco Witold Gombrowicz ${ }^{66}$. Ambos personajes extranjeros encuentran refugio en el continente americano: uno en el norte, otro en el sur. Tienen relaciones con Polonia: Tardewski nació ahí; Sammler vivió en Cracovia durante su infancia y primera juventud. Inglaterra también es importante: Sammler nació en ese país y, cuando habla polaco, tiene un acento oxfordiano; Tardewski va a hacer estudios de doctorado en filosofía a Cambridge y habla un español con acento de la Europa central, lo que le otorga un lugar periférico en su nueva patria, como Sammler. A ambos les cambia la vida cuando Hitler invade Europa: Tardewski se encontraba en Varsovia para rastrear el encuentro entre Kafka y el Führer cuando se ve forzado a huir a Argentina; Sammler, por su parte, vivió en el ghetto de Varsovia, sobrevivió a los nazis, se refugió en la tumba familiar de un cementerio (salió, literal y metafóricamente, de la tumba a la vida) y se refugió, por fin, en Estados Unidos. Otro paralelismo: ambos personajes son intelectuales;

\footnotetext{
${ }^{66}$ Para el análisis de la presencia de Gombrowicz en la literatura de Piglia, cfr. Marzena Grzegorczyk, "Discursos desde el margen: Gombrowicz, Piglia y la estética el basurero", Hispamérica, núm. 73, año XXV, 1996, pp. 15-33.
} 
Sammler analiza el mundo desde la filosofía medieval y su formación de periodista y corresponsal internacional; Tardewski fue alumno de Wittgenstein e interpreta el mundo de acuerdo con su experiencia personal y los signos que le ofrece la vida cotidiana: por eso, el encuentro entre Hitler y Kafka es también el anuncio de la instalación del terror en la Argentina a partir del golpe militar de 1976.

Con una diferencia de diez años en su primera publicación, El planeta de Mr. Sammler y Respiración artificial indagan sobre la naturaleza humana en tiempos de represión política y social. La decadencia de la sociedad capitalista, estudiada en la novela de Bellow, se complementa con la representación de los crímenes militares en Argentina en la novela de Piglia. Los dos personajes, intelectuales marginales de dos sociedades capitalistas, miran con ojos escépticos y desilusionados el camino de la humanidad. El Holocausto y su conexión con la existencia humana y el pesimismo son vistos por dos sobrevivientes del terror europeo que se instalan a observar, después, la decadencia en América ${ }^{67}$. Como el conde Trokay, amigo de Tardewski ("He pensado [...] que yo mismo me podría convertir en un museo [...] Bastaría que me instalaran en una habitación en alguno de los palacios, que me rodearan de la decoración adecuada y de la servidumbre que se usaba entonces y yo podría ser un museo viviente de las costumbres y los modales de la antigua Rusia” (pp. 121-122)); como el cyborg anarquista de La ciudad ausente, Rajzarov, amigo de Macedonio Fernández (“[...] se acordaba de un estudiante ruso al que le había estallado una bomba en el cuerpo, porque no había querido matar a una familia inocente $[\ldots]$ cuando estaba por atentar contra el jefe de la policía política en Odessa. Lo había conocido en

\footnotetext{
${ }^{67}$ En una de sus "Notas en un diario", Piglia recupera las obras de Bellow para establecer una relación con el proyecto de ruptura de Roberto Arlt: "El héroe de sus grandes novelas es un intelectual: lo que importa no es cómo la realidad construye la conciencia de los personajes, sino cómo la conciencia de los personajes define y da forma- a la realidad. Herzog [cuyo personaje central, homónimo, es gemelo de Sammler] es el punto más alto en esa línea" (Ricardo Piglia, "Notas en un diario. El oso", Babelia, sup. cult. de El país (Madrid), núm. 1017, 21 de mayo de 2011, p. 23.
} 
Adrogué, años después, envejecido y totalmente desfigurado por la explosión, y era igual a un fantasma" ${ }^{\text {"68 }}$ ); como el soldado japonés que hallaron mucho tiempo después de que la guerra había concluido ("Cuando lo encontraron ya no sabía hablar, sólo repetía el juramento del ejército imperial que lo obligaba a pelear hasta el fin. Ahora es un viejo de noventa años y lo exhiben en un Museo de la Segunda Guerra Mundial, en Hiroshima, vestido con su raído uniforme de oficial del emperador, empuñando un fusil con bayoneta calada y en pose de combate" ${ }^{\circ 9}$ ), Sammler podría pasar, en su vejez, por "una ruina histórica" ${ }^{\text {70 }}$ ante los ojos de parientes y amigos; este sobreviviente del genocidio se ve a sí mismo como una reliquia viviente debido a su trágica experiencia. Aristócrata inglés venido a menos, por su aspecto y sus actitudes parece que, en el exilio estadounidense, se niega a perder su antiguo lugar histórico-social en el mundo, mostrando, en ciertas tareas domésticas que no dominaba, cierto "reconocimiento de su ascendencia social",71.

La visión del mundo que tiene Artur Sammler es trágica en todo momento, ya que la presencia de la muerte (incluyendo la suya, inminente, la que no llegó en Europa, y la de su sobrino Elya, un anciano al que le lleva seis años) le permite observar los signos de la caída física y moral de los habitantes de Nueva York y del mundo. En el contexto de la excursión a la Luna, la novela de Bellow, de 1970, reflexiona sobre el camino de la humanidad a partir de los grandes problemas políticos, económicos y sociales. Por eso, para producir algunos diálogos sobre estos aspectos trascendentales de la vida humana, aparece un personaje con el que Sammler entablará una discusión filosófica, similar a la que establecen Tardewski y Renzi en Concordia: se trata del profesor indio Govinda Lal, quien extravió su

\footnotetext{
${ }^{68}$ Ricardo Piglia, La ciudad ausente, op. cit., p. 152.

${ }^{69}$ Ibid., p. 142. De acuerdo con la Dra. Ana Rosa Domenella, los ejemplos anteriores también pueden ser analizados desde el concepto que los teóricos de la posmodernidad tienen sobre la palabra "Museo".

${ }^{70}$ Saul Bellow, op. cit., p. 11.

${ }^{71}$ Ibidem.
} 
manuscrito sobre H. G. Wells y la Luna (en realidad, la hija del protagonista, Shula-Slawa, lo ha sustraído) y Sammler lo ha recuperado. Como en la conversación en Concordia, donde dos personas esperan a otra que no va a llegar, el encuentro entre ambos intelectuales ("Sammler sospechaba ahora que Shula se había escapado con El futuro de la Luna para provocar ese encuentro" ${ }^{, 72}$ ) se produce debido a un manuscrito perdido, cuyo tema gira alrededor de las ideas utópicas de un escritor de narraciones de ciencia ficción: Wells. La referencia a El planeta de Mr. Sammler, en Respiración artificial, conduce indirectamente al lector a la órbita del escritor británico, quien establece una crítica a la humanidad en novelas como La máquina del tiempo. En la dualidad entre la novela de Bellow y la de Piglia, se produce una inversión, característica de la poética del escritor argentino: si el futuro de la humanidad, en las ideas de Wells, de acuerdo con Govinda Lal, estará asegurado cuando se colonice la Luna, la gente se salvará del desastre ecológico llegando a otro sitio fuera de la Tierra; en cambio, en 1979, la novela que escribe Enrique Ossorio en el exilio estadounidense, la utopía de la libertad y el fin de las dictaduras se ha convertido en una galería del horror, en una heterotopía. Ossorio ha visto el futuro de la nación argentina y ha escrito las "cartas del porvenir" que no son sino un anticipo de la dictadura de los años setenta y ochenta. Pareciera que, en este sentido, Maggi "desaparece" al descubrir las cartas del porvenir, en el contexto de la dictadura.

La entrevista entre Sammler y Govinda Lal permite la divagación sobre temas como la moral en tiempos de guerra, el sistema capitalista estadounidense, el Holocausto, las ideas de Wells, etc. En cierto sentido, el diálogo que se lleva a cabo entre los intelectuales, junto con los temas que abordan (tomando en cuenta las ideas utópicas de un escritor de ciencia ficción, que sirven para preparar un estudio que en el presente de la novela se encuentra en ${ }^{72}$ Ibid., p. 204. 
calidad de manuscrito), guardan una gran semejanza con Respiración artificial, pero en esta obra la realidad es más cruel que la ficción: la realidad ha imitado al arte y la realidad asumió las formas del terror. El diálogo intertextual de las novela de Piglia con la de Bellow es una referencia empleada para codificar el lenguaje literario y el lenguaje de la resistencia social: la utopía se define, de este modo, como la ruptura en términos estéticos y políticos: "Cuando yo digo utopía pienso en la revolución. La Comuna de París, los primeros años de la Revolución Rusa, eso es la utopía. Y eso es la política. Ser realista es pedir lo imposible. Baudelaire y Marx tenían los mismos enemigos" ${ }^{\text {"73 }}$. Para Piglia, así como para dos de sus escritores predilectos, Bertolt Brecht y Walter Benjamin, la literatura no puede ser concebida sin la presencia de la revolución; por eso, la vanguardia no sólo debe entenderse en términos poéticos, sino también en términos políticos, como Marx y el autor de Las flores del mal. En la búsqueda de un lenguaje poético que se salga de lo "automatizado" (en la línea del formalismo ruso) y que produzca en los lectores un extrañamiento, el futuro de la resistencia social tendría en la creación y el lenguaje artísticos uno de los factores fundamentales. Para Jorge Fornet, Arocena "está lejos de ser el lector ideal. Es una especie de crítico suspicaz que, buscando siempre segundas intenciones, no percibe lo obvio" ${ }^{\text {"74 }}$. Así, aunque Arocena analice con eficacia de inquisidor nazi los textos literarios, su interpretación es errónea e incompleta, ya que el lenguaje del género fantástico, así como sus procedimientos intertextuales y metaficcionales, están fuera de su alcance debido a su formación y al uso de un lenguaje convencional, estatal y realista.

\footnotetext{
${ }_{74}^{73}$ Ricardo Piglia, "Novela y utopía", Crítica y ficción, Anagrama, Barcelona, 2001 (Argumentos, 267), p. 94. ${ }^{74}$ Jorge Fornet, El escritor y la tradición. En torno a la poética de Ricardo Piglia, Letras Cubanas, La Habana, 2005, p. 78.
} 


\subsubsection{9}

Una máxima brechtiana: no conectar con el buen tiempo pasado, sino con el mal tiempo presente WALTER BENJAMIN, "Conversaciones con Brecht"

Para Ricardo Piglia, "La literatura es una forma privada de la utopía"75. Enrique Ossorio, el personaje exiliado en Estados Unidos, lleva a cabo una empresa que es, simultáneamente, política y estética: en sus años de destierro, la distancia espacial y temporal le permite configurar una novela utópica que, en Respiración artificial, aparece de modo fragmentario, como una serie de notas (Work in Progress) que ha incluido en su diario; su labor política también se refleja en las cartas que les envía a sus colegas de la Generación del 37; estas cartas pueden ser también un reflejo de aquellas que en el siglo XX escriben y envían Renzi, Maggi, Angélica Inés Echevarne, Luciano Ossorio (el nieto de Enrique). El tercer capítulo de la primera parte de la novela es el que contiene más metatextos. Aparece después de la primera serie de cartas escritas por Renzi y su tío Marcelo y del encuentro entre aquél y el ex senador Luciano Ossorio (capítulos I y II, respectivamente). El primer fragmento de ese tercer capítulo comienza con una carta de Enrique Ossorio a sus compatriotas, fechada el 4 de julio de 1850, en los días del destierro; el último fragmento corresponde al 30 de julio del mismo año: sólo tiene estas palabras: "Escribo la primera carta del porvenir" (p. 102) -en la que sugiere, implícitamente, que la segunda parte de la novela también es invención suya-. De este modo, los relatos que se encuentran en medio, y que representan un serie de diversos géneros discursivos que van de la carta al diario, pasando por las notas para una novela y la narración sobre Arocena, pueden ser leídos

\footnotetext{
${ }^{75}$ Ricardo Piglia, "Novela y utopía”, Crítica y ficción, op. cit., p. 94.
} 
como parte del texto ficcional de Ossorio, creado en 1850, pero leído en 1979. Las cartas que viajan desde el pasado están destinadas a un lector anónimo, el protagonista de 1979. Marcelo Maggi recibe los documentos del oscuro personaje del siglo XIX de manos de su suegro, Luciano Ossorio. A su vez, Maggi le "hereda" los papeles a su sobrino Emilio Renzi para que él termine la biografía que ha estado realizando en los últimos años y así pueda conocer "la verdad de la historia" ${ }^{\text {" }}$. El procedimiento de lo fantástico en la primera novela de Piglia consiste en que todo lo aparecido en el capítulo III de la novela corresponde al archivo de Enrique Ossorio: la novela del autor Ricardo Piglia, que en los terrenos de la ficción es imaginada y narrada por Emilio Renzi (quien a su vez calla para que otros personajes, como Tardewski, hablen en ella), habla de sí misma: "Renzi no conoce los papeles sino [hasta] un año después, es decir, cuando Tardewski se los entrega al final mismo de la novela, mientras que en ningún momento ha podido tener acceso a la figura y las lecturas de Arocena. ¿Cómo es posible entonces que estén en su relato?”77

Entre las páginas de Ossorio, se encuentra su proyecto novelístico:

\footnotetext{
${ }^{76}$ La cita anterior proviene de la dedicatoria de la novela de Piglia: el escritor argentino recuerda, con estas palabras, a dos compañeros desaparecidos durante la última dictadura militar: Elías y Rubén. La ausencia forzada de los opositores al régimen dictatorial no es explícita: como Maggi, la desaparición física de los activistas no es mencionada, es indecible.

${ }^{77}$ Jorge Fornet, op. cit., p. 84. Una respuesta a la pregunta del crítico cubano se lleva a cabo desde el género fantástico, tomando en cuenta "El impostor" de Silvina Ocampo: la estructura metaficcional de este relato concuerda con la cuentística de lo fantástico en la narrativa de Borges, quien le da una nueva significación al género. Para María Negroni, "El impostor" alude a una cinta de Moebius, a lo que vuelve a empezar una y otra vez. El vértigo producido en el lector al adentrarse en esta estructura narrativa es similar a la de la novela de Piglia (cfr. María Negroni, "Radiografía de la Pampa. Silvina Ocampo: El impostor", Galería fantástica, Siglo XXI, México, 2009, p. 100). Por otro lado, las relaciones entre Piglia y el cuento de Ocampo se documentan en la "Cronología” que el propio autor estableció para la colección Valoración Múltiple: en 1993, el autor de La ciudad ausente "colabora con María Luisa Bemberg en la primera versión del guión de El impostor, basado en un relato de Silvina Ocampo" (Jorge Fornet (comp.), Ricardo Piglia, Casa de las Américas, Bogotá, 2000, p. 279).
} 
$15-7-1850$

La utopía de un soñador moderno debe diferenciarse de las reglas clásicas del género en un punto esencial: negarse a reconstruir un espacio inexistente. Entonces: diferencia clave: no situar la utopía en un lugar imaginario, desconocido (el caso más común: una isla). Darse en cambio cita con el propio país, en una fecha (1979) que está, sí, en una lejanía fantástica. No hay tal lugar: en el tiempo. Aún no hay tal lugar. Esto equivale para mí al punto de vista utópico. Imaginar la Argentina tal cual va a ser dentro de ciento treinta años: ejercicio cotidiano de nostalgia, roman philosophique (p. 80).

A medida que avanza este tercer capítulo de la primera parte, se entremezclan diversos textos: las cartas entre Maggi y Renzi, la que le escribe Maggi a su antiguo suegro Luciano, la carta de Angélica Inés Echevarne, los apuntes biográficos de Enrique Ossorio, etc. A veces, no hay doble espacio en blanco entre una carta y otra, lo que habría sugerido cierto distanciamiento temporal y espacial entre un texto y otro ${ }^{78}$. El lector tiene ante sus ojos los papeles de Ossorio, que se encuentran en estado caótico y que combinan varias voces, lo que produce una especie de vértigo; sin embargo, el narrador omnisciente que sigue de cerca a Arocena explica el origen de las cartas. Dentro, se encuentran los textos de Enrique Ossorio, quien imagina cómo sería su Patria después de ciento treinta años: descubre el mundo del horror y la represión: "Preveo: disensiones, divergencias, nuevas luchas. Interminablemente. Asesinatos, masacres, guerras fratricidas" (p. 70). Este personaje ficcional de la Generación del 37, visionario como Franz Kafka, es el autor de la novela 1979; dentro de esta, se encuentra Respiración artificial; a su vez, dentro de esta, se encuentran los escritos de Enrique Ossorio, entre los que destaca 1979... Esta estrategia metaficcional y fantástica, que por supuesto no niega su estirpe borgiana, cumple una

\footnotetext{
${ }^{78}$ Un ejemplo de lo anterior es la p. 70: después de una nota marginal (en el doble sentido de la palabra) sobre la relación de Ossorio con una prostituta ("Mi amiga, la joven ramera, se llama Lisette Gazel") aparece otro párrafo (sólo separado por punto y aparte y sangría) donde se lee una carta de Maggi a don Luciano, que comienza con el vocativo "Mi querido don Luciano".
} 
función social: "Para Piglia, ser un escritor de su tiempo significa escribir una ficción que no se aleje de lo político [...] Una ficción que aspire a lo imposible, a la utopía, y que articule, a su vez, la contrarrealidad"79. En las notas de Ossorio, se pone en evidencia la poética del autor de Plata quemada cuando el personaje reflexiona sobre las condiciones que su novela debe reunir; al hacerlo, revela el carácter autorreferencial de la novela:

Otra diferencia entre la novela que quiero escribir y las utopías que conozco (T. Moro, Campanela, Bacon): en mi caso no se trata de narrar (o describir) esa otra época, ese otro lugar, sino de construir un relato donde sólo se presenten los posibles testimonios del futuro en su forma más trivial y cotidiana, tal como se le presentan al historiador los documentos del pasado. El protagonista tendrá frente a sí papeles escritos de aquella época futura (p. 83).

Los géneros discursivos de la novela (la carta, el diario, la autobiografía, las notas para una novela, etc.) son los documentos del presente que escribe Ossorio. Su lectura puede interpretarse desde el sentido de la resistencia social en el presente y el futuro, aunque se le imagine desde el pasado. Al respecto, Piglia comenta: "está la idea de alguien que está escribiendo cartas para el porvenir, que en realidad ese futuro es el presente; el presente de la novela es en realidad las cartas que este hombre está enviando desde el siglo XIX ${ }^{80}$ ". Así como en "La otra muerte" de Borges, donde el protagonista tiene un segundo deceso que elimina el anterior, el que lo deshonra por cobarde, en el texto de Ossorio se sugiere la posibilidad de alterar el presente y el futuro desde el pasado: si 1979 es una novela utópica, que roza en cierta medida con el género de la ciencia ficción (cuya presencia será mucho más notoria en la segunda novela de Piglia: La ciudad ausente) y puede interpretarse como una obra que cuestiona el presente (la dictadura argentina en los setenta y ochenta), escrita

\footnotetext{
${ }^{79}$ Laura Demaría, op. cit., p. 33.

${ }^{80}$ Infra, p. 186.
} 
por un exiliado político del siglo XIX, entonces, su lado inverso u opuesto, la novela histórica, no solo funcionaría, en términos pragmáticos, para comprender el pasado, sino también para entender e interpretar el presente y el futuro. Quizá por esa razón, después de darle título a su novela, Ossorio anota lo que será el epígrafe de su texto, que toma de Jules Michelet: "Cada época sueña la anterior" (p. 80). En 1979, título y epígrafe son referentes de una temática del tiempo entendido desde un punto de vista filosófico (roman philosophique). La cita de Michelet que funciona como epígrafe en la novela de Ossorio es una más de las que Piglia invierte en su construcción sintáctica y, en consecuencia, en sus aspectos semánticos y hermenéuticos. En realidad, el epígrafe elegido por Ossorio es casi el mismo que Walter Benjamin decide utilizar como tal para uno de los apartados de su ensayo "París, capital del siglo XIX". En el texto original del escritor alemán (y en su traducción) la cita está escrita en francés: "Chaque époque rêve la suivante". En el siguiente renglón, dentro del epígrafe, se lee: "мichelet: Avenir! Avenir!"81 La sustitución de la palabra siguiente por el vocablo anterior, en la cita de Michelet dentro del texto de Ossorio, funciona para darle otra significación al tema filosófico del tiempo (Avenir es porvenir en español: Piglia desvía el significado de la palabra). Para Walter Benjamin, en todas las sociedades existe una nostalgia por el tiempo pasado; así, se busca volver a reconstruir aquel tiempo, visto como edénico, como utópico, por las clases sociales altas. De ahí el epígrafe que abre su ensayo: "Las aguas son azules y las plantas son rosa; / ¡qué dulce de mirar está la tarde! Salimos de / paseo; las grandes señoras salen de paseo; tras / ellas se orean las señoras pequeñas" ${ }^{\$ 2}$. Esta cita, tomada de Paris capitale de la France, del poeta francés-vietnamita Nguyen-Trong-Hiep, contemporáneo del autor de los Pasajes,

\footnotetext{
${ }^{81}$ Walter Benjamin, "París, capital del siglo XIX", Baudelaire. Un poeta en el esplendor del capitalismo. Iluminaciones II, pról. y trad. de Jesús Aguirre, Taurus, Madrid, 1972, p. 175.

${ }^{82}$ Ibid., p. 171.
} 
refleja la crítica al capitalismo y la burguesía analizados por el autor. En las palabras del epígrafe inaugural, lo nuevo se une con lo viejo: las imágenes que elige una "consciencia colectiva" en lo nuevo y lo viejo "son optativas, y en ellas la colectividad busca tanto suprimir como transfigurar las deficiencias del orden social del producción y la imperfección del producto social" ${ }^{\$ 3}$. En la interpenetración de lo viejo con lo nuevo aparece la imagen de una sociedad sin clases. De este modo, Benjamin comienza hablando de los ideales revolucionarios y utópicos de Fourier para relacionarlos con la arquitectura de los pasajes en París, poco después de la Revolución de 1832:

En el sueño en que a cada época se le aparece en imágenes la que le sigue, se presenta la última desposada con elementos de la protohistoria, es decir una sociedad sin clases. Sus experiencias, depositadas en el inconsciente colectivo, engendran en su interpenetración con lo nuevo utopías que dejan su huella en mil configuraciones de la vida, desde edificios duraderos hasta modas fugaces ${ }^{84}$.

Según Maggi, en carta dirigida a Renzi, Enrique Ossorio pudo haberse ido a estudiar a Francia: "Mientras cursa la universidad se interesa en la filosofía y sigue cursos privados sobre Vico y Hegel con Pedro de Angelis. Sus condiciones eran tan brillantes que De Angelis lo persuade para que continúe sus estudios en París y lo recomienda personalmente en carta a su amigo Jules Michelet” (p. 28). Sin embargo, se queda en Argentina y, en 1837, el mismo año en que se funda el Salón Literario ${ }^{85}$, se convierte en uno de los secretarios de Juan Manuel de Rosas. A partir de esta decisión, nadie sabrá con certeza si es un traidor a la causa revolucionaria o un traidor a la dictadura de Rosas.

\footnotetext{
${ }^{83}$ Ibid., p. 175.

${ }^{84}$ Ibidem.

${ }^{85}$ Cfr. Laura Demaría, op. cit., especialmente pp. 32-44.
} 
Ya en el exilio estadounidense, Ossorio imagina su novela; el epígrafe cambia en una palabra: en lugar de siguiente, escribe la palabra anterior. En el orden cronológico de los hechos, la cita desviada de Michelet puede leerse desde el siglo XX hacia el siglo XIX. Los lectores de 1979, en el siglo XX, o de Respiración artificial, en el mismo siglo y en el XXI, pueden entonces remitirse a la época anterior con la que sueñan, el siglo XIX, para comprender su propio presente y tratar de predecir (y evitar) el futuro que sea semejante al de la dictadura. En la línea de las "Tesis de filosofía de la historia", donde Benjamin analiza el estado de la historia y el desastre futuro a partir de la pintura Angelus Novus de Paul $\mathrm{Klee}^{86}$, la referencia oculta a las ideas revolucionarias y antiburguesas de Benjamin, así como la inversión del sentido en el epígrafe de Ossorio, que cita a Michelet (pero, en realidad, su deuda no es con el escritor francés que iba a ser su maestro en París, sino con el autor judío-alemán), sugieren que la creación literaria y el ejercicio de la imaginación pueden anticiparse al desastre o modificar la realidad: "Cada época no sólo sueña la siguiente, sino que soñadoramente apremia su despertar" ${ }^{27}$.

En Umbrales, Gérard Genette se pregunta, cuando analiza los epígrafes en las obras literarias, sobre la autoría de quien coloca un epígrafe en un libro, si es el autor o el "héroenarrador ${ }^{98}$. En el caso del personaje Enrique Ossorio, a la hora de imaginar su novela, podría decirse que él es el autor, si bien imaginario, de una novela cuya historia transcurre parcialmente en otra novela que la contiene. Interpretada desde el género fantástico, la estrategia literaria de colocar un epígrafe de una cita oculta de Benjamin, hecha por un intelectual decimonónico, supone la presencia de lo sobrenatural: como visionario, Ossorio

\footnotetext{
${ }^{86}$ Walter Benjamin, "Tesis de filosofía de la historia", Para una crítica de la violencia, selec. y trad. de Marco Aurelio Sandoval, Premià, México, 1977 (La nave de los locos).

${ }^{87}$ Walter Benjamin, "París, capital del siglo XIX", op. cit., p. 190.

${ }^{88}$ Gérard Genette, “Los epígrafes”, Umbrales, trad. de Susana Lage, Siglo XXI, México, 2001, p. 128.
} 
no sólo se anticipa al futuro argentino narrado en 1979, sino que además se anticipa a los textos que condensarán las ideas estéticas de la vanguardia con las ideas políticas revolucionarias de filiación marxista. Benjamin es leído en el siglo XIX por Enrique Ossorio porque, en parte, es su doble y lo prefigura.

Un recurso poético que rompe con las categorías propuestas por Genette para el estudio de las funciones en los epígrafes es la inversión, cultivada por Ricardo Piglia en Respiración artificial y otros textos narrativos, como "La loca y el relato del crimen" la clasificación del teórico francés se pueden obtener cuatro funciones, dos explícitas y dos oblicuas. Es probable que el epígrafe de Michelet pueda caber en la tercera función, tomando en cuenta que se trata de una cita transcrita por Ossorio como autor imaginario y por Piglia como autor real. Además de la inversión como recurso poético en la narrativa pigliana, que cambia el sentido de la cita anterior que lleva a cabo Benjamin, por lo que se produce un proceso de apropiación de "París, capital del siglo XIX" y del "epigrafiado"90 Michelet, puede afirmarse que "en un epígrafe lo esencial a menudo no es lo que se dice, sino la identidad del autor y el efecto de garantía indirecta que su presencia determina en el límite de un texto"91. La función del epígrafe sería, por lo tanto, la de manifestar cierta cercanía estética e ideológica entre el epigrafista Piglia-Ossorio y el epigrafiado Michelet, pasando por la cita oculta, más importante que el propio autor de Avenir! Avenir!, hasta

\footnotetext{
${ }^{89}$ Para el análisis de la inversión como un recurso específico en la poética de Piglia, cfr. el segundo capítulo de De la crítica a la ficción, op. cit., pp. 33-73.

${ }^{90}$ Para nombrar las entidades que participan del acto intertextual (hipertextual) que es la selección y citación de un epígrafe, Genette propone los conceptos de "epigrafista" para el autor o "héroe-narrador" (que en Respiración artificial serían dos: el autor Piglia y el personaje Ossorio, que también es autor imaginario), "epigrafiado" para el "autor real o putativo del texto citado" y "epigrafario" para el lector del texto (op. cit., p. 128). Sin embargo, debido a la condición metaficcional de algunas de las grandes obras de la literatura universal, como el Quijote y su metatexto El curioso impertinente, el autor de Palimpsestos también propone otra entidad: el lector imaginario o intradiegético que se une, al final, con el lector real (p. 132). El propio Piglia dedica un ensayo a los lectores imaginarios en El último lector, op. cit., pp. 77-102 y 139-164.

${ }^{91}$ Gérard Genette, op. cit., p. 135.
} 
llegar a Walter Benjamin. En una carta a su traductor Sergio Waisman, Piglia hace notar que las citas deben ser traducidas directamente porque las considera como personajes: "Cuando el personaje es conocido [...] su nombre funciona de manera distinta a cuando es desconocido y produce cierto efecto enigmático" ${ }^{, 92}$. Si la cita es un personaje, de acuerdo con lo que afirma Piglia, la pista que deja en su novela debe ser rastreada hasta "París, capital del siglo XIX" de Benjamin, de acuerdo con la propuesta estético-social de ambos. Lo anterior recoge la idea de "efecto-epígrafe" analizada por Genette en el estudio de la cuarta función de este tipo de exergo: la tradición literaria de Piglia y sus "precursores", en el sentido borgiano-pigliano, hace que el epígrafe ubique al autor de Plata quemada en la línea estética y moral de Walter Benjamin:

Los jóvenes escritores de los años sesenta y setenta [como el Piglia de La invasión y Nombre falso, incluso el de 1980, cuando se publica Respiración artificial] se otorgaban por el mismo medio la consagración de una filiación prestigiosa. El epígrafe es un signo (que se quiere índice) de cultura, de intelectualidad. Esperando las hipotéticas reseñas en las gacetas, premios literarios y otros reconocimientos oficiales, el epígrafe es casi la consagración de un escritor, que por él elige sus pares y su lugar en el Panteón ${ }^{93}$.

Por eso, a pesar del pesimismo implícito que ronda en toda crítica social que se presenta en la obra literaria, el universo de la literatura puede cambiar la realidad en el momento en el que esta comience a imitarlo. No hay que olvidar que la formación intelectual de Piglia también abarca sus estudios en Historia, que la dedicatoria de Respiración artificial va dirigida "A Elías y a Rubén, que me ayudaron a conocer la verdad de la historia” y que la primera novela del escritor argentino se encuentra en la línea filosófica y política de

\footnotetext{
92 Ricardo Piglia citado por Sergio Waisman, "Máquinas creadoras, sitios de resistencia: Ricardo Piglia y la traducción”, en Adriana Rodríguez Pérsico (comp.), Ricardo Piglia: una poética sin límites, Universidad de Pittsburgh, Pittsburgh, 2004, p. 59.

${ }^{93}$ Gérard Genette, op. cit., p. 136.
} 
Benjamin y Brecht; así, puede afirmarse que la historia es un lugar fundamental de la poética pigliana: "la historia es el lugar en el que se ve que las cosas pueden cambiar y transformarse" ${ }^{\text {"94 }}$.

${ }^{94}$ Ricardo Piglia, “Novela y utopía”, op. cit., p. 91. 


\section{LA CIUDAD AUSENTE: NOVELA INFINITA}

\subsection{La ciudad ausente en la encrucijada de los géneros: ¿Literatura fantástica o ciencia-ficción?}

En todas las ficciones, cada vez que un hombre se enfrenta

con diversas alternativas, opta por una y elimina las otras; en la del casi inextricable Ts'ui Pên, opta-simultáneamente-

por todas. Crea, así, diversos porvenires, diversos tiempos, que también proliferan y se bifurcan.

Creia en infinitas series de tiempos, en una red creciente $y$ vertiginosa de tiempos divergentes, convergentes y paralelos. JORGE LUIS BORGES, "El jardín de senderos que se bifurcan"

Una primera lectura de La ciudad ausente ${ }^{95}$ puede ubicar esta novela experimental, casi de manera inmediata, dentro del género de la ciencia-ficción; sin embargo, mi interpretación busca comprender esta obra, una de las cúspides narrativas y poéticas de su autor, como parte de un proyecto literario que contempla el género fantástico dentro de la tradición argentina. La ciudad ausente es una novela que difícilmente se deja encasillar en una categoría o un género; la estructura metadiegética y la polifonía narrativa tampoco permiten una lectura reduccionista, ya que se plantean problemas estéticos cuya resolución queda inconclusa o que continúan indagándose en obras ulteriores.

Este problema de la clasificación -que, por lo demás, corresponde a un intento simplificador propio de la historia de la literatura- en la obra de Ricardo Piglia es una constante que puede analizarse a la luz de su poética. Al respecto, Jorge Fornet afirma: “en Piglia las fronteras entre los géneros son difíciles de precisar. No es extraño que en sus

\footnotetext{
${ }^{95}$ Ricardo Piglia, La ciudad ausente, op. cit. Para este capítulo, después de cada cita, solo pondré el número de página correspondiente.
} 
ficciones aparezcan formas del discurso ensayístico, como tampoco que sus ensayos y entrevistas se vean poblados por personajes y hechos ficticios que aparentan ser reales, apoyados en la lógica del género"96.

Otra opinión sobre los géneros se encuentra en el prólogo a la versión gráfica de $L a$ ciudad ausente, en un nuevo experimento que acerca los productos de la alta cultura, como esta segunda novela pigliana, de gran complejidad, con los productos de los mass media:

[...] había en esta novela un acercamiento de Piglia a la literatura fantástica y a la ciencia ficción (sin naves espaciales ni alienígenas; una ciencia ficción a la argentina: sabios locos que se encierran en altillos para fabricar máquinas desmesuradas que detengan el tiempo y devuelvan lo perdido). Los géneros (la literatura fantástica, la ciencia ficción, el policial, el periodismo) siempre han estado en el centro de nuestra tradición y nuestros mayores escritores han elegido estos caminos, en lugar del realismo; con La ciudad ausente Piglia aceptó lo que le faltaba de completar de este legado y así buscó la perfección en la combinación inesperada, en las variaciones de la imaginación, en la invención de una Buenos Aires de pesadilla ${ }^{97}$.

De acuerdo con lo anterior, puede afirmarse que los cruces de los géneros son una constante en la literatura de Piglia, y por lo tanto resulta ocioso el intento de ubicar sus obras en una o más categorías. Sin embargo, la discusión sobre los intentos de fijar cada novela en un

\footnotetext{
${ }^{96}$ Jorge Fornet, "Prólogo" a Ricardo Piglia, op. cit., p. 11. Probablemente, de modo más explícito, Formas breves y El último lector son obras donde más se experimenta con el cruce de géneros literarios. El primer libro contiene una serie de ensayos, notas, relatos y narraciones autobiográficas (o pseudoautobiográficas) que cuestionan, implícitamente, la clásica ubicación de los géneros; el segundo libro es más provocativo: se trata de un conjunto de ensayos precedidos por un "Prólogo" que en realidad es un cuento, cuyas versiones anteriores eran más largas y no habían sido publicadas antes en un volumen de relatos de Piglia. El último lector, además, aparece en la colección Narrativas hispánicas de Anagrama. (Para un mayor acercamiento a estos juegos estéticos, cfr. los capítulos IV y V de De la crítica a la ficción, op. cit., pp. 99-155).

${ }^{97}$ Pablo de Santis, "Prólogo. Caligrafía nocturna", Ricardo Piglia, La ciudad ausente, adaptación y pról. de Pablo de Santis, ilustraciones de Luis Scafati, Libros del Zorro Rojo, Barcelona-Madrid, 2008 (La novela gráfica), p. 8.
} 
género $^{98}$ puede funcionar para indagar en su poética, lo que ofrecería una perspectiva diferente de la lectura que ve la novela como una obra representativa de la ciencia-ficción.

En este sentido, mi lectura de La ciudad ausente, en el marco del estudio de la poética de Piglia, se acerca más a las posibilidades narrativas de la literatura fantástica, con lo que se desplazaría una lectura generalizada que tiende a ubicar la novela en los campos de la ciencia-ficción; por otro lado, los acercamientos que la mayoría de los críticos literarios ha llevado a cabo de los textos de Piglia se enfoca, predominantemente, a interpretarlos como un sitio de resistencia social y como un constante asedio a la tradición literaria ${ }^{99}$.

Cabe señalar que estas perspectivas críticas no mantienen una posición antagónica; se trata, ante todo, de analizar la poética de Piglia en función de su posición política, del giro que el canon literario ha dado debido a la influencia de sus opiniones y de sus estrategias narrativas, ensayísticas y estéticas, así como de los gestos de ruptura y tradición con los que cada obra se caracteriza.

\footnotetext{
${ }^{98}$ Las novelas de Piglia escapan a una categorización reduccionista que podría consumirlas (en el sentido del consumismo de las leyes mercadotécnicas de los productos culturales y en el sentido que le da Umberto Eco al agotamiento producido por los medios masivos de comunicación): Respiración artificial está en los límites del género policial y, en menor medida, de la novela histórica, además de ser una "novela-ensayo", como la define Juan José Saer; La ciudad ausente se inserta en los géneros llamados todavía marginales: conviven el policial, la ciencia-ficción y el fantástico (aunque mi perspectiva apunta al predominio del último), caros al proyecto literario de Borges y fundamentales en la revisión que Ricardo Piglia hace de la tradición argentina, en la que por supuesto él mismo se ubica; Plata quemada se encuentra a caballo del género policial y de las crónicas periodísticas cercanas a la escritura de Roberto Arlt; por último, Blanco nocturno, la más reciente novela del autor argentino, no sólo se lee desde las convenciones del género policial, sino también desde lo que quizá sea en un futuro un nuevo género: la "ficción paranoica", ya que la intriga criminal se resuelve pronto y el texto pasa a otro nivel narrativo, donde la discusión se centra en la relación entre ética y estética, siempre desde el punto de vista brechtiano y los problemas morales que genera el sistema capitalista en el contexto de la relación ciudad-campo.

${ }^{99}$ La postura que analiza la poética de Piglia desde la revisión que este lleva a cabo de la tradición literaria argentina es, probablemente, la predominante en los estudios literarios. Cfr., por ejemplo, los estudios de largo aliento de Jorge Fornet, El escritor y la tradición, op. cit; Nicolás Bratosevich, Ricardo Piglia y la cultura de la contravención, Atuel, Buenos Aires, 1997 (Los Argentinos); María Antonieta Pereira, Ricardo Piglia y sus precursores, trad. de Adriana Pagano, pról. de Noé Jitrik, Ediciones Corregidor, Buenos Aires, 2001, además del análisis desde una perspectiva historiográfica y de resistencia social, mencionado en el capítulo anterior.
} 
En el caso de La ciudad ausente, la novela se distingue por postular una ambigüedad en torno a los conceptos de realidad y ficción; Buenos Aires aparece representada como una ciudad de lo irreal o que, por lo menos, refleja un estado de inestabilidad, que permea la vida cotidiana, en un ambiente agresivo y con aires de persecución para sus habitantes: "La información estaba muy controlada. Nadie decía nada. Sólo las luces de la ciudad siempre encendidas mostraban que había una amenaza. Todos parecían vivir en mundos paralelos, sin conexión" (p. 14). Las luces encendidas, en el día, son una señal de la alteración del sistema gubernamental y de los tejidos de la sociedad. En las primeras líneas, el ambiente represivo anuncia o sugiere una conexión con los géneros marginales: la novela negra, la literatura fantástica y la ciencia ficción. Para Edgardo H. Berg, más que la situación inicial, es el tema central, la muerte de la mujer amada, el que detona la presencia de un mundo diferente al de nuestra "realidad": "La pérdida de la mujer amada suscita la reflexión filosófica y dispara la narración hacia la construcción alternativa de un mundo virtual. En este sentido, Piglia con La ciudad ausente desarrolla una peculiar filosofía cognitiva sobre los mundos paralelos y posibles, explorando en su desarrollo argumental la posibilidad óntica de mundo ficcionales" ${ }^{\prime 100}$. Este acercamiento de Berg desde la creación de mundos paralelos, al estilo de "Tlön, Uqbar...", de Borges, no sólo permite una indagación sobre los géneros, también sugiere que el espacio literario es un sitio que postula la posibilidad de un mundo diferente al actual: la literatura es el espacio donde todo es posible, si la pensamos en los límites utópicos de "La isla", hacia el final de la novela.

Esta hibridez en los géneros está pensada, para Berg, en una relación implícita entre la segunda novela de Piglia y los textos de Philip K. Dick, tomando en cuenta, también, las

\footnotetext{
${ }^{100}$ Edgardo H. Berg, "Ricardo Piglia: los papeles de un relato futuro", Poéticas en suspenso. Migraciones narrativas en Ricardo Piglia, Andrés Rivera y Juan José Saer, Biblos, Buenos Aires, 2002, p. 81.
} 
versiones cinematográficas de las novelas de este escritor estadounidense. Probablemente, el crítico argentino es el primero en establecer, de modo explícito, la relación entre ambos autores y sus obras, tomando en cuenta, principalmente ¿Sueñan los androides con ovejas eléctricas? y La ciudad ausente en el cruce de una memoria artificial impuesta en el cuento “Cirugía psíquica de extirpación” de Macedonio Fernández, en "Los nudos blancos” y en la narración, ya clásica, del género de ciencia ficción que Dick contribuyó a renovar ${ }^{101}$. Sin embargo, aparte de estas referencias, la relación entre ambos escritores se pierde de vista en la cohesión del resto de las observaciones del crítico.

Siguiendo la línea intertextual trazada por Berg, podemos partir de las pistas que el propio Ricardo Piglia va dejando, de modo oculto, en sus ensayos, notas y entrevistas. Casi de paso, indirectamente, permite que aparezcan rastros que, si se atienden, pueden contribuir a dar con la clave de algún aspecto de su poética. Por eso, la lectura de $E l$ hombre en el castillo de Philip K. Dick, en mayor medida que ¿Sueñan los androides...?, funciona para ubicar La ciudad ausente dentro del género fantástico.

En El último lector, Piglia analiza brevemente esta novela que, como la suya, cuestiona lo que entendemos por "realidad":

El hombre en el castillo, la novela de Philip Dick, nos instala en un futuro incierto, un mundo paralelo en el que los nazis han ganado la guerra y los japoneses controlan la costa oeste de los Estados Unidos. Amenazados por la incertidumbre, todos leen un libro para tomar decisiones, aun las más insignificantes: el I Ching. Lo leen a la Bovary: sus vidas se estructuran sobre la lectura de ese texto y el desciframiento del oráculo ${ }^{102}$.

\footnotetext{
101 Ibid., p. 82.

${ }^{102}$ Ricardo Piglia, "La linterna de Anna Karenina”, El último lector, Anagrama, Barcelona, 2005 (Narrativas hispánicas, 376), pp. 150-151.
} 
El comentario sobre la novela de Dick es uno más de los guiños que Piglia dirige a sus lectores (en un ensayo que habla sobre los lectores imaginarios que siguen los "rastros de lectura"); en este caso, más allá del tema que lo ocupa, a propósito de los lectores y las pistas que estos van encontrando en lo que leen, podemos unir, en retrospectiva, El hombre en el castillo con La ciudad ausente: en la descripción que Piglia hace de aquella novela, puede percibirse un homenaje que en realidad ya estaba presente, de modo implícito u oculto, en su segunda novela y en otros textos de la época, como la nouvelle "Prisión perpetua", donde aparecen algunos personajes que consultan el I Ching de modo obsesivo, a la manera de Madame Bovary: "Había una mujer que no hacía nada sin consultar el IChing. Se imaginaba una ruleta donde las apuestas se pagan con acontecimientos de la vida del que juega" ${ }^{\prime 103}$. Este pasaje es un fragmento de los relatos que pueblan la nouvelle y que muestran una relación intratextual muy cercana en los niveles cronológico, temático y estructural, con La ciudad ausente ${ }^{104}$. Inclusive, existe un paralelismo con otra microhistoria, proveniente de las narraciones de la máquina Elena, donde otra mujer deja a su marido para ir al casino, ganar y suicidarse (“Una mujer”, pp. 47-48). En el breve relato metadiegético de "Prisión perpetua" que acabo de citar, la mujer abandona a su marido, con los ahorros de ambos, por órdenes del I Ching. Su cercanía es tal con los personajes de El hombre en el castillo, como Abendsen, quien escribió su novela formulando preguntas e

\footnotetext{
${ }^{103}$ Ricardo Piglia, "Prisión perpetua”, Prisión perpetua, Anagrama, Barcelona, 2007 (Narrativas hispánicas, 422), p. 42.

${ }^{104}$ La estructura bipartita consiste en una puesta en abismo donde la primera parte del texto, "En otro país", anuncia un cuento como producto de la influencia decisiva de Steve Ratliff sobre el autor-narrador-personaje Piglia en "El fluir de la vida", el cuento-homenaje a ese escritor estadounidense ficcional que es elevado a la categoría de real mediante la creación verbal. Para un análisis de las relaciones entre los dos textos de la nouvelle, cfr. Jorge Fornet, El escritor y la tradición, op. cit., pp. 105-109, y De la crítica a la ficción..., op. cit., pp. 74-80, para un análisis de "El fluir de la vida".
} 
interpretando las respuestas de ese libro-oráculo, que "a veces consultaba el I-Ching para saber si debía consultar el I-Ching"105.

En su relación con El hombre en el castillo, La ciudad ausente puede ser leída, también, como un mundo paralelo, más que como una obra de ciencia-ficción que narra sucesos futuros de nuestro presente. En la novela de Dick, el mundo paralelo representa el triunfo de alemanes y japoneses sobre los Aliados; Estados Unidos ha perdido la mitad de su territorio (la costa oeste), se encuentra amenazado y en las condiciones propias de un país subalterno y colonizado. A pesar de lo anterior, y aunque las descripciones del narrador postulan la presencia de un gran campo de exterminio en África, el sometimiento del pueblo estadounidense y la extensión de los dominios de Alemania en casi todo el continente europeo, existe una novela prohibida, que circula de modo clandestino y que niega la realidad: La langosta se ha posado, cuyo título, según uno de los personajes, está tomado de un versículo de la Biblia:

Todos los personajes principales de la novela de Dick están leyendo el libro en distintos momentos. Para algunos lectores la novela no tiene sentido, para otros plantea ciertas interrogantes. Sólo uno de los protagonistas del libro de Dick (Juliana, una joven profesora de judo inteligente y decidida) acepta plenamente la versión, está segura de que la novela dice la verdad. Segura de que el protagonista ha hablado de su universo, del que la rodea aquí y ahora. Quiere que vea las cosas tal como son. De hecho, parece ser la única que lo acepta y lo sabe. En cierto sentido ella es la única lectora $^{106}$.

De este modo, se produce un juego autorreferencial a partir de que esa realidad, donde los alemanes ganaron la Segunda Guerra, está cuestionada por otra, prohibida y subterránea: los ingleses y los estadounidenses sí ganaron la guerra, pero los alemanes, de un modo

\footnotetext{
${ }^{105}$ Ricardo Piglia, "Prisión perpetua", op. cit., p. 44.

${ }^{106}$ Ricardo Piglia, "La linterna de Anna Karenina”, op. cit., p. 151.
} 
desconocido, han ocultado la verdad por siglos -la historia se desarrolla, al parecer, en el siglo XXV-. Solo el novelista Hawthorne Abendsen (quizá su nombre sea un homenaje al autor de Wakefield), a través de la consulta paciente y lenta del I Ching, conoce cuál es la realidad, que re-crea en La langosta se ha posado, obra que los lectores ficcionales (los narratarios) leen por completo y los lectores implícitos conocemos mediante la puesta en abismo de algunos fragmentos.

Esta estructura metadiegética, donde una realidad niega otra realidad que a su vez niega "nuestra realidad", es uno de los recursos narrativos que, seguramente, Dick tomó de la tradición literaria argentina, particularmente de Borges; existen ciertos aspectos que podrían indicar la influencia del autor de Ficciones. "El jardín de senderos que se bifurcan” y "Tlön, Uqbar, Orbis Tertius" serían los textos más representativos: en el primero, el encuentro azaroso (¿realmente azaroso?) de Yu Tsun con el inglés Stephen Albert sugiere la existencia laberíntica de tiempos y mundos paralelos ${ }^{107}$; en "Tlön”, el mundo descrito en la Enciclopedia Británica poco a poco empieza a apoderarse de la realidad del narradorpersonaje Borges. En esta línea argumental, propia de la literatura fantástica, los relatos de la máquina Elena funcionan de modo semejante a La langosta se ha posado de Dick y a los metatextos de los cuentos de Borges: la realidad oficial, controlada por los aparatos gubernamentales, es negada por una máquina que relata de modo mucho más complejo de

\footnotetext{
${ }^{107}$ En un juego literario donde la inversión es uno de los recursos poéticos más frecuentes en la obra narrativa de Ricardo Piglia, las figuras de Yu Tsun y el inglés Stephen Albert pueden reflejarse en el guardián Fuyita, de origen japonés o coreano, y Junior, hijo de ingleses, personajes de La ciudad ausente. En esta novela, Fuyita ("Yo soy un espía, un extranjero [...] trabajo para el ingeniero Richter", p. 61) sirve de guía a Mac Kensey para entender los relatos de la máquina; el Museo, además, puede ser visto como un laberinto y una novela que contiene todos los relatos y todas las variantes (como el libro El jardín de senderos que se bifurcan del antepasado de Yu Tsun). Cfr. Jorge Luis Borges, "El jardín de senderos que se bifurcan", Ficciones, Alianza Editorial, Madrid, 2000. Por su parte, José Manuel González descubre que en La invención de Morel se menciona a un tal Fuyita, pintor de profesión (cfr. José Manuel González Álvarez, op. cit., n. de la p. 157). Tomando en cuenta esta asociación, podría mencionarse que, aunque Piglia no es muy entusiasta a la hora de hablar de Bioy Casares, la referencia intertextual funciona como una marca de la presencia de lo fantástico en su obra, al insertarse en la tradición de Borges y Bioy.
} 
lo que el Estado puede comprender y aceptar. Además, el modo de narrar de la máquina es metaficcional y multiforme, ya que las historias que cuenta son, a su vez, alegorías del relato central, es decir, son alegorías del relato del origen de la máquina y su intento de desmantelamiento por parte del gobierno y la policía.

El juego literario de Dick se encuentra en la estructura metaficcional de su novela: el mundo paralelo que describe es negado por otro mundo paralelo, narrado y descrito en una novela, una obra de ficción. Al final, cuando Juliana logra entrevistarse con Abendsen y este confirma su interpretación sobre la supuesta realidad que describe la novela y cuya construcción fue hecha con base en la preguntas formuladas al I Ching, los lectores tenemos la certidumbre de la existencia de ese otro mundo, donde ganaron los ingleses y los estadounidenses sobre los alemanes y los japoneses pero, de ese conocimiento, surge la amargura de la realidad, pues se vive en una ilusión. El propio autor Abendsen, que se negaba a aceptar del todo lo que narra en La langosta se ha posado, acepta a regañadientes la certeza de Juliana, quien para comprobar su teoría ha recurrido nuevamente al I Ching, lo que deja a los personajes en un estado de indefensión:

- ¿Sabe qué es usted? -Se volvió a Caroline, que estaba al lado.- Esta muchacha es un daemon de los mundos subterráneos que [...] recorre incansablemente la faz de la tierra [...] Hace lo que le es instintivo, expresándose así. No tenía la intención de venir aquí y hacer daño; simplemente le ocurrió, así como nos ocurre a nosotros que llueva o haga sol. Me alegra que haya venido. No lamento haber descubierto esto, la revelación que ella encontró en el libro. No sabía lo que iba a hacer aquí o lo que iba a descubrir. De modo que no nos enojemos, ¿eh?

-Es terriblemente destructiva -dijo Caroline.

-Así es la realidad -dijo Hawthorne y tendió una mano a Juliana ${ }^{108}$.

${ }^{108}$ Philip K. Dick, El hombre en el castillo, trad. de Manuel Figueroa, Minotauro, Buenos Aires, 2007, p. 261. 
En su afán por abstraerse de la opresiva realidad, los personajes de El hombre en el castillo leen con placer La langosta se ha posado pero, cuando se descubre que esta novela no es ficcional, sino que está basada en la realidad, los personajes adquieren un estado de ánimo sombrío, pues no se vislumbra el modo de producir un cambio. Este cruce entre realidad y ficción permite que La ciudad ausente sea leída como una novela fantástica que confunde la noción de lo real. Publicada por primera vez en el contexto de la política del olvido que la presidencia de Raúl Alfonsín (1983-1989) había emprendido y Carlos Saúl Menem había acentuado con la finalidad de terminar los juicios contra los militares que tan violentamente actuaron sobre los ciudadanos durante la última dictadura argentina $(1976-1983)^{109}$ y en la época que fue conocida, años más tarde, como posdictatorial, en el marco del neoliberalismo, la globalización económica y la posmodernidad ${ }^{110}$, esta novela refleja los intentos, por parte del Estado, de fijar una realidad donde no existan actividades subversivas que cuestionen sus decisiones y acciones. Por eso, de manera semejante a $E l$ hombre en el castillo, la policía persigue a los disidentes e intenta establecer una realidad homogénea y oficial, pero no puede detener del todo los relatos de la máquina, que circulan de modo clandestino y narran los horrores de las acciones estatales, tomando en cuenta los crímenes de la dictadura, sus secuelas inquisidoras en la presidencia de Menem y el ambiente de impunidad que se respiraba todavía antes de la llegada de Néstor Kirchner a la presidencia.

En La ciudad ausente, la percepción de una realidad deformada y alterada se describe y narra a través de numerosos relatos que escapan de una visión dual, lo propio y lo otro (que

\footnotetext{
${ }^{109}$ Cfr. Luis Alberto Romero, Breve historia contemporánea de la Argentina (1916-1999), FCE, Buenos Aires, 2004, pp. 248-253.

${ }^{110}$ Cfr. Francine Masiello, "Introducción" a El arte de la transición, trad. de Mónica Sifrim, Norma, Buenos Aires, 2001, pp. 25-26.
} 
fomenta la alienación entre los seres humanos), para proponer una visión heterogénea y múltiple, que resista contra toda tentación tendente a un proyecto nacional donde los ciudadanos sean homogéneos y se estén domesticados. Los relatos de la novela ofrecen la idea de lo fragmentario como una respuesta frontal a la idea totalizadora de los regímenes fascistoides, que buscan encasillar, clasificar y relegar al olvido las obras "incómodas" para un sistema político ${ }^{111}$. La estructura metadiegética, fragmentaria y multiforme de La ciudad ausente -que rompe con la dualidad de la novela de Dick, por lo que se trata de una obra con un mayor grado de complejidad-, así como la puesta en duda de los conceptos de "realidad" y "ficción", como se ve en los múltiples relatos autorreferenciales, permite no una lectura oficial y monolítica, sino una lectura de resistencia, de desautomatización literaria, que renueve los modos de escribir y, sobre todo, de leer. Dice Piglia a propósito de la novela de Dick (pero la siguiente cita también puede funcionar de referencia para comprender La ciudad ausente): "El contraste entre ficción y realidad se ha invertido. La realidad misma es incierta y la novela dice la verdad (no toda la verdad). La verdad está en la ficción, o más bien, en la lectura de la ficción”"112.

Este modo de leer puede ajustarse a ambas novelas, que comparten una estructura autorreferencial. En un diálogo, varios personajes de la novela de Dick comentan la novela de Abendsen, intentando ubicarla en un género específico:

-No es una novela policial -dijo Paul-. Al contrario, una forma interesante de la ficción, posiblemente relacionada con la ciencia-ficción.

\footnotetext{
${ }^{111}$ Al respecto, Francine Masiello afirma: "La fragmentación de cualquier visión totalizadora aparece como una forma convincente de rebelión contra el poder del Estado y sus modelos rígidos de representación" (Ibid., p. 31).

${ }_{112}$ Ricardo Piglia, "La linterna de Anna Karenina", op. cit., p. 151.
} 
-Oh no -se opuso Betty-. No hay ciencia en la obra. No se trata del futuro. El tema de la ciencia ficción es el futuro, en particular un futuro donde la ciencia ha avanzado todavía más. El libro no tiene esas características.

-Pero -dijo Paul- habla de otro presente posible. Hay muchas novelas de ciencia ficción de esa especie $^{113}$.

El problema de la ubicación genérica de El hombre en el castillo queda irresuelto, ya que Paul concluye la breve discusión citada afirmando que ha leído muchas obras de cienciaficción desde la adolescencia. A pesar de lo anterior, el autor Dick, a través de este diálogo, no afirma que esta obra forme parte de su proyecto de ciencia-ficción, donde destaca ¿Sueñan los androides con ovejas eléctricas? y su versión cinematográfica, Blade Runner.

El hombre en el castillo, más que una novela de ciencia-ficción, es una obra fantástica que describe y narra acciones en un mundo paralelo ${ }^{114}$. Esta práctica, cultivada magistralmente por dos grandes exponentes del género en Latinoamérica, como Borges y Bioy Casares ${ }^{115}$, quizá reciba otro nombre. Para Umberto Eco, este tipo de narrativa se llama ucronía, y se separa de otros géneros pertenecientes a la literatura fantástica, cuya principal característica es su alejamiento del "mundo real": alotopía, utopía y metatopía y metacronía. La alotopía pertenece al mundo de lo maravilloso, y sus leyes no son cuestionadas en absoluto; la utopía corresponde a mundos inaccesibles, con ejemplos como

\footnotetext{
${ }^{113}$ Philip K. Dick, op, cit., p. 115.

${ }^{114}$ La presencia del mundo paralelo es tan percibida por algunos personajes que, inclusive uno de estos, el respetable señor Tagomi, de origen japonés, sorpresivamente logra penetrar, por unos minutos, ese mundo paralelo: "Era inútil, sólo se veían coches privados y autobuses. Coches que parecían trituradoras brutales y enormes, de formas desconocidas [...] Tenía que tranquilizarse, tomar un respiro. Enfrente, un mísero restaurante. Sólo blancos adentro, todos almorzando. El señor Tagomi empujó las puertas de vaivén. El local olía a café, y en un rincón un grotesco aparato automático aullaba una música. El señor Tagomi parpadeó y fue hacia la barra. Todos los taburetes ocupados por blancos. El señor Tagomi habló y algunos de los blancos alzaron los ojos. Pero nadie se movió. Nadie le dejó el sitio. Todos se volvieron de nuevo hacia sus platos [...] ¿Dónde estaba? Fuera del mundo cotidiano, el espacio y el tiempo de costumbre" (ibid., pp. 235-236).

${ }^{115}$ Cfr. Adolfo Bioy Casares, "La trama celeste" Historias fantásticas, Alianza Editorial, 2000, Jorge Luis Borges, "Fragmentos de una tablilla", Obra poética, 3, Alianza Editorial, Madrid, 1999, pp. 280-281 y Alfonso Macedo Rodríguez, De la crítica a la ficción..., op. cit., p. 116. En los textos de los dos escritores argentinos, Cartago sobrevivió a la guerra contra Roma; así, siguiendo al poeta de la tablilla que Borges "recupera" para los lectores, la lengua púnica "será la lengua del orbe" (p. 280), y no el latín.
} 
la utopía de Tomás Moro o la sátira de Swift ${ }^{116}$. Aquí, probablemente, cabe el relato "La isla", que cierra el tercer capítulo de La ciudad ausente. En el tercer caso, "la utopía puede transformarse en ucronía, en que el contrafactual adopta la forma siguiente: ¿qué habría ocurrido, si lo que ha sucedido realmente hubiera sucedido de otro modo: por ejemplo, si no hubieran asesinado a Julio César en los idus de marzo?"117 En esta serie se ubica la novela de Dick y, en consecuencia, La ciudad ausente, ya que el último subgénero descrito por Eco, metatopía y metacronía, es el que corresponde a la ciencia-ficción, por lo que la ucronía queda descartada de esta tendencia:

El mundo posible representa una fase futura del mundo real presente: y por distinto que sea estructuralmente del mundo real, el mundo posible es posible (y verosímil) precisamente porque las transformaciones que sufre no hacen sino completar tendencias del mundo real. Definiremos este tipo de literatura fantástica como novela de anticipación y utilizaremos esta noción para definir de modo correcto la ciencia-ficción ${ }^{118}$.

Tomando en cuenta la práctica especular de Dick y el análisis de Umberto Eco, puede afirmarse que El hombre en el castillo y La ciudad ausente son obras narrativas más cercanas a la literatura fantástica que a la ciencia-ficción; inclusive, Eco parte de un concepto general, el de literatura fantástica, para abordar cuatro subgéneros, donde diferencia de modo claro la ucronía de la metacronía y metatopía ${ }^{119}$.

\footnotetext{
${ }^{116}$ Umberto Eco, "Los mundos de la ciencia-ficción", De los espejos y otros ensayos, trad. de Cárdenas Moyano, Lumen, Barcelona, 1988, pp. 186-187.

${ }^{117}$ Ibid., p. 187.

${ }_{118}^{11}$ Ibidem.

${ }^{119}$ Por su parte, al analizar La ciudad ausente, José Ramón Ruisánchez emplea el término de heterotopía (que recogió de un texto de Michel Foucault) como sinónimo de lo que Eco llama ucronía. La heterotopía significa "todo lugar es también otro lugar". Quizá sea más conveniente emplear el término de Eco porque contempla la noción de tiempo, tan importante por su cercanía con el concepto de historia y con la formación de historiador de Piglia. (Cfr. José Ramón Ruisánchez, "Heterotopías: imaginación politica y espacio en Piglia y Aira", Signos literarios (México), v. II, núm. 3, enero-junio de 2006, p. 44.)
} 
En ambas novelas se cuestiona la realidad, que está controlada por el Estado (argentino o alemán). La última línea de la siguiente cita, tomada de un diálogo entre Junior y Renzi, refleja el velado homenaje de Piglia a Dick:

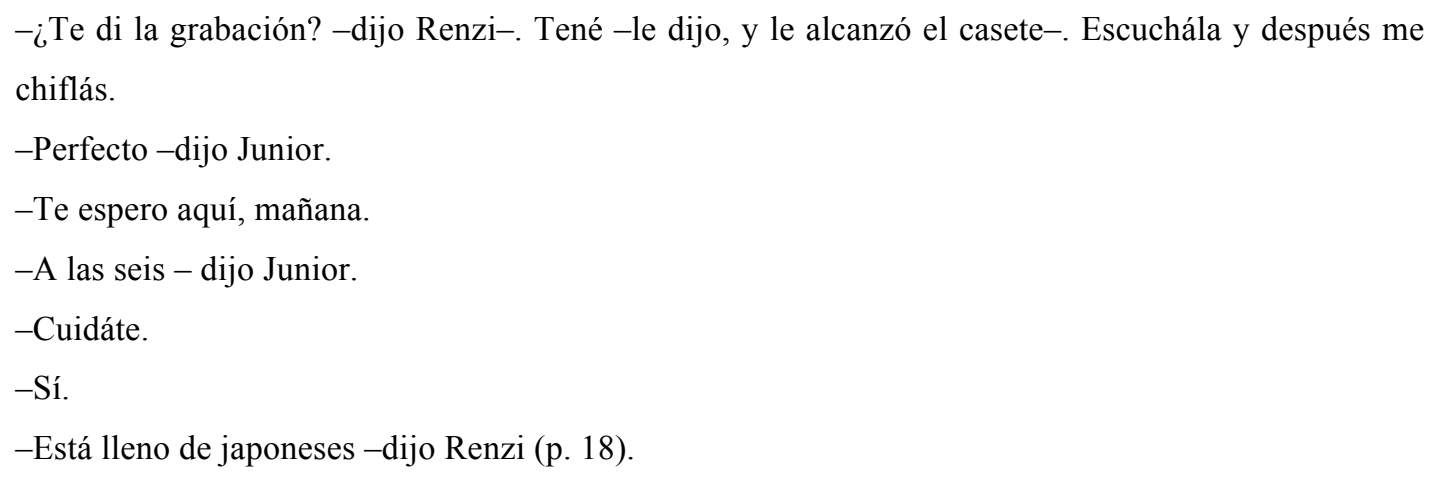

¿Qué significa la última frase de Renzi? ¿Acaso el personaje se refiere al barrio donde se encuentra el hotel Majestic, domicilio de Fuyita, el japonés que custodia el Museo? Más bien, se trata de una alusión intertextual a la novela de Philip K. Dick, cuyo tema central es, como hemos visto, la negación de una realidad mediante otra realidad: una doble ucronía, paradójicamente.

En esta línea, un breve diálogo entre Junior y la policía, que se produce cuando esta llega para arrestar a Julia (cuyo nombre bien puede asociarse al de Juliana, el personaje femenino central de El hombre en el castillo) en la habitación de hotel donde se encuentran, tiene que ver con ese obsesivo control de la sociedad:

-Usted es inglés -dijo el policía.

-Hijo de ingleses -dijo Junior.

-Trabajó en la serie sobre el Museo, en El Mundo.

-Trabajo todavía y tengo mis fuentes a disposición. Si quiere llamar al diario.

-Una pregunta de rutina -dijo el comisario-. ¿Quién ganó la guerra?

-Nosotros. 
El comisario sonrió. Querían controlar el principio de la realidad.

-Gracioso. ¿Nosotros quiénes?

-Los kelpers -dijo Junior (pp. 93-94).

La pregunta de rutina es una alusión a la Guerra de las Malvinas en la época final de la Dictadura. El control de la información fue tal que a los argentinos se les ocultó el desastre en el momento en que la derrota era inevitable. Inclusive, las fuentes oficiales manejaron la versión de que Inglaterra estaba perdiendo ${ }^{120}$. El fervor de patriotismo y nacionalismo fue, como sabemos, una de las tácticas de la dictadura militar para mantener enajenada y controlada a la población. En la época en la que transcurren las acciones de La ciudad ausente, es decir, la década de los noventa (hay una referencia, por ejemplo, a la estrella de basketball Michael Jordan, figura deportiva de la década, y a la presencia de Emilio Renzi, que lleva años trabajando en $E l M u n d o^{121}$ y que guía a Junior en su entrada a la labor periodística), todavía hay un residuo nacionalista en torno a la posesión de las islas, si bien se ha aceptado la derrota militar, aunque de un modo poco claro, por lo que la pregunta rutinaria es semejante al intento de negar la realidad en la novela de Dick (y en la metanovela). Las respuestas evasivas e ingeniosas de Junior reflejan, además, su posición de marginado, ya que el término kelper $^{122}$, que le sirve para identificarse ante la autoridad,

${ }^{120}$ Cfr. Luis Alberto Romero, op. cit., pp. 234-235.

${ }^{121}$ Otra referencia a la ucronía que describe Eco: el diario El Mundo dejó de existir mucho antes de que Piglia comenzara a publicar sus primeros textos, pero su presencia, en el universo de La ciudad ausente, "La loca y el relato del crimen", Plata quemada y Blanco nocturno, es parte de la "realidad"; la importancia y la presencia de $E l$ mundo en la ficción pigliana se debe a que en ese periódico Roberto Arlt escribió muchas de sus grandes colaboraciones, entre ellas sus Aguafuertes (Cfr. Rose Corral, Roberto Arlt. Una poética de la disonancia, El Colegio de México, México, 2009, p. 12).

${ }^{122}$ En la recuperación y la representación del lenguaje propio de los marginados, como ocurre con el empleo de la palabra cafishio, usada categóricamente en la narrativa de Roberto Arlt, y retomada en el cuento "La loca y el relato del crimen" (el lunfardo como alusión intertextual), Piglia está proponiendo la inclusión de aquellas voces que funcionan para nombrar lo marginal y lo no autorizado. La palabra kelper, que al parecer está conformada por una contracción de un vocablo de una lengua patagona y la terminación inglesa er que funciona para nombrar al que ejecuta una acción, alude a las personas de origen anglosajón que viven en las Islas Malvinas y quienes, hasta antes de la guerra, eran consideradas inferiores a la gente de raza inglesa, 
ofrece un sentido que lo coloca fuera de la nacionalidad argentina pero, simultáneamente, también lo exhibe como un extranjero en su relación periférica con la cultura inglesa; el diálogo con la policía había comenzado con su negativa a considerarse inglés, más bien es hijo de ingleses. La respuesta indeterminada, y su profesión de periodista, posiblemente hayan sido las razones por las que el comisario dejó de lado la pregunta de rutina para preguntarle si sabía que Julia era Artículo 22, o sea, "prostitución callejera” (p. 94), por lo que ella es consignada a las autoridades para que la remitan al hospital neuropsiquiátrico de Avellaneda ya que, supuestamente, su problema es mental, no político.

Si en el caso de El hombre en el castillo el problema del género es tal que inclusive los personajes discuten a propósito de La langosta se ha posado, por lo que cabe interpretar la novela como una ucronía, siguiendo a Eco, en cuanto a La ciudad ausente puede afirmarse algo semejante. Si las acciones se llevan a cabo en un tiempo futuro, este no se encuentra tan alejado de la década de los noventa, cuando se publica la novela por primera vez. Se trata, más bien, de un presente alternativo, de un mundo paralelo donde Macedonio Fernández ha podido construir una máquina con el cuerpo de su esposa Elena, de quien han nacido todos los relatos de la literatura argentina. La puesta en duda de la realidad, frente a

según los comentarios de aquéllos que responden a la pregunta “¿Qué son los kelpers?" (http://es.answers.yahoo.com/question/index?qid=20071020204223AAXbJWn, página consultada el 5 de febrero de 2011, y cuya pregunta inicial, formulada por una adolescente de catorce años, refleja el estado actual del lugar). A partir de la guerra con Argentina, el gobierno británico decidió otorgarles la nacionalidad. En la página web de la Enciclopcedia Britannica este vocablo no figura, aunque sí el término kelp, que es definido como "any of numerous large coastal seaweeds growing in colder seas and belonging to the order Laminariales (about 30 genera) of brown algae. Until early in the 19th century the ash of such seaweeds was an important source of potash and iodine. Giant kelps, of the genus Macrocystis, are rich in minerals and produce algin, a complex carbohydrate (polysaccharide) useful in various industrial processes, including tire manufacture. Algin is added to ice cream before freezing to prevent ice crystallization and is also used as a suspending and emulsifying agent in other food products" (http://www.britannica.com/EBchecked/topic/314499/kelp, página consultada el 5 de febrero de 2011). La ausencia del término kelper puede mostrar las diferencias entre una lengua viva y una lengua controlada por las instituciones. Además, el término con el que Junior se nombra funciona como una prolepsis del relato sobre los hombres marginados asentados en el río Liffey, dentro del metarrelato "La isla", cuya lengua varía tanto en tan poco tiempo que solo el Finnegans Wake de James Joyce (escrito en una lengua inglesa no institucionalizada, sino desautomatizada, codificada y marginal: una literatura menor) puede leerse no sólo como un texto literario, sino como un texto de resistencia política. 
la ficción y la irrealidad, es un recurso tradicional de la literatura fantástica rioplatense, desde Macedonio y Borges. En una entrevista concedida a Guillermo Saavedra, Piglia habla del título de la novela y de la conexión entre la realidad y la ficción: "creo que la novela intenta insinuar esos lugares invisibles sin evocarlos del todo. Por eso trabajé, en este caso sí deliberadamente, con lugares muy precisos y reconocibles de Buenos Aires, para intentar construir algo que era lo contrario del realismo; una suerte de irrealidad, de ausencia, que se manifiesta justamente por aquello que sí está presente"123.

En esta combinación borgiana de realidad e irrealidad, Piglia va más allá y le confiesa a Saavedra, a propósito de los recursos metaficcionales y la literatura fantástica:

-No me va a decir que no es consciente de que la dificultad central del texto pasa por no saber, en muchos momentos, si el relato lo está contando la máquina u otra voz y por ignorar quién es el verdadero destinatario de ese relato.

-No, claro. Es evidente que el libro se juega de tal modo que puede ser leído creyendo que toda la novela, incluso Junior, son un producto de la máquina misma ${ }^{124}$.

123 "Ricardo Piglia. El estado de la novela", en Guillermo Saavedra, La curiosidad impertinente. Entrevistas con narradores argentinos, Beatriz Viterbo, Buenos Aires, 1993, p. 112. Esta afirmación es la certeza de la presencia del género fantástico en la obra de Piglia, ante las dudas de la crítica literaria. Jorge Fornet, por ejemplo, señala: "En La ciudad ausente no sabemos a ciencia cierta si la historia de Junior corre paralela a los relatos de la máquina o si ella misma es un relato más" (Jorge Fornet, op. cit., p. 14).

${ }^{124}$ Ibid., p. 106. 


\title{
2.2. La máquina Elena y sus relatos: metaficción y función política
}

\author{
Reiss cerró el libro y se quedó pensando. Muy a su pesar \\ se sentía perturbado. Tenía que haber presionado más a los japoneses, \\ se dijo, para que prohibieran el maldito libro. La obra, obviamente, \\ estaba de parte de ellos. Hubiera podido arrestar también a... \\ cómo se llamaba... Abendsen. Disponía de poder suficiente en el Medio Oeste. \\ PHILIP K. DICK, El hombre en el castillo \\ La máquina ha logrado infiltrarse en sus redes, \\ ya no distinguen la historia cierta de las versiones falsas. \\ RICARDO PIGLIA, La ciudad ausente
}

El apartado anterior intenta postular que la metaficción es un procedimiento literario que aparece en los textos de dos tradiciones de lo fantástico: la rioplatense y la estadounidense (tradiciones donde las obras de Piglia navegan, cuestionando el canon e incorporando figuras literarias marginales ${ }^{125}$ ); más allá de pensar la metaficción como un práctica esteticista, su finalidad, en las obras de autores tan dispares como Borges, Dick y Piglia, consiste, básicamente, en el cuestionamiento de lo que se entiende por "realidad" y su relación con la ficción. Simultáneamente, y de manera concreta y deliberada en el caso de la narrativa pigliana, la función de la metaficción está relacionada con la crítica social del

\footnotetext{
${ }^{125}$ Frente al lirismo de la prosa de Ray Bradbury en sus narraciones de ciencia ficción (cfr. Umberto Eco, Apocalípticos e integrados, trad. de Andrés Boglar, Lumen-Tusquets, México, 2004, p. 134, donde afirma que este escritor, "en vez de contar historias fantástico-científicas puras y simples, se esfuerza en darles continuamente una apariencia artística, gracias al empleo de un lenguaje explícitamente lírico") y su incorporación al canon gracias a las opiniones de los niveles medio y alto de la cultura (según Eco), como lo ilustra la breve reseña de su obra por parte de Jorge Luis Borges y Esther Zemborain en su Introducción a la literatura norteamericana (Alianza Editorial, Madrid, 1999, pp. 125-126), la figura de Philip K. Dick, como escritor marginal (no incluido en la obra mencionada de Borges y Zemborain) cuya prosa se caracteriza por la ausencia de recursos propios de la "alta cultura" o por la ausencia del lirismo con el que se identifican los textos de Bradbury -sin que se niegue la importancia de Fahrenheit 451-, es valorada y ubicada en un plano de mayor importancia para Ricardo Piglia, tal como se vio en la relación establecida entre La ciudad ausente y El hombre en el castillo.
} 
escritor argentino: mediante los recursos desautomatizadores de la literatura y el poder de la ficción, Piglia contrapone "los relatos sociales" a los relatos del Estado, que intentan mostrar una realidad ficticia. Paradójicamente, las literaturas fantásticas de Borges y Dick niegan la realidad en la que vivimos; Piglia va más allá: emplea la literatura como un modo de protestar ante las intenciones gubernamentales de controlar "el principio de la realidad":

Hay una serie de contra-relatos estatales, historia de resistencia y oposición. Hay versiones que resisten estas versiones. Quiero decir que a estos relatos del Estado se le contraponen otros relatos que circulan en la sociedad. Un contra-rumor diría yo de pequeñas historias, ficciones anónimas, micro-relatos, testimonios que se intercalan y circulan. A menudo he pensado que esos relatos sociales son el contexto mayor de la literatura. La novela fija esas pequeñas tramas, las reproduce y las transforma ${ }^{126}$.

La oralidad de la máquina de narrar, Elena, representa esa función social y política que Piglia señala en su conferencia. Sustituye a los viejos narradores de los pueblos. Tiene razón Edgardo H. Berg cuando establece la conexión entre las ideas de Walter Benjamin, a propósito de su ensayo "El narrador", con la intención de Macedonio Fernández -en La ciudad ausente- de crear una máquina de traducir, que en realidad se convirtió en una máquina de narrar ${ }^{127}$. El recurso de la alegoría, a partir de la ficcionalización de uno de los grandes textos teóricos de Benjamin, cobra un relieve político: Macedonio es visto como el gran autor del complot contra Buenos Aires - como también lo recuerda Berg ${ }^{128}$ - en el proyecto del Presidente de ganar la ciudad para la belleza, pero fracasa y disuelve su grupo

\footnotetext{
${ }^{126}$ Ricardo Piglia, Tres propuestas para el próximo milenio (y cinco dificultades), op. cit., p. 25. El carácter visionario de La ciudad ausente es tal que incluso se adelanta al impacto que unos años después produciría el fenómeno Internet. Para la Doctora Ana Rosa Domenella, estas ficciones anónimas y pequeñas historias podrían pensarse como un anticipo de las redes sociales, sobre todo cuando se emplean de modo político (para ejercer los derechos democráticos), no cuando funcionan como otro modo de enajenación mental.

${ }^{127}$ Edgardo H. Berg, op. cit., pp. 85 y 88.

${ }^{128}$ Ibid., pp. 94-96.
} 
de seguidores ${ }^{129}$. Como un modo de reparar su fracaso ante la imposibilidad de lo que ensayó en Museo..., Fernández, en La ciudad ausente, con la ayuda del ingeniero Russo, crea una máquina capaz de resistir los relatos manipuladores del Estado. Mostrando a Macedonio como un escritor vanguardista y subversivo, Piglia lo incorpora a la órbita de la resistencia popular ${ }^{130}$, tal como años atrás lo había hecho con Borges en el ensayo "Ideología y ficción en Borges".

Cruzar a Macedonio con Benjamin puede ser otro modo, posterior a los binomios aparentemente antitéticos Borges-Arlt y Joyce-Kafka de Respiración artificial, de unir distintas tradiciones e ideologías. La figura del artista de vanguardia que renueva los modos de escribir y de leer, Macedonio Fernández, el autor con el que empieza la genealogía literaria de la temática de la ciudad -a la par de las novelas de Roberto Arlt: El juguete rabioso, Los siete locos y Los lanzallamas- y con el que empieza la poética de lo fantástico en el Río de la Plata en el siglo $\mathrm{XX}^{131}$, y la presencia implícita de uno de los teóricos que

${ }^{129}$ Macedonio Fernández, Museo de la Novela de la Eterna (Primera novela buena), Obras completas, v. 4, Corregidor, Buenos Aires, 2010.

${ }^{130}$ En un diálogo entre Junior y uno de sus contactos, Ana, la hija de Macedonio, se establece la figura del autor del Museo de la Novela... como un outsider y un disidente. Piglia remite implícitamente a la escena final de Fahrenheit 451, cuando Montag, el bombero disidente, consigue cruzar el río y llegar a las vías donde los profesores universitarios y los poetas se han refugiado, esperando una señal para recuperar el mundo: "Muchos se están escapando al campo. Ya no al sur, el valle, sino la pampa misma. Levantan una tapera y siembran, se conectan por radio. Se mueven de un lado a otro. Andan con esos autos destartalados, tienen receptores de onda corta. Difícil encontrar a un tipo que se esconde en la llanura pelada. Los viejos crotos hacían eso. Anarquistas, filósofos, místicos, cuando vino la mano dura, se largaron a la vía, linyeras -dijo después-, Macedonio anduvo también por esos campos. Llevaba una libretita y escribía sus cosas” (p. 105). Cfr. Ray Bradbury, Fahrenheit 451, trad. de Alfredo Crespo, Random House Mondadori, México, 2008 (Debolsillo).

${ }^{131}$ En un ensayo sobre el autor de Final del juego, Ricardo Piglia enumera aquellas novelas argentinas que pertenecen a una tradición de lo urbano -y en algunos casos de lo fantástico-: Los siete locos, Museo de la Novela de la Eterna, Adán Buenosayres, Rayuela y El sueño de los héroes. "El Aleph" también se hace presente por ser otro texto de gran influencia. Cfr. Ricardo Piglia, "Homenaje a Julio Cortázar", Casa de las Américas, año XXXVI, núm. 200, julio-septiembre de 1995, pp. 98-99, y Jorge Fornet, "Escritura, memoria y complot", El escritor y la tradición, op. cit., pp. 169-174. Por otro lado, la presencia de Leopoldo Lugones también es visible en sus cuentos modernistas, que desplegarán una poética de lo fantástico. Ejemplos de lo anterior son "La lluvia de fuego" y "Un fenómeno inexplicable". Este último relato forma parte de las viñetas de La Argentina en pedazos, el volumen de historietas coordinado y escrito por Ricardo Piglia (Ediciones de la Urraca, Buenos Aires, 1993 (Col. Fierro)). Hacia atrás, en el siglo XIX, otro antecedente de lo fantástico rioplatense se encuentra en "La novia del muerto" de Juana Manuela Gorriti. 
recupera el marxismo para emplearlo en los medios de comunicación -como el cine- para que sean instrumentos de la revolución antiburguesa, Walter Benjamin ${ }^{132}$, es un modo de conciliar la vanguardia con la revolución, en la línea teórica de Bertolt Brecht. En “El narrador", Benjamin advierte: "Rara vez se toma en cuenta que la relación ingenua del oyente con el narrador está dominada por el interés de conservar lo narrado", lo que implica que la función del escritor, desde lo social, es recuperar los relatos orales de la experiencia para reproducirlos a los lectores: "el punto cardinal para el oyente sin prejuicios es garantizar la posibilidad de la reproducción. La memoria es la facultad épica que está por encima de todas las otras"133. En La ciudad ausente, el invento de Macedonio resulta "muy útil porque los viejos que a la noche, en el campo, contaban historias de aparecidos se iban muriendo" (p. 42). Más allá de la obra del escritor, el relato se perpetúa a través de la narración oral que la máquina disemina en la novela y en todo el espacio de la ficción, más allá de Buenos Aires, del Tigre, del Delta y del Liffey que pasa por la isla del final de la novela. Las múltiples versiones de los relatos contados por la máquina -y las versiones que Piglia, en sus libros, cuenta y vuelve a contar, como el caso de la mujer que abandona a su marido y va al casino-, junto con sus recursos de desautomatización, empleados para renovar las lecturas y diferenciarse de los relatos del Estado, son la representación de la resistencia social. En Tres propuestas para el próximo milenio (y cinco dificultades), conferencia que une la visión estética de Italo Calvino con la mirada combativa de Brecht $^{134}$ (lo que vuelve a producir esos cruces representados a través de un autor de

\footnotetext{
${ }^{132}$ Walter Benjamin, "La obra de arte en la época de su reproductibilidad técnica", Estética y política, trad. de Tomás Joaquín Bartoletti y Julián Fava, pról. de Ralph Buchenhorst, Las Cuarenta, Buenos Aires, 2009.

${ }^{133}$ Walter Benjamin, "El narrador", Para una crítica de la violencia y otros ensayos, Taurus, Madrid, 1991, p. 124.

134 "He querido imaginar entonces tres propuestas [alusión al título del libro de Calvino, tal como Piglia lo dice al principio de su conferencia] y cinco dificultades. Y las cinco dificultades remiten a otro texto programático, digamos, irónicamente programático y político, que yo quiero recordar aquí: me refiero al
} 
vanguardia con otro autor de ruptura, aunque más preocupado por cuestiones de índole social que por aspectos formales), Piglia postula, en lo que podríamos llamar una suerte de manifiesto estético-político-social-moral, la labor del escritor. A través de sus novelas, y de modo alegórico en La ciudad ausente, con el personaje de Junior como detective que busca conocer las razones por las que el Estado quiere desactivar la máquina y que sigue los rastros de sus relatos clandestinos, el escritor argentino sugiere una poética de la resistencia civil ante los intentos de los gobiernos por negar la realidad. El papel social del escritor, y de modo particular, de un escritor como Piglia, que se define como un escritor de ruptura, consiste en "establecer dónde está la verdad, actuar como un detective, descubrir el secreto que el Estado manipula, revelar esa verdad que está escamoteada"135.

Pensando la literatura de Piglia desde la semiótica pragmática, y en la línea teórica trazada en este apartado, el análisis estructural de La ciudad ausente pone atención especial a los procedimientos narrativos. Además de la combinación de géneros como el policial, la ciencia ficción y el fantástico, la historia central se encuentra cruzada por múltiples historias que suponen la novela como un texto, como un tejido de relatos y de citas que exhibe una trama compleja, difícil de descodificar, y que sugiere, en este sentido, los modos imaginativos para evitar la censura. El Estado represivo que se lleva a Julia al hospital psiquiátrico y que vigila la conducta de todos los ciudadanos no tiene manera de comprender los relatos de la máquina, ya que su estructura metadiegética produce, hasta

ensayo del escritor alemán Bertolt Brecht que se llama Cinco dificultades para escribir la verdad" (Ricardo Piglia, Tres propuestas..., op. cit., p. 14). Este nuevo cruce tiene la finalidad de hablar de la poética, las obras y las acciones de resistencia de Rodolfo Walsh.

${ }^{135}$ Ibid., p. 21. 
cierto punto, una confusión que ya no crean los textos convencionales y realistas, opuestos a la tradición poética que viene de Macedonio y $\operatorname{Arlt}^{136}$.

La máquina, que el Estado ha podido adquirir una vez que Macedonio ha muerto ${ }^{137}$, es ubicada en un museo para institucionalizarla y producir la apatía de los ciudadanos: “El Museo detrás del Congreso, donde se halla la máquina, no es el archivo oficial de la memoria, no es el lugar de la tradición, donde se conservan textos y documentos que el Estado ha querido guardar para preservar cierta versión del pasado"138.

Sin embargo, la estructura metadiegética y sus relatos metaficcionales no son lo que le preocupa al gobierno y sus instituciones, sino que la máquina, al empezar a narrar los modos en que fue inventada y los intentos del aquellos por callarla, comienza a contar su persecución, por lo el Estado decide apagarla, o sea, suprimirla. "Ha empezado a hablar de sí misma. Por eso la quieren parar" (p. 106), le dice Ana Fernández a Junior.

La función metalingüística del lenguaje, analizada por Roman Jakobson en su ensayo "Lingüística y poética"139, indica el énfasis de la oración puesto en sí mismo; la paradoja, como figura lógica, también expresa su autorreferencialidad ${ }^{140}$; a su vez, Lucien Dällenbach, teórico que será analizado con detenimiento en el capítulo tercero de esta tesis, dedicado a la nouvelle "Encuentro en Saint-Nazaire", estudia los elementos propios de la

\footnotetext{
${ }^{136}$ Sobre la cambiante disposición de los textos piglianos, a propósito de los juegos que el escritor argentino emplea al sacar los textos de su contexto original -como ocurre con "El fluir de la vida", cuento sacado de la nouvelle "Prisión perpetua"-, me remito al tercer capítulo de esta tesis, donde analizo "Encuentro en SaintNazaire" dentro del género de la nouvelle fantástica y dentro del corpus de los Cuentos morales, antología donde figura como texto independiente, alejado de su complemento "Diario de un loco".

${ }^{137}$ Una vez creada la máquina, Macedonio se mantiene alejado de la intromisión gubernamental: "Pensaba perfeccionar el aparato (lo llamaba así) con la intención de entretener a los paisanos en los pueblos. Me parece un invento más divertido que la radio, decía, pero todavía es prematuro cantar victoria. Pedía discreción y se negaba a aceptar el apoyo del gobierno" (p. 42).

${ }^{138}$ Edgardo H. Berg, op. cit., p. 85.

139 Roman Jakobson, "Lingüística y poética", en Nara Araújo y Teresa Delgado (selec. y apuntes introductorios), Textos de teorías y crítica literarias (Del formalismo a los estudios coloniales), Universidad de la Habana/UAM-I, México, 2003.

${ }^{140}$ Cfr. Patrick Hughes y George Brecht, "Círculos viciosos e infinitud", Revista de Occidente (Madrid), tercera época, núms. 5 y 6, marzo-abril de 1976, pp. 90-94.
} 
mise en abyme en las obras de arte que se refieren a sí mismas o que contienen otras obras dentro de ellas ${ }^{141}$. En los tres casos mencionados, cuando estos recursos aparecen en una novela, una pintura o un filme, por ejemplo, se produce una especie de ruptura y se crea la sensación de confusión en los receptores: la obra no habla de otra cosa más que de sí misma, lo que permite imaginar una especie de agotamiento temático, como visualizó John Barth a propósito de la literatura de Borges que, por lo demás, plantea una serie de ideas filosóficas que niegan o cuestionan la "realidad" mediante procedimientos literarios como la metaficción o figuras lógicas como la paradoja y la ironía ${ }^{142}$.

En esta línea de la tradición literaria, las obras narrativas de Piglia tienen una de sus bases formales y temáticas. Sin embargo, su empleo de la metaficción es una suerte de síntesis de cierto procedimientos estéticos y de su propuesta política: partiendo de una poética de la renovación, de acuerdo con el concepto de evolución literaria, analizado por el formalismo ruso, la práctica metaficcional en Piglia plantea cierta deuda formal con Borges pero, al mismo tiempo, emplea dicha práctica para explorar la función social de la literatura. Frente a una narrativa realista, sencilla para la lectura de un público consumidor, como el que leía las novelas históricas de Manuel Mujica Lainez ${ }^{143}$, la literatura metaficcional, de corte fantástico, marca una ruptura con los modos convencionales de leer, que son los mismos que el Estado emplea para divulgar su mentalidad y su ideología, acorde con el proyecto neoliberal de la globalización económica. En ese sentido, el

\footnotetext{
${ }^{141}$ Lucien Dällenbach, op. cit.

142 John Barth, "Literatura del agotamiento", en Pablo Brescia y Lauro Zavala (comps.), Borges múltiple. Cuentos y ensayos de cuentistas, UNAM, México, 1999 (El Estudio).

143 "Me gustan los primeros libros de Mujica Lainez [...] Luego empezó a escribir novelas históricas, una sucesión anual de pastiches pseudorrefinados y preferentemente egipcios que nosotros - hablo de los escritores de mi generación- mirábamos con cierta ironía" (Jorge Carrión, "No hay que tomarse en serio a ningún escritor. Entrevista con Ricardo Piglia”, en Jorge Carrión (comp., pról. y ed.), El lugar de Piglia. Crítica sin ficción, Candaya, Barcelona, 2008, pp. 429-430). Para mi tutora, la doctora Domenella, Mujica Lainez es un escritor típicamente burgués, lo que explica el comentario que Piglia le hace a Carrión en la entrevista, derivado de su ataque, a través de Renzi, en Respiración artificial.
} 
proyecto literario de Macedonio Fernández, antecesor del de Borges, es también subversivo en la medida de que su oposición a la tradición realista deviene en una poética de lo irreal y lo fantástico como una manera de provocar otro efecto de lectura y de proponer un modelo revolucionario estético y político. La ciudad ausente, como Respiración artificial, es una novela que indaga en la tradición literaria y que intenta fijar otros modos de leer: la máquina de Macedonio, creada para prolongar la memoria de los pueblos, y que también cumple la función de traducir textos de lenguas extranjeras, es la matriz de donde sale toda la literatura posterior, argentina y mundial. En uno de sus giros habituales, que causan tanta polémica e indignación en sus detractores, Piglia afirma, a propósito de la alegoría de la máquina de narrar de Macedonio:

\footnotetext{
Yo trabajé con la idea de que esa máquina existe. Y en un sentido, creo que la máquina es real y que no he hecho otra cosa que una novela de no ficción. Y tengo la sospecha de que hay una convención por la cual nadie se refiere a esa máquina porque eso pondría en crisis ciertos textos de la literatura argentina. Si uno hablara realmente de la máquina de Macedonio, tendría que aceptar que los cuentos de Borges, entre muchas otras cosas, son resultado de esa máquina ${ }^{144}$.
}

El linaje literario de vanguardia comienza con Arlt y Macedonio, figuras literarias emblemáticas de la renovación literaria y de la resistencia ante el fascismo, entendido este como parte de la ideología y las acciones de un gobierno dictatorial o un gobierno neoliberal que simula ser democrático y progresista.

La metaficción funciona, precisamente, como un acto subversivo que reflexiona, además, sobre los nuevos modos de recepción y los intentos de salir de una visión del mundo construida artificialmente por el Estado. Esa literatura convencional, que simplemente narra historias sin ningún intento reflexivo, y que mucho menos se pregunta

\footnotetext{
${ }^{144}$ Guillermo Saavedra, op. cit., p. 103.
} 
sobre el sentido de la literatura y la lectura en un espacio narrativo como la novela, la nouvelle o el cuento, es la literatura realista que busca mostrarse como espejo de la realidad. Por eso, los procedimientos metaficcionales rompen con la pobre noción que las autoridades gubernamentales tienen de la literatura, como ocurre con Arocena en Respiración artificial. Puede salirse del espacio oficial, de carácter político, y del espacio canónico de las instituciones literarias mediante el empleo de la metaficción, la parodia, la cita "erróneamente" atribuida, la alusión a un libro apócrifo, etcétera. Estos recursos, característicos de la literatura pigliana, ponen de manifiesto una literatura renovadora y desautomatizadora que rompe con los moldes de una literatura tradicionalista -en el mal sentido del término-. El género discursivo del diálogo literario entre dos o más personajes de una novela de Piglia es también un recurso poético que busca reflexionar sobre la literatura dentro de la literatura, sin que necesariamente se deba recurrir al género ensayístico para exponer opiniones e ideas. La mirada conservadora que no admite estos juegos literarios que, por lo demás, no sólo atienden aspectos estéticos, como he mencionado arriba, sino también cumplen con una función política, rechaza todo esfuerzo intelectual que propicie la evolución literaria: “¿Metaliteratura? En España todavía la mandan a la Inquisición"145, afirma Enrique Vila-Matas. Si los medios masivos de comunicación, como nos recuerda Umberto Eco, se han apropiado de las técnicas, los recursos y los procedimientos de los productos de la alta cultura para re-producirlos con fines cercanos a ilusionar -en el doble sentido- a los consumidores de que están adquiriendo un producto culto cuando en realidad se trata de algo que incluso llega a degradarse en lo kitsch ${ }^{146}$ y a consumirse, la función social y política consiste en emplear

\footnotetext{
${ }^{145}$ Enrique Vila-Matas, “Descifrar el arte de narrar”, en Jorge Carrión, El lugar de Piglia, op. cit., p. 362.

${ }^{146}$ Umberto Eco, op. cit., pp. 59 y 113.
} 
las técnicas, los recursos y los procedimientos de un modo todavía más vanguardista para continuar propiciando la evolución literaria. Frente al escritor conformista y convencional que a su vez tiene un público convencional, Vila-Matas piensa en la figura de un autor como Piglia, cuya obra es una revisión permanente de lo que se entiende por literatura, en diálogo con formas de leer más intelectuales y revolucionarias:

En oposición a estos lacayos del mercado, a estos neopopulistas de la cultura de masas, va emergiendo una tradición culta y con gusto por el complot y por lo clandestino que rechaza la inocencia narrativa y comparte la certeza de que el mundo ya ha sido narrado, pero que el misterio de la escritura permanece y exige todavía una nueva vuelta de tuerca y nuevas formas y estructuras para $\operatorname{las~novelas~}^{147}$.

De este modo, las referencias cultas diseminadas a lo largo y lo ancho del mapa narrativo de los textos de Piglia responden a un diálogo con la tradición literaria, pero también promueven la reflexión sobre la creación artística como una actividad social que intenta colaborar en la búsqueda de un movimiento incluyente, tolerante, crítico y capaz de salir de la mentalidad propia del neoliberalismo económico y de los disfraces que emplea.

En el contexto de ese gesto vanguardista que Vila-Matas y Piglia encuentran en las "nuevas formas y estructuras de las novelas", y en la línea de Macedonio y Borges, la presencia de Junior en el Museo es una escena similar a la que vive el Borges personaje de “El Aleph”, ya que el periodista observa escenas múltiples de diversas literaturas: desfilan textos, reproducciones y representaciones de escenas de Los lanzallamas (el suicidio de Erdosain en el tren ${ }^{148}$ ), Bajo el volcán, la daga de Moreira que remite al texto Juan Moreira de Eduardo Gutiérrez, la figura de Macedonio en su pieza de Tribunales... Además de este

\footnotetext{
${ }^{147}$ Enrique Vila-Matas, op. cit., pp. 363-364.

148 Roberto Arlt, Los siete locos. Los lanzallamas, ed. crít. de Mario Goloboff (coord.), FCE/ALLCA XX, París, 2000 (Archivos, 44).
} 
canon que obliga a la crítica literaria a establecer relaciones entre los textos de Piglia con las obras mencionadas, aparecen otros, contados por la máquina, sin autor, que corresponden a nuevas variantes de viejas versiones ${ }^{149}$, con distintos modos de narrar, donde se sugiere el diálogo implícito entre la tradición popular anónima, de carácter oral, la escritura culta, el canon oficial y las obras de autores que en algún momento fueron marginadas de la escena literaria central. En el cruce de los textos de la tradición con los relatos creados por la máquina -que sugieren, además, la presencia de lo apócrifo y su paulatina invasión sobre los textos "reales"-, se produce un giro semiótico que busca anular las percepciones de la realidad: "Junior vio el cuarto de hotel de Cuernavaca, con la cama envuelta en un mosquitero y la botella de tequila. En una sala lateral estaba la pieza del Majestic y el ropero donde la mujer había buscado el frasco de perfume. Lo asombraba la fidelidad de la reconstrucción. Parecía un sueño. Pero los sueños eran relatos falsos. Y éstas eran historias verdaderas" (p. 49). La primera descripción corresponde a la novela de Lowry, si bien parece que se trata de una escena apócrifa que la máquina ha registrado de modo extraño: en el hipotexto, la habitación del hotel de Cuernavaca y la botella de tequila son rasgos identificables con los que Piglia elabora el material temática del Museo, pero el mosquitero está fuera de lugar ${ }^{150}$; la segunda descripción corresponde a una escena intratextual, ya que Junior llega al Museo para entrevistarse con Fuyita: la mujer que lo condujo hasta él fue Lucía Joyce, la cantante loca encerrada en la habitación del hotel. Ambas escenas, enmarcadas en habitaciones de hotel donde los huéspedes consumen

\footnotetext{
${ }^{149}$ Por citar dos ejemplos: "Una mujer" remite a los diarios de Chéjov; "La nena" indaga en el motivo del anillo y de la estatua que cobra vida.

${ }^{150}$ Malcolm Lowry, Bajo el volcán, trad. de Raúl Ortiz y Ortiz, Era, México, 2008.
} 
alcohol, es una referencia metaficcional, intertextual ${ }^{151}$ y fantástica: lo que acaba de ocurrir minutos antes ya estaba fijado por el Museo y por la creadora: la máquina Elena. El siguiente giro que termina por sembrar la inestabilidad narrativa y por alterar la percepción de lo real, se encuentra en la afirmación del narrador sobre la autenticidad de los relatos. En unos cuantos renglones, Piglia sugiere el poder de la literatura fantástica al confundir las nociones occidentales de "realidad" e "imaginación" (ficción), ofreciendo, incluso, una escena apócrifa de un libro y un autor reales, lo que coloca esta práctica fantástica en la línea teórica desarrollada por David Roas:

El mundo construido en los relatos fantásticos es siempre un mundo en el que inicialmente todo resulta normal y que el lector identifica con su propia realidad. Y no me refiero aquí simplemente a la presencia del texto de datos provenientes de la realidad objetiva [...] Más allá de esas referencias, reconocibles por el lector y que aseguran una evidente ilusión de realidad, lo verdaderamente importante es que la construcción del mundo textual va destinada a demostrar que éste funciona de un modo idéntico al real. Un funcionamiento aparentemente normal que, de pronto, se verá alterado por la presencia de lo sobrenatural, es decir, por un fenómeno que contradice las leyes físicas que organizan dicho mundo. Esto es lo que lleva a los lectores a abandonar el estricto ámbito de lo textual y asomarse a su propia realidad [...] para interpretar el verdadero sentido de la historia narrada: si el mundo del texto, que funciona como el nuestro, puede verse asaltado por lo inexplicable, ¿podría llegar a suceder en la realidad? Ése es el gran efecto de lo fantástico: provocar $-\mathrm{y}$, por tanto, reflejar- la incertidumbre de la percepción de lo real ${ }^{152}$.

\footnotetext{
${ }^{151}$ Las referencias intertextuales de escenas de hotel -además de las intratextuales- apuntan, por un lado, al género negro; por otro, de modo particular, el Hotel Majestic es elegido por Piglia como uno de los espacios de la ficción porque remite al célebre sitio donde Ricardo Güiraldes hacía sus tertulias literarias. Algunas veces, su amigo Roberto Arlt hizo acto de presencia (cfr. Rose Corral, op. cit., p. 40). Resulta emblemático que dos espacios ficcionales en La ciudad ausente, la redacción de El Mundo y el Majestic, al inicio de la novela, aludan a la figura del autor de El jorobadito, lo que sugiere que la presencia de Arlt es incuestionable en una novela que trabaja y une sofisticadamente los llamados géneros marginales. La presencia de Güiraldes también resulta significativa: mencionar el Majestic como ese famoso sitio de las tertulias organizadas por el autor de Don Segundo Sombra anuncia uno de los primeros relatos de la máquina que conoce Junior y que los lectores leemos por primera vez: "El gaucho invisible". El Tape Burgos, protagonista de este relato, es un personaje de la novela de Güiraldes. (Para el análisis de los dos textos dentro de la tradición de la literatura gauchesca, cfr. Ana María Barrenenechea, "Inversión del tópico del beatus ille en La ciudad ausente", en Adriana Rodríguez Pérsico, Ricardo Piglia: una poética sin limites, Universidad de Pittsburgh, Pittsburgh, 2004 (Serie Antonio Cornejo Polar), pp. 85-99.

${ }^{152}$ David Roas, op. cit., pp. 39-40.
} 
Tomando en cuenta la aseveración de Roas, puede afirmarse que la escena citada arriba muestra, por un lado, la herencia de la tradición que inicia con Macedonio y Borges; por otro lado, en la selección de escenas tomadas de autores considerados anteriormente como marginales, refleja la toma de posición por una literatura de ruptura que al mismo tiempo es subversiva y llega a los linderos de la clandestinidad. La presencia de Junior no sólo como espectador, sino como sujeto partícipe en las acciones, representado por la máquina en esa sala lateral (sala "marginal" y humilde frente a la representación de las narraciones de Arlt y Lowry), lo ubica al lado de los outsiders, del lado de los perseguidos como Erdosain, Geoffrey Firmin y Juan Moreira. La relación que establece con sus contactos (Russo, Julia, Ana Fernández, Fuyita) y su labor periodística, en busca de información "real", lo convierten en un sujeto sospechoso, vigilado por la policía.

Junior continúa su investigación y se prepara a leer el relato que Fuyita le había entregado en un sobre, "Los nudos blancos": "Una historia explosiva, las ramificaciones paranoicas de la vida en la ciudad. Por eso hay tanto control, pensó Junior, están tratando de borrar lo que se graba en la calle. La luz que brilla como un flash sobre las caras lívidas de los inocentes en la foto de los prontuarios policiales" (p. 65; cursivas mías). Esta historia es explosiva en más de un sentido, por supuesto; por un lado, es "uno de los relatos de la máquina, o quizás el último" (p. 61), lo que supone su estructura metaficcional, ya que lo leemos dentro de la novela y nos remite a otras historias; su carácter metadiegético, al momento de leerlo, produce un estado vertiginoso, como lo sugiere Stephen Albert en "El jardín de senderos que se bifurcan”"153. Además, el adjetivo explosiva, empleado por el

\footnotetext{
153 “[...] yo me había preguntado de qué manera un libro puede ser infinito. No conjeturé otro procedimiento que el de un volumen cíclico, circular. Un volumen cuya última página fuera idéntica a la primera, con
} 
narrador, indica, evidentemente, su naturaleza rizomática (siguiendo a Edgardo H. Berg ${ }^{154}$ ).

Por otra parte, el término alude a un acto de rebeldía y subversión: explotar el orden social represivo mediante una obra radical, literaria o anarquista.

"Los nudos blancos" es el relato donde Elena Fernández figura como protagonista. El título, que remite a la idea de una estructura circular e infinita (“Todo volvía a empezar” (p. 80)), es tomado de las formas interpretadas como signos de los caparazones de las tortugas de un acuario de Buenos Aires. Según Borges, el I Ching también proviene de "la caparazón de una de las tortugas sagradas" $" 155$ de la época de un emperador primitivo (lo que vuelve a mostrar ciertos hilos conductivos entre Borges y Dick, en la novela de Piglia). La estructura narrativa no se funda en la certeza de los hechos contados sino en la ambigüedad, por lo que se producen diferentes interpretaciones: Elena es una máquina controlada por el doctor Arana (cuyo aspecto es suficiente para pensar que él hace "reales todos los delirios" (p. 66)) o es una mujer que intenta escapar con El Tano ("El mejor técnico en explosivos que habían tenido nunca" (p. 74)) o es el sueño de la fotógrafa del Museo, Grete Müller. En todo caso, el relato ha pasado de las manos de Fuyita (quien

posibilidad de continuar indefinidamente. Recordé también esa noche que está en el centro de las 1001 Noches, cuando la reina Shahrazad (por una mágica distracción del copista) se pone a referir textualmente la historia de las 1001 Noches, con riesgo de llegar otra vez a la noche en la que refiere, y así hasta lo infinito" (Jorge Luis Borges, "El jardín de senderos que se bifurcan”, op. cit., pp. 111-112). En La ciudad ausente, la sala del Museo es circular (como los laberintos borgianos) y se hacen varias referencias a la narradora de las 1001 noches, por lo que se establece, de esta manera, una genealogía metaficcional con toda una tradición literaria de lo fantástico.

${ }^{154}$ En una nota a pie de página, Berg aclara la procedencia del concepto de rizoma y lo relaciona con la novela de Piglia: "La distribución narrativa de La ciudad ausente en relatos-pistas o relatos-mapas puede pensarse en relación con las palabras-valija -relatos-valija diría a propósito de la novela de Piglia- de Gilles Deleuze. Deleuze [...] dice: la función de la palabra-valija consiste siempre en ramificar la serie en la que se inserta. Nunca existe sola: llama a otras palabras valija que la preceden o la siguen, y que hace que toda serie esté ya ramificada en principio y sea todavía ramificable" (Edgardo H. Berg, op. cit., p. 86). Por su parte, la doctora Ana Rosa Domenella también comprende la estructura de la novela como un rizoma que se desdobla heteróclitamente. Dentro de la tradición de la teoría del estructuralismo, los estudios intertextuales de Gérard Genette y el concepto de texto de Roland Barthes ("un texto es un tejido de citas provenientes de los mil focos de la cultura": "La muerte del autor", en Nara Araújo y Teresa Delgado, op. cit., p. 343), también son pertinentes.

${ }^{155}$ Jorge Luis Borges, “Sobre los clásicos”, Nueva antología personal, Siglo XXI, México, 1998, p. 225. 
también figura en aquél: es el coreano que les abre las puertas del Museo a Elena y El Tano y los guía a Mac[edonio]) que, a su vez, lo ha fotocopiado (duplicado) para entregárselo a Junior, en un acto clandestino que incluye los aparatos tecnológicos como parte de la resistencia y juega con las leyes de los derechos de autor. Habla de la instalación de una memoria artificial ${ }^{156}$, de la adicción como tratamiento psiquiátrico para deshacerse de los rebeldes y de la búsqueda de Mac, uno de los rebeldes más peligrosos. En realidad, la máquina Elena está hablando de sí misma y de sus modos de operar. Este relato clandestino también es buscado por la policía para ser destruido, ya que además propone la salida de los perseguidos hacia una isla utópica, del otro lado del río Liffey.

La puesta en abismo de un relato surgido por la máquina de narrar, en el Museo, y que tiene como uno de los espacios de la ficción el propio Museo, produce un vértigo narrativo donde se confunden los relatos de las tradiciones literarias con los relatos generados por Elena:

Los pabellones se extendían durante kilómetros, con vitrinas que exhibían el material del pasado. Elena vio la pieza de una pensión de Tribunales y en una silla baja vio a un hombre pulsando una guitarra. Vio a dos gauchos que cruzaban a caballo la línea de fortines; vio a un hombre que se suicidaba en el asiento de un tren. Vio una réplica del consultorio de Arana y vio otra vez la cara de su madre. El Tano la abrazó. También eso lo había visto. El Tano la abrazaba en la sala de un Museo. Vio la réplica del escenario iluminado con Molly Malone cantando con voz de gata el coro de Ana Livia Plurabelle (p. 77).

\footnotetext{
156 "Existe una cierta relación entre la facultad telepática y la televisión [...] el ojo miope y torpe de la cámara graba y transmite los pensamientos reprimidos y hostiles de las masas convertidos en imágenes. Ver televisión es leer el pensamiento de millones de personas" (p. 63). Este procedimiento es el empleado por Arana, ya que, cuando Elena, en posición horizontal y conectada a una pantalla que transmite e ilustra sus pensamientos, se encuentra pensando, Arana la interrumpe con una pregunta que evidentemente le dice que ha llegado hasta lo más profundo de lo que ella quería ocultar: el paradero de Macedonio. La estrategia de espionaje se hace masiva, ante lo cual Berg capta la idea política subyacente: "En la novela no deja de manifestarse la influencia de una televisión narcotizante que anticipa y reproduce los pensamientos de sus espectadores. Contra el criterio estandarizado de los masmediático, la novela de Piglia es un homenaje al poder de la ficción, una defensa de las naturalezas falsas y los mundos posibles" (Edgardo H. Berg, op. cit., p. 95).
} 
Réplica de la visita a Junior al Museo, donde también un coreano (o un japonés) aparece como guía, este fragmento de "Los nudos blancos" refuerza la estructura rizomática de la historia, que se ramifica -o explota- en otras. Este Aleph pigliano incluye la figura física de Macedonio tocando la guitarra, la escena final de Martín Fierro, el suicidio de Erdosain (nuevamente; ¿infinitamente?), el consultorio de Arana (que Elena ya había visitado y donde, posiblemente, en ese momento se encuentra, confundida por las drogas y la ilusión que el médico fascista ha creado para espiar su mente), la cara de su madre (que también había recordado al entrar al consultorio de Arana), el abrazo de El Tano (visto del mismo modo en que Junior se vio reflejado en la habitación del Majestic) y la referencia al Finnegans Wake de James Joyce. Esta enumeración permite un acercamiento intratextual con la escena de la visita de Junior al Museo. Se trata de una variante, donde se juntan varias tradiciones y genealogías literarias (Macedonio y Arlt, insustituibles, se encuentran mencionados en ambas ocasiones): puede unirse, a la figura de Juan Moreira, la figura de Martín Fierro, que en el Museo representan la literatura decimonónica que inaugura los temas "sobre el valor criollo y la violencia" y que desembocan en el siglo XX con la clausura del tema en los cuentos de Borges ${ }^{157}$. Asimismo, la literatura en lengua inglesa aparece representada, primero, por la novela de Malcolm Lowry, Bajo el volcán; después,

\footnotetext{
${ }^{157}$ Josefina Ludmer, "Los escándalos de Juan Moreira", en Josefina Ludmer (comp.), Las culturas de fin de siglo en América Latina, Beatriz Viterbo Editora, Rosario, 1994 (Estudios Culturales), p. 111. Para Ludmer, el texto de Gutiérrez es una continuación de la primera parte (la "ida") de Martín Fierro (Ibid., p. 102), lo que reforzaría la dualidad de las dos escenas del Museo. Paralelamente, la mención de "la larga daga de Moreira sobre un almohadón de terciopelo negro" en La ciudad ausente (p. 49) no sólo permite su relación con el texto de Gutiérrez, sino también con algunos cuentos de la serie de cuchilleros de Borges que reflejan el lado popular de su poética, en oposición a sus relatos "cultos". El cuento "Juan Muraña" puede relacionar a este personaje con Juan Moreira (cfr. El informe de Brodie, Alianza Editorial, Madrid, 2008) como héroe popular y justiciero. Todo lo anterior sería, además, una variante del tema desarrollado por Emilio Renzi en su diálogo con Marconi en Respiración artificial. ¿Por qué Borges no aparece, de modo directo, en estas genealogías? Quizá Piglia ya respondió en la entrevista con Saavedra.
} 
se alude a Finnegans Wake a través del canto de Molly Malone (que por supuesto también remite al Ulysses) sobre Anna Livia Plurabelle. "Con estos materiales - dice el narrador que sigue de cerca a Junior- se habían elaborado las historias" (p. 49). La literatura argentina cruzada múltiplemente por los textos populares de raíz oral, los textos cultos y vanguardistas de Macedonio y su sucesor Borges, la literatura como una provocación a la burguesía y las buenas costumbres escritas en Roberto Arlt, la literatura anglosajona (inglesa, irlandesa, escocesa, y estadounidense) que también es una fuente fecunda para Ricardo Piglia.

Cabe señalar que el análisis anterior no tendría gran importancia si no se piensa la poética de Piglia -y las citas y alusiones anteriores- desde el enfoque de la semiótica pragmática: ¿cómo funcionan esta red de referencias en la literatura de Piglia? La respuesta podría ser: como un modo de producir cambios en la recepción, a propósito del canon instaurado desde la época de Arlt. Contra las pretensiones europeizantes de los integrantes del grupo Sur y contra la incomprensión de los detractores de la obra de Joyce en el Reino Unido, Piglia destaca la participación del perseguido, del outsider (como Junior, hijo de ingleses, en la única ocasión en que no es Renzi quien cumple el rol de detective) como detonante de la causa revolucionaria, al lado de la figura del científico Russo. De este modo, la máquina de narrar crea una literatura que indaga intensa y proporcionalmente en la estética y la política, como querían Bertolt Brecht y Walter Benjamin.

En esta línea crítica donde la novela que nos ocupa posee una estructura metaficcional y rizomática que propone una lectura múltiple, la importancia de lo fragmentario sobre lo totalizador resulta de importancia. Si arriba mencionaba que la estética vanguardista de Macedonio Fernández, que Borges y Piglia recuperan para salir de la poética realista (esa estética que se limita a mostrar "la vida"), es una base de la poética pigliana, también hay 
que tomar en cuenta la estructura fragmentaria, que funciona como un sitio de desautomatización frente a los relatos convencionales y como una especie de ruptura política con las autoridades gubernamentales y sus relatos estatales: para Francine Masiello, la propuesta literaria de Ricardo Piglia puede entenderse en su relación con la resistencia política mediante el procedimiento de lo fragmentario y el concepto de "traducción", tan importante en su obra:

Piglia [...] analiza la temática de la literatura traducida en términos de confrontación con los objetivos del Estado. Las literaturas marginales tienen su propia capacidad de irreverencia, insiste Piglia; de allí surgen sus posibilidades para transformar el arte desde la periferia, de proponer paradigmas de lectura diferentes que eludan las demandas de la globalización, tal como han sido dictadas desde algún centro metropolitano. En ese sentido, el narrador desafía al Estado autoritario ${ }^{158}$.

El concepto de traducción, en la obra de Piglia, está puesto en relación con la importancia de los textos a los que tuvo acceso Roberto Arlt, en una de las rendijas culturales de la Argentina de los primeros años del siglo XX. La traducción puede observarse como una máquina ideológica. No es gratuito, por eso, el intento de Macedonio de hacer de lo que queda de Elena una máquina de traducir que en realidad se convierte en una máquina de narrar que ha absorbido las tradiciones literarias con unos cuantos temas. Lo que se produce de manera múltiple, con muchas versiones, de manera caótica, se opone a un relato unívoco, homogeneizador, como una puerta a la resistencia social:

Los extraños que circulan por la novela de Piglia giran en torno a la proliferación de textos e identidades puestos en movimiento por el ejercicio de la traducción. Por ende, La ciudad ausente

\footnotetext{
${ }^{158}$ Francine Masiello, op. cit., p. 261.
} 
hace hincapié en la producción de historias menores. La mediación y el proceso de creación son más importantes que los textos que los origina ${ }^{159}$.

Aunque el Estado tenga toda la información necesaria, tomada de sus redes de espionaje electrónico, le resulta imposible alcanzar, realmente, el control total de sus ciudadanos. Una clave de lo anterior son las explicaciones de Fuyita a Junior:

El poder político es siempre criminal -dijo Fuyita-. El presidente es un loco, sus ministros son todos psicópatas. El Estado argentino es telépata, sus servicios de inteligencia captan la mente ajena. Se infiltran en el pensamiento de las bases. Pero la facultad telepática tiene un inconveniente grave. No puede seleccionar, recibe cualquier información, es demasiado sensible a los pensamientos marginales de las personas, lo que los viejos psicólogos llamaban el inconsciente. Ante el exceso de datos, amplían el radio de represión (p. 63).

La incipiente internet de los años noventa no alcanzó a ser representada en La ciudad ausente, pero lo que se describe en sus páginas bien puede aplicarse a la red virtual. El espionaje policial comienza desde esa zona heteróclita ${ }^{160}$ : que no ofrece criterios ni jerarquías y que se presta, en cierto sentido, a la frivolización de la vida humana. Sin embargo, rápidamente, Internet se convirtió en un espacio de denuncia social y política donde la gente terminará por apropiarse del medio, una vez que se hayan inventado nuevos modos de comunicación: "Pronto, con el avance de las nuevas tecnologías, los blogs y los viejísimos emails y los mensajes de texto, serán exhibidos en los museos. ¿Qué lógica es

\footnotetext{
${ }^{159}$ Ibid., p. 264.

160 [El detective] "Ralph nos está esperando al salir del ascensor. Debe tener treinta años, anteojos oscuros, cara de zorro. Vive en un ambiente de techos altos, casi vacío, con ventanales sobre la ciudad. Tiene cuatro computadoras puestas en círculo sobre un amplio escritorio, siempre encendidas, con archivos abiertos y varios sites activados. Ya no hace falta salir a la calle, dice. Lo que se busca, está ahi', Ricardo Piglia, "Notas en un diario. Un detective privado", Babelia, núm. 999, sup. cult. de El país (Madrid), 15 de enero de 2011, http://www.elpais.com/articulo/portada/detective/privado/elpepuculbab/20110115elpbabpor_65/Tes (página consultada el 19 de febrero de 2011).
} 
ésta? Sólo se vuelve artístico -y se politiza- lo que caduca y está atrasado"161. El control de los medios es la base para una resistencia ante el poder político, siempre criminal, de acuerdo con una vieja idea anarquista [Né Dio né padrone].

\section{3 "La nena": relato especular de La ciudad ausente}

\subsubsection{Una muñeca rusa}

Toda la obra narrativa de Ricardo Piglia (sus novelas, sus cuentos, sus relatos críticos y autobiográficos y sus nouvelles, que se desdoblan y ofrecen una visión dual de la realidad negada o anulada, pues se confunde con la irrealidad y lo fantástico) se abre de un modo multifacético en diversos y numerosos relatos y microhistorias que refuerzan la trama principal porque, en muchas ocasiones, esos relatos periféricos que incluso a veces son interrumpidos o quedan sin un final a la manera de un cuento clásico, están sugiriendo implícitamente su conexión con los relatos centrales, lo que les otorga un valor metalingüístico y metaficcional, ya que pueden explicar las historias más extensas que las contienen $^{162}$. Inclusive, la circulación de los personajes de un texto a otro -el caso más notorio es Renzi- sugiere que esa conexión intratextual, tan cercana a la poética de Juan José Saer, puede resolver problemas temáticos y formales: en el caso de la escritura de Piglia, todos los relatos han salido de la máquina de narrar.

Algo semejante ocurre con "La nena", relato que aparece como una de las historias más emblemáticas de La ciudad ausente. Es un relato fantástico que, dentro de la historia

\footnotetext{
${ }^{161}$ Ricardo Piglia, "Notas en un diario. El perro ciego”, Babelia, núm. 1003, sup. cult. de El país (Madrid), 12 de febrero de 2011, p. 23.

${ }^{162}$ Un ejemplo de lo anterior es el texto "Pequeñas historias", incluido en los Cuentos morales. En la advertencia que abre esta antología, se menciona que este texto, junto con "El fluir de la vida", fue publicado en Prisión perpetua (Ricardo Piglia, Cuentos morales. Antología personal (1961-1990), Planeta, Buenos Aires, 1997, p. 7). El escritor argentino ha sacado estas micronarraciones de su con-texto (la nouvelle mencionada) y las ha ubicado en otro desde donde pueden leerse de manera diferente.
} 
central, contiene a su vez otro relato, con algunas variantes, de un tema de la literatura fantástica. De la mayoría de los metarrelatos que llevan título, que salen de la máquina Elena y que Junior lee, escucha u observa en las representaciones del Museo donde aquella se encuentra, "La nena" destaca por no pertenecer al género "realista"; otros textos, que han salido de la máquina de narrar, se distinguen por su temática social, de denuncia: “El gaucho invisible", que en cierto modo vuelve a clausurar el género de la gauchesca y reduce la idealización urbana del gaucho ${ }^{163}$; "La grabación", un relato en código realista sobre las víctimas de la última dictadura argentina, desaparecidas en el campo; "Los nudos blancos", un texto más relacionado con la "ficción paranoica" de la que ha hablado Piglia en varias ocasiones ${ }^{164}$, ya que Elena y el Tano son perseguidos y encerrados en la clínica del doctor Arana; aparte de estos textos, hay otros, colindantes con el género fantástico, como "La isla", un relato de filiación utópica, "Una mujer", breve narración que tiene un final sorpresivo aunque no fantástico, y "Primer amor", texto fantástico como "La nena", si bien de estructura simple y de muy breve extensión.

"La nena" es un metarrelato que ofrece muchas pistas para los lectores implícitos y para Junior, el periodista-detective que explora la ciudad y sus textos como un mapa para llegar a Russo, el inventor. "La nena" se encuentra en el Museo que aloja a la máquina de

${ }^{163}$ Cfr. Ana María Barrenechea, "Inversión del tópico del beatus ille en La ciudad ausente”, op. cit., y Magalí Sequera, "El relato-río: la gauchesca en La ciudad ausente", en Jorge Carrión, El lugar de Piglia, op. cit., pp. 65-82.

${ }^{164}$ En Blanco nocturno, Ricardo Piglia muestra que su novela no puede ser insertada de modo arbitrario y a la manera tradicional en el género policial porque no hay culpable o resolución total del problema, porque la novela giró hacia los problemas de la moral y la injusticia social -lo que obviamente la ubicaría más cerca del género negro que del género clásico inglés, tan caro a Borges y Bioy- y porque Croce, el detective que ha fracasado porque no logra encerrar al verdadero asesino, le dice a Renzi, quien ha ido al pueblo a cubrir la nota del crimen: "No es cierto que se pueda restablecer el orden, no es cierto que el crimen siempre se resuelve... No hay ninguna lógica [...] Las novelas policiales resuelven con elegancia o con brutalidad los crímenes para que los lectores se queden tranquilos" (Blanco nocturno, Anagrama / Colofón, BarcelonaMéxico, 2010 [Narrativas hispánicas, 476 p. 283]). Poco después, Renzi, el alter ego de Piglia, piensa: "Habría que inventar un nuevo género policial, la ficción paranoica. Todos son sospechosos, todos se sienten perseguidos. El criminal ya no es un individuo aislado, sino una gavilla que tiene el poder absoluto" (ibid., pp. 283-284). 
narrar. Junior recorre las salas, observa las reproducciones-escenas de la narradora (una suerte de Scheherezade) y lee el texto ${ }^{165}$, que en realidad también funciona para explicar los procedimientos narrativos y estéticos de la máquina que narra la historia. Este metarrelato, por lo tanto, habla ocultamente de sí mismo pero, también, de la máquina Elena.

Abierto al infinito, el relato de "La nena" es una variación de la máquina de Elena, creada por Macedonio Fernández para que fuera "la Eterna, el río del relato, la voz interminable que mantenía vivo el recuerdo" (p. 46). Todos los textos a los que llega Junior y que han salido de la máquina, como "La grabación”, "Los nudos blancos" o "La isla", sirven para seguir las pistas de uno de sus creadores con la intención de conocer los motivos por los que el Estado quiere desactivarla, pero también funcionan, entre líneas, para comprender la fuerza de la creación literaria como espacio de resistencia social.

De acuerdo con lo anterior, la filiación metaficcional y autorreferencial de "La nena" puede leerse desde una perspectiva política, donde el trasfondo está relacionado con la crítica a los regímenes dictatoriales, como el de la Junta militar que gobernó Argentina entre 1976 y $1983^{166}$. Este signo dual, donde lo metadiegético se une con la denuncia política y social, se sugiere mediante los procedimientos de lo fantástico. Cuando visita el Museo donde el gobierno ha recluido la máquina como una forma habitual de la censura,

\footnotetext{
${ }^{165}$ En la advertencia mencionada de los Cuentos morales, también puede leerse que "La nena", junto con otros metatextos, "son relatos de la máquina en La ciudad ausente" (op. cit., p. 7). Esta aclaración es, sin duda, una invitación para leer esos textos como parte del proyecto narrativo que es la máquina de narrar: de esta máquina y de La ciudad ausente salen todos los relatos de Piglia, incluyendo las novelas.

${ }^{166}$ Como se ha documentado desde la primera edición de La ciudad ausente por parte de la crítica literaria, la novela cuestiona la posición carente de justicia de los primeros gobernantes argentinos posteriores a la dictadura. La política del "perdón" a los militares y la ley del Punto Final de Raúl Alfonsín y sus sucesores fueron inaceptables para los sobrevivientes de las desapariciones y para los familiares de los muertos. En 1992, cuando la segunda novela de Piglia se publica en Argentina, una de las polémicas era decidirse a perdonar y olvidar o a hacer justicia (Cfr. Luis Alberto Romero, "El impulso y su freno. 1983-1989", op. cit., pp. 250-251).
} 
Junior observa y lee distintos relatos de la literatura argentina -y de la literatura mundialque se relacionan con narraciones conocidas e inéditas de la máquina:

En una sala, Junior vio el vagón donde se había matado Erdosain. Estaba pintado de verde oscuro, en los asientos de cuerina se veían las manchas de sangre, tenía las ventanillas abiertas. En la otra sala vio la foto de un viejo coche del Ferrocarril Central Argentino. Ahí había viajado la mujer que huyó a la madrugada. Junior la imaginó dormitando en el asiento, el tren cruzando la oscuridad del campo con todas las ventanillas encendidas. Ésa era una de las primeras historias (p. 47).

La relación establecida entre la literatura de Roberto Arlt con un relato de la máquina (un relato de Piglia, por lo tanto) se encuentra cruzada por lo fantástico: después de leer el relato de la mujer que abandona a su marido, va al casino, gana y sube a su habitación del hotel para suicidarse ${ }^{167}$, como si se tratara de un nuevo Aleph en el Museo, Junior ve la imagen en el hotel en el que, minutos antes, se había encontrado al ir tras la pista de Fuyita, el guardia del Museo: "En una sala lateral estaba la pieza del Majestic y el ropero donde la mujer había buscado el frasco de perfume" (p. 49). Todo lo abarca el ojo de la máquina de narrar, incluyendo lo que pasa en ese mismo instante.

Además de que la relación del final de Los lanzallamas con "Una mujer" (las dos historias terminan con el suicidio del protagonista) establece otro momento en la tradición

${ }^{167}$ Este relato de la novela, titulado simplemente "Una mujer", es en realidad el argumento que Piglia recupera para ilustrar sus "Tesis sobre el cuento": "En uno de sus cuadernos de notas Chéjov registra esta anécdota: Un hombre, en Montecarlo, va al Casino, gana un millón, vuelve a su casa, se suicida. La forma clásica del cuento está condensada en el núcleo de ese relato futuro y no escrito" (Formas breves, op. cit., p. 105). Piglia ha reescrito, al parecer, la anécdota del escritor ruso. Además, cambia al hombre por una mujer, quizá en un guiño al lector de La ciudad ausente cuando se lee en esta novela que "Macedonio siempre estaba recopilando historias ajenas. Desde la época en que era fiscal en Misiones había llevado un registro de relatos y de cuentos. Una historia tiene un corazón simple, igual que una mujer. O que un hombre. Pero prefiero decir igual que una mujer, decía Macedonio, porque pienso en Scheherezade. Recién mucho tiempo después, pensó Junior, entendieron lo que había querido decir. En esos años había perdido a su mujer, Elena Obieta, y todo lo que Macedonio hizo desde entonces ( $\mathrm{y}$ ante todo la máquina) estuvo destinado a hacerla presente" ( $\mathrm{p}$. 46). Como si Elena cambiara el sexo del protagonista para identificarse con éste por su soledad y su tristeza. Este cambio de mujer a hombre ofrece, también, una idea de la literatura circular y, por lo tanto, infinita, si nos remitimos a las "Tesis sobre el cuento", donde el sujeto suicida es hombre. La atribución del argumento a Chéjov conecta a Piglia, además, con la literatura rusa leída y admirada por Roberto Arlt. 
literaria que va de Arlt a Piglia, la presencia de lo fantástico en estas escenas es el preámbulo para otras más donde, nuevamente, lo metaficcional es un procedimiento de lo fantástico y cumple una función social. Tal es el caso de "La nena", que posee la estructura metadiegética de una caja china o una muñeca rusa (la protagonista es una especie de autómata): las múltiples referencias explícitas e implícitas al género fantástico, en un plano superficial y en un plano más profundo, pueden ser interpretadas en relación a la totalidad de la novela como una obra fantástica.

En este sentido, la estructura metadiegética de "La nena" se emparenta, de acuerdo con la tradición fantástica rioplatense, con los procedimientos narrativos de muchos de los cuentos fantásticos de Borges. En Los juegos fantásticos, Flora Botton afirma que la metaficción, en los textos narrativos del autor de El Aleph, es recurrente:

\footnotetext{
hablando con Richard Burgin, [Borges] ha dicho que muchos de sus cuentos son como esas muñecas rusas que se abren para revelar en su interior la presencia de otra muñeca, dentro de la cual hay otra, y otra más... Esta multiplicación de los niveles de lo fantástico es a veces la estructura básica de algunos cuentos: dentro de un cuento que puede ser o no fantástico en sí se relata el argumento de otro que, si se escribiera, definitivamente sería un cuento fantástico ${ }^{168}$.
}

"La nena" posee una estructura metadiegética que sugiere la presencia de lo fantástico, no solo por los motivos tradicionales que toma del género, sino por el desenlace de la historia principal: es el relato de una niña que pierde la facultad de comunicarse, se ha aislado del mundo, queda afásica. En un sentido inverso al de los hijos idiotas y de la hija sana del matrimonio Mazzini en "La gallina degollada" de Horacio Quiroga, Laura "había nacido sana y recién al tiempo empezaron a notar signos extraños” (p. 52). Los hijos mayores son enviados al seminario y los padres se dedican por completo a encontrar la cura para la hija

${ }^{168}$ Flora Botton Burlá, Los juegos fantásticos, UNAM, México, 2003, p. 77. 
menor. Es el padre quien entiende que el doctor Arana no puede ayudar a Laura con su método: este personaje, que aparece en otros momentos de La ciudad ausente, fuera de "La nena", es el emblema de la represión política. Como se dijo antes, Arana remite al Pozo Arana, nombre de uno de los campos de concentración en la época de la dictadura militar $\operatorname{argentina}^{169}$. El método que lleva a cabo con Laura es similar al de Elena, si bien la finalidad es distinta. En el caso de la nena, su terapia consiste en darle una "cura eléctrica" (p. 54), o sea, una serie de electrochoques, como los proporcionados a los activistas opositores. Viendo que no hay resultados con este método, el padre de Laura prescinde de Arana y emplea un método basado en la repetición de estructuras sintácticas musicales y literarias. Con una serie de melodías clásicas y con las variantes del motivo del anillo y la estatua que cobra vida, logra llevar a su hija a la realidad exterior, sacándola de la realidad interior y la incomunicación en que habitaba ${ }^{170}$.

A pesar de su brevedad, "La nena" es un relato con múltiples referencias intertextuales que se combinan con una serie de enunciados que postulan, implícitamente, la relación metaficcional de Laura con Elena: "La preocupaban continuamente las maquinarias, sobre todo las bombitas eléctricas" (p. 53). La narradora, la máquina Elena, habla de sí misma

${ }^{169}$ Cfr. los juicios en la era de los Kirchner, mediante la anulación a las leyes de Obediencia Debida y Punto Final, así como el Pozo Arana, en "Comienzan en Argentina juicios contra represores de la pasada dictadura", nota de Stella Calloni, La jornada, 10 de julio de 2007, http://www.jornada.unam.mx/2007/07/11/index.php?section=mundo\&article=033n1mun, página consultada el 23 de febrero de 2011.

${ }^{170}$ En su ensayo sobre la gauchesca en la narrativa de Piglia, Magalí Sequera interpreta la relación músicaliteratura a propósito del concepto de "relato-río", tomado de La ciudad ausente, que sirve para hacer una metáfora de la creación literaria como espacio de resistencia cultural y social: "De la comparación incesante entre narración, agua y música nace un aspecto purificador y eterno de la palabra" (op. cit., p. 78). Sequera menciona la relación creativa entre Piglia y el músico Gerardo Gandini para hacer la versión operística de $L a$ ciudad ausente; recuerda que la máquina surge a partir del intento de sustituir a los narradores orales que se iban muriendo con Elena (aunque aquí Sequera no menciona "El narrador" de Walter Benjamin, texto fundamental para comprender la novela de Piglia y otros textos más, como "Mata-Hari 55") para terminar con la imagen (visual, porque la ha captado una cámara, cuya proyección Junior puede observar) de Macedonio Fernández como máximo escritor de la resistencia ante el fascismo: "Russo nos pinta una imagen de Macedonio guitarreando en su cuarto de hotel" (Ibid., p. 76), lo que permite, nuevamente, establecer la relación entre literatura y música como sitios de resistencia frente a procesos salvajes, como el del doctor Arana, dentro y fuera del relato de "La nena". 
cuando cuenta lo que ocurre con Laura. Los relatos que narra el padre son también una variante moderna del tema de la estatua que cobra vida y del anillo como leit motiv del argumento, repetido innumerables veces en la tradición occidental:

[...] eligió contarle siempre la misma historia y variar las versiones. De ese modo, el argumento era un modelo único del mundo y las frases se convertían en modulaciones de una experiencia posible. El relato era sencillo. En su Chronicle of the Kings of England (siglo XII), William de Malmesbury refiere la historia de un joven y potentado noble romano que acaba de casarse. Tras los festejos de la celebración, el joven y sus amigos salen a jugar a las bochas en el jardín. En el transcurso del juego, el joven pone su anillo de casado, porque teme perderlo, en el dedo apenas abierto de una estatua de bronce que está junto al cerco del fondo. Al volver a buscarlo, se encuentra con que el dedo de la estatua está cerrado y que no puede sacar el anillo. Sin decirle nada a nadie, vuelve al anochecer con antorchas y criados y descubre que la estatua ha desaparecido. Le esconde la verdad a la recién casada y, al meterse a la cama esa noche, advierte que algo se interpone entre los dos, algo denso y nebuloso que les impide abrazarse. Paralizado de terror, oye una voz que susurra en su oído:

-Abrázame, hoy te uniste conmigo en matrimonio. Soy Venus y me has entregado el anillo del amor (p. 56).

Esta versión elegida corresponde a un eslabón de una larga cadena en la historia de la literatura occidental. Desde el mito de Pigmalión, narrado por Ovidio, este relato ha perdurado hasta nuestros días, convirtiéndose en un motivo central, retomado por autores anónimos y algunos famosos, como Prosper Mérimeé y Henry James ${ }^{171}$. Otra fuente

171 En su Diccionario de argumentos literarios, Elizabeth Frenzel menciona a Ovidio como la fuente principal, después pasa por la tradición medieval cristiana y vuelve a encontrar el motivo en la época del Romanticismo (trad. de Carmen Schad de Caneda, Gredos, Madrid, 1976, pp. 387-389); en la tradición romántica, así como en el modernismo y la época contemporánea, además de Mérimeé (cuya versión es una de las más cercanas a las que se narran en "La nena"), puede mencionarse a Joseph Baron Von Eichendorff (La estatua de mármol), Gustavo Adolfo Bécquer ("El beso"), Rubén Darío ("La muerte de la emperatriz de la China"), Gustav Meyrink (El Golem), Juan José Arreola ("Anuncio", "Parábola del trueque” y "Tres días y un cenicero") y Elena Garro, cuyo cuento "El anillo" retoma, desde una variante folklórica, el motivo de esta historia fantástica en un contexto rural (La semana de colores, Porrúa, México, 2006). Por su parte, en su edición crítica a las Metamorfosis, Consuelo Álvarez y Rosa María Iglesias afirman que las fuentes literarias del tema de Pigmalión, en Ovidio, se remontan a Filostéfano. También mencionan que Ovidio introduce un cambio novedoso: no es Afrodita o Venus la que cobra vida, sino la figura de una simple mujer, a la que la diosa del amor le concede la vida carnal (Ovidio, Metamorfosis, trad. y ed. de Consuelo Álvarez y Rosa María Iglesias, Cátedra, Madrid, 2007 (Letras universales, 228), pp. 565-566). 
mencionada en el relato de Piglia es la leyenda recogida en la Kaiserchronik ${ }^{172}$, también del siglo XII. La variante contiene ya no a Venus, sino a la Virgen María, que se opone a la relación entre otro joven y su esposa después de que aquel le dio el anillo del amor. La narradora Elena también menciona la versión de Henry James en su cuento "La vuelta de los Valerii", “el último de la serie" (p. 58). Ahora no se trata de Venus ni de la Virgen sino de Juno, quien no consigue la separación de la eterna pareja porque la esposa entierra su estatua en el jardín, anulando el proceso ${ }^{173}$ (p. 58).

Con la técnica de la repetición del motivo del anillo y la estatua, al cabo de varios años, el padre de Laura consiguió crear en la mente de su hija una estructura sintáctica a base de repeticiones y variantes para volver a hablar: “Al año la nena ya sonríe, porque sabe cómo sigue la historia y a veces se mira la mano y mueve los dedos, como si ella fuera la estatua" (p. 56; cursivas mías).

Sin embargo, lo fantástico del relato contado por la máquina Elena no es el argumento repetido del anillo y la estatua que cobra vida, sino, principalmente, que una tarde la niña detiene el relato del padre para continuarlo y terminarlo por sí misma:

\begin{abstract}
Mira el jardín y, con un murmullo suave, da por primera vez su versión de los hechos. "Mouvo miró la noche. Donde había estado su cara apareció otra, la de Kenia. De nuevo la extraña risa. De pronto Mouvo estuvo en un costado de la casa y Kenia en el jardín y los círculos sensorios del anillo eran muy tristes", dijo. A partir de ahí, con el repertorio de palabras que había aprendido y con la estructura circular de la historia, fue construyendo un lenguaje, una serie ininterrumpida de frases que le permitieron comunicarse con su padre [...] Llegó a ser capaz de repetir palabra por palabra la versión de Henry James, quizá porque ese relato, The Last of the Valerii, era el último de la serie (pp. 57-58).
\end{abstract}

\footnotetext{
${ }^{172}$ La doctora Laurette Godinas destaca que este vocablo germánico revela la recurrencia de Piglia por los términos anglosajones, dentro del diálogo permanente que establece con la literatura en lengua inglesa.

${ }^{173}$ En este caso, la reseña pigliana coincide en su totalidad con el cuento del escritor estadounidense. Cfr. Henry James, El último de los Valerios y otros cuentos, trad. de Fernando Jadraque, Valdemar, Madrid, 1997, pp. 13-57.
} 
La estructura de "La nena", dentro del mar de historias infinitas que es La ciudad ausente, se abre dentro de sí misma, es una vorágine que se autorrefleja y que en cada nueva variante hay una espiral narrativa. Lo fantástico consiste en que, a fuerza de escuchar una y otra vez las variantes del mismo tema, Laura pueda recitar el texto de James y el de otro autor, cuya historia, al parecer por las referencias, tiene lugar en África ${ }^{174}$, y seguramente es un fragmento de un relato apócrifo, escrito por Piglia. Como una variante de Pierre Menard, Laura cuenta de modo exacto la versión del escritor estadounidense, la última, The Last of the Valerii, según la máquina de narrar. Como en las cartas que en Respiración artificial el estudiante envía de Estados Unidos a Argentina en tiempos de la dictadura, donde lo que supuestamente ha leído (Mr. Sammler's Planet, "Movie" y An Accidental Man) es lo que ocurre inmediatamente en su realidad, Elena, desde el relato enmarcado en la trama policial que pone al periodista Junior como detective, hace que Laura narre dos relatos con toda naturalidad, pero lo hace rompiendo las fronteras de la "realidad" (enmarcada sucesivamente por varios niveles narrativos) y la ficción. Laura logra salir de la forma circular del relato, que por supuesto encuentra su imagen en la figura del anillo, al unir y coordinar las palabras repetidas durante varios años por su padre (como una imagen de la tradición literaria) para elaborar las propias, aunque sus relatos sean otras obras -idénticas, como el Quijote de Pierre Menard- que permiten una lectura de lo fantástico. Se puede escapar de la realidad represiva, representada por el doctor Arana en este relato, mediante el

\footnotetext{
${ }^{174}$ Una vez fuera de la estructura metadiegética de "La nena", Junior observa una edición de la Anatomía de la melancolía de Robert Burton y "el original de los mitos iniciales" (p. 59), que irónicamente remite a la medieval Gesta Romanorum y que tiene en Virgilio a su protagonista: el lector parece perdido en el vértigo de variantes, fechas, épocas, lugares, citas, alusiones, nombres. Lo que estaba dentro de "La nena" ha salido a la realidad, como el cono fantástico de "Tlön", que ha llegado a la realidad de Buenos Aires. Además, como ocurre en las referencias bibliográficas de las cartas que el estudiante de Estados Unidos envía a Argentina, algunas son falsas. En el caso de las fuentes que el padre emplea para su hija, la Kaiserchronik es falsa. Berg afirma que la Chronicle ok Kings of England es apócrifa. (Edgardo H. Berg, op. cit., p. 89). La combinación de relatos auténticos con relatos imaginarios, que no existen, aparece también en estos fragmentos.
} 
poder de la ficción, último bastión de la resistencia social, como ocurre en el relato de "La isla" utópica, también narrado por Elena, al final de La ciudad ausente.

El padre ha regresado a su hija a la vida (aunque siga teniendo "la fijeza de los ángeles” (p. 58) y sus movimientos sean los de un autómata), así como la máquina Elena ha vuelto a ser Elena a través de la invención de la máquina de narrar: la narradora-máquinaElena, por lo tanto, habla de sí misma cuando relata "La nena".

\subsubsection{Entre el género fantástico, el psicoanálisis y la tradición literaria}

En "La nena", La metaficción es uno de los procedimientos narrativos que sugiere, entre líneas, que este texto puede leerse como fantástico. Junior lee y observa escenas tomadas de este relato y de la tradición literaria occidental que desarrolla los motivos del anillo y de la estatua que cobra vida. Pero el recurso metaficcional no se reduce a un solo nivel narrativo, donde la nena, parecida a un autómata o una máquina, remite al lector, nuevamente, a la figura de la máquina Elena, encerrada en el Museo: la historia de "La nena", a su vez, encierra una serie de relatos, seleccionados por el padre, para relacionar la inmovilidad y la afasia de la hija con las estatuas. Una mise en abyme dentro de otra mise en abyme que sugiere la idea de lo infinito en la imagen circular del anillo. La máquina y la nena, la nena y las estatuas.

Por eso, la selección del motivo del anillo y de la estatua, por parte de Piglia, funciona como una reflexión metadiegética y metalingüística, donde el relato del tercer nivel (el de las estatuas y los anillos en sus múltiples variaciones) puede interpretarse dentro del segundo nivel (el de Laura) o el primero (el de Elena, el "tema central" o, por lo menos, el "tema" de donde salen todos los "temas" y narraciones). La mise en abyme vertiginosa que propone Piglia establece, además, una polémica de la literatura fantástica actual, ya que la 
ambigüedad de "La nena", así como su temática, sus recursos y sus referencias, permiten una lectura a caballo entre lo fantástico y la interpretación psicoanalítica, si bien el desenlace y la temática orienten nuestra lectura en el plano del género fantástico.

En más de cuatro ocasiones, la narradora Elena menciona que Laura emite cloqueos, propios de su incipiente condición de autómata: "Sólo emitía un pequeño cloqueo y abría y cerraba los ojos" (p. 53); “sus ojos parecían de vidrio y cloqueaba antes de cantar” (p. 55); “a la noche se arrastró hacia la pieza y se acurrucó en la oscuridad con su cloqueo de siempre” (p. 57); "La nena que cloqueaba era la anti-Scheherezade que en la noche recibía, de su padre, el relato del anillo contado una y mil veces" (p. 57); "Estaba ahí, canturreando y cloqueando, una máquina triste, musical” (p. 58). Esta característica, así como su fijeza de ángel, le proporciona a Laura una imagen de autómata, tema que aparece en otras partes de la novela, fuera de este relato, como en el capítulo de los "Pájaros mecánicos" o en la creación de autómatas por parte de Mology-Nagy, Richter o Russo, científicos y creadores de autómatas.

Para Roger Caillois, uno de los temas del género fantástico tiene relación con

la estatua, el maniquí, la armadura, que súbitamente se animan y adquieren una temible independencia. Los nombres de Merimeé y Achim von Arnim se vinculan en especial con este tipo de historias; el primero por la estatua de la Venus de Ille y el segundo por el Golem de Isabel de Egipto y el maniquí de Marie de Melück-Blainville ${ }^{175}$.

En este contexto, propio de la literatura fantástica, Piglia retoma el viejo tema de los autómatas en el personaje de Laura, estableciendo una relación intertextual implícita, que el lector debe descifrar, con dos cuentos de Hoffmann: "El hombre de la arena",

\footnotetext{
${ }^{175}$ Roger Caillois, "Prefacio" a Antología del cuento fantástico, Sudamericana, Buenos Aires, 1970, p. 16 (cursivas del autor).
} 
principalmente, y "Los autómatas". En ambos cuentos, lo fantástico se centra en las figuras mecánicas de Golems controlados por científicos oscuros o siniestros ${ }^{176}$. En el cuento de Piglia, ocurre una inversión: en lugar de ser golems que tienen apariencia de seres humanos, como ocurre en "Los autómatas", la enfermedad de Laura le otorga una apariencia de estatua, de autómata, de Golem, por lo tanto. Esta tendencia acerca a Laura al protagonista de "El hombre de la arena", Nataniel, quien debido a su desafortunado encuentro con Coppelius, el hombre de la arena, en el que muere su padre, tiene un comportamiento de autómata cuando le viene una crisis psíquica; se comporta como la muñeca Olimpia, creada por el profesor Spalanzani, quien la ha hecho pasar como su hija; el único que cree que Olimpia es humana es Nataniel. Cuando aparece Coppelius nuevamente, ahora con el nombre falso de Coppola, para llevarse los ojos de Olimpia, el protagonista vuelve a tener una crisis, comportándose como la muñeca: entre los gritos incoherentes de autómata de Nataniel, se escucha la frase “¡Muñeca de madera, muñeca de madera, vuélvete!”"177, estableciéndose, de este modo, una relación simbólica entre ambos, cercano al tema del doble. A diferencia de Laura, Nataniel tiene un fin trágico, ya que se suicida en su tercer encuentro con el hombre de la arena ${ }^{178}$.

\footnotetext{
${ }^{176}$ E. T. A. Hoffmann, Cuentos, 1, trad. de Carmen Bravo-Villasante, Alianza Editorial, Madrid, 2002. ${ }^{177}$ Ibid., p. 89.

${ }^{178}$ No menos siniestro es el final de "Los autómatas": al llegar al desenlace, el lector se da cuenta que el relato que parecía contado por un narrador omnisciente en realidad está narrado por un personaje cuya intervención nunca se había notado, dándole al texto una estructura metadiegética. Además, el personaje decide interrumpir la historia del protagonista Fernando, escamoteando un final esperado por su auditorio y los lectores implícitos. Sin embargo, el lector tiene la sospecha de que la interrupción de la historia sugiere que Fernando, quien iba en busca de su amada (otra autómata que él no reconoce como tal) para rescatarla de su padreinventor, en realidad ha fallecido y otro Fernando, un autómata, es ahora actor y cantante de ópera en los teatros europeos. En "La nena", Laura "cantaba arias de Mozart en alemán” (p. 54), lo que en realidad puede comprenderse como una alusión a los cuentos de autómatas de Hoffmann, ya que este escritor sustituyó su tercer nombre, Wilhelm, por el de Amadeus, en honor al músico (Ibid., p. 7). De este modo, la relación intertextual con los cuentos de Hoffmann sugiere un acercamiento de la narrativa pigliana a la literatura fantástica, particularmente con los autómatas y el tema del doble (William Wilson y Stephen Stevensen tienen sus dobles, lo que les otorga un aire siniestro). En ese giro a lo doble, también se encuentra el guiño de Piglia al lector a propósito de Molly Bloom, que canta arias en italiano (Nicolás Bratosevich, op. cit., p. 23), lo que
} 
Una característica de este tema, descrito por Caillois, es que lo inanimado cobre vida, pero también que lo que tiene vida asuma una conducta lenta, silenciosa, de autómata. En esta tradición de lo fantástico, se encuentra el cuento de Piglia, que no niega, aunque sea implícitamente, esa línea temática que incluye "Las Hortensias" de Felisberto Hernández, "La muñeca reina" de Carlos Fuentes, "La muñeca menor" de Rosario Ferré y, por supuesto, en la tradición cinematográfica, El gabinete del doctor Caligari de Robert Wiene, Metrópolis de Fritz Lang e, inclusive, Cagliostro de Vicente Huidobro, novela concebida para ser llevada al cine del expresionismo alemán ${ }^{179}$.

Para Flora Botton, que sigue de cerca los estudios de Caillois, Todorov, Louis Vax y Pierre-Georges Castex, el género fantástico busca despertar emociones y sentimientos de miedo y horror en los lectores, sin llegar al frío raciocinio que despeje las dudas ante lo insólito, que ha entrado a lo cotidiano y que por lo tanto produce confusión ${ }^{180}$. Sin embargo, el fundamento teórico de esta crítica se encuentra limitado porque la mayoría de los relatos que Caillois y Todorov analizan en sus estudios corresponden a la literatura fantástica del siglo XIX, principalmente. Caillois integra a Borges en su Antología del cuento fantástico, pero, aunque las últimas ediciones de esta obra datan de 1967 y 1970, no pueden representar las perspectivas actuales del género. En la literatura fantástica del siglo $\mathrm{XX}$, en muchos casos, los escritores ya no intentan "espantar" a los lectores con sus relatos; en el caso de Piglia, el cuento fantástico de "La nena" ofrece procedimientos

permite exhibir el juego intertextual con Hoffmann y, nuevamente, con Joyce, la referencia literaria no argentina de mayor presencia en La ciudad ausente.

${ }^{179}$ Aunque María Negroni no estudia a Piglia en sus ensayos sobre lo fantástico en la narrativa, la poesía y el cine, sí puede establecerse esa relación a partir de la mirada de la ensayista a las muñecas de Hernández, Fuentes (incluyendo, también, Aura) y Ferré (María Negroni, op. cit).

${ }^{180}$ Botton se basa en las ideas de Vax al respecto: "No existe lo fantástico en potencia -dice Vax-, sólo existe lo fantástico en acto. La actividad artística no destila un concepto para extraer de él el horror que oculta, sino que engendra ese horror para estilizar el motivo" (Louis Vax citado por Flora Botton, op. cit., p. 33). Cfr. también Tzvetan Todorov, Introducción a la literatura fantástica, trad. de Silvia Delpy, Ediciones Coyoacán, México, 1999, pp. 127-128. 
contemporáneos, más actuales (como la autorreferencialidad, si bien este procedimiento siempre ha existido, pero sus modos y funciones han cambiado ${ }^{181}$ ), que establecen, de manera implícita, su inserción en una tradición literaria que no deja de ser cuestionada. Por otra parte, como ya se ha visto en el apartado dedicado a la presencia de lo fantástico en Respiración artificial, el género cumple una función social que, en el caso de "La nena" y La ciudad ausente, también queda establecido de manera similar. De ahí que "La nena", a pesar de sus relaciones intertextuales con los hipotextos que contienen el motivo del anillo y de la estatua, y con los textos donde abundan los autómatas, no sea considerado un cuento fantástico tradicional, sino un texto que dialoga con una tradición del género.

No cabe duda que "El hombre de la arena" es el cuento más famoso de Hoffmann debido al célebre estudio que Freud le dedicó ${ }^{182}$. En la oposición que Todorov hace entre el género fantástico y el psicoanálisis, afirmando que este lo ha reemplazado en la literatura del siglo XX, Flora Botton cree que las herramientas del psicoanálisis han ayudado, más bien, a modificar los temas y sus tratamientos por parte de los escritores del siglo XX. Además, las letras hispanoamericanas conocieron con cierto retraso las tesis freudianas, lo que permitió, según Botton, que hubiera una mayor independencia creativa ${ }^{183}$. Borges, por supuesto, desdeña o ignora los estudios psicoanalíticos, y crea una tradición fantástica en la región del Río de la Plata que tiene sus raíces en la literatura anglosajona. Por otra parte, aunque Todorov sostiene que el psicoanálisis sustituyó a la literatura fantástica, las lecturas que en la actualidad se hacen del género no reflejan una tendencia exclusiva o primordial por parte del psicoanálisis; la narrativa fantástica del siglo XIX se transformó en gran

\footnotetext{
181 "Podemos afirmar que una mise en abyme no constituye, por sí sola, prueba de la modernidad de un texto pero puede llegar a serlo, situada en el entorno adecuado. La mise en abyme es un mercernario textual" (Lucien Dällenbach, op. cit, p. 91).

${ }^{182}$ Sigmund Freud, "Lo siniestro", Obras completas, t. III, trad. de Luis López Ballesteros y de Torres, Biblioteca Nueva, Madrid, 1981.

${ }^{183}$ Flora Botton, op. cit., pp. 24-25.
} 
medida en el siglo XX debido al método freudiano, pero mantuvo su independencia. El ejemplo que Todorov pone es La metamorfosis de Kafka, que puede ser leído desde distintas perspectivas, sin que predomine la psicoanalítica. Aunque el texto de Kafka se sale de los procedimientos tradicionales del género (y quizá esto sea otra de sus contribuciones), “sus relatos deben, ante todo, ser leídos en tanto relatos, a nivel literal. El acontecimiento en La metamorfosis es tan real como cualquier otro acontecimiento literario" ${ }^{\text {. }}$. Deslindando La metamorfosis de lo maravilloso, Todorov postula que toda lectura, sin anular la psicoanalítica, es válida, incluyendo la que se relacione con lo fantástico.

Sin embargo, en el caso de Piglia, esa línea fantástica rioplatense, que funda toda una tradición en la que él mismo se inserta, parece una polémica implícita en "La nena", ya que las alusiones a Hoffmann se conectan, de modo indirecto, con "Lo siniestro" de Freud. Hay, por lo tanto, una discusión oculta entre un género independiente (aunque considerado todavía marginal), como el fantástico, con una gran tradición en la zona porteña, y una de las grandes revoluciones científicas del siglo XX, el psicoanálisis.

Aunque no es mi propósito hacer un análisis de "La nena" desde una perspectiva basada en el estudio de "Lo siniestro" de Freud, podría mencionarse que existen ciertas marcas, ciertos símbolos, que muestran la presencia de un diálogo implícito no solo con el texto de Hoffmann, sino también con el del estudioso austriaco. El tema del doble está presente en buena parte de la literatura pigliana ${ }^{185}$; en "La nena", y de acuerdo con "Lo siniestro" de Freud, la niña que tiene apariencia de autómata (a la inversa de Olimpia en "El hombre de la arena", que es una autómata que simula ser humana) sugiere la presencia del

${ }^{184}$ Tzvetan Todorov, op. cit., p. 136.

${ }^{185}$ Además de las nouvelles que se desdoblan en dos partes ("Nombre falso", "Prisión perpetua" y "Encuentro en Saint-Nazaire"), son frecuentes las referencias a los dobles: William Wilson, Stephen Stevensen, el propio Emilio Renzi como alter ego de Piglia y, recientemente, las gemelas Ada y Sofía Belladona en Blanco nocturno. Cfr., también, Jorge Carrión, "Dos por dos: la multiplicación pigliana. Prólogo" a El lugar de Piglia, op. cit., pp. 9-23. 
doble, del otro yo, como también se afirma en El Golem de Gustav Meyrink ${ }^{186}$. Este autómata $^{187}$, para Borges, es "el otro yo del narrador", tema tan caro para este autor argentino, cuyas versiones se encuentran en varios cuentos, como "El otro" y "Veinticinco de agosto, 1983" y, por supuesto, en el poema "El Golem".

El anillo o la alianza matrimonial remite indudablemente a lo fantástico e, incluso, al cuento maravilloso. Sin embargo, cuando la madre de Laura fallece, el padre, una vez que ha instalado una estructura sintáctica en su hija a través de la música, decide reforzar el método de la repetición tomando el motivo del anillo, que en "La nena" posee un grado de significación más complejo que el de la estatua-autómata. El anillo es símbolo de lo circular y, por lo tanto, de lo infinito, de lo inacabable. Por eso también las referencias a Las mil y una noches, cuya estructura narrativa también es metaficcional y tiende a lo infinito. Siendo una anti-Scheherezade, Laura vuelve a la "realidad" del relato mediante la historia del anillo. Por eso, después de re-citar el texto de Mouvo y Kenia en un estilo indeciso, y de narrar al estilo Pierre Menard, palabra por palabra, The Last of the Valerii, "la nena se fue de la historia, como quien cruza una puerta salió del círculo cerrado del relato y le pidió a su padre que comprara un anillo (anello) de oro para ella" (p. 58). El término anello permite la asociación entre anillo y anhelo, lo que puede redundar en la relación establecida entre padre e hija, con la ausencia de la madre muerta.

Uno de los modos en los que puede resolverse este debate sobre la intromisión de los estudios psicoanalíticos en la literatura fantástica, puede ser a partir del estudio del lenguaje literario. En ese sentido, Piglia supera el problema que él mismo genera con las referencias

\footnotetext{
${ }^{186}$ Gustav Meyrink, El Golem, trad., pról. y notas de Hugo Grünbaum, Juan Pablos Editor, México, 1991.

${ }^{187}$ Para Grünbaum, traductor de Meyrink, el vocablo Golem quiere decir autómata (Ibid., p. 7); para Borges, "Ese hijo de una palabra recibió el apodo de Golem, que vale por el polvo" (Jorge Luis Borges, "Gustav Meyrink, El Golem", Biblioteca personal, Alianza Editorial, Madrid, 1999, p. 95.
} 
intertextuales en "La nena": las versiones del tema del anillo y la estatua son relatadas por un narrador omnisciente, cercano al estilo filológico que busca relacionar un texto con sus fuentes. La paráfrasis resulta fundamental, ya que se trata de transcribir de otro modo (pero también de manera semejante) la anécdota principal: en la Kaiserchronik medieval, la Virgen María (no Venus ni Juno), mediante el epíteto "la Madre de Dios", "se interpone castamente entre los cónyuges, suscitando la pasión mística del joven” (p. 57). El estilo imita el discurso religioso medieval, no sin que exista un tono paródico ${ }^{188}$. Cuando se narra la versión laica de la Chronicle of the Kings of England, del siglo XII, el pastiche representa el estilo conciso de un diccionario de argumentos (como el de Elizabeth Frenzel) que también recupera la versión de Mérimeé: "Sin decirle nada a nadie, vuelve al anochecer con antorchas y criados y descubre que la estatua ha desaparecido" (p. 56).

Las citas anteriores pueden servir para ejemplificar cómo la preocupación de Piglia está centrada en el lenguaje, el modo en que se narran, seleccionan y ordenan las palabras para formar oraciones y encontrar un sentido. Hay un orden, entonces, en el caos de las palabras y los enunciados. Joyce encontró su estilo. Parte del estilo de Piglia se basa en la práctica del pastiche, en el ejercicio de imitación del estilo de otros, como en "Luba", bajo el estilo de Arlt. Algo semejante podría decirse que ocurre en su ensayo "Los sujetos trágicos (Literatura y psicoanálisis)", de Formas breves. En ese texto, Piglia recuerda, a través de la lectura de la biografía de Richard Ellmann sobre el autor irlandés, que Joyce visitó a Jung para que atendiera a su hija loca (Lucia Joyce, homónimo de un personaje de La ciudad ausente: una cantante loca, la mujer de Fuyita):

\footnotetext{
${ }^{188}$ Al respecto, Genette afirma: "La parodia [...] se ejerce casi siempre sobre textos breves sacados de su contexto, frases históricas o proverbios" (Palimpsestos, op. cit., p. 29). Para este estudioso francés, toda cita sacada de su contexto es, de antemano, paródica.
} 
Estaban viviendo en Suiza y Jung, que había escrito un texto sobre el Ulises y que por lo tanto sabía muy bien quién era Joyce, tenía ahí su clínica. Joyce fue entonces a verlo para plantearle el dilema de su hija y le dijo a Jung: "Acá le traigo los textos que ella escribe, y lo que ella escribe es lo mismo que escribo yo", porque él estaba escribiendo el Finnegans Wake, que es un texto totalmente psicótico. Si uno lo mira desde esa perspectiva, es totalmente fragmentado, onírico, cruzado por la imposibilidad de construir con el lenguaje otra cosa que no sea la dispersión. Entonces Joyce le dijo a Jung que su hija escribía lo mismo que él, y Jung le contestó: "Pero allí donde usted nada, ella se ahoga"189.

Pareciera que "La nena" resuelve, con la anécdota de la salida de Laura del encierro circular del relato donde vivía y con la locura de la que Lucia Joyce no pudo escapar, el problema de lo fantástico frente a lo psicoanalítico en la literatura del siglo XX (y del $\mathrm{XXI})^{190}$ : el estudio del estilo y el lenguaje poético es un modo de acercarse al texto y resolver la polémica. El lenguaje salva, pero, también, “el lenguaje mata” (p. 21), como decía la frase en la pared del hotel de Lucía Joyce ${ }^{191}$.

\subsection{La ciudad ausente y el cine: notas para un acercamiento interdisciplinar}

\subsubsection{Tradiciones cinematográficas y literarias}

A pesar de su complejidad y de pertenecer, indiscutiblemente, a la literatura de la "alta cultura", la poética de Ricardo Piglia siempre ha estado en diálogo fecundo con los modos populares de representación. No se trata de reducir el nivel intelectual y artístico de sus

\footnotetext{
${ }^{189}$ Ricardo Piglia, Formas breves, op. cit., p. 63.

${ }^{190}$ En relación a lo anterior, Edgardo H. Berg afirma: "Desde otro ángulo, uno podría pensar esta narración como una resolución feliz de la historia desdichada que compartió James Joyce junto a su hija Lucía" (Edgardo H. Berg, op. cit, p. 89).

${ }^{191}$ Para el análisis del lenguaje en la narrativa de Piglia, en relación con los tipos de discurso que emplea ("géneros discursivos", según la terminología de Bajtín), hay que tomar en cuenta lo que dice al respecto Laurette Godinas, por ejemplo, en la siguiente cita: "la constante de su obra, más que temática, es de índole técnica, es decir, relacionada con estrategias de configuración discursiva recurrentes" (Laurette Godinas, op. cit., pp. 177-178). Cfr. también Mijaíl Bajtín, Estética de la creación verbal, trad. de Tatiana Bubnova, Siglo XXI, México, 1992, y, para el empleo de los géneros discursivos en Piglia, Alfonso Macedo Rodríguez, De la crítica a la ficción ..., op. cit., pp. 9-32.
} 
obras; se trata, más bien, de acercar a la gente a la tradición literaria argentina para establecer una serie de discusiones y preguntas sobre la literatura, la creación y los espacios de resistencia cultural y social.

En esta línea, los trabajos que Piglia ha realizado en colaboración con otros artistas son múltiples: más allá de los guiones que ha escrito para diferentes directores, su aporte no intenta lanzar una "moraleja" o "educar" en la ideología de la izquierda, sino producir una reflexión artística y política que es, ante todo, un gesto propio de su poética. Así, la selección de algunos textos representativos de la literatura rioplatense para ser elaborados en el formato de la historieta, precedidos de un ensayo suyo, bajo el tema general de la violencia en el simbólico título de La Argentina en pedazos ${ }^{192}$, busca profundizar en algunos aspectos de su proyecto estético: por un lado, se encuentra la selección de textos de la tradición literaria en su relación con los gobiernos dictatoriales, como "El matadero" de Esteban Echeverría, o de textos puestos en relación con su canon personal, como ocurre con la representación visual de la escena de la muerte de Haffner, el Rufián Melancólico, en Los lanzallamas.

En su relación con los productos clásicos de los medios masivos de comunicación, como el cómic, el filme, y la ópera -aunque esta última se ubica en una forma de expresión menos cercana a la cultura de masas-, la obra de Piglia indaga en los modos de transmisión de un texto literario, sin que forzosamente tenga que ver con el papel impreso o los géneros

\footnotetext{
${ }^{192}$ Ricardo Piglia, La Argentina en pedazos, op. cit. Además de este primer acercamiento al mundo del cómic, se encuentra la adaptación de La ciudad ausente como novela gráfica, con dibujos de Luis Scafati y prólogo de Pablo de Santis (op. cit.). Otra muestra de la relación entre los mass media y las obras de Piglia se encuentra en su trabajo en colaboración con el músico Gerardo Gandini para la versión en ópera de La ciudad ausente.
} 
tradicionales $^{193}$. Como se ve en La ciudad ausente, todos los aparatos útiles para la transmisión de información, la conservación de la memoria y la discusión sobre el futuro de la literatura son usados con fines de resistencia y sobrevivencia: relatos de grabadoras ("La grabación”), relatos fotocopiados (“Los nudos blancos”), reproducciones fotográficas y pictográficas de escenas narradas por la máquina ("La nena”, la visita de Junior al Majestic, “Una mujer”, etc.), pájaros mecánicos, fotografías de la maqueta de la ciudad de Buenos Aires (en el "Prólogo" a El último lector), son algunos ejemplos.

Quizá el aparato más cautivante antes del surgimiento de Internet sea el cinematógrafo, que contribuyó a la democracia de las naciones modernas; es un elemento fundamental de los cambios del registro discursivo. En la época actual, donde la experimentación de géneros literarios es una constante en autores como Piglia ${ }^{194}$, otro cruce que puede encontrarse se produce entre su narrativa y el cine.

Una parte de los textos de Piglia pueden analizarse a la luz de esta relación ${ }^{195}$. Sin embargo, más que un tema que pueda ser reescrito, en el discurso y en la selección de los géneros "marginales" es donde se encuentra la mayor influencia del cine sobre la literatura del autor argentino.

Para Ricardo Piglia, la figura de Jean-Luc Godard resulta fundamental, pues lo considera uno de los grandes narradores, ya que sus procedimientos permiten establecer una relación entre el cine y las letras: "siempre me ha parecido un punto de referencia

\footnotetext{
${ }^{193}$ En su ensayo "La máquina de escribir", Liliana Weinberg observa que las máquinas piglianas, como la máquina de contar, pueden "espiar, desarticular, parodiar, burlar" (Liliana Weinberg, "La máquina de escribir”, en Rose Corral (ed.), op. cit., p. 172).

${ }^{194}$ Al respecto, Vila-Matas ubica a Piglia dentro del destacado grupo de escritores que integran "una tradición culta y cervantina que se dedica, entre otros asuntos, a borrar los límites entre los géneros, lo que está permitiendo ver a los lectores cómo se mezclan, al estilo Sarmiento pero de forma menos rusa, el ensayo, la ficción, la autobiografía, el diario personal y los aforismos" (Enrique Vila-Matas, op. cit., p. 264).

${ }^{195}$ Sin tiempo para profundizar en este aspecto, solo podemos mencionar el caso de "El pianista", cuento que forma parte de la versión más reciente de La invasión (2006).
} 
importante, porque Godard utiliza de una manera muy particular los textos y las citas en los films"196. Piglia hace énfasis en uno de los grandes momentos de Alphaville, la gran película de ciencia ficción del director suizo, al final, cuando la máquina que controla la ciudad está re-citando versos de algunos poemas de Borges, lo que permite suponer un “arte del desvío" según Graciela Speranza, iniciado con Marcel Duchamp, pasando por Borges y Godard y llegando a la literatura de Ricardo Piglia ${ }^{197}$.

Las acusaciones de plagio hacia el cine de Godard pueden indicar hasta qué punto la revolución estética emprendida por Duchamp (siguiendo en esto a Speranza) con su Gioconda con bigote y otras obras posteriores tuvo un alto impacto en otros artistas: "Escribiré viejos versos sobre las formas nuevas"198, dice Godard, lo que supone una apropiación del material que ya es del público para decir de otro modo lo mismo, en cierto sentido.

En su diálogo con el cine, a pesar de que el escritor argentino no reconoce como una influencia decisiva en su poética, sino tangencial ${ }^{199}$, La ciudad ausente se encuentra en la línea de filmes donde un detective sigue una serie de rastros; tal sería su relación con $E l$ ciudadano Kane de Orson Welles, Alphaville de Godard (filme en el cual el detective Lemmy Caution busca al científico Von Braun) y Blade Runner de Ridley Scott, la

\footnotetext{
${ }^{196}$ Infra, p. 182.

${ }^{197}$ Graciela Speranza, op. cit., p. 259. El ingenioso y afortunado acercamiento de Speranza a la obra de Piglia se centra, sobre todo, en la nouvelle "Nombre falso". Por otro lado, en el acto de delación de la amante del Nene Brignone, Giselle, en Plata quemada, puede verse una variante del tema de la traición que se relaciona con $A$ bout de souffle (Sin aliento) de Godard, que a su vez había re-citado escenas similares de las películas estadounidenses.

${ }^{198}$ Ibid, p. 274.

199 En una entrevista sobre el cine, Piglia descarta que su novela pueda simbolizar la técnica del zapping propio de la televisión y el cine y aclara, de paso: "No la pensé ligada al cine. Lo del zapping viene seguramente porque la novela maneja muchas historias simultáneamente, que se van intercalando. Como sabemos, es la historia de una máquina que cuenta historias y en realidad esa máquina es una mujer [...] Pero no he pensado en el cine, en el sentido en que se suele decir que el cine influye sobre la literatura [...] En mi caso, si ha habido alguna influencia del cine, ha sido tangencial" (Emiliano Ovejero, "Piglia y el cine", en Jorge Carrión, op. cit., pp. 234-235).
} 
adaptación de la citada novela ¿Sueñan los androides con ovejas eléctricas? de Philip K. Dick. Las dos últimas películas son consideradas obras representativas dentro del género de la ciencia ficción, que también es considerado marginal en el mundo del cine. La figura de Junior se parece al implacable Lemmy Caution cuando este mata al invasor de su habitación de hotel una vez que ha llegado a Alphaville: cuando llega al hotel Majestic, más que un periodista, parece un detective de las novelas negras:

-Soy Junior -dijo-. Necesito ver a Fuyita.

$-¿ Y$ Y - preguntó el viejo con su sonrisita recelosa.

-¿Sabe si está?

- ¿El señor Fuyita? No sé decirle. Hable con el administrador.

-Lindo gato -dijo Junior, y agarró al gato del lomo con un gesto rápido. Lo apretó contra la madera y el animal gritó aterrorizado $[\ldots]$

-Lo único que tengo en la vida es este pobre animal -rogó el viejo-, no me lo lastime (p. 20).

Por supuesto que también existe una gran relación con Blade Runner, que el propio Piglia ubica en la línea de las obras cinematográficas que se relacionan con La ciudad ausente; como el detective Deckard, que analiza grabaciones en busca de pistas que puedan conducirlo a la cacería de replicants (réplicos), Junior, el periodista-detective, escucha en taxi el relato "La grabación”. Más allá de esta analogía, podemos pensar en la relación manifiesta entre los clones, los dobles de los seres humanos que se niegan a ser desconectados y que por lo tanto se encuentran fuera de la ley, con el tema de la nena autómata de la máquina de narrar. En otro paralelismo, la figura del inventor Russo, el creador de los pájaros mecánicos y la máquina Elena, en La ciudad ausente, se parece a la del inventor J. F. Sebastian, del filme de Scott: su afición al ajedrez es otra semejanza. 


\subsubsection{De mundos paralelos}

Lo que sin duda establece una relación intertextual con el género de la ciencia fícción es el ambiente represivo en todas las historias, desde Metrópolis de Fritz Lang, pasando por Alphaville y Blade Runner, y aterrizando en La ciudad ausente.

Esta genealogía literaria desemboca en la escritura de un guión para la película $L a$ sonámbula, de Fernando Spiner, quien le pidió a Piglia que escribiera un texto con una temática semejante a La ciudad ausente, después de haber leído la novela ${ }^{200}$. El resultado aclara Piglia- no es una adaptación cinematográfica del texto: “es una especie de versión de La ciudad ausente, pero que no tiene nada que ver con mi novela, pero tiene ciertos climas de ella",201.

La sonámbula narra la historia de una mujer, Eva Rey, que tiene sueños donde ella y el resto de los ciudadanos de Buenos Aires viven en un mundo alterno o paralelo. En la línea de algunos personajes femeninos de la narrativa pigliana, no se sabe si es una delatora y una espía, por lo que la ambigüedad está presente en todo el filme. La figura casi arquetípica del inventor, que remite al espectador a los profesores psicóticos de Metrópolis y El gabinete del doctor Caligari -en la línea del expresionismo alemán que pasa, como si fuera cita literaria o alusión, en el profesor Von Braun de Alphaville y en la galería de profesores-inventores excéntricos, como el propio Russo de la novela de Piglia o el Russell del "Prólogo" a El último lector- se encuentra en el doctor Ariel Kluge.

El nombre Eva y el apellido Kluge tienen un alto grado de significación en la poética de Piglia. Eva alude a la novela de Villiers de L'isle Adam, La Eva futura, uno de los hipotextos de La ciudad ausente, tomando en cuenta que el propio autor así lo ha

\footnotetext{
${ }^{200}$ Infra, p. 178.

${ }^{201}$ Ricardo Piglia en entrevista con Emiliano Ovejero, op. cit., p. 252.
} 
señalado $^{202}$; por otro lado, el apellido Kluge, de origen alemán, aparece por primera vez, en la obra narrativa de Piglia, en el contexto del primer capítulo de la primera versión que entregó a la prensa. El rastro de Kluge es una pista importante gracias a que Berg comenta esta primera versión, a propósito del efecto macedoniano en Piglia al anunciar una nueva novela, retardar su publicación, ofrecer fragmentos, volver a prometerla, etcétera. En "Otro relato que comienza", la versión primitiva del texto, "aparecen ligeras variantes en los nombres de algunos de sus personajes -el ingeniero Kluge en vez de Russo o Renzi en lugar de Junior-" "203. Estos cambios, mínimos al comparar texto y pretexto, resultan importantes si tomamos en cuenta que el apellido Kluge es más alemán que el apellido Russo, lo que permite establecer una mayor relación con La sonámbula pero, sobre todo, que el nombre representa la tradición alemana del cine de vanguardia, comenzando con el expresionismo alemán. Otra pista que Piglia deja, como de paso, se encuentra en la entrevista con Ovejero: al pensar en la relación entre literatura y cine, a propósito de las adaptaciones que los directores han intentado llevar a cabo, y que relaciona a Eisenstein con Tretiakov, a Orson Welles con Dos Passos y Faulkner, el escritor argentino establece una conexión entre Bertolt Brecht con Alexander Kluge. Las poéticas de ambos se cruzan en la búsqueda de una mayor participación por parte de los receptores, tomando en cuenta la síntesis vanguardia-revolución. El teatro épico del autor de El círculo de tiza caucasiano es paradigmático en el intento de que el espectador sea capaz de reconocerse en el problema moral, económico y político que se pone en escena.

\footnotetext{
202 Marco Antonio Campos, "Epílogo. Entrevista con Ricardo Piglia”, en Ricardo Piglia, Cuentos con dos rostros, pról. de Juan Villoro, UNAM, México, 1999, p. 175.

${ }^{203}$ Edgardo H. Berg, op. cit., p. 81.
} 
La pista del apellido Kluge, que Piglia había colocado sutilmente en el borrador del capítulo inicial de La ciudad ausente y en el relato alternativo de su narrativa que es $L a$ sonámbula, se aclara de pronto con la sexta entrega de sus "Notas en un diario":

\begin{abstract}
Martes. Pasamos un par de días viendo - con intervalos- las nueve horas del filme de Kluge sobre $E l$ Capital de Marx. En verdad es un ensayo narrativo sobre las fantasmagorías del capital, sobre su capacidad de creación de nuevas realidades. Por un lado retoma la potencia corrosiva del Manifiesto Comunista (la forma del manifiesto como irrupción de una nueva visión crítica). Por otro lado renueva la discusión sobre el concepto de fetichismo de la mercancía y analiza el carácter ilusorio de lo real en la sociedad capitalista. Muy buena utilización de los letreros, las consignas escritas y los carteles como imágenes verbales, en la línea del constructivismo ruso. Una lección de pedagogía política y de arte didáctico donde conviven el montaje y los proyectos de Eisenstein, el capítulo del catecismo del Ulises de Joyce y los poemas de Brecht. Una nueva dramaturgia histórica en la época de la tecnología avanzada ${ }^{204}$,
\end{abstract}

lo que permite volver a cruzar la vanguardia con la revolución. Graciela Speranza recuerda esa frase, aparentemente rara, de Piglia: "Me gusta Godard porque me gusta Brecht" ${ }^{\text {205 }}$. Las máquinas creadas por la ingeniería del capitalismo en la era industrial son pensadas como instrumentos de la resistencia. La máquina Elena está pensada dentro de esta tradición vanguardista y crítica, en la línea de Benjamin, Brecht y Kluge.

La sonámbula (1997) amplía las posibilidades de discurso en la poética de Piglia. La supuesta ambigüedad que puede provocar el cruce de géneros en La ciudad ausente, sobre todo en el caso de la ciencia ficción y el fantástico, queda despejada si se analiza la novela desde la estructura metadiegética. En el caso de La sonámbula, el género, que es

\footnotetext{
${ }^{204}$ Ricardo Piglia, "Notas en un diario. El bar de Scott Fitzgerald", Babelia, sup. cult. de El país (Madrid), 18 de junio 2011, http://www.elpais.com/articulo/portada/bar/Scott/Fitzgerald/elpepuculbab/20110618elpbabpor_58/Tes, página consultada el 27 de julio de 2011. En la anotación de un día previo al de la cita anterior, Piglia afirma que "Kluge trabaja como nadie la diferencia entre el sentido de la experiencia y el vacío impersonal de la información. La literatura como historiografía".

${ }^{205}$ Ricardo Piglia citado por Graciela Speranza, op. cit., p. 275.
} 
predominantemente, propio de la ciencia ficción, también puede admitirse una interpretación desde el fantástico, ya que establece la existencia de un mundo paralelo, a la manera de El hombre en el castillo de Dick y "La trama celeste" de Bioy, el final de la historia y algunos comentarios del autor del guión.

Como en la escena inicial de Metrópolis de Fritz Lang, la ciudad de Buenos Aires aparece como una obra donde la tecnología está puesta al servicio de las vías de comunicación: amplias avenidas colocadas a distintas alturas, edificios muy modernos, de gran altura y un ambiente ligeramente siniestro. Las escenas, en colores oscuros, sugieren la idea de un mundo anómalo; poco a poco, el espectador va comprendiendo que el relato es parte de un sueño colectivo, creado para evadir la realidad. En este aspecto, es donde el filme mantiene una gran cercanía con La ciudad ausente y El hombre en el castillo.

Más allá de un historia que transcurre en el futuro, y de la intriga, creada a partir de una sonámbula que no se sabe si está con la resistencia o con el gobierno que ha impuesto esa realidad y que ha encarcelado a los disidentes o a los que se atreven a cuestionar esa realidad, el procedimiento de lo fantástico se resuelve mediante el sueño. En el documental que analiza y presenta algunos momentos en la realización del filme, Piglia afirma que “para acceder a la verdad paralela el sueño es el camino". Como el personaje de "Las ruinas circulares", de Borges, el conocimiento de vivir en un plano onírico creado por otro produce la negación autómatica y la supresión de esa realidad que se creía verdadera. Cuando Eva resuelve atacar a Kluge, el creador del mundo irreal, todo vuelve a la estabilidad: en el mundo real, Eva y Kluge son esposos: la búsqueda de la mujer perdida, la sonámbula, que por supuesto ofrece ciertos paralelismos con el personaje Elena Fernández, ha llegado a su fin en ese mundo alterado por la ilusión. A diferencia de Macedonio, Kluge 
(o su doble en el mundo verdadero) consigue recuperar a la mujer amada que se había extraviado.

Si aceptamos la tesis de que toda la literatura de Ricardo Piglia (incluso la que él pone en diálogo con sus textos: la tradición literaria que él ha venido comentando desde $L a$ invasión y Nombre falso hasta Blanco nocturno, pasando por los textos de Formas breves) ha salido de la máquina de narrar, en un juego literario que despliega múltiples posibilidades de significados y significaciones, La sonámbula, obra paralela y gemela de La ciudad ausente, también es una narración salida de la máquina, de ahí que siempre existan vasos comunicantes entre los textos piglianos, con variantes de temas y motivos.

\footnotetext{
Yo creo que La sonámbula podría ser un relato de la máquina, podría formar parte de la novela en la medida de que La ciudad ausente es una novela sobre mundos posibles, sobre realidades alternativas, sobre cómo en una ciudad hay muchas ciudades y entonces en un punto uno podría imaginar que $L a$ sonámbula es como un desvío del mundo que está presente en La ciudad ausente ${ }^{206}$.
}

Si es verdad, como afirma Edgardo H. Berg en una de las citas de arriba, que La ciudad ausente se contruye sobre la resistencia al control mental e ideológico del aparato gubernamental y sus instituciones de vigilancia y comunicación, la literatura fantástica y la ciencia ficción funcionan como géneros que, al cuestionar la realidad establecida, impuesta e institucionalizada del Estado, producen una profunda reflexión sobre los modos de la manipulación a nivel masivo. Como el joven criminal de La naranja mecánica de Stanley Kubrik, que es reformado mediante un riesgoso procedimiento llevado a cabo mediante la acumulación de imágenes a una velocidad donde nada se comprende y todo llega al inconsciente, la imposición de una memoria artificial, contra la que lucha Elena en "Los

\footnotetext{
${ }^{206}$ Infra, pp. 177-178.
} 
nudos blancos", es una metáfora de los modos en que los ciudadanos son controlados. La apropiación de los recursos, las máquinas y los medios de acceso a la audiencia podrían permitir la existencia de un mundo diferente al que proponen los gobiernos actuales. Ante la poca posibilidad de que esto ocurra, la literatura se convierte en uno de los escasos espacios de resistencia social y cultural, donde las utopías, malintencionadamente ubicadas dentro de la literatura fantástica en muchas ocasiones, logran cumplirse. 


\title{
III. UNA POÉTICA DE LO FANTÁSTICO: "ENCUENTRO EN SAINT-NAZAIRE" Y LAS MÚLTIPLES VERSIONES DE UN RELATO
}

\author{
Pero si la historia que me contó no es verdadera \\ entonces Stephen Stevensen es un filósofo y un mago, \\ un inventor clandestino de mundos como Fourier o Macedonio Fernández \\ RICARDO PIGLIA, "Encuentro en Saint-Nazaire"
}

La tercera nouvelle de Piglia -antes aparecieron "Nombre falso" (1975) y "Prisión perpetua" (1988) - tiene una curiosa historia editorial: por un lado, su primera edición fue bilingüe, apareció en español y en lengua francesa, de acuerdo con una cronología fijada por el propio escritor argentino ${ }^{207}$ en 1988, con el título de Une rencontre a Saint-Nazaire, en la ciudad homónima, por la Maison de Écrivans Étrangers et des Traducteurs; por otro, las ediciones posteriores, escritas en español, han sido escasas y en una disposición textual que permite varias lecturas en el juego que se establece con los géneros literarios. La primera edición en español se publica en 1995, en Cuentos morales ${ }^{208}$; el texto se lee más dentro de las convenciones de ese género que como una nouvelle, ya que no aparece la segunda parte de la narración. El relato completo vuelve a aparecer, cinco años después, en la primera edición española de Prisión perpetua (Lengua de Trapo), al lado de la nouvelle homónima. En el transcurso de la publicación de la gran mayoría de sus textos a la colección Narrativas hispánicas de Anagrama, Piglia decide integrar la nouvelle que nos

\footnotetext{
${ }^{207}$ Cfr. Jorge Fornet, Ricardo Piglia, op. cit., p. 278, y Jorge Fornet, El escritor y la tradición, op. cit., p. 200.

${ }^{208}$ Ricardo Piglia, Cuentos morales. Antología (1966-1990), introducción de Adriana Rodríguez Pérsico, Espasa Calpe, Buenos Aires, 1995 (Austral). La segunda edición mantiene los mismos textos, a excepción de la introducción de Rodríguez Pérsico: Cuentos morales. Antología personal (1961-1990), op. cit. De paso, hay que insistir que este texto se publicó por primera vez en la edición citada de Cuentos morales en 1995 y no en la primera edición de Prisión perpetua, en 1988, como afirma José Manuel González Álvarez. La confusión de ese autor se debe a que no consultó edición (Buenos Aires, Sudamericana, 1988) aunque la cite, sino la que publicó Lengua de Trapo en España, en 2000. (Cfr. José Manuel González Álvarez, op. cit, p. 14.)
} 
ocupa a la que ha sido la última edición de Prisión perpetua, en 2007. En esta ocasión, solo aparecen las dos novelas cortas, en un claro signo de dualidad que a su vez se desdobla en dos partes: "Prisión perpetua" y "El fluir de la vida", "Encuentro en Saint-Nazaire" y "Diario de un loco"-las anotaciones del personaje Stevensen-, respectivamente.

\subsection{El arte de la difracción}

Difracción. Forma que adquiere la vida al ser narrada en un diario personal STEPHEN STEVENSEN, "Diario de un loco"

Si en "Nombre falso" se narra el hallazgo de un manuscrito de Roberto Arlt ${ }^{209}$ y en "Prisión perpetua" se relatan los orígenes de la vida literaria de Ricardo Piglia (en ambas obras el autor aparece como narrador-personaje, en un gesto doble que logra fundir y confundir las nociones de ficción y realidad), en "Encuentro en Saint-Nazaire" se narran las experiencias del autor-narrador-personaje con Stephen Stevensen a su llegada al puerto francés. Stevensen está experimentando con la realidad y la escritura profética, por lo que el narrador se convierte en su autómata, ya que ejecuta los actos que aquel escribe en su diario. Sabemos que se trata del "personaje" Ricardo Piglia a partir de ciertas referencias autobiográficas, diseminadas a lo largo del texto: "Debo decir por mi parte que he sido escritor" ${ }^{210} ;$ “[...] desde que subí al tren en París y tal vez desde que tomé el avión en Buenos Aires [...]” (p. 83), aunque nunca aparece su nombre. La mayor certeza de que se trata de Piglia la ofrece él mismo, en la "Nota" final del libro, que coincide con algunos

\footnotetext{
${ }^{209}$ Ricardo Piglia, Nombre falso, Anagrama, Barcelona, 2002 (Narrativas hispánicas, 322).

${ }^{210}$ Ricardo Piglia, Prisión perpetua, op. cit., p. 82. A partir de este momento, después de citar este texto sólo pondré entre paréntesis el número de página correspondiente.
} 
datos mencionados anteriormente, como el de su estancia en la Maison durante varias semanas, lo que permite un cruce entre el texto y su paratexto y entre lo ficcional y lo real y pone en crisis, de paso, estos conceptos, ubicándose, con este procedimiento, en la línea fantástica de Macedonio y Borges.

Esta puesta en crisis de los conceptos de realidad y ficción se debe, principalmente, a los procedimientos de un estilo autobiográfico y autorreferencial:

El relato incluye la peripecia autobiográfica vinculada con la Residencia [...] Y sin solución de continuidad interfiere o es interferido por un discurso fantástico-oracular, donde el encuentrodesencuentro Piglia-Stephen Stevensen, el otro 'residente' que hace al caso (y otras menciones latelares de indudable realidad -Soerensen, Giuseppe Conte, Miguel de Francisco) tejen una trama de delirio entre los espacios de la Maison Saint-Nazaire y el Hótel de la République ${ }^{211}$.

A la manera de muchos de los relatos de Borges, en "Encuentro en Saint-Nazaire" hay un narrador-personaje asociado con el autor. "Borges" en "El Aleph" y Piglia en cualesquiera de sus nouvelles permiten un cruce entre lo real y lo imaginario. En esta última narración, si la comparamos con las anteriores novelas breves desdobladas, es donde el escritor de Adrogué tiene un mayor acercamiento a lo fantástico. La "expresión de la irrealidad" que le permite barajar nombres reales con personajes ficcionales, así como comentar textos auténticos y asociarlos con relatos apócrifos u originados a partir de las experiencias con un personaje ficcional como Ratliff, "maestro" del autor ("Luba" y "El fluir de la vida", respectivamente), es un recurso típicamente borgiano. Para Nicolás Bratosevich, esta nouvelle poco estudiada por la crítica puede ser leída como un texto "fantástico-oracular", pero también como "una alegoría (plural) sobre la literatura"212. Sin embargo, además de

\footnotetext{
${ }^{211}$ Nicolás Bratosevich, op. cit., p. 18.

212 Ibid., p. 29.
} 
este hallazgo donde Stevensen sería una alegoría de la escritura del diario (y que nos toca a sus lectores descifrar con mayor profundidad), observo que hay una significativa vuelta de tuerca en el texto de Piglia a sus intentos de comprender qué es la literatura y cómo se desvincula del concepto tradicional de "realidad" a partir del estudio de sus procedimientos narrativos y la función social que cumple la literatura fantástica en su poética. A través del diario de Stevensen, se anticipa el diario de Piglia ${ }^{213}$. Doble movimiento que vuelve a confundir las normas de la realidad con los efectos de lo ficcional: "La desviación de un rayo luminoso -según la definición de "difracción” del $D R A E$ - al rozar el borde de un cuerpo opaco" no solamente permite la unión de la ciencia física con la creación literaria, sino que además sugiere el cruce entre la ilusión óptica y lo extraordinario, entre lo real y lo fantástico: la última entrada del diccionario-diario de Stevensen, "Visión", es casi idéntica a la última parte de la primera entrega de los fragmentos del diario que Piglia publicó recientemente para El país y Clarín. En ambos textos, se narra el encuentro entre el narrador (Stevensen en el primer caso, Piglia en el segundo) y un viejo profesor de física alemán (otra vez el binomio ciencia-literatura) que observa el vuelo extraviado de los patos que van a morir. Si se comparan ambas lecturas, el efecto mantiene una doble intención, creada de manera inversa. En el diario de Stevensen, se afirma que Karl Unger, el profesor exiliado, "ha enseñado física aqui en Princeton” (p. 145, cursivas mías). ¿En qué momento Stevensen se fugó a Estados Unidos? Ortodoxo en su escritura, Ricardo Piglia no comete un error involuntario: se trata de un guiño a los lectores sobre el anuncio de la publicación ya no tan lejana de su diario, en vida, no póstumamente. ("El Diario podía haber sido

\footnotetext{
${ }^{213}$ Cfr. "Encuentro...", op. cit., pp. 145-147, y "Notas en un diario. Un detective privado", op. cit.
} 
escrito por mí” (p. 107), había anticipado irónicamente en la presentación de algunos fragmentos del diario de Stevensen ${ }^{214}$.)

Para Deleuze y Guattari, el Diario de Kafka atraviesa toda su obra literaria: “es el rizoma mismo"215. Paralelamente, puede sostenerse que el diario-por-venir de Piglia y otro enlace fundamental de su escritura, La ciudad ausente, son rizomas que atraviesan toda su producción literaria. Con los fragmentos anteriormente citados del diario de Piglia y del "Diario de un loco", queda anunciado que en ese diario se revelarán, de modo implícito, algunos de los procedimientos literarios que atraviesan su obra y que responden a una poética donde el cruce entre realidad, ficcionalidad y literatura fantástica cada vez es más claro. Así, ahora puede comprenderse mejor la frecuente repetición de frases, ideas y variantes en sus narraciones y sus reflexiones:

Sólo puedo hacer una cosa por vez. Lento. Me muevo poco. Mi vida se ordena en series discontinuas. Hay una persistencia invisible de los hábitos. La serie de los bares, de las lecturas, de la política, del dinero, del amor, de la música. Ciertas imágenes -una luz en la ventana en medio de la noche; la ciudad al amanecer- se repiten a lo largo de los años.

Me gustaría editar este diario en secuencias que sigan las series: todas las veces que me he encontrado con amigos en un bar, todas las veces que he ido a visitar a mi madre. De ese modo se podría alterar la causalidad cronológica. No una situación después de otra, sino una situación igual a otra. Efecto irónico de la repetición.

Estas ideas surgen cuando estoy dando mis últimas clases en Princeton.

${ }^{214}$ González Álvarez identifica otra marca del diario de Piglia en el diario de Stephen: se trata de la entrada "Diario", que es en realidad un fragmento que también aparece, con variantes, en la nouvelle "Prisión perpetua". Cfr. José Manuel González Álvarez, op. cit., p. 149. Por otro lado, agradezco la observación de la doctora Laurette Godinas a propósito de una nueva relación entre Piglia y la filología, disciplina a la que el escritor argentino se ha acercado menos en el discurso crítico que en el literario: "en crítica textual, el término difracción indica el surgimiento de errores múltiples a partir de un lugar poco inteligible (= opaco) en el modelo". De este modo, la difracción no solo se produce por la narración de hechos personales en un diario, también puede identificarse en las múltiples versiones de un relato, cuando el original se ha perdido, como ocurre con los textos que leen los personajes de "La isla" en La ciudad ausente. Para un acercamiento a la filología en su relación con el empleo del lenguaje en la obra de Piglia, cfr. Laurette Godinas, "Entre política y tradición: Ricardo Piglia, la filología y el lenguaje", op. cit.

${ }^{215}$ Gilles Deleuze y Félix Guattari, op. cit., p. 65. Por su parte, José Manuel González ya había recordado la importancia que el Diario de Kafka tiene en el laboratorio de la escritura pigliana (op. cit., p. 146). 
Un seminario sobre Poéticas de la novela. Otra serie posible: todas las veces que he entrado a dar clase en el aula B-6-M de Firestone en estos catorce años y lo que ha sucedido después ${ }^{216}$.

\subsection{Versiones y di-versiones, evolución literaria y sociedad}

Una entrada lateral al análisis de lo fantástico en "Encuentro en Saint-Nazaire" se ubica en los cambios introducidos en las últimas versiones del relato. La mayor transformación del texto se produce a partir de su publicación en la edición de Prisión perpetua de 2000. Como ilustración a dichos cambios, los testimonios de 1995 y de 2007 serán suficientes.

Las modificaciones más significativas tienen relación con los títulos de las obras literarias creadas por Stevensen y con la profesión de su hermana, Maggie Stevensen, quien a veces dice que se llama Erika Turner (p. 99 ${ }^{217}$. En el primer texto, Stephen ha escrito la novela El universo de Valmont; en la edición de 2007, ese texto se titula El cristal de Ur. En el segundo caso, dentro del relato inserto en la antología de 1995, Maggie se dedica a las matemáticas, mientras que en la última versión es lingüista. Estos cambios obedecen, al parecer, a un intento de establecer las variantes de un mismo relato que ofrezca la visión alucinante de la existencia de los mundos paralelos, como parte del acercamiento pigliano a la literatura fantástica, en la línea de Borges. El propio narrador-personaje menciona, en ambos testimonios, que había leído, en Argentina, esa "novela utópica" (p. 84) donde las parejas de enamorados no pueden encontrarse a causa de un virus propagado por las personas que no son indiferentes para las otras. A la manera de "Tlön, Uqbar, Orbis Tertius", la novela utópica (o ucrónica, de acuerdo con el término de Umberto Eco) representa un universo paralelo, puesto en evidencia en el primer título y disimulado en el

\footnotetext{
${ }^{216}$ Ricardo Piglia, "Notas en un diario. El bar de Scott Fitzgerald", op. cit.

${ }^{217}$ Cfr. también Cuentos morales, op. cit., p. 93.
} 
segundo. Los cambios sugieren que cada testimonio es una versión de un universo paralelo, como "Tlön..." de Borges, "La trama celeste" de Bioy y El hombre en el castillo de Dick.

También es conveniente analizar la profesión de Maggie Stevensen-Erika Turner:

\begin{abstract}
Se dedicaba a las matemáticas. Dirigía el centro de cómputos que controlaba el tráfico aéreo en el aeropuerto de Londres. Una vez le había mostrado el diagrama de los vuelos futuros. Una telaraña interminable de luces que se entreveraban como en un mapa cifrado del universo. Habían manejado la lógica de la incertidumbre de Heisenberg para prever todas las variables inesperadas. Llamamos azar, decía la hermana de Stevensen, a una función elíptica de la temporalidad ${ }^{218}$.
\end{abstract}

En la edición de 2007, la hermana de Stephen se dedica a la lingüística (p. 95). Ambas profesiones se conectan mediante el estudio del lenguaje y la teoría de Heisenberg, que le da un giro fantástico al relato que había iniciado dentro de las convenciones genéricas de la literatura autobiográfica. Al prever los vuelos futuros, como un oráculo que anticipa las acciones aún no decididas por nadie, Maggie cumple una función de doble de su hermano Stephen, quien anuncia una escritura futura donde los movimientos del narrador-personaje Piglia están controlados, como si fuera un autómata. Así, ambos hermanos son estudiosos de los augurios (también en un sentido etimológico): Maggie profetiza el vuelo de las aves mecánicas ${ }^{219}$; Stephen prevé el destino del personaje Piglia desde su "vuelo" de Buenos Aires a París; en su diario, como se vio atrás, Stevensen tiene la "visión" de un profesor de física que profetiza la muerte de los patos al estudiar su vuelo.

\footnotetext{
218 Ibid., p. 90.

${ }^{219}$ La imagen del vuelo y de los aviones como pájaros mecánicos también se relaciona con las réplicas exactas de aves en el tercer capítulo de La ciudad ausente, donde se narra que Russo quedó impresionado por tales inventos y se dedicó a desmontar y estudiar esas máquinas hasta que la policía llegó por él para arrestarlo, pues estaba acusado de portar una identidad y un nombre falsos. En esta novela, uno de los libros que Stevensen ha escrito se llama Pájaros mecánicos, el capítulo de un libro real y el título de una obra imaginaria sugieren una práctica metaliteraria (cfr. La ciudad ausente, op. cit., pp. 98-112).
} 
Por un lado, Stephen es el creador, el artista de la familia, cuya mente linda entre la demencia y la genialidad. Es el rebelde, parecido al retrato del joven artista de Joyce, Stephen Dedalus; pero también es el escritor perseguido por sus obsesiones: se encierra durante meses a ver televisión, se siente tentado a pedir limosna para explicar su aspecto de clochard inglés e incluso sugiere la idea del suicidio ${ }^{220}$. En su apellido, de genealogía cercana (pero al mismo tiempo apócrifa por un cambio fonético) al autor de El extraño caso del Dr. Jekyll y Mr. Hyde, Robert Louis Stevenson, se sugiere el concepto del doble. Su lado oscuro también aparece en múltiples referencias, además de las anteriores: su más reciente novela, según el narrador-personaje Piglia, se llama Jekyl (p. 85). Otro cambio, ahora en la escritura. La ausencia de una 1 forma parte de la red de cambios que enfrenta la realidad con lo apócrifo, para permitir el aterrizaje a lo fantástico ${ }^{221}$. Pero en estos desdoblamientos, quizá el más significativo sea el de su hermana. Si él es el artista, ella es la analista, la científica. Es posible que la oposición entre narración y reflexión sea representada en las figuras de los hermanos. Él es novelista; ella, lingüista. Complementan su experiencia del mundo. Sus experimentos son paralelos, también. Stephen logra que el personaje Piglia cumpla puntualmente el itinerario que él ha escrito en su diario, pensando en las posibilidades de la vida basándose en la teoría de la repetición, tal como lo explica en la hoja manuscrita que deja como al descuido para que el otro lo encuentre:

\footnotetext{
${ }^{220}$ En Wasabi, de Alan Pauls, también se narra una serie de acontecimientos en torno a la esterilidad creativa del protagonista, a quien podemos identificar como el propio escritor argentino a partir de ciertas referencias bibliográficas, como su artículo sobre La traición de Rita Hayworth de Puig. En una relación literaria que tiene en la nouvelle pigliana su hipotexto, la obra de Pauls también se desarrolla en Saint-Nazaire, dentro del programa para escritores y traductores que la Maison y su director Christian Bouthemy -personaje en esta última- establecen para los visitantes extranjeros. Como Stevensen, el personaje "Alan Pauls" tiene una severa crisis creativa; como la estructura de la novela breve de Piglia, Wasabi pasea por los terrenos de la metaficción y la autorreferencialidad (Cfr. Alan Pauls, Wasabi, Anagrama, Barcelona, 2005 (Narrativas hispánicas, 380)).

${ }^{221}$ Por su parte, María Antonieta Pereira sostiene: “Observamos que el cambio o la ausencia de una letra [...] además de indicar un proceso de apropiación, denota la imposibilidad de una identidad perfecta entre esos pares y, por lo tanto, instaura una creación en estado de tensión provocada por tiempos y textos que procuran mantener trazos distintivos mas [sic] que al mismo tiempo se mezclan y se confunden" (op. cit., p. 35.)
} 
Hay que recordar para no repetir. Serie de acontecimientos imperceptiblemente simétricos. En una vida la red de actos exactamente iguales alcanza, digamos, el 73,2 por ciento. Hay que pensar en el resto (los restos), en lo que se filtra por los intersticios de la repetición y sucede una sola vez. En ese punto se construye el jeroglífico donde se cifra el porvenir (p. 87).

Maggie, por su parte, es una lingüista destacada, que ha logrado predecir los vuelos futuros. Su interés principal se centra en la búsqueda del origen de los dichos populares. Se ha acercado a diversas razas y tribus. En el complemento del relato principal, el "Diario de un loco", que al mismo tiempo es el diccionario personal de Stephen, la significativa entrada "Fábula" que remite a la noción de moral (y que conecta con los Cuentos morales) y también a la etimología de relato hablado, contado, así como a las raíces de los relatos antiguos, es decir, los mitos, Stevensen escribe sobre la labor de su hermana:

En verdad trabaja sobre refranes que condensan lecciones de ética popular y busca investigar en archivos y testimonios orales la situación original que dio origen a la moraleja. Ella construye la situación material en la que esa frase ha nacido. Esos dichos son ruinas de relatos perdidos y de escenas reales. Si uno puede reconstruirla, dice, podría conocer la historia de la forma de vida de las clases populares (pp. 123-124).

Lo que uno busca mediante la experimentación y la creación, la otra lo encuentra en la investigación y el análisis de los relatos sociales, de las historias orales que nos remiten, una vez más, a "El narrador” de Benjamin y a la apropiación de máquinas y medios para la lucha revolucionaria. Stephen queda atrapado en sus experimentos y desaparece del relato, tal como se lee en el "Diario de un loco", la ruina del relato de lo que ha quedado del escritor británico y que se convierte, implícitamente, en la herencia que le ha dejado al “argentino". En la definición de "Intriga” se encuentran estas líneas: "Su hermana, en París, 
se prepara para rescatarlo ya que ha desaparecido. Pero es imposible. Se ha perdido en la ciudad. Un clochard. Deambula. Nadie lo puede encontrar. (Al fin lo internan en un hospicio.)" (p. 129) La hermana, por su parte, ha recibido una propuesta de la Universidad de Princeton para estudiar ahí su teoría de los refranes. Al parecer, el genio del hermano se perderá con él; en cambio, Maggie intenta aplicar sus investigaciones a un aspecto que va más allá de las preocupaciones metafísicas de Stephen: la causa social, que ella ha asociado al análisis lingüístico. La búsqueda de los hermanos (los dobles) se basa en la repetición de rutas, acciones y discursos. Sin embargo, es ella quien logrará aplicar sus conocimientos como un aporte a la resistencia social, por lo que se convierte en una conspiradora, en una aliada al complot político. Como Emilio Renzi (alter ego y por lo tanto doble de Piglia, como se ha repetido muchas veces) en "La loca y el relato del crimen"222, Maggie Stevensen (o Erika Turner, cuyo simbólico apellido obliga a pensar, de modo exasperado, en otro desdoblamiento) analiza el lenguaje con una finalidad social, ya que cambia la actividad aparentemente inmanentista del discurso por la persistencia de la memoria: no olvidar para no repetir los acontecimientos atroces de la historia. Si continuamos en la línea de la propuesta de Bratosevich, a propósito de que "Encuentro en Saint-Nazaire" representa la literatura en un modo alegórico, esta literatura se desdobla en los aspectos metafísicos de Stephen y en los aspectos morales y sociales que Maggie intenta llevar a la práctica. En "La loca y el relato del crimen", ante la censura oficial que el director de El Mundo, el viejo Luna, ha ejercido sobre él para no tener problemas con la policía, Renzi decide escribir un cuento que sea una denuncia de los actos de injusticia cometidos sobre los marginados. El método lingüístico, tomado directamente del formalismo ruso y checo, ha trascendido las

${ }^{222}$ Cfr. De la crítica a la ficción..., op. cit., pp. 33-73. En el segundo capítulo estudié la función social del lenguaje en ese cuento de 1975. 
fronteras del discurso oficial (el cafishio mató a la fichera, nada tiene que ver el gordo Almada, protegido por la cúpula gubernamental) y se ha convertido en material para la creación. La resistencia social se encuentra, por lo tanto, en el estudio del lenguaje. Maggie-Erika decide proteger a la chica integrante del IRA, la esconde en su casa y se solidariza, implícitamente, con la causa revolucionaria irlandesa: ya forma parte de un complot contra la política de su nación periférica, lo que la acerca a los conspiradores de Roberto Arlt: Los siete locos que intentan transformar la realidad aunque sea desde una utopía de la ilusión. Dos grandes estudiosos del lenguaje en sus obras, Roberto Arlt y Macedonio Fernández, vuelven a aparecer como escritores subversivos que han logrado captar la falsa ficción del Estado mediante el estudio del discurso político. Por eso, Rose Corral sugiere la capacidad visionaria del autor de Los lanzallamas a partir del análisis que hace de sus crónicas:

La política internacional de finales de los años treinta, dominada por el afán expansionista de los nazis, es leída y reconstruida por Arlt como un escenario en el que deben descifrarse, tras las palabras y los gestos de actores políticos, las motivaciones ocultas que los mueven, las intrigas que urden en la oscuridad. La política es sinónimo de conspiración: un terreno perverso y cínico, un campo de maniobras en donde triunfa el más astuto, el que mejor engaña al enemigo ${ }^{223}$.

Los relatos estatales son puestos en duda cuando los relatos sociales de Arlt, Macedonio y Piglia se activan: grandes estudiosos del lenguaje, los tres escritores crean sus obras en función de una resistencia frente a la realidad construida de modo artificial por el régimen. Al desmontar el discurso oficial, pueden anticiparse las acciones represivas por venir: en Respiración artificial, el gran descubrimiento de Tardewski sobre el encuentro entre Kafka y Hitler es el descubrimiento del horror visto por el que sea capaz de reconocer e interpretar

${ }^{223}$ Rose Corral, op. cit., pp. 161-162. 
sus signos. Por eso, de acuerdo con Rose Corral, la presencia de la astrología es de gran importancia en la obra de Arlt, ya que se relaciona con la intención de las masas alemanas de conocer su futuro, en tiempos de la inminente derrota nazi ${ }^{224}$, por ejemplo. De modo semejante, en la literatura de Philip K. Dick y Piglia están presentes aquellos personajes que consultan el I Ching para conocer su porvenir ${ }^{225}$.

Si en La ciudad ausente Arlt y Dick son leídos de ese modo, en "Encuentro en SaintNazaire", relato salido de la máquina femenina de narrar, Stephen y Maggie, personificaciones de la creación y la reflexión respectivamente, son figuras que han logrado conciliar lo fantástico y lo social en una constante de la poética pigliana. En el gesto clandestino de Maggie (que también instaura un nombre falso y doble: Erika Turner) al ocultar a la mujer del IRA, se encuentra el complot arltiano de Los siete locos y el intento de Macedonio de crear una nueva ciudad de Buenos Aires en Museo de la novela de la Eterna: al enterarse de que su fugaz protegida ha muerto combatiendo en Londres, Erika (así la llama el narrador en la definición de "Hermana" del diccionario-diario, lo que le confiere una clara clandestinidad en un juego de dobles) decidió conservar el pañuelo olvidado por la muchacha "como una ofrenda a la injusticia y a la violencia irracional que dominaba la historia de su país. El pañuelo era una suerte de bandera minúscula de la lucha de la muchacha cuyo nombre nunca supo" (p. 129). Perdida en el anonimato, la lingüista retoma la intención de la lucha nunca realizada por su padre (un nacionalista irlandés) mediante el estudio de sus dichos en Princeton. Así, se cumple lo que Karl Kohut menciona a propósito no de la literatura comprometida (en el sentido sartreano), sino de la literatura de la memoria en Piglia: escribir para dar testimonio y memoria, alejándose además del

\footnotetext{
${ }^{224}$ Ibid., p. 163.

${ }^{225}$ Supra, pp. 60-72.
} 
estereotipo del escritor comprometido a la manera de los autores del Boom ${ }^{226}$. Los recursos literarios del escritor argentino, entre los que destaca el cultivo del género fantástico, son procedimientos revolucionarios porque cambian los modos de leer, proponiendo una manera de sobrevivir ante los ataques físicos, lingüísticos e ideológicos del Estado. Al desmontar el discurso gubernamental, los escritores ponen en evidencia las falacias transmitidas en cadena nacional. Para Piglia, el lingüista siempre es revolucionario. Por eso, la mención a Noam Chomsky, crítico del sistema geopolítico estadounidense, al final de Tres propuestas para el próximo milenio (y cinco dificultades), cobra una relevancia retrospectiva, actual y futura:

\footnotetext{
No me parece nada raro entonces que el mayor crítico de la política actual (uno de los pocos intelectuales realmente críticos en la política actual) sea Chomsky: un lingüista es por supuesto el que mejor percibe el escenario verbal de la tergiversación, la inversión, el cambio de sentido, la manipulación y la construcción de la realidad que definen el mundo moderno ${ }^{227}$.
}

\subsection{Entre el tema del doble y lo múltiple}

No cabe duda que la máquina de narrar de La ciudad ausente es, quizá, el proyecto literario más experimental y complejo en la obra de Piglia. La estructura de la novela, así como la multiplicidad de historias, entrecruzadas en sus referencias, propone una lectura que escapa a cualquier convención artística, sin dejar de insertarse en una tradición literaria representativa del Río de la Plata, la literatura fantástica y las prácticas metaficcionales, en

\footnotetext{
${ }^{226}$ Karl Kohut, “¿Literatura comprometida o literatura de la memoria?”, en Rose Corral (ed.), op. cit., pp. 128 y 132.

${ }^{227}$ Ricardo Piglia, Tres propuestas para el próximo milenio (y cinco dificultades), op. cit., p. 40.
} 
diálogo permanente con los géneros considerados, aún, marginales, como el policial (en Piglia lo policial siempre tiende a la novela negra) y la ciencia ficción.

En este contexto, las abundantes referencias intratextuales o autorreferenciales que circulan en todos los relatos, novelas, ensayos y entrevistas de Piglia sugieren una poética de la repetición, una poética donde las múltiples versiones de un relato crean una realidad alterna que niega nuestra realidad convencional, ajustada por los conceptos filosóficos occidentales. La desautomatización literaria, que produce un efecto de shock en los lectores, postula una poética de la resistencia social que tiene su base en los recursos literarios, muchas veces incomprensibles para los ciudadanos no habituados a la lectura, es decir, los ciudadanos controlados por los medios aliados y fieles al gobierno autoritario y patriarcal. Quizá el caso más claro de la interpretación anterior sea el relato "La isla", la última narración de Elena en la novela de 1992. Todas las lenguas convergen en el sitio destinado para la consolidación de una nación utópica, a la que han llegado todos los outsiders del planeta. Los cambios lingüísticos que se producen diariamente, y en los cuales, inclusive, se pierden para siempre vocablos, frases, dichos populares y lenguas, son un intento de desestancar la tendencia a lo monolítico, emblema de los gobiernos que buscan toda suerte de reformas para que nada cambie. Sólo permanece Finnegans Wake, la novela más experimental de Joyce, considerada una especie de Biblia en ese lugar utópico. En un escenario así, resulta justificable que la lingüística sea la ciencia fundamental.

En el capítulo dedicado a La ciudad ausente, hemos visto que los relatos metaficcionales analizados, que se insertan en la estructura narrativa de la máquina, aluden también a esta, pues también habla de sí misma. El origen del primer relato creado por la máquina es también un relato autorreferencial en un doble sentido: ha salido de Elena y habla de sí mismo. Ese relato originario, que funda una práctica creadora de finalidad social 
y que trasciende la modesta función traductora de la máquina, aparece como Stephen Stevensen en la novela y se llama "Encuentro en Saint-Nazaire" en su versión completa.

Si "La isla" clausura los relatos de la máquina en el marco espacial del libro, Stephen Stevensen los inaugura ${ }^{228}$ :

\begin{abstract}
Una tarde le incorporaron William Wilson de Poe para que lo tradujera. A las tres horas empezaron a salir las cintas de teletipo con la versión final. El relato se expandió y se modificó hasta ser irreconocible. Se llamaba Stephen Stevensen. Fue la historia inicial. Más allá de sus imperfecciones sintetizaba lo que vendría. La primera obra, había dicho Macedonio, anticipa todas las que le siguen $^{229}$.
\end{abstract}

Sin duda alguna, esta referencia intertextual sobre Poe en la narrativa de Piglia tiene relación con el tema del doble ${ }^{230}$, que a su vez se desdobla en otro relato cuyo título es mucho más revelador: Stephen Stevensen, y que mantiene la aliteración formada por el nombre William y el apellido Wilson. En el desdoblamiento del texto, la relación intertextual se produce con la literatura británica: Stephen nos remite al artista Dedalus de Joyce; Stevensen claramente nos recuerda a Stevenson y su relato fantástico más importante: El extraño caso del Dr. Jekyll y Mr. Hyde. En los que podríamos llamar hipotextos del relato de Piglia, se repite, una vez más, el tema del doble, todo un leitmotiv en la literatura fantástica, que Piglia también ha puesto de manifiesto en otras obras, no como tema, sino como procedimiento.

\footnotetext{
${ }^{228}$ Curioso el empleo de las cursivas para el primer relato de la máquina, como un intento de subrayar su importancia, y como un guiño a la literatura del siglo XIX, tan propensa a poner énfasis como guía a los lectores. Los cuentos de Poe y Hoffmann pertenecen a esta práctica. El resto de los relatos ("La grabación", "La isla", "El gaucho invisible", etc.) van entre comillas.

${ }^{229}$ Ricardo Piglia, La ciudad ausente, op. cit., p. 41.

${ }^{230}$ Para el análisis del tema del doble en Poe y Piglia, cfr. María Antonieta Pereira, op. cit., pp. 77-81, y Jesús Eduardo García Castillo, "Conversación ausente en la ciudad al sur: silencio y circunlocución como estrategias mnemotécnicas en las obras de Ricardo Piglia y Marta Traba”, Signos literarios, v. V, núm. 9, enero-junio de 2009, pp. 75-92.
} 
En el análisis del tema del doble, es pertinente la lectura del artículo de Eduardo García Castillo, del prólogo de Jorge Carrión a su recopilación crítica y del capítulo que José Manuel González Álvarez le dedica a la nouvelle en su libro. En el caso del primero, la relación establecida entre "William Wilson" y La ciudad ausente le permite al autor indagar en el concepto de memoria, en el marco de la época posterior a la dictadura. En los textos de Carrión y González, por otro lado, se hace un repaso de la obra de Piglia (en el libro del segundo crítico, de modo particular, se enumeran los dobles que aparecen en la novela breve) a partir del simbólico número dos para ilustrar su importancia en los personajes pares ("gemelos, hermanos, usurpadores de personalidad, dobles, etc.), en relación con su poética ${ }^{231}$. Sin embargo, La ciudad ausente postula un "más allá" de una práctica dual.

En su repaso por el tema del doble en la literatura decimonónica, María Antonieta Pereira habla de los descubrimientos científicos de la época en el contexto de una sociedad tendente al binarismo y, por lo tanto, a la exclusión del diferente, del otro. Por eso, en el siguiente siglo, "la virtualidad de lo real y la inestabilidad de las verdades científicas exigen una nueva lectura del mundo, en la cual la dualidad cede lugar a la heterogeneidad: no hay sexo, raza o cualquier otro objeto en estado puro, sino en mezcla permanente" 232 .

Más que el número dos como símbolo de la novela, es la fragmentariedad y la multiplicidad de voces y relatos lo que determina la lectura de esta obra. Al aludir a Poe, Stevenson y Joyce, Piglia no solo se inserta en la tradición fantástica, también propone una salida de las lecturas convencionales que cambie los modos rígidos del pensamiento

\footnotetext{
${ }^{231}$ Jorge Carrión, "Dos por dos: la multiplicación pigliana. Prólogo" a El lugar de Piglia, op. cit., pp. 9-23, y José Manuel González Álvarez, op. cit., pp. 135-137.

${ }^{232}$ María Antonieta Pereira, op. cit., p. 80.
} 
común. En su cercanía con el género fantástico, la ciencia ficción comparte una función social:

Quizá en el ciencia ficción ese trabajo con el futuro (la literatura no sólo trabaja con el presente y el pasado) se ha hecho más nítido. La dimensión utópica: el futuro actúa como una crítica al presente, es un tipo de literatura social, por lo tanto; se toma un punto y se amplifica, como ocurre por ejemplo con la novela de Ursula K. Le Guin, La mano izquierda de la oscuridad, donde la gente cambia de sexo, cíclicamente, como crítica a los lugares fijos, a las funciones sociales y sexuales inmóviles ${ }^{233}$.

Si Stephen Stevensen es la traducción deformante del cuento de Poe, su Mr. Hyde, podríamos decir, es porque el hipertexto se convierte en una obra de arte autónoma, con muchas posibilidades de interpretaciones, trascendiendo la lectura decimonónica.

Para Francine Masiello (que, en la línea interpretativa de Pereira, también entiende que el yo ataca al otro, al diferente, de acuerdo con la posición binaria del siglo XIX), el concepto de traducción en la literatura de Ricardo Piglia tiene un sentido menos académico que de resistencia social: "Piglia concibe la traducción como un modo de dislocar el poder del Estado concebido como un depósito donde se almacenan los conocimientos. La traducción reorienta la información y cambia las condiciones para el arte y la identidad individual"234. La acción más subversiva de Macedonio, en la novela, es la de crear una máquina que cuente los relatos de aquellos hombres de las pampas que se iban muriendo. La sustitución tecnológica ubica en el trasfondo de su metáfora a Walter Benjamin, que en "El narrador" estudia los relatos orales como símbolo de las culturas que resisten los cambios emprendidos por el capitalismo ${ }^{235}$ y en "La obra de arte en la época de su

\footnotetext{
${ }^{233}$ Jorge Carrión, "No hay que tomarse en serio a ningún escritor. Entrevista con Ricardo Piglia”, en El lugar de Piglia, op. cit., pp. 424-425.

${ }^{234}$ Francine Masiello, op. cit., p. 262.

${ }^{235}$ Walter Benjamin, "El narrador", Para una crítica de la violencia y otros ensayos, Taurus, Madrid, 1991.
} 
reproductibilidad técnica" postula que los medios deben estar al servicio de la revolución ${ }^{236}$. Cuando la máquina deja de traducir para transformar y re-crear, se produce el acontecimiento literario capaz de mostrar las formas de la resistencia social. Y es que precisamente Masiello, en la línea de Nelly Richard, Beatriz Sarlo y el autor de los Pasajes, lee en la obra pigliana la unión de los procedimientos vanguardistas con la defensa del espacio político, usurpado por la clase gobernante:

A lo largo de La ciudad ausente, los personajes buscan una comunidad para hacer que la otredad sea legible en el ámbito de la vida cotidiana. Esto se apoya en una preferencia por los nómade donde los personajes flotan entre los objetos y los acontecimientos en busca de un lenguaje común derivado de la traducción. Deleuze y Guattari en Las mil mesetas [...] hablan de la máquina del Estado que valoriza las oposiciones binarias del pensamiento, frecuentemente rígidas y limitantes [...] Y en la medida de que las máquinas [de imitación y de invención, como Elena] siempre traducen de una lengua a otra, facilitan la comunicación subversiva que elude la vigilancia del Estado mercantil. En este caso, la traducción sirve para valorizar la estética y las relaciones de los individuos con la comunidad $^{237}$.

Esta resistencia social, en donde la traducción se convierte en uno de sus pilares, es representada de un modo menos alegórico en la figura de Roberto Arlt, lector de las versiones populares que las editoriales modestas hacían de los escritores rusos, verdadera materia prima para el autor de El juguete rabioso ${ }^{238}$.

${ }^{236}$ Walter Benjamin, "La obra de arte en la época de su reproductibilidad técnica”, op. cit.

${ }^{237}$ Francine Masiello, op. cit., p. 263.

${ }^{238}$ En "Nombre falso", la nouvelle que gira en torno de un supuesto texto inédito de Roberto Arlt, Kostia, su amigo, le comenta al "personaje" Ricardo Piglia: "¿Sabe de quién fue testigo Arlt?: de Edgar Sue, de Rocambole, de esos tipos. Leía como loco: todo en las traducciones de Tor. ¿Se ubica? Jamelgo, mozalbete; eso era la gran literatura para él [...] Dostoievski pasado por los traductores gallegos. ¿Sabe por qué era genial Arlt? Porque se dio cuenta de que ahí había un estilo. Después los boludos dicen que escribía mal" (Nombre falso, op. cit., pp. 140-141). Por su parte, Rose Corral interpreta el acercamiento de Arlt a las traducciones populares de los escritores rusos como un gesto político que lo diferencia de la alta cultura elitista de Buenos Aires, ya que denuncia "un colonialismo mucho más pernicioso que el de los modelos extranjeros, un colonialismo cultural interno que establece cortes y separaciones, sociales y culturales, entre los que leen en el idioma original y los que leen en traducciones, o sea la gran mayoría de los escritores argentinos de origen inmigratorio. Como bien lo capta Arlt en esos años, las traducciones constituyen un factor de democratización 
La transformación de "William Wilson" a Stephen Stevensen se produce de un modo delirante. En La ciudad ausente solo conocemos unos cuantos fragmentos del relato. No es sino hasta la publicación de los Cuentos morales de 1995, que puede leerse "Encuentro en Saint-Nazaire", aunque de modo incompleto. La novela de 1992 anunciaba ya el relato inédito que iba a aparecer en la antología tres años más tarde. Los relatos de la máquina han excedido el marco de la novela-libro que la contiene y ha traspasado todos los límites, como en el universo de Tlön. En su giro en espiral, la máquina termina asimilando todos los relatos.

De acuerdo con lo anterior, hay en Piglia una intención de crear espacios de resistencia social, donde lo fantástico, las referencias eruditas a la cultura (un túnel difícil de transitar para los guardianes de la ley) y la intertextualidad (que es también un modo culto de establecer relaciones que escapen a los ojos de vigilantes y censores, como Arocena) son prácticas con una función social totalmente definida. Por eso, aunque Masiello acierta en su interpretación de la función de los recursos poéticos que el autor de Respiración... emplea para salir del control estatal, como la multiplicidad y la fragmentariedad narrativas, las figuras poéticas y retóricas que emplea, como la parodia, la autorreferencialidad y la paradoja, no son exclusivas de una práctica poética posmoderna, como esta crítica las adjudica a la escritura de César Aira (a quien encuentra como un "formidable posmoderno" ${ }^{\text {239 }}$ ), sino que son, a mi juicio, una constante que supera cualquier intento de etiquetar la literatura en corrientes, escuelas o movimientos. En este sentido, los recursos piglianos no son posmodernos en el sentido al que Masiello se refiere a estos, sino parte de una tradición literaria que proviene, en primer lugar, de Borges. Sin ser totalmente fiel a esa

en el acceso a la cultura" (Rose Corral, "Una poética de la disonancia", en Roberto Arlt. Una poética de la disonancia, op. cit., p. 24).

${ }^{239}$ Francine Masiello, op. cit., p. 36. 
tradición, Piglia logra una síntesis de lo aparentemente inmanente (como todavía se afirma a propósito del género fantástico) con el compromiso social. En Piglia, por lo tanto, los recursos que Masiello llama posmodernos cumplen con una función social que permite abrirle a la literatura una salida del vacío intelectual de nuestros días y de los regímenes autoritarios y sus “modelos rígidos de representación”. En la línea de la evolución literaria de los formalistas rusos, precursores y contemporáneos de muchas ideas que Mijaíl Bajtín, Walter Benjamin y otros estudiosos más fueron desarrollando a lo largo del siglo XX, la parodia, la autorreferencialidad, la intertextualidad, el pastiche, el cruce de géneros, aún no han agotado sus posibilidades, todavía no han sido automatizados por los lectores contratados por el Estado para servir de censores, espías y guardianes de los cánones institucionalizados.

\subsection{El Aleph de Piglia}

Cronológicamente, "Encuentro en Saint-Nazaire" fue escrito, según Piglia, en 1988, de acuerdo con la "Nota" de Prisión perpetua (p. 149). En mi entrevista, el autor argentino afirma que terminó La ciudad ausente en $1990^{240}$. La cercanía de fechas de creación y publicación no solo ponen de manifiesto que ambas obras son parecidas temáticamente y estilísticamente, sino también que Piglia estaba pensando en el cruce de ambas historias y en sus modos de expresión y representación. La presencia del género fantástico es latente y, aunque el giro a lo fantástico data de los años noventa, su gestación se produce unos cuantos años atrás.

Si es altamente significativo que Piglia haya decidido cambiar los títulos de las obras de Stevensen y la profesión de Maggie en las últimas ediciones de "Encuentro...”, quizá lo

\footnotetext{
${ }^{240}$ Infra, p. 183.
} 
sea más comparar la narración de Stephen Stevensen, dentro de La ciudad ausente, con la nouvelle en la que el relato se convirtió.

Encerrado varios días para estudiar los relatos de la máquina, Junior decide volver a Stephen Stevensen, ya que se trata del primero. "Ya estaba todo ahí. El primer texto mostraba el procedimiento. Tenía que buscar en esa dirección. Investigar lo que se repetía"241. Como Emilio Renzi en "La loca y el relato del crimen", Junior intenta llegar a un mensaje cifrado a través de todo lo que se repite en el cuerpo del texto. La ciudad ausente anuncia el relato que vendrá: el primer texto literario de la máquina de narrar sugiere la expansión de la creación literaria a todos los espacios: la novela ha absorbido la realidad y la ha transformado. En realidad, "Encuentro en Saint-Nazaire" es un relato expulsado de la máquina.

Los puntos de contacto entre novela y nouvelle son abundantes. La repetición de frases establece sin lugar a dudas la relación intratextual. La historia se repite: un hombre logra que otro, el que narra los acontecimientos, actúe bajo su influjo, dentro de un experimento donde la escritura funciona como un oráculo. Los cambios entre la novela de 1992 y el relato de 1995 (en su primera versión al español) son nominales y espaciales, principalmente. En la primera, las acciones del narrador se encuentran en la órbita de la nación argentina; en la nouvelle, como el título lo indica, las acciones ocurren en Francia. Para María Antonieta Pereira, lo anterior ofrece el trayecto de un boomerang a propósito de las primeras ediciones y versiones de ambos textos: como si Piglia estableciera "un circuito idiomático y cultural peculiar, en el cual se pueden suponer sucesivas traducciones: del español al francés y del francés de nuevo al español"242.

\footnotetext{
${ }^{241}$ Ricardo Piglia, La ciudad ausente, op. cit., p. 97.

${ }^{242}$ María Antonieta Pereira, op. cit., p. 37.
} 
El primer nexo entre ambos relatos aparece en un párrafo donde Stephen Stevensen se presenta (con comillas para indicar que se trata de una re-producción) a sí mismo, mientras que la voz del narrador explica las palabras del primero entre paréntesis:

"Me llamo Stephen Stevensen. Soy nieto y bisnieto y tataranieto de marinos. Sólo mi padre fue un desertor y por eso vivió toda la vida con la misma mujer y murió como un miserable en Dublín. (El padre de Stevensen se había negado a entrar en la marina británica quebrando la antiquísima tradición familiar y se había convertido en un nacionalista irlandés. La madre era de ascendencia polaca. Una mujer sarcástica y elegante que pasaba los veranos en Málaga o en el British Museum.) Stevensen había nacido en Oxford y todas las lenguas eran su lengua materna. Tal vez por eso creí la historia que me contó y por eso estoy aquí, en esta estancia perdida. Pero si la historia que me contó no es cierta, entonces Stephen Stevensen es un filósofo y un mago, un inventor clandestino de mundos como Fourier o Macedonio Fernández ${ }^{\text {,243. }}$.

En el segundo y el tercer párrafos de "Encuentro en Saint-Nazaire", después de que el narrador-personaje (a quien más tarde reconoceremos como "Ricardo Piglia", "el argentino") se presenta en el texto, mencionando que ha vuelto a Saint-Nazaire para pedirle explicaciones a Stevensen, puede leerse lo siguiente:

\footnotetext{
"Soy nieto y biznieto y tataranieto de marinos", me dijo un día. "Sólo mi padre rechazó el mar y por eso vivió toda la vida con la misma mujer y murió miserablemente en un hospicio, en Dublín." (El padre de Stevensen se había negado a entrar en la marina británica quebrando una antiquísima tradición familiar y se había dedicado al comercio de pieles. La madre era de ascendencia polaca. Una mujer sarcástica y elegante que pasaba los veranos en Málaga, o en el British Museum.)

Nunca he conocido a nadie que hable como Stephen Stevensen. Todas las lenguas son su lengua materna. A veces pienso que por eso le creí la historia que me contó y por eso estoy aquí, en SaintNazaire. Pero si la historia que me contó no es verdadera entonces Stephen Stevensen es un filósofo y un mago, un inventor clandestino de mundos como Fourier o Macedonio Fernández (pp. 81-82).
}

${ }^{243}$ Ricardo Piglia, La ciudad ausente, op. cit., pp. 97-98. 
Los cambios llevados a cabo por el autor argentino responden, en parte, a las necesidades de cada texto. El primero es un metarrelato, enmarcado en las narraciones de la máquina (lo que explica la presencia de las comillas finales, que abarcan todo el inicio del relato). El segundo es una nouvelle que, aparentemente, es independiente de la historia que la originó. Pero lo que permanece también es importante, como la mención a Fourier y su creación del falansterio como un proyecto utópico (también mencionado por Walter Benjamin en "París, capital del siglo XIX") y a Macedonio, el creador de la máquina de narrar, de la que, por lo tanto, ha salido toda la literatura posterior.

Stephen Stevensen se extiende poco más de una página en La ciudad ausente, después de mi cita. La historia, que los lectores hemos leído de modo incompleto, llega hasta poco antes de la lista de objetos y libros dejados por el demiurgo europeo en la casona en la que el "médico (y escritor)"244 anónimo se ha establecido. Solo se nos ha dado el comienzo del relato, a diferencia de tantos más que los lectores, al lado de Junior, hemos podido conocer en la visita al Museo. Este relato no es leído en el Museo; sin embargo, el vértigo de la lectura que cruza distintos planos y niveles narrativos se produce nuevamente, cuando el periodista "encontró un saco de cuero, que colgaba de una percha en un ropero de campo. Encontró una lupa, un horario de trenes, un anillo con un monograma y una barra de lacre. En el escritorio estaba el borrador de una segunda página de una carta de Stevensen $[\ldots]^{, 245}$. Si Junior se había encerrado en su habitación, ¿en dónde encontró todo esto? ¿Lo encontró en un sentido metafórico, al leer? ¿O se ha perdido en el cuerpo del texto, como el protagonista de "Continuidad de los parques" de Cortázar? Pudo haber visitado nuevamente

\footnotetext{
${ }^{244}$ Ibid., p. 99.

${ }^{245}$ Ibid., p. 100.
} 
el Museo para captar estos y otros detalles, pero el texto nunca es exacto en este punto ${ }^{246}$. En la línea de lo fantástico y del cruce entre la realidad y la ficción, como ya se señaló anteriormente, Junior es un personaje más de la máquina, y esta ha terminado por absorberlo: "Junior, ese flâneur o detective alucinado, se extravía al perseguir las huellas difuminadas del entramado social, porque la ciudad es una máquina de fabular heterotopías" ${ }^{247}$. La estructura metadiegética de la novela abre la posibilidad de interpretar los acontecimientos en el marco del género fantástico. Si el relato que en La ciudad ausente se llama Stephen Stevensen se muestran de modo explícito los procedimientos metaficcionales, en "Encuentro en Saint-Nazaire", la versión completa de aquel hipotexto, dichos procedimientos se llevan a cabo hasta la exasperación, en una mise en abyme que postula una poética de lo fantástico y la crítica social.

Como en las nouvelles anteriores de Piglia, "Nombre falso" y "Prisión perpetua", en "Encuentro..." existe una superposición de fragmentos que corresponden a diversos géneros: el diario, las cartas, relatos incompletos, citas, descripciones de fotografías, etc. Sin que esas obras sean fantásticas en algún sentido, la atribución errónea de un manuscrito a Roberto Arlt y la aparición de un personaje aparentemente histórico como Steve Ratliff permiten el cruce entre lo real y lo ficcional, en un gesto borgiano que confunde estos conceptos y pone en duda las estructuras en las que descansa nuestra cultura.

Una vez establecido el cronotopo del relato (el personaje Piglia que llega a SaintNazaire), lo que en un principio pudo haberse leído como un texto autobiográfico poco a

\footnotetext{
${ }^{246}$ Otro ejemplo de la estructura metadiegética de la novela, que aquí puede servirnos para pensar en el autor Piglia comp personaje perseguido por Stevensen: "yo pienso que el narrador-investigador, Junior, es también un personaje de la máquina; me parece que ella construyó ese personaje que viene a salvarla" (Jorge Ariel Madrazo, "Entrevista a Ricardo Piglia", Atenea, (Concepción, Chile), núm. 473, 1996, p. 104).

${ }^{247}$ Edgardo H. Berg, op. cit., p. 83.
} 
poco se va transformando en un relato del género fantástico ${ }^{248}$. Los guiños al lector son también intratextuales, no solamente por su enorme parecido con el relato que hace el médico-escritor en Stephen Stevensen, sino también por otras referencias. Una de estas establece relación con "Nombre falso": en el cuaderno de Roberto Arlt que el personaje Piglia tiene en su poder, se encuentra un apunte para un cuento que el autor de $E l$ jorobadito supuestamente iba a escribir: en la atribución "errónea" que Piglia establece y que desde luego anuncia el engaño final, el de "Luba", relato de Andreiev atribuido falsamente a Artl (y que en realidad se llama "Las tinieblas"), ese breve argumento pertenece a Nathaniel Hawthorne, según los Cuentos breves y extraordinarios de la antología de Borges y Bioy.

El argumento habla de un enemigo que se revela como tal, en un final funesto para el protagonista. Arlt, en "Nombre falso", ha escrito ese argumento, pero en realidad se trata de un guiño borgiano al lector, por parte de Piglia ${ }^{249}$. En los mismos argumentos atribuidos a Hawthorne, en la antología mencionada, se lee otro más, tomado de sus Note-books de 1868 y cercano a la anécdota de "Encuentro en Saint-Nazaire": "Un hombre de fuerte voluntad ordena a otro, moralmente sujeto a él, la ejecución de un acto. El que ordena

${ }^{248}$ En las tres nouvelles piglianas, el autor argentino aparece como personaje y narrador. Este procedimiento es identificado por José Manuel González con el nombre de "autoficción", uno de los ejes de su investigación y un concepto polémico. En todo caso, el empleo de esta práctica, en la obra de Piglia, lo coloca, como lo hemos dicho aquí -y como también González lo reitera en numerosas ocasiones- en la genealogía literaria que tiene en la figura de Borges a uno de sus precursores, y que funciona, en nuestra investigación, como una presencia que anuncia el acontecimiento fantástico. Este procedimiento es fantástico por su forma especular: siguiendo a Dällenbach en su análisis del sujeto enunciador y del objeto enunciado, en "Encuentro...", el sujeto Piglia poco a poco deja de ser el narrador (y el sujeto) para transformarse en el objeto del experimento y en el objeto narratario. Llego a esta conclusión a partir de las reflexiones del autor de El relato especular sobre la novela Heinrich von Ofterdingen de Novalis: "Además de poner de manifiesto que, ahora, los papeles se han invertido, y que el libro inserto, antes objeto, es ahora sujeto y clave de interpretación de la novela, este recuerdo de una presagio en camino de cumplirse desvela una estrategia en la que estamos adentrándonos, consistente en ir agrediendo una y otra vez el orden cronológico, hasta lograr que se disuelva, permitiendo que pasado, presente y futuro se hagan reversibles" (Lucien Dällenbach, op. cit., p. 86. Para el estudio de la autobiografía y el concepto de autoficción, cfr. José Manuel González Álvarez, op. cit., pp. 28-31).

${ }^{249}$ Cfr. el análisis que Jorge Fornet lleva a cabo en El escritor y la tradición, op. cit., pp. 23-59, y en "Homenaje a Roberto Arlt o la literatura como plagio", Nueva Revista de Filología Hispánica (México), t. XLI, núm. 1, 1993, pp. 279-291. 
muere y el otro, hasta el fin de sus días, sigue ejecutando aquel acto"250. En este juego intertextual de citas desviadas, Piglia une este argumento a otro más del autor de Wakefield, mediante el empleo del paréntesis:

Un hombre en la vigilia piensa bien de otro y confía en él plenamente, pero lo inquietan sueños en que su amigo obra como un enemigo mortal. Se revela al final que el carácter soñado es el verdadero. (En medio de la multitud, en la jungla de la ciudad, imaginar a un hombre cuyo destino y cuya vida están en poder de otro, como si los dos estuvieran en un desierto. $)^{251}$

En realidad, lo que aparece entre paréntesis es el segundo argumento de Hawthorne ${ }^{252}$; esto puede contribuir a una interpretación en la cual Piglia termina uniendo tres argumentos que se concretan en "Encuentro en Saint-Nazaire" para sugerir, con este procedimiento intertextual e intratextual, dos entradas a lo fantástico: una es temática, cara a dos de los grandes representantes de la literatura fantástica, Borges y Bioy; otra es formal, debido a la estructura metadiegética, pues este procedimiento es, prácticamente, una apropiación que hace esa tradición literaria en el Río de la Plata. Tal parece que Piglia ha desarrollado los argumentos de Hawthorne en "Encuentro en Saint-Nazaire", texto trabajado, obviamente, a partir de su proyecto estético y su propio canon literario ${ }^{253}$.

\footnotetext{
${ }^{250}$ Jorge Luis Borges y Adolfo Bioy Casares, "Argumentos anotados por Nathaniel Hawthorne”, Cuentos breves y extraordinarios, op. cit., p. 22.

${ }^{251}$ Ricardo Piglia, Nombre falso, op. cit., p. 104.

${ }^{252}$ El primer argumento enumerado por Borges y Bioy: "Un hombre, en la vigilia, piensa bien de otro y confía en él plenamente, pero lo inquietan sueños en que ese amigo obra como enemigo mortal. Se revela, al fin, que el carácter soñado era el verdadero. La explicación sería la percepción instintiva de la verdad". El segundo dice: "En medio de una multitud imaginar a un hombre cuyo destino y cuya vida están en poder de otro, como si los dos estuvieran en un desierto" (Ibidem).

${ }^{253}$ En esta práctica constante de su poética, que consiste en atribuir "erróneamente" citas a otros escritores, y que por supuesto lo enlaza con la literatura de Borges, puede afirmarse que la selección de estos argumentos de Hawthorne son representativos de la poética de la "expresión de la irrealidad" en ambos escritores argentinos: al adjudicar a Roberto Arlt unas anotaciones o esbozos de cuentos del autor de La letra escarlata, Piglia remite, indirectamente, a la pequeña antología mencionada de Borges y Bioy pero, también, como lo indica José Manuel González, al ensayo "Nathaniel Hawthorne" del autor de El Aleph: en este texto, se enumeran los argumentos que el escritor estadounidense dejó en sus cuadernos, entre los que sobresale el
} 
Si esta novela breve se lee bajo la influencia de estos antecedentes literarios de la poética de Piglia, que tiene en "Nombre falso" uno de sus momentos literarios culminantes, puede profundizarse en la sustitución de la personalidad como un elemento propio de la literatura fantástica, sobre todo porque en aquella nouvelle está presente, en todo momento, la ambigüedad del relato en las figuras del personaje Piglia con Stevensen. Para Harry Belevan, uno de los rasgos de lo fantástico es, justamente, la sustitución de una persona, pues esto implica la desaparición completa de la antigua personalidad ${ }^{254}$. Desde esta perspectiva, puede interpretarse "Encuentro en Saint-Nazaire" como un relato fantástico cercano al tema de lo siniestro; a partir de ahí, el concepto de döppelgänger, que nuevamente establece la relación con "William Wilson” y El extraño caso del Dr. Jekyll..., es una referencia más en la temática y la poética piglianas. Sin embargo, las alusiones intertextuales van más allá del simple estudio de las fuentes literarias: parece, más bien, que se trata de una referencia implícita a los relatos-espejo, a la literatura especular o autorreferencial. De esta manera, no es gratuita la referencia de Belevan al Nouveau Roman, después de hablar de la sustitución de la personalidad: "Podría también recordarse aquí la mise en abîme literaria -concepto clave en la obra de Michel Butor y, por extensión, en la reciente novelística francesa- por la cual una suerte de insurrección sicológica y

citado arriba. Las citas poco a poco llevan al autor y a los lectores a los linderos de la literatura especular que deviene en fantástica, fundamental en el estilo de Borges. Al final, este asocia los argumentos a Pirandello y Gide y cierra esa parte del ensayo remitiéndose, implícitamente, a "Magias parciales del Quijote", sobre todo al mencionar los nombres de algunos de las grandes obras especulares: La Eneida, el Quijote... Conocedor de ambas versiones y de los cruces entre lo real y lo ficcional en la literatura borgiana, Piglia ofrece, en "Nombre falso", otra pista oculta que nos remite a la combinación de esos planos: los argumentos recopilados en Cuentos breves y extraordinarios datan, según los autores, de 1868; en el ensayo de Borges, el año es 1838 (además, refiere que Hawthorne falleció en 1864). El "error" sugiere la invención oculta detrás de la supuesta labor filológica, tal como sucede en la primera nouvelle de Piglia (cfr. Jorge Luis Borges, "Nathaniel Hawthorne", Nueva antología personal, op. cit., pp. 172-192, y José Manuel González Álvarez, op. cit., p. 227).

${ }^{254}$ Harry Belevan, op. cit., p. 34. 
poética corroe el mundo cotidiano, el universo explicable de todos los días, basculando un antiguo orden por otro enteramente nuevo"255.

A partir de estas palabras, Belevan se propone entender el género fantástico desde el estudio del lenguaje: toda obra literaria, construida con palabras, es un edificio que permite la posibilidad de lo fantástico: crea imágenes totalmente reales. Por eso, una de las tesis que hace Belevan hace suya en su estudio, corresponde a la teórica Irène Bessière, quien sostiene: "La ficción fantástica fabrica así otro mundo, con palabras, con pensamientos y con realidades que son de este mundo" ${ }^{, 256}$.

En La ciudad ausente, el científico Russo, al que algunos personajes identificaban en la figura de Richter, cuenta que este logró verderle a Perón la idea de que podía fabricar una bomba atómica en la Argentina. Russo afirma: "Nadie puede comparar mi descubrimiento con el invento de Richter, que le construyó a Perón una fábrica atómica sólo con palabras, con la sola realidad de su acento alemán" ${ }^{, 257}$. El poder de la palabra es tal, que Perón construye edificios y galerías subterráneas para la creación de su bomba. "Le creyó su historia fantástica y la defendió hasta el fin. En el fondo es lo mismo, quiero decir que para Macedonio ése ha sido el principio constructivo de la máquina. La ficción de un acento alemán. Todo es posible, basta encontrar las palabras"258. Cabe señalar que, en toda la historia, otro problema que Junior debe investigar es la identidad del científico que, como en las películas de ciencia ficción, ha construido un artefacto peligroso. La suplantación de la identidad es otro de los temas de la literatura fantástica: Russo es Russell en el "Prólogo"

\footnotetext{
${ }^{255}$ Ibid., pp. 34-35. En la cita anterior, el gerundio proviene de la palabra bascular, concepto de Belevan que propone, en parte, como equivalente al concepto de desrealidad (umheimliche) en Freud y al de dubitación en Irène Bessière (p. 55).

${ }^{256}$ Ibid., p. 54.

${ }^{257}$ Ricardo Piglia, La ciudad ausente, op. cit., p. 140.

${ }^{258}$ Ibid., p. 141.
} 
a El último lector $^{259}$; a Russo lo confunden con Richter y también se confunde su nacionalidad: "nadie le dijo que Russo no era ruso sino húngaro, que era ingeniero y había estudiado con Moholy-Nagy"260; pareciera que, gracias a la observación de Belevan sobre la sustitución de la identidad, el trasfondo real de lo fantástico se ubica en el lenguaje, que puede construir mundos alternativos, lejanos de la realidad atroz mediante la creación verbal.

En este sentido, la autorreferencialidad literaria es una variante de la función metalingüística del lenguaje. "Un relato no es otra cosa -afirma Russo- que la reproducción verbal. Una réplica de la vida, si la vida estuviera hecha sólo de palabras"261.

En la literatura de Ricardo Piglia, el estudio del lenguaje es una de las preocupaciones fundamentales. Renzi se dedica a la lingüística; la hermana de Stephen, Maggie, también es lingüista, como ya vimos. Incluso, los científicos, como Russo, reconocen que el lenguaje se encuentra por encima de cualquier otro fenómeno y objeto de estudio. La presencia de Roman Jakobson emerge en muchas ocasiones en los textos de ficción piglianos. Podríamos citar el célebre ejemplo de la carta que en Respiración... Emilio le envía a su tío Marcelo. Habla de las funciones del lenguaje analizadas por el gran lingüista ruso: la fática, la metalingüística, etc. ${ }^{262}$ Sin embargo, es fácil entrar por cualquier puerta lateral de la red literaria del autor argentino para reconocer la presencia del metalenguaje. En "Encuentro en Saint-Nazaire", las funciones del lenguaje van encaminadas a la preparación del acontecimiento fantástico, que tendrá lugar en el lenguaje mismo, mediante la función metalingüística. Cuando el personaje Ricardo Piglia encuentra en la Maison una fotocopia

\footnotetext{
${ }^{259}$ Ricardo Piglia, El último lector, op. cit., pp. 11-17.

${ }^{260}$ Ricardo Piglia, La ciudad ausente, op. cit., p. 109.

${ }^{261}$ La ciudad ausente, op. cit., p. 139.

${ }^{262}$ Respiración artificial, op. cit., pp. 33-35.
} 
(un doppelgänger más) de una hoja de un cuaderno de Stevensen, hay una especie de prolepsis narrativa que anticipa los siguientes sucesos. Lo que ahí se narra corresponde a un encuentro entre Stevensen y una mujer de origen esloveno: "Entonces, le dijo él, dígame algo en esloveno. Ella dijo en esloveno: Hoy es un día soleado" (p. 88). Al margen del metalenguaje presente en las palabras previas a las de la mujer, si se analiza a qué función del lenguaje corresponde su frase, podríamos afirmar que se trata de la función fática, ya que ella solo habla para mantener viva la comunicación, lo hace porque alguien más se lo pide, aunque presentimos que lo hace de mala gana. Por eso, ella responde así a otra petición de Stevensen: "La mayoría de los ingleses desprecian nuestra lengua" (p. 88). Esta oración puede ubicarse dentro de la función referencial, pues proporciona cierta información y especifica el contexto en el que se desarrolla, pero también corresponde a la función metalingüística, ya que la frase está dicha en esloveno y las palabras "nuestra lengua" indican que habla sobre el habla. Inclusive, ella no está segura de que Stevensen conozca su lengua y comprenda la oración. Por otra parte, esta frase vuelve a resaltar la posición de las lenguas y razas periféricas a la Europa occidental: es también una toma de posición política frente a las culturas colonialistas. Parece que el deseo de escuchar algo en esloveno es más un capricho exótico de Stevensen, pero el escritor, hijo de una polaca y un irlandés (¿un cruce entre la literatura de Gombrowicz y la de Joyce?), ha estado guiando a la mujer en lo que sería un experimento verbal, capaz de producir una obra de carácter fantástico. Después de las dos frases, pronunciadas por la mujer, Stevensen pide más, “cuénteme un cuento” (p. 88). Después de algunos minutos de silencio, la mujer dice: “¿Ve ese gato, ahí, en el césped?” (p. 88). El acontecimiento fantástico se ha producido: el relato, que está incompleto, es ambiguo porque no conocemos el contexto de la historia (solo hay un fragmento diminuto) y ni siquiera se sabe si verdaderamente existe un gato en el césped. 
Somos lectores de un texto que parece no dirigido a nosotros: pareciera que estamos obligados a aceptar. Es de notar que el empleo de las comillas, en la cita anterior, se produzca una sola vez: las dos frases que la precedieron iban sin entrecomillar, lo que le otorga un valor adicional, un énfasis que puede conectarse con el género fantástico del siglo XIX. Después de la última frase de la mujer, termina el texto de la fotocopia. Es probable que en este fragmento se condense el relato fantástico que lo encuadra, y que a su vez es encuadrado por el relato de una máquina, como en Las mil y una noches. Se ha pasado de lo metalingüístico y lo metaficcional a lo fantástico puro, a través de las libres formas del lenguaje.

El microrrelato de la mujer eslovena anticipa y simboliza todo el relato de la novela corta. Todo el texto ofrece múltiples cruces, referencias cruzadas situadas en forma de analepsis y prolepsis que rompen la linealidad. Parafraseando a Deleuze y Guattari, el texto es un rizoma que permite entradas y salidas desde cualquier sitio $^{263}$. El personaje Piglia ha podido comprobar que su paso por Saint-Nazaire no es azaroso ni ha sido decidido por él: Stevensen ha escrito y descrito sus acciones, que él sigue puntualmente. La repetición textual es otra variante del tema del doble. Lo que Piglia personaje narra al principio del relato pseudoautobiográfico, vuelve a aparecer al final, cuando Stevensen se ha ido y aquel encuentra sus escritos proféticos en la Maison y, más tarde, en la computadora del doble cuarto de hotel (con una puerta disimulada con un espejo que une la alcoba con el laboratorio) adonde se había mudado. Paso por paso, el personaje Piglia reconoce, incluso, sus propias llamadas, sus conversaciones y sus pensamientos que únicamente un narrador

263 “CCómo entrar en la obra de Kafka? Es un rizoma, una madriguera. El castillo tiene múltiples entradas, de las que no se conoce las leyes de uso y de distribución [...] Así pues, entraremos por cualquier extremo, ninguno es mejor que otro, ninguna entrada tiene prioridad, incluso si es casi un callejón sin salida, un angosto sendero [...]" Gilles Deleuze y Félix Guattari, op. cit., p. 11. 
omnisciente podría haber captado. Cada acción ejecutada es simétrica a la escrita, a la profetizada. Se invierte de este modo el proceso de escritura: en la línea de la literatura fantástica rioplatense, la realidad imita a la ficción, se borran las fronteras ${ }^{264}$.

El personaje Ricardo Piglia actúa como un autómata porque ejecuta las acciones que Stevensen escribe en su "ordenator" (p. 109): curiosa palabra que no sólo ofrece la acepción, traducida o en su lengua original, de ordenar los textos y las palabras; también se comprende en el sentido del modo imperativo, como el destino humano controlado por los dioses y anunciado en los oráculos. Stevensen ha descubierto el orden inverso del mundo a través de la palabra escrita y puede anticiparse a todo. La confesión previamente anunciada por Stevensen se comprueba cuando el narrador-personaje Piglia llega a la Maison y encuentra (no al azar, pues eso también ha sido planeado y escrito por Stephen) el Diario, donde lee lo que acababa de ocurrir días antes:

En las primeras anotaciones Stevensen se movía a ciegas. No conocía mi nombre. Me llamaba el argentino. O simplemente me llamaba Él. De a poco los borradores se iban haciendo más precisos. Stevensen escribió con increíble seguridad. Era una ventaja haber vivido en la misma casa donde yo estaba viviendo. Podía imaginar mis desplazamientos, mis hábitos. Lentamente empezó a anticipar mis movimientos. El Diario podía haber sido escrito por mí (pp. 106-107).

Esta idea de la duplicación y de que el autor es una creación de su personaje es de antemano una característica de la literatura fantástica argentina desde Borges, quien sugiere los nombres de algunos precursores clásicos en "Magias parciales del Quijote”, cuando algunos personajes de la novela hablan sobre Cervantes o ya han leído la primera parte, de

\footnotetext{
${ }^{264}$ Para Bratosevich, no solo se borran las fronteras entre realidad y ficción: también se anulan los géneros: “el discurso fantástico se 'traiciona' en invención fantástica. La ficción excede el punto final e incorpora la firma autoral a su predio: se relativizan las categorías de los géneros y los supuestos límites textuales" ( $o p$. cit., p. 19).
} 
1605. Borges entiende que en estos sucesos "Cervantes se complace en confundir lo objetivo y lo subjetivo, el mundo del lector y el mundo del libro"265.

Siguiendo esa desaparición de géneros que Bratosevich postula, cabe señalar que la nouvelle excede sus límites textuales: Piglia juega con los conceptos de realidad y ficción en la "Nota" final de Prisión perpetua:

\begin{abstract}
"Encuentro en Saint-Nazaire" fue escrito durante una estadía de tres meses en la Maison des écrivains et traducters de Saint Nazaire. Los extraños sucesos que ocurrieron en ese lugar no empañan el recuerdo de los bellos y brumosos días que viví en el Building y tampoco el agradecimiento a mis amigos de la Maison y en especial a su director, Christian Puskas, cuya exigente cordialidad estuvo siempre atemperada por un uso personal de la lengua francesa que lo tornaba al mismo tiempo generoso e incomprensible [...] Puskas trató de prevenirme sobre lo que me esperaba pero previsiblemente no lo comprendí. La noche en que llegué me recibió en la estación de trenes y en un idiolecto, que me sonó al principio como una declinación bretona del húngaro, me dijo (ahora lo sé) que no le diera mi confianza al huésped que había abandonado la casa la noche misma de mi llegada [...] ¿cómo podía yo adivinar lo que ese hombre, a quien veía por primera vez, trataba de decirme? (pp. 149-150)
\end{abstract}

Si la cita anterior permite establecer el cruce perfecto entre lo real y lo ficcional, los últimos renglones llevan a la exasperación esa intención de hacer de lo cotidiano un acontecimiento fantástico: "El relato que he escrito es un efecto de esa incomprensión y también un efecto

265 Jorge Luis Borges, "Magias parciales del Quijote", Otras inquisiciones, Alianza Editorial, Madrid, 1981, p. 53. En otro momento, también establece las confusiones entre lo real y lo imaginario: “¿Por qué nos inquieta que el mapa esté incluido en el mapa y las mil y una noches en el libro de Las mil y una noches? ¿Por qué nos inquieta que Don Quijote sea lector del Quijote y Hamlet espectador de Hamlet? Creo haber dado con la causa: tales inversiones sugieren que si los caracteres de una ficción pueden ser lectores o espectadores, nosotros, sus lectores o espectadores, podemos ser ficticios. En 1833, Carlyle observó que la historia universal es un infinito libro sagrado que todos los hombres escriben y leen y tratan de entender, y en el que también los escriben" (Ibid., p. 55.). Esta línea fantástica totalmente consciente de sí misma es en la que Piglia hace sus operaciones. Para González Álvarez, en "Encuentro en Sain-Nazaire”, el personaje Stevensen, inventado en la realidad por el escritor Ricardo Piglia, se encuentra en el mismo nivel que este cuando aparece en el texto como personaje: "El vértigo de la metaescritura (diario ofrecido en abismo) y de la metalectura, con un narrador obnibulado que lee sus propias vivencias en ese oráculo, evidencian que ambos son creadores y criaturas en igual medida y la nouvelle exhibe en consecuencia un perspectivismo muy notorio" (José Manuel González Álvarez, op. cit., p. 135.) La referencia de Borges a Carlyle y a la ubicación de autores, lectores y personajes, queda ilustrada en la nouvelle pigliana. 
de la telaraña verbal que Stevensen tejió a mi alrededor” (p. 150). Por un lado, Piglia sostiene que se trata de un relato, de una narración ficcionalizada; por otro, vuelve a darle vida y poder a Stevensen sobre él, fuera del relato. La "Nota" que por lo general explica de manera clara algún aspecto del volumen, funciona, en este caso, para continuar con ese "efecto" de confusión entre los seres reales y los imaginarios. En esa red de relatos donde destaca el tema del doble, Jorge Carrión afirma:

La "Nota" que cierra la última edición de Prisión perpetua no tiene fecha. Fue suprimida en la edición del año 2000 en Lengua de Trapo. Aparecía, en cambio, en la de 1998 en Seix Barral Argentina. El cotejo de las dos versiones es revelador. Entre otros muchos cambios, el director de la Maison des Écrivains et Traducteurs de Saint-Nazaire, pasa de llamarse Christian Bouthemy a ser Christian Puskas. Es decir, pasa de ser el director real del centro a convertirse en un personaje de ficción, con el apellido del famoso jugador de fútbol húngaro. En otras palabras: pasa de ser coherente con el mundo real (histórico) a ser coherente con el mundo ficcional (ahistórico) ${ }^{266}$.

En un giro hiperbólico que rompe los límites de géneros, Piglia exhibe sus procedimientos metaficcionales para insertarse en la literatura fantástica rioplatense, pero en "Encuentro en Saint-Nazaire" va más allá, ya que se introduce, inclusive, en la tradición autorreferencial francesa. Pareciera que su nouvelle, escrita durante el tiempo que duró su estancia en SaintNazaire, fuera un homenaje a André Gide (precursor del relato especular en su país) y, más cercano a nuestros días, al Nouveau Roman, con Michel Butor como uno de sus principales representantes. Sin embargo, es necesario aclarar que ese supuesto homenaje sería irrelevante si no desviamos la lectura de lo inmanentista (en Piglia, ningún procedimiento literario es gratuito: cumple una función que por lo general le otorga un sentido social) a su función política: en el desdoblamiento de los personajes, "Diario de un loco" extiende la

\footnotetext{
${ }^{266}$ Jorge Carrión, op. cit., p. 16.
} 
presencia de Maggie a la resistencia social: a veces es nombrada como Erika, sobre todo cuando se revela su carácter revolucionario ${ }^{267}$. En este sentido, el nombre Maggie, de terminación anglosajona, nos remite a otro personaje pigliano revolucionario: Maggi.

El relato autorreferencial es elevado, probablemente, a una categoría hiperbólica. A partir de la lectura de El relato especular de Lucien Dällenbach y su asociación con la novela breve de Piglia pueden crearse nuevas líneas de investigación. Las referencias a París y otros sitios de Francia son constantes en el texto que nos ocupa. Por ejemplo, Maggie piensa en dejar Inglaterra, establecerse en la capital francesa y aceptar un puesto de investigadora en Princeton (p. 129). Su vida es una referencia cruzada con el autor Ricardo Piglia, quien viene de Princeton y Argentina ${ }^{268}$ para instalarse en Saint-Nazaire, con una escala en París, donde tomará el tren. En el trayecto París-Saint-Nazaire, lee los Carnets de travail de Flaubert, en un triple gesto autorreferencial: por un lado, las cartas se refieren al trabajo literario, como en un laboratorio; por otro, la mención al autor de Madame Bovary sitúa la nouvelle pigliana en la tradición lectora del siglo XIX y en el bovarismo, concepto en el que el lector (real o imaginario) repite en la práctica las acciones que va leyendo; finalmente, se trata de un signo que Stevensen introduce en la conversación para que,

\footnotetext{
${ }^{267}$ La recepción actual del Nouveau Roman refleja que ese movimiento narrativo autorreferencial poco a poco ha ido automatizándose y, por lo tanto, ha perdido su fuerza y originalidad. Un escritor contemporáneo de Piglia, Enrique Vila-Matas, parodia y ridiculiza un poco a los escritores franceses de esa ola (sin dejar de reconocer su importancia en la historia de la literatura occidental) en Bartleby y compañía, a propósito de una amiga del narrador (dedicado a registrar los casos del síndrome de Bartleby, o sea de los escritores que súbitamente enmudecen y nunca vuelven a escribir) que, una vez instalada en París para convertirse en la gran novelista, queda bloqueada por el estilo. Una muestra: "Un día, ella decidió retomar Le cafard. El barco no parecía progresar en ninguna dirección, así comenzó su nuevo intento de ser novelista, pero lo comenzó con un lastre del que era consciente: el de la obsesión robbe-grilletiana por anular el tiempo, o por detenerse más de lo necesario en lo trivial" (Enrique Vila-Matas, Bartleby y compañía, Anagrama, Barcelona, 2005 (Narrativas hispánicas, 279), p. 49).

${ }^{268}$ En 1987 residió durante algunos meses en la Universidad de Princeton como "senior fellow del Council of the Humanities", un año antes de llegar a la Maison de Saint-Nazaire. Cfr. "Cronología" en Jorge Fornet (ed.), Ricardo Piglia, op. cit., pp. 278-279.
} 
después, el personaje Piglia descubra que ha leído a Flaubert por decisión del escritor demente.

Dällenbach analiza la literatura de Gide para identificar los momentos autorreferenciales en su obra y establecer una teoría literaria al respecto. Por nuestra parte, sus hallazgos pueden ser leídos como un acercamiento a la literatura especular en Piglia, tomando como punto de comparación algunas obras de Gide, como La tentative amoureuse, que ofrecería una lectura intertextual si se le relaciona con "Encuentro en Saint-Nazaire". En esa obra, el autor controla a su personaje al hacer un "experimento científico"269. De manera inversa, en la nouvelle pigliana, el que imaginamos como autor, Ricardo Piglia, se transforma, en ese espacio pseudoautobiográfico, en la víctima del que sería, en este sentido (y sin dejar de tomar en cuenta la "Nota" de Prisión perpetua) el verdadero autor: Stephen Stevensen.

Los procedimientos metaficcionales y metalingüísticos que Piglia lleva a cabo pueden sugerirnos la idea de una práctica intertextual que establece relaciones con una tradición de la literatura francesa. En este sentido, es posible pensar en una posición estética asumida por Piglia al momento de crear una obra autorreferencial que lo conecta, implícitamente, con algunos escritores galos. Para Dällenbach, Los monederos falsos de Gide plantea su alejamiento del realismo decimonónico. En el análisis que hace de una cita deformada que Gide tomó del Stendhal de Rojo y negro, "Novela es el espejo que uno pasea a lo largo del camino", para reescribirla de tal modo que el diario del protagonista, Édouard, sea "el espejo que paseo conmigo", Gide le otorga a las apreciaciones de su personaje "un punto de vista de la realidad tan parcial como el de los restantes personajes" ${ }^{270}$, lo que hace relativa

\footnotetext{
${ }^{269}$ Lucien Dällenbach, op. cit., p. 29.

${ }^{270}$ Ibid., p. 44.
} 
toda visión que intenta hacer de la realidad una descripción objetiva. Simultáneamente, podemos apuntar también que en estas citas que Dällenbach recupera hay también un nexo intertextual y de cruce de géneros que el propio Piglia compartiría y que él ha realizado, por su parte, en muchas ocasiones: la deformación de una cita tiene una clara intención poética: del realismo se pasa al subjetivismo literario; de la novela, género tan cultivado en el realismo, se produce un salto a una forma mucho más dúctil porque puede realizar combinaciones más atrevidas: el diario. No resulta forzada, entonces, la presencia de esas citas en el marco del análisis de un supuesto texto autobiográfico ni del diario ficcional que encierra la literatura oracular de Stevensen, en la puesta en abismo que la estructura narrativa refleja. Las relaciones entre novela y diario en Los monederos falsos y "Encuentro en Saint-Nazaire" son tales que, en ambos casos, los lectores asisten a una puesta en abismo donde se cruza lo autobiográfico con lo ficcional: en la obra de Gide, el personaje Édouard lleva un diario; en la nouvelle pigliana, el discurso autobiográfico se transforma en una narración fantástica que comprueba tal característica en el momento de la lectura del diario de Stevensen, además de que la segunda parte de la novela, "Diario de un loco", ofrece las reflexiones de este personaje a partir de las numerosas entradas de su Diccionario personal $^{271}$. Como Enrique Ossorio en Respiración artificial, la escritura (y lectura) del

\footnotetext{
${ }^{271}$ La forma del diccionario, como un género discursivo híbrido que sirve para ofrecer nuevas historias, microrrelatos, cuentos y breves ensayos en las definiciones que ofrece, ya había sido utilizada por Piglia en dos momentos: la primera en su intervención, junto con su círculo de estudio, en Conversaciones imposibles con Macedonio Fernández, volumen que transcribe la participación del escritor argentino en las jornadas de homenaje a Macedonio Fernández en 1997. Después de fijar la postura de Macedonio, en el contexto de una nueva novela de vanguardia que cuestionara la "realidad" oficial y se deslindara del realismo literario de los primeros años del siglo XX, el Colectivo 12, un grupo de alumnos de Piglia, explica algunos aspectos del Museo de la novela de la Eterna a partir del formato del diccionario. Se enlistan alfabéticamente y se definen algunas palabras en el contexto de la obra de Macedonio. Tal ejercicio culminará, años después, en el Diccionario de la novela de Macedonio Fernández. La relación intratextual con el "Diario de un loco" tiene como nexo el genotexto La ciudad ausente. Cfr. Ricardo Piglia y Colectivo 12, ["Sobre Macedonio Fernández"], transcripción de Julia Rodríguez, en Mónica Bueno (comp.), Conversaciones imposibles con Macedonio Fernández, Corregidor, Buenos Aires, 2001, pp. 27-55, y Diccionario de la novela de Macedonio Fernández, (ed. de Ricardo Piglia), FCE, Buenos Aires, 2000 (Tezontle).
} 
diario íntimo establece la conexión entre presente, pasado y futuro. Si un diario es leído siempre en retrospectiva porque conserva las reflexiones pasadas, en la poética de Piglia este género discursivo permite conocer el futuro para prevenir nuevas catástrofes:

\begin{abstract}
Es menester, por consiguiente, que este espejo [el diario de Édouard] se limite a reflejar "el interior de la estancia en que se desarrolla la escena pintada". Espejo-trampa, como el de los pintores, "añade información" al relato, interceptando aquello que rebasa su campo de visión. Cabe esperar, por supuesto, que tal forma de espionaje vaya en beneficio de la exposición: llevando a cabo una sutil vuelta atrás, el "Diario" logra unir el pasado con el presente ${ }^{272}$.
\end{abstract}

En los diarios de Ossorio y Stevensen se escribe hacia el futuro ${ }^{273}$. Si asociamos esto con la cita anterior de Dällenbach y su ilustración con la pintura de "espejo-trampa", principalmente la de los pintores flamencos del siglo XV, como Jan Van Eyck (la escena pintada dentro de la propia escena, como en El matrimonio Arnolfini), puede interpretarse que la literatura es un espejo que no solamente capta sus propios signos, a propósito de su forma especular, sino también otros que, de modo tangencial, lateral y marginal (como en los espejos cóncavos de la pintura flamenca), aparecen sugeridos, sutilmente ubicados para indicar la presencia de un mensaje secreto, no dicho de manera verbal que, en el caso de la literatura, sirven para trascender la censura política ${ }^{274}$.

\footnotetext{
${ }^{272}$ Lucien Dällenbach, op. cit., pp. 44-45.

${ }^{273} \mathrm{La}$ escritura profética del diario siempre posee una relación significativa con el augurio, la predicción mediante el estudio del vuelo de las aves. Nuevo ejemplo, ahora del diario de Enrique Ossorio: "Hablo del tema de mi relato con Lisette. Ella me dice: ¿Pondrás tú ahí una mujer que como yo sabe leer el futuro en el vuelo de los pájaros nocturnos? Pondré, le digo, quizás, en mi relato, a una adivina, una mujer que, como tú, sepa mirar lo que nadie puede ver" (Respiración artificial, op. cit., p. 80). El empleo de la autorreferencialidad no solo se percibe en la estructura del diario y en sus posibilidades metalingüísticas a la hora de escribir sobre el diario. La respuesta que Ossorio le da a Lisette es una respuesta espejo, su doble. Cabe señalar una última observación al margen: en las mujeres piglianas, la predicción siempre es oral; en los hombres, siempre se asocia con la escritura (principalmente del diario personal que tiende a hacerse público). Sólo la máquina de narrar, al combinar tradición y tecnología, es capaz de conciliar las oposiciones: oralidadescritura, femenino-masculino, fantástico-realismo, estética-política.

${ }^{274}$ Esta reflexión probablemente contribuya a la interpretación del título de la primera parte de Respiración artificial: "Si yo mismo fuera el invierno sombrío", obra imaginaria que el narrador Emilio Renzi atribuye a
} 
Espejo de sí mismo, el relato "Encuentro en Saint-Nazaire" ofrece una historia notoriamente autorreferencial: "El relato doble o relato en espejo (donde queda comprometida la relación autor-autor, autor-lector y perseguidor-perseguido) articula no sólo el estrato anecdótico,275, ya que es un intento de indicar el modo en que Piglia quiere ser leído, a partir del concepto de "repetición-escritura"276 que Bratosevich encuentra. Las abundantes referencias intertextuales también forman parte de aquellos signos oraculares que hay que descifrar. Bratosevich recuerda la presencia de Walter Benjamin en el texto, a partir de un artículo escritor por Stevensen que "Piglia" encuentra en la Maison. El texto alude a "La obra de arte en la época de su reproductibilidad técnica" y a Molohy-Nagy, el fotógrafo que Benjamin cita "en función de las reflexiones [...] a propósito de la reproductibilidad como fenómeno contemporáneo"277. Tenemos, nuevamente, que la duplicación, las referencias intertextuales y el procedimiento autorreferencial pueden ser leídos como parte de la máquina de lo fantástico en Piglia, no sin dejar de lado la función social que complementa la actividad literaria del escritor argentino. La presencia de Benjamin, una vez más, funciona como un referente de la práctica estética vanguardista unida al proyecto revolucionario. Si en Respiración artificial la presencia del filósofo alemán es implícita, pero nítida al mismo tiempo, en la nouvelle que nos ocupa su mención directa permite establecer un nuevo cruce con lo fantástico mediante las formas metaficcionales. Como se vio en el primer capítulo, un estudiante, residente en Estados Unidos, lee una novela de Saul Bellow, un cuento de Donald Barthelme y una novela

\footnotetext{
Frans Hals, (1585-1666) heredero de la antigua pintura flamenca. La frase podría adjudicarse a Enrique Ossorio debido a su ambigüedad política, a los ojos de sus compatriotas. Además, como la antigua pintura flamenca, su diario permitiría ver otros aspectos que nadie más alcanza a mirar. De ahí también su condición profética que lo pone muy cerca de los grandes visionarios del siglo XX: Kafka en Europa, Arlt en Argentina. Para este tema, cfr. Jorge Fornet, El escritor y la tradición, op. cit., pp. 65-66.

${ }^{275}$ Nicolás Bratosevich, op. cit., p. 20.

${ }^{276}$ Ibid., p. 21.

${ }^{277}$ Ibidem.
} 
“erróneamente” atribuida a Grace Paley pero que en realidad es autoría de Iris Murdoch. En los tres textos, la lectura es anticipo de acciones futuras. La literatura se convierte en un espacio oracular donde los signos deben ser interpretados de manera exacta, con la finalidad de poder adelantarse a los sucesos históricos trágicos. Como un complemento gemelo inverso (siniestro o izquierdo) de aquel pasaje, "Encuentro en Saint-Nazaire" anticipa las acciones futuras mediante la escritura, calificada por Bratosevich como fantástica-oracular. En el intento de convencer a "Piglia" de su descubrimiento profético, Stevensen le da a leer algunas notas de su diario. En un fragmento, Stevensen remite a la parte previa de su escritura oracular: en un vagón de tren, conoce a una mujer rubia con la que brevemente entabla conversación. Poco después, continúa la lectura que estaba realizando, hasta que llega a su destino y pierde de vista a la mujer. Este suceso cotidiano le sirve para empezar su experimento:

Una situación trivial. Alguien conocido circunstancialmente en un viaje en tren. Una mujer cualquiera. Rubia, ojos lívidos, casi una desconocida. Podía empezar con ella. Tomarla como objeto de mi investigación. Di algunas vueltas por la casa para tranquilizarme. En el aire, por la ventana, se oía el sonido siniestro, metálico, del viento que venía del Loire. Me senté a la mesa, abrí el cuaderno y empecé a escribir.

27 de marzo. Entro en el bar que está frente al mercado. Dos hombres discuten en la barra. Busco un lugar cerca de la puerta y pido un rouge. Hay una extraña quietud, como si todos en todos lados se hubieran quedado callados. En medio del silencio se abre la puerta y entra la muchacha rubia con la que viajé en el tren desde París. Mira hacia un costado, sonríe, no me reconoce. En el reloj son las cinco menos diez (pp. 102-103).

Stevensen interrumpe la escritura y, una hora después, sale para comprobar su experimento: 
Cuando entré en el bar eran las cinco menos cuarto. Busqué una mesa cerca de la ventana y pedí un rouge. Me pareció que afuera había empezado a lloviznar. Dos hombres discutían sentados en la barra. Los ruidos se fueron apagando, como si todos se hubieran quedado callados. La puerta de vidrio se abrió y la muchacha rubia con la que viajé en el tren desde París entró en el bar. Miró hacia un costado, sonrió, no me reconoció. En el reloj, eran la cinco menos diez (p. 103).

Las citas anteriores son un anticipo de lo que el personaje Piglia leerá en el diario de Stevensen, a solas. La escena duplicada, similar a la escenas de lectura reproducidas de Respiración artificial sienta su base poética en la lectura y la escritura proféticas: son una metáfora de la creación literaria: el escritor no reproduce con fidelidad lo que ve de la realidad; más bien, encuentra, en la realidad deformada por el Estado, los signos que le ayudarán a reconstruir la visión del mundo, que como intenta ser organizada, disciplinada y oficial, debe ser vista, ahora, como un espejo deformante que escape a la mirada que intenta que todo sea homogéneo. No es casual que parte de la historia comience en el vagón de un tren, símbolo de la lectura en el siglo XIX, según Piglia. La lectura placentera en el ferrocarril (como la que lleva a cabo el personaje Piglia, cuando lee los Carnets de travail de Flaubert, en un claro signo de aproximación a la lectora Madame Bovary) excede el espacio de la ficción y se instala en la "realidad"278. La literatura fantástica anula la realidad creada por el autoritarismo y señala el modo de la resistencia: salir de lo convencional para producir una obra de ruptura estética y social. El propio personaje Piglia descree de la historia de Stevensen y lo considera un loco, pero al final, al re-comenzar el acto de leer, lo

\footnotetext{
${ }^{278}$ En un ensayo sobre los lectores, Piglia recuerda la función del ferrocarril en el siglo XIX como espacio cotidiano de lectura y ejemplifica con Anna Karenina, Emma Bovary y, como eco de esa actividad intelectual y lúdica, con Dahlman y el protagonista de "Continuidad de los parques". De la novela de Flaubert proviene, justamente, el término de "bovarismo", tan frecuente en los textos piglianos: "Emma, don Quijote y Eric Lönnrot actúan como lo que leyeron en los libros, representan un personaje imaginario, actúan los efectos de la lectura". Cfr. "La linterna de Anna Karenina, El último lector, op. cit., pp. 139-164. La cita anterior corresponde a la página 161 .
} 
sobrecoge la certeza de la realidad e, incluso, se reconoce como un personaje de fícción, no sólo por tener la convicción de ser un autómata al servicio de los experimentos de Stephen, sino por lo que él mismo había narrado su salida de Argentina y su estancia en Francia, que vuelve a identificar en una página de Stevensen, escrita una semana antes de esos acontecimientos. Una vez que ha huido de este, abandonándolo en su doble cuarto de hotel, "Piglia" llega a la Maison y encuentra un sobre con la "serie de papeles que me estaban destinados" (p. 106), en un claro gesto y estilo borgianos. Ahí, lee los sucesos que vivió en la noche de su llegada a Saint-Nazaire:

La primera noche que pasa en Saint-Nazaire habla por teléfono con una mujer. Le dice que está en Austria, que se vuelve a Buenos Aires, que la ha estado esperando en París, en el café Cluny, tres días seguidos. La mujer se ríe, no puede creer que él se haya ido a Austria. Es un lugar infecto, le dice, sólo poblado de canallas y antiguos nazis. Hay que vivir en Holanda o en Túnez, dice la mujer. Después lo cita en el café Cluny. Pero no sé si podré ir, le dice ahora. Como sabes estoy loca. Encerrada en una prisión psiquiátrica en la Selva Negra. Soy la lejana sobrina de Nietzsche. La última sobrina argentina de Nietzsche. Me llamo Lucía Nietzsche. Él trata de calmarla. La mujer le pregunta cuánto tiempo se va a quedar en Austria. Él le contesta con evasivas. Después lo llamo por teléfono, lo invito a almorzar (pp. 107-108).

Resulta evidente que en este texto, Piglia no solo aparece como personaje para anular cualquier frontera entre realidad y ficción, él mismo ha sido absorbido por su máquina de narrar de La ciudad ausente. La presencia de Lucía Nietzsche, personaje de "El fluir de la vida" (la segunda parte del relato-espejo "Prisión perpetua", y que a su vez se conecta con otro personaje-espejo-loco: Lucía Joyce de La ciudad ausente), así como la "Nota" final del volumen, que confirma la existencia de Stevensen, así lo sugieren. Esa Lucía Nietzsche es 
la misma que el Pájaro Artigas, en "El fluir de la vida", observa a través del espejo, cuando besa a su padre ${ }^{279}$.

Este curioso procedimiento formal, donde el autor se asume como personaje de su propia ficción, está muy cerca del concepto de metalepsis. Según Gérard Genette, quien se basa en Fontanier para su definición, la metalepsis es una figura retórica que consiste en "transformar a los poetas en héroes de las hazañas que celebran [o en] representarlas como si ellos mismos causaran los efectos que pintan o cantan"280. Además, la metalepsis se produce "cuando un autor es representado o se representa como alguien que produce por sí mismo aquello que, en el fondo, sólo relata o describe" ${ }^{\text {281 }}$. De acuerdo con esta visión clásica de la figura, el autor se ubica dentro de lo que narra o describe. Tomando en cuenta, por otro lado, que el estructuralismo y la narratología han convenido en separar la noción de autor de la de narrador, en "Encuentro en Saint-Nazaire" dicha separación es difícil de realizar, ya que se trata de un texto conformado por el cruce de formas autobiográficas y novelísticas (el misterio y el viaje son características de la nouvelle) que dialogan con otros géneros más: el diario y el diccionario, en los terrenos del género fantástico. Por un lado, la presencia de Borges es absoluta y omnipresente (Genette recuerda que muchos cuentos de este comienzan con una forma metaléptica, como "La forma de la espada"282; además, la presencia de Borges también es evidente y omnipresente en el volumen del teórico francés: termina con el fragmento de la cita tantas veces repetida de "Magias parciales del Quijote"283, también repetido aquí); por otro, Piglia se propone romper los modos tradicionales de los géneros $\mathrm{y}$, en un giro renovador de la lectura de

\footnotetext{
${ }^{279}$ Para el análisis de este cuento (desde la intertextualidad y la metaficción en la poética pigliana) cfr. el tercer capítulo de De la crítica a la ficción..., op. cit., pp. 74-98.

${ }^{280}$ Gérard Genette, Metalepsis, op. cit., p. 10.

${ }^{281}$ Ibid., pp. 10-11.

${ }^{282}$ Ibid., p. 133.

${ }^{283}$ Ibid., p. 155.
} 
estos, crea una obra con múltiples cruces que rompen las estructuras y divisiones tradicionales de categorías narrativas, géneros literarios y conceptos filosóficos ${ }^{284}$.

No es azarosa, entonces, la presencia de Enrique Vila-Matas en estas páginas. En la línea del escritor argentino, el autor de El mal de Montano recupera en esa obra una frase fundamental para nuestro tema de estudio: “Quizá la literatura sea eso: inventar otra vida que bien pudiera ser la nuestra, inventar un doble. Ricardo Piglia dice que recordar con una memoria extraña es una variante del doble, pero es también una metáfora perfecta de la experiencia literaria" ${ }^{, 285}$.

De manera definitiva, puede afirmarse que las ideas de Borges sobre la memoria están presentes, ocultas detrás de la cita de Vila-Matas y de "Encuentro en Saint-Nazaire". La cita que hace el autor español está tomada de "El último cuento de Borges", de Formas breves $^{286}$. En ese texto ensayístico, que no descarta su relación con el cuento y otros modos de expresión, Piglia interpreta "La memoria de Shakespeare" en el ámbito de la literatura fantástica, lo que permite establecer su relación con La ciudad ausente y "Encuentro en Saint-Nazaire": "Los grandes relatos de Borges giran sobre la incertidumbre del recuerdo personal, sobre la vida perdida y la experiencia artificial. La clave de este universo

\footnotetext{
284 Otro punto de contacto con Gide: Dällenbach encuentra que en Los monederos falsos se produce una confusión de autores "introduciéndonos en una espacio ambidextro donde el principio de identidad se ve incesantemente atacado" (op. cit., p. 45).

${ }^{285}$ Enrique Vila-Matas, El mal de Montano, Anagrama, Barcelona, 2007 (Compactos, 436), p. 16. En los siguientes párrafos, el escritor español divaga sobre el tema del doble, estableciendo, de paso, la idea del doble del doble y aterrizando en un texto ad hoc: "El oscuro hermano gemelo" de Sergio Pitol, que es a su vez una recreación del tema del doble desarrollado por Vila-Matas. Cabe señalar que, tanto en "Encuentro..." como en la obra citada de Vila-Matas y en el relato de Pitol, que aparece en la obra miscelánea El arte de la fuga (Era/Editores independientes, México, 2007), el ejercicio literario cabalga entre la autobiografía y la ficción. En esta línea renovadora de las letras actuales, José Manuel González incluye, además de los tres autores mencionados, a Roberto Bolaño. Todos ellos "comparecen ante el lector acaso como los representantes máximos dentro del ámbito hispánico de esa estimulante tendencia de la narrativa contemporánea a la falsa autobiografía, al escrutinio de diarios, a las escrituras fronterizas y a los simulacros ensayísticos-ficcionales" (José Manuel González, op. cit., p. 42). Naturalmente, el proceso de cruce de géneros en Piglia está estrechamente vinculado con su poética y su lectura de la tradición literaria.

${ }^{286}$ Ricardo Piglia, "El último cuento de Borges", Formas breves, op. cit., p. 53. Lo único distinto es la frase "variante del doble": en el original, puede leerse: "variante del tema del doble".
} 
paranoico no es la amnesia y el olvido, sino la manipulación de la memoria y de la identidad"287. Más que comentar el texto de Borges sobre la herencia que recibe un escritor de la memoria de Shakespeare, Piglia hace empleo del cuento para apoyar una de sus ideas de la conspiración: los medios masivos y el Estado han impuesto un modo de comprender la realidad. "Cirugía psíquica de extirpación” de Macedonio es, como lo recuerda María Antonieta Pereira, un antecesor directo en la genealogía literaria de La ciudad ausente ${ }^{288}$. El texto de Borges es un pretexto para discurrir sobre la presencia de los mass media en la vida cotidiana: "La cultura de masas (o mejor sería decir la política de masas) ha sido vista con toda claridad por Borges como una máquina de producir recuerdos falsos y experiencias impersonales. Todos sienten lo mismo y recuerdan lo mismo y lo que sienten y lo que recuerdan no es lo que han vivido" 289 . Como si fuera un argumento para la ciencia ficción o una ucronía (dos ejemplos: Blade Runner y El hombre en el castillo, respectivamente), la instauración de una memoria falsa puede producir un efecto en los receptores de manera semejante a aquellos personajes de Manuel Puig que no pueden escapar de sus jaulas ideológicas e intentan imitar las acciones de sus estrellas de cine y $\operatorname{radio}^{290}$.

En "Encuentro en Saint-Nazaire”, el personaje Piglia está controlado por la escritura de[1] otro, de su doble literario (que a su vez se desdobla en su hermana Maggie y quien a su vez tiene una vida parecida en algunos aspectos al autor Piglia y al personaje Renzi: trabajará en Princeton, es lingüista y posee una conciencia social que refleja su perfil solidario). La entrada lateral a la red de referencias y citas por la que hemos penetrado

\footnotetext{
${ }^{287}$ Ibid., p. 51.

${ }^{288}$ María Antonieta Pereira, op. cit., pp. 128-132.

${ }^{289}$ Ricardo Piglia, Formas breves, op. cit., p. 52.

${ }^{290}$ Cfr. uno de los primeros textos críticos de Piglia, dedicado a la primera novela de Puig: "Clase media: cuerpo y destino (Una lectura de La traición de Rita Hayworth de Manuel Puig)", Actual. Revista de la Universidad de los Andes (Mérida), año II, núm. 6, enero-abril de 1970, s / n pp.
} 
azarosamente comenzó en El mal de Montano y nos llevó hasta "El último cuento de Borges". Pero ese texto es una escala más en la trama de Piglia: la última parte establece nuevos nexos con "El Aleph": por una parte, al principio del cuento, el personaje Borges (el autor se ubica dentro del relato: otro ejemplo de metalepsis) reflexiona sobre la fugacidad de la vida y la frivolidad del mundo, impuesta por los medios, a partir de la muerte de su amada Beatriz Viterbo: "noté que las carteleras de fierro de la Plaza Constitución habían renovado no sé qué aviso de cigarrillos rubios; el hecho me dolió, pues comprendí que el incesante y vasto universo ya se apartaba de ella y que ese cambio era el primero de una serie infinita" ${ }^{, 291}$; por otra, Piglia deja de lado el discurso ensayístico y, mediante el empleo de la enumeración, de clásica línea borgiana, evoca e invoca, a la manera del final de "El Aleph", distintos cuentos de Borges, como "El sur", "Biografía de Tadeo Isidoro Cruz", “Historia del guerrero y de la cautiva", etc. ${ }^{292}$ El acto de leer también funciona como una memoria falsa ${ }^{293}$. Pero lo sorprendente de este relato es, nuevamente, la alusión al tema del doble, en un párrafo narrativo que nos remite, nuevamente, a "Encuentro en Saint-Nazaire": "La tradición literaria tiene la estructura de un sueño en el que se reciben los recuerdos de un poeta muerto. Podemos imaginar a alguien que en el futuro (en una pieza de hotel, en Londres) comienza imprevistamente a ser visitado por los recuerdos de un oscuro escritor sudamericano al que apenas conoce"294. Sin lugar a dudas, este fragmento es un anticipo del pequeño Aleph que Piglia confeccionará al final de su ensayo: el oscuro escritor

\footnotetext{
${ }^{291}$ Jorge Luis Borges, El Aleph, Alianza Editorial, Madrid, 1999, p. 175.

292 Ricardo Piglia, Formas breves, op. cit., p. 54.

${ }^{293}$ En un giro hiperbólico que representa artísticamente lo que había afirmado bajo la forma prosaica del ensayo, Piglia cambia el libro que Dahlman ha estado leyendo mientras delira; si el narrador de "El sur" afirma que se trata de Las mil y una noches (y que revela por supuesto el carácter metaficcional del relato), en "El último cuento de Borges" se trata de la Comedia de Dante (Ibidem). ¿Olvido involuntario del autor? ¿Instalación de una memoria falsa? En El último lector, al mencionarse este cuento, el libro que el protagonista lee es el correcto -el que se recuerda "acertadamente" -: Las mil y una noches (op. cit., p. 30).

${ }^{294}$ Ricardo Piglia, Formas breves, op. cit., p. 53.
} 
sudamericano no es Borges, sino aquel, al ser imaginado por Stevensen en la habitación de hotel en Londres (adonde huyó para no darle explicaciones al personaje Piglia, para después perderse en la red de la ciudad-texto, como Junior en La ciudad ausente): doble desplazamiento de la tradición literaria: Borges, autor argentino, imagina que a un biógrafo alemán le es dada la memoria del autor de Hamlet en una pieza de hotel en Londres $^{295}$; Piglia inventa a un escritor británico que juega con él y lo hace su esclavo; lo imagina por las habitaciones de la Maison y, después, en un hotel de Inglaterra. Piglia ha recibido la memoria de Borges, pero también la de Stevenson y Joyce. Con los ojos de Piglia, no sólo vemos escenas de los cuentos de Borges, sino también a Macedonio Fernández y algunos pasajes del Martín Fierro, quizá pasados por la mirada de Borges, como "Biografía de Tadeo..." Finalmente, si la memoria falsa se encuentra en el debate "sobre la propiedad literaria"296 y Piglia ha recuperado y se ha apropiado de fragmentos célebres y marginales de la tradición literaria argentina, podría afirmarse que, en un sentido inverso, Stevensen ya no es un personaje de Piglia, sino de la literatura y la tradición: "La práctica arcaica y solitaria de la literatura es la réplica (sería mejor decir el universo paralelo) que Borges erige para olvidar el horror de lo real" ${ }^{\not 297}$. Probablemente, en esta cita se condensen lo fantástico y la función social de la creación literaria.

\footnotetext{
295 Jorge Luis Borges, La memoria de Shakespeare, op. cit.

${ }^{296}$ José Manuel González Álvarez, op. cit., p. 55.

${ }^{297}$ Ricardo Piglia, Formas breves, op. cit., p. 52.
} 


\section{CONCLUSIONES. LA LITERATURA DESPUÉS DE PIGLIA}

Ser escritor en la Argentina supone un reto crucial después de la literatura de Borges. Las generaciones posteriores han intentado diversos modos de expresión en el rechazo, la aceptación, la ironía y la toma de distancia con el autor de El Aleph. Sin embargo, su sombra también flota sobre el panorama rioplatense, que también alcanza a la literatura uruguaya. Si en "Un cadáver sobre la ciudad" Piglia imagina el féretro que transporta a Arlt flotando en las calles de Buenos Aires, insepulto -y vivo, en más de un sentido- y tan ancho que no cabe en el panorama contemporáneo, es por su condición marginal (sobre todo fuera de la Argentina). En cambio, la sombra de Borges, aceptada como la más influyente y decisiva en cuanto a sus recursos formales, extiende sus dominios sobre una gran parte de los procedimientos literarios que los escritores argentinos, desde Marechal, Bioy Casares y Cortázar, pasando por Saer, Piglia y Puig, y llegando hasta Alan Pauls y Rodrigo Fresán, han contribuido a su renovación y vitalización, produciendo nuevos niveles de significación en sus poéticas. Independientemente de la ideología asumida frente a la obra y la vida de Borges, todos los escritores argentinos se preguntan hasta dónde llega la influencia del gran maestro.

Sin embargo, en el diálogo que la literatura argentina establece con uno de sus grandes renovadores, existe la necesidad de salir de Borges para ingresar en las poéticas evidentemente más críticas con el sistema político capitalista y con modos de expresión menos cerrados, menos eruditos, que mantienen una mayor cercanía con la ciudad, incluyendo sus márgenes: "Arlt nos salvó de Borges", afirma Piglia. Su labor poética, desarrollada a lo largo de más de cuatro décadas (sin contar con el diario escrito desde los dieciséis años, o sea, desde 1957), ha buscado un contrapeso a la influencia de Borges y lo 
ha encontrado en esas figuras marginales y subversivas que cuestionan de inmediato, con las primeras ediciones de sus obras o con actos de retardamiento voluntario como un modo de oponerse a las leyes comerciales de las editoriales, esa realidad inventada por los aparatos estatales y sus dispositivos mediáticos. De paso, Piglia contribuye a una constante revisión de la tradición literaria, colocando en el centro a los escritores marginados en las décadas anteriores y cuestionando a los escritores oficiales, de ciertos indicios antisociales, como Leopoldo Lugones o Manuel Mujica Lainez. Las figuras de Arlt, Macedonio (“el próximo siglo será macedoniano”, en aumento ante la decreciente ola borgiana de nuestro tiempo contemporáneo, de acuerdo con Piglia), Onetti, Marechal, Puig o Saer (quien compartió con el autor de Nombre falso su oposición a esas prácticas literarias que degeneraron en un afán menos estético que comercial, como en el caso de varios integrantes del llamado Boom) llevan consigo un signo dual que expresa un significante de ruptura, promotor de una literatura de vanguardia que está en busca de sus lectores de vanguardia, y un significado que tiene su base social en la búsqueda de una realidad que, mediante sus recursos artísticos, confronte y encare las prácticas de los representantes de la ley. Por eso, una y otra vez, Piglia insiste en el gesto vanguardista y político de Benjamin y Brecht, seguidos de las prácticas provocativas de Joyce y Gombrowicz.

Todo proyecto literario de ruptura siempre se encuentra en evolución. La literatura de Ricardo Piglia ha intentado y logrado escapar de los lugares comunes de interpretación que la crítica literaria muchas veces ha intentado en ella, al clasificarla y sistematizarla.

Si la recepción inicial de Respiración artificial se ubicó en el contexto de la dictadura militar de los años setenta y ochenta, y uno de los aspectos que la crítica estudió y divulgó con mayor grado de repetición fue el de la resistencia social a través de la creación literaria, 
hay que tomar en cuenta que la novela sobrevivió a este encasillamiento y, aunque la función social es una constante fundamental en la poética pigliana, lo que va a perdurar de la novela no necesariamente tiene que ver con el momento político en que fue escrita, sino con las formas artísticas que exploran la capacidad de expresión. Por eso, a Juan José Saer le interesa más que la primera novela de Piglia sea una "novela-ensayo" que el tema de la dictadura argentina.

La lectura que intentó hacerse en este trabajo indagó en los aspectos fantásticos de la novela, siempre en contacto con los procedimientos que le dieron forma y sentido a la narración; el estudio del empleo de la autorreferencialidad, la metaficción, la intertextualidad, trató de poner en evidencia las condiciones estéticas y políticas del autor argentino, que dialoga con la tradición literaria de Argentina y de otros países, como Inglaterra, Irlanda, Francia, Polonia y los latinoamericanos, principalmente. Al llevar a cabo esta empresa siempre política, siempre poética, Piglia amplió la órbita de sus lecturas para producir nuevos espacios de reflexión que garantizaran, por lo menos parcialmente, la sobrevivencia de lo que entendemos por literatura. Es en la labor literaria donde se aprende a saber qué es la literatura, si bien nunca hay un acercamiento definitivo, que por otro lado terminaría por anularla.

El acercamiento marginal que se hizo de la obra de Piglia tuvo que seguir una ruta que muchas veces fue lateral, se cruzó por pasillos angostos pero altamente significativos. Las referencias bibliográficas, reales y falsas que el escritor argentino ha diseminado en su narrativa y en sus textos reflexivos fueron un objetivo para revelar parte de su proyecto literario. Así, la presencia oculta o sesgada de Walter Benjamin, Bertolt Brecht, Saul Bellow, Philip K. Dick, Malcolm Lowry, Alexander Kluge, amplía la espiral del corpus 
para proponer nuevas claves y nuevos modos de leer, a caballo entre la ruptura, la vanguardia y la función social.

Una de las marcas más recientes para el estudio de la obra de Piglia, por parte de la crítica actual, sería el Diario. Esta obra, a la que solo hemos tenido acceso de modo fragmentario (y a la que cada vez más nos acercamos, debido no tanto al paso del tiempo sino a la disposición del autor para hacernos llegar sus notas), ya se había anticipado en viejos textos y en obras más recientes. "Prisión perpetua" nos ofrece la escritura de un joven aprendiz de escritor que se acerca por primera vez a la literatura estadounidense; las "Notas sobre literatura en un Diario" y las "Notas sobre Macedonio en un Diario", de Formas breves, son adelantos y reiteraciones del cruce entre lo real y lo ficcional; Respiración artificial ofrece el diario de un muerto, de Enrique Ossorio, que logra cancelar el pasado mediante la creación de 1979, su novela utópica. Al mismo tiempo, nos enseña que en el pasado se encuentran las claves para comprender el presente y el futuro. Finalmente, el "Diario de un loco" de Stevensen es el texto que más anuncia la llegada de lo que suponemos será un grueso volumen que contenga relatos ficcionales-autobiográficos al lado de reflexiones iluminadoras de la tradición literaria que simultáneamente orienten la recepción en la obra de Piglia. Más allá de este estudio sobre literatura fantástica, metaficción e intertextualidad, el Diario de Piglia resolverá y despejará los titubeos de la crítica, como ya ha empezado a hacerse, además de que propondrá nuevos espacios de confusión y debate. No cabe duda que el Diario, el laboratorio del escritor, permite ensayar (en el doble sentido del término) en los significantes, polémicos y exasperantes descubrimientos de Piglia en su faceta de crítico (que al mismo tiempo evita el discurso tradicional y los canales por donde la crítica navega), su propia obra y su poética, a la que se puede llegar mediante el análisis de lo que él mismo, perversamente, sugiere: 
a) Provocar un nuevo modo de leer exasperando la poética de Borges, creando en sus textos de reflexión y de creación un modo altamente novedoso, con nuevos grados de significación, que han terminado por desplazar (sin dejar de actualizar) los descubrimientos teóricos de Borges, a propósito de la defensa del plagio como práctica literaria legítima, llevándolos a terrenos no pensados del todo por este, como la posibilidad de una literatura anónima, colectiva y democrática, como un cruce entre Calvino y Brecht: nuevo modo de pensar en la ya clásica dicotomía Arlt-Borges.

b) En la recuperación de la vanguardia marxista, pensando de modo central en Benjamin, Brecht, Adorno y Kluge, Piglia deja entrever uno de sus postulados al unir, a la manera de la teoría semiótica de los formalistas rusos y Mukarovsky, el lado del significante con el lado del significado: la función estética frente a la función social. La literatura fantástica, en Piglia, es un modo de salir del realismo producido por el Estado. En ese gesto subversivo, descansan los procedimientos formales que garantizarán el futuro y la desautomatización de la literatura.

c) Leer a Arlt mediante la invención-transcripción de un cuento ruso a la manera de Borges; ubicar implícitamente La ciudad ausente en la órbita de lo fantástico, al lado de las grandes novelas que la tradición literaria ha ubicado dentro de la poética de lo urbano; leer Los adioses de Onetti como la respuesta del escritor uruguayo a Borges y Emir Rodríguez Monegal cuando exaltan a Henry James, sin que estos nunca hubieran podido notar que esa nouvelle puede ser leída como un texto que desplaza el sentido realista para proponerse como una narración de fantasmas, rompiendo así la clásica lectura que postula que Otra vuelta de tuerca es ambigua; imaginar un final realista y regionalista para Adán Buenosayres, lo que invertiría el intento de Marechal por hacer una novela cosmopolita, en un claro juego irónico que nuevamente cimbraría el canon y la poética de la ciudad; leer el 
Ulysses desde Eichenbaum y el resto de los formalistas como una sugerencia para leer sus textos de ficción; ponerse a dialogar con Emilio Renzi sobre personajes reales y ficcionales, en un gesto inequívoco que logra exasperar y mezclar las nociones de realidad y ficción, son algunos momentos críticos que contradicen toda postura que tienda a la inmovilidad y el estancamiento: las múltiples lecturas y las novedosas aproximaciones no permiten pensar en el concepto de "Obras completas", es decir, no permiten la muerte de la obra una vez que ha sido sacralizada por el régimen político en turno y la clase intelectual dominante. Se trata, ante todo, de volver a reflexionar en torno a esas obras fundadoras (o de ruptura, dependiendo del caso) para producir nuevos espacios de diálogo. En la creación del género “ficción paranoica" puede observarse la transición del género policial clásico y el género negro: ahora, el enigma cede ante los nuevos tiempos oscuros: "la gavilla que tiene el poder absoluto" es la representación culminante de un sistema que se aferra a sus métodos de enriquecimiento y vigilancia mientras aumenta la desigualdad social. La literatura se convierte, como en Plata quemada o la novela utópica de Enrique Ossorio, en un modo de supervivencia humana:

En el año 2100, cuando el nombre de todos los autores se haya perdido y la literatura sea intemporal y anónima, esta pequeña propuesta sobre el desplazamiento y la distancia, será, tal vez, un apéndice o una intercalación apócrifa en un web.site llamado Las seis propuestas que para ese entonces serán leídas como si fueran consignas en un antiguo manual de estrategia usado en tiempos difíciles.

La pérdida de la noción de autor, en un proceso final inverso a la invención persecutoria del concepto de autor en otros tiempos difíciles, los de la inquisición, de acuerdo con Foucault, tendría en la cita anterior no un momento apocalíptico, sino una idea de esperanza, sugerida también en los finales de Respiración artificial y La ciudad ausente: la carta póstuma de 
Ossorio dirigida a Alberdi, a pesar de todo; la reflexión de Elena, abandonada toda esperanza de reencuentro con Macedonio, pero eligiendo la función de cantora, de máquina benjaminiana que preserve los relatos perdidos para mantener la resistencia social.

En La vida breve, Brausen inventa un mundo que le ayuda a escapar, temporalmente, del fracaso y el silencio. Su estancia en la cárcel de permitirá, al final de la novela, compartir el destino de su personaje Díaz Grey al tiempo que propiciará la reaparición de Larsen y el resto de sus personajes en las novelas y nouvelles posteriores. Onetti inventa Santa María como Piglia inventa los relatos de la máquina Elena. Ambos proyectos exceden sus novelas de origen y salen a un espacio textual abierto, donde todo es posible. Sin embargo, la mirada revolucionaria de Piglia se materializa en la alegoría de una máquina de narrar capaz de sugerir la apropiación revolucionaria de los medios tecnológicos para volver a narrar, una y otra vez, sin que importe tanto de dónde proviene el relato original, dándole a la literatura una función social a medida que va desprendiéndose de sus trampas ideológicas, impuestas desde el poder. Así, más allá de los nombres Borges, Arlt, Onetti, Piglia, la literatura sobrevivirá después de la Galaxia Gutenberg, en un signo lingüístico siempre dual diseminado en los textos, una vez que el nombre del autor haya desaparecido y solo queden rastros de las lenguas antiguas, en el tránsito angustiado a la otra orilla del lenguaje, rodeando las islas. 


\section{ANEXO. ENTREVISTA A RICARDO PIGLIA}

$(03 / 04 / 2010)$

Me ha citado a la una de la tarde, después de dedicarse al trabajo creativo de la mañana, como acostumbra desde hace años, según lo he leido en alguna entrevista.

Toco el timbre y unos minutos después me recibe Emilio Renzi, quien va de salida. Me indica el nivel y el número del departamento de esa calle de Marcelo T. de Alvear que está tan cerca de la Avenida Santa Fe y del Grand Splendid, ese antiguo teatro que ahora funciona como librería y que ha sido el lugar de las acciones de "El espectro" de Horacio Quiroga.

Ricardo Piglia nos abre la puerta de su departamento, nos ofrece agua y té, que sirve sobre una mesa minimalista que funciona como un escritorio provisional.

La estancia es amplia; hay unos cuantos muebles -el departamento es el estudiolaboratorio del escritor-; destaca un ancho librero que llega hasta la ventana del extremo y al que no me atrevo a consultar. Frente al librero se encuentra una reproducción de una de las imágenes clásicas de La naranja mecánica: el joven Alex DeLarge que mira al espectador de modo amenazador, mucho tiempo antes del trabajo de manipulación e integración a la sociedad al que será sometido por las fuerzas policiales.

Mientras saco la grabadora, Claudia, mi esposa, fotografia a Piglia en el momento en que lo mira revisando el ejemplar de Rulfo que acabo de obsequiarle: se trata de un volumen con fotografías del autor de Pedro Páramo que tomó en Hidalgo y otros estados durante los años previos a la publicación de su novela y su volumen de cuentos: ruinas de haciendas, paisajes, niños corriendo... Piglia pone atención a la primera imagen: se ve de lejos al joven Juan Rulfo, al pie de un árbol. 
A su vez, el escritor argentino me regala un ejemplar de Cuentos morales, la antología que publicó para Espasa y luego para Planeta, obra inhallable en México, como toda la obra de Juan José Saer, reducido, editorialmente, al Cono Sur.

Tengo ese material únicamente en fotocopias, le comento a Piglia. Así, le agradezco la dedicatoria. Renzi ha vuelto y se sienta cerca de la ventana, alejado de la mesa: lo veo atento, dispuesto a la polémica.

Alfonso Macedo (AM): En una entrevista concedida a Marithelma Costa en el 86, en Hispamérica, publicada posteriormente en Crítica y ficción, usted menciona a Steve Ratliff como su mentor literario; sin embargo, después, en otra entrevista, en 1993, con Edmundo Magaña, para La jornada semanal, usted afirma que Ratliff es un personaje ficcional. ¿Esto se debe a la estrategia narrativa de construir una figura de escritor? ¿O es una necesidad de transitar entre la ficción y la autobiografía?

Ricardo Piglia (RP): No. Bueno, por un lado, uno puede decir que la figura de Ratliff la podemos entender como alguien que ha tenido importancia en mi formación: lo que me motivó a trabajar sobre Ratliff es la idea de que él condensa para mí la literatura norteamericana, de modo que no importa si el personaje es real o no. No importa si el personaje existió o no existió porque quizá uno puede también imaginar mucha gente que se condensa sencillamente en la figura de Ratliff; lo que yo trataba en cierto sentido de elaborar a partir de él, digamos, es esa relación que yo tengo desde hace muchos años con alguien que tuve, sobre todo en unos años, en una época, con la literatura norteamericana. Funciona de esa manera. 
AM: Yo veo una relación entre Ratliff y Stephen Stevensen. Pienso que forma parte de un cambio en su poética y ahora que usted habla sobre este personaje que representaría la literatura estadounidense...

RP: Un diálogo con la literatura norteamericana. Entonces como ese diálogo es un tanto abstracto, muchas veces ese diálogo se materializa, a veces es una figura real y a veces es una figura imaginaria; entonces, para mí es importante que esas relaciones con la tradiciones múltiples aparezcan a veces encarnadas en personas reales, en sujetos con los cuales uno puede mantener un diálogo con la tradición.

AM: Y por eso Stevensen representa la línea británica.

RP: Un poco, porque también ahí se representan mis relaciones con el género del diario. Por lo que yo recuerdo, Stevensen está obsesionado por la relación entre lo que escribe en un diario y lo que sucede en la realidad, que es una experiencia que todos tenemos cuando escribimos un diario, registrar un diario es una escritura extraña en relación a los acontecimientos. Yo lo he dicho muchas veces, uno a veces registra en un diario hechos que luego no recuerda. Cosas escritas en el diario, uno no recuerda; eran muy importantes en el momento en que uno las anotó en el diario y sin embargo uno no las recuerda hasta que no las lee, y a la inversa: cosas que para uno son muy importantes, muchas veces el diario no registra. Entonces ese tipo de experiencias, ya no con la literatura norteamericana, sino más bien la experiencia con la escritura, durante muchos años, de un diario, de pronto se convierte en una ficción y se materializa en un sujeto. Eso es un poco lo que yo puedo decir sobre ese tema. Es tan válido lo que yo digo como lo que puede decir cualquier otro, pero la idea sería trabajar con algunos personajes o algunos sujetos a partir de los cuales es posible establecer un diálogo con cierto tipo de experiencia personal. En un caso, la literatura norteamericana; en otro caso, la escritura de un diario. 
AM: Por eso, quizá, usted habla, en una carta con Sergio Waisman, sobre las citas: él tenía una duda sobre las citas y usted le dijo: "Una cita habría que pensarla como el señor Melville, como el señor Freud", y me parece que ahí se produce un juego muy inquietante en relación con la intertextualidad.

RP: Yo tiendo a distanciarme de la noción de intertextualidad como un camino de la crítica que busca siempre rastros de otros textos; más bien tiendo a pensar en lo que decíamos ahí, en el sentido de pensar las relaciones con textos ya leídos, con el espíritu con que uno recuerda a los viejos amigos, momentos de la vida de uno que a veces están encarnados en personas reales y a veces están encarnados en sujetos con los que uno tiene una relación muy intensa pero imaginaria, como es el caso de Melville, que forman parte de la experiencia de todos nosotros pero a la vez son sujetos ajenos.

AM: Es posible que eso también se pueda relacionar con Macedonio Fernández, sobre todo por el trabajo de investigación que usted ha realizado, tomando en cuenta su intención de darle una nueva significación a su obra, por ejemplo, la entrada "Complot" en el Diccionario de la Novela de Macedonio Fernández, donde se habla de que el complot "funciona en la oposición de existencias posibles que encierra cada uno de los espacios". Toda esta relación se puede, de alguna forma, ubicar dentro de un género, como el fantástico. Y en ese sentido, mi pregunta es: ¿se puede hacer una relación entre La ciudad ausente y La sonámbula?

RP: Sí. Yo creo que La sonámbula podría ser un relato de la máquina, podría formar parte de la novela en la medida de que La ciudad ausente es una novela sobre mundos posibles, sobre realidades alternativas, sobre cómo en una ciudad hay muchas ciudades y entonces en un punto uno podría imaginar que La sonámbula es como un desvío del mundo que está presente en La ciudad ausente y de hecho Spiner había leído La ciudad ausente 
cuando me llamó para ver si escribíamos juntos una película, así que es cierto lo que dices, que La sonámbula está emparentada un poco por la atmósfera del relato, con la novela; aunque no es, desde luego, una adaptación de la novela, pero sí tiene que ver con el espíritu.

AM: Sí, por ejemplo, Kluge es el personaje cuyo nombre desapareció de la versión final de La ciudad ausente; es decir: aparecía primero en "Otra novela que comienza”, ¿no es así?

RP: ¡Es cierto! No me acordaba de eso. ¿Aparecía ahí?

AM: Sí, de acuerdo con lo que he estado buscando sobre ese pretexto; recuerdo que alguien por ahí escribió que es Kluge el nombre de Russo, el nombre original del científico en la novela.

RP: No me había dado cuenta. Bueno, no me acordaba.

AM: Ahí se encuentra la presencia de lo científico.

RP: Claro, claro. Ahí tenemos una conexión que está bien. Esto probaría de un modo nuevo, distinto, o abriendo otro camino, esa conexión entra la novela y la película.

AM: En "Un cadáver sobre la ciudad”, de Formas breves, usted menciona, en un estilo autobiográfico, que Juan C. Martini Real le mostró una serie de fotos del velorio de Roberto Arlt. Habla de que el féretro, con el cuerpo del escritor, por ser muy grande, no cabía en el pasillo y lo sacaron por la ventana. Esto le generó una molestia a Bolaño, que en un ensayo se queja de que lo anterior solo pasó en su imaginación.

RP: Espero que no sea una queja.

AM: Es que el estilo... no sé...

RP: ¿Él decía que eso no había sido real? 
AM: Sí, él lo menciona de ese modo, y lo que yo le estaría preguntando sería si no es acaso esto, de alguna forma, una evidencia más del juego entre la realidad y la ficción.

RP: Yo supongo que sí. Yo recuerdo, de todas maneras, la situación. Martini Real es un escritor ya muerto, un argentino conocido...

AM: De su generación...

RP: Sí. Y fue un editor importante. Él fue el editor de La muerte y la niña de Onetti, de la primera edición que salió en Corregidor, donde él trabajaba, y yo estaba un día en la oficina de él, en Corregidor, y él me mostró esa foto, de modo que tendríamos que hacer un ejercicio espiritista para traer aquí a Martini Real y también a Bolaño porque también ha muerto. Pero yo creo que, otra vez, eso no importa tanto en la literatura; en otros registros de la realidad eso sí es muy importante, definir el lugar de la verdad: en la política, en la historia... pero me parece que la ficción, justamente, se define porque no es ni verdadera ni falsa; la ficción es esa indeterminación, que es al mismo tiempo verdadera pero no lo es, es el registro de la ficción que en la literatura encuentra su plano más exigente, y con mayor tradición; en otros campos de la experiencia social no funcionan de esa manera; en ese sentido, yo me separo de las posiciones un poco cínicas de los posmodernos, digamos, por llamarlos así, que quieren ver a la ficción diseminada por todos los espacios, entonces utilizan esta relación entre ficción y no ficción, o entre ficción y realidad, también en la política, como si no hubiera verdad, como si todo fuera, al mismo tiempo, válido; como si todo en el fondo valiera lo mismo. Yo no lo creo, pero creo que la literatura investiga esa relación, nos hace conocer los matices de esa tensión entre la ficción y la realidad, mientras que en el resto de la experiencia social que no es la literatura, esas relaciones son más claras, y las manipulaciones que tienden a producir efectos de la realidad cuando no lo son tienen que ver con la política, los medios... me parece que la literatura es un campo de 
experimentación de esa relación; entonces, todas esas historias que estamos recuperando acá, si existe o no existió, si la foto existió o no existió, en fin, todo eso, me parece que hace el intento de pedirle a la ficción una respuesta que la ficción no puede dar, porque la ficción es esa indeterminación en el sentido de que nos produce un efecto que es el efecto de suspenso, yo diría... esto que estoy leyendo sucedió o no sucedió, sucedió en un sentido, ¿no? Desde luego, más allá de la existencia de las fotos, se trataba de una metáfora; fuera real o no la foto, es una metáfora decir que Arlt sigue ahí, insepulto todavía y en el aire. Si no recuerdo más, podríamos hablar de Bolaño. Bolaño me parece que tenía con respecto a Arlt -porque él decía que hubiera sido mejor que yo en lugar de dedicarme tanto a Arlt me dedicara más a Gombrowicz, cosa que yo hacía por mi lado desde luego-... pero me parece que la relación con Roberto Arlt o Macedonio Fernández son relaciones que fuera de la literatura argentina producen efectos perturbadores. Son escritores difíciles de registrar en la literatura latinoamericana, escritores difíciles de poner, de clasificar en algún lugar, sobre todo Arlt, pues yo creo que Macedonio cada vez más está disputando un espacio a propósito de su relación con Borges...

AM: Sí, hay una línea que se opone a lo que usted afirma: la poética de la oralidad, con Arguedas, Rulfo y, por otro lado, la otra poética, la del trópico...

RP: Exacto... pero quiero decir que la distancia -o no sé cómo llamarla- de Bolaño y otros escritores amigos, en relación a la literatura argentina, pasa a veces por la particularidad de la circulación de Roberto Arlt, que es un escritor que nosotros valoramos mucho, que solamente nosotros lo valoramos; sólo nosotros decimos con toda naturalidad que Arlt es igual a Borges, pero cuando uno va a Uruguay ya la gente no piensa que Arlt es igual a Borges; las cosas empiezan a cambiar, quiero decir: Arlt es una figura un poco rara... No soy el único, digamos, si uno habla acá con los escritores sobre la potencia y la 
importancia de Arlt... además Arlt nos salvó de Borges, Arlt nos salvó de Borges porque si solo hubiera sido mundo Borges eso hubiera sido muy sofocante. Entonces Arlt es como una apertura absoluta que, combinando los dos, se podían hacer algunas cosas, como hizo Onetti, como hicieron otros escritores, porque si se quedaba encerrado en ese mundo de Borges, era difícil sobrevivir a ese enclaustramiento borgiano. Así que también la importancia de Arlt tiene que ver con el hecho de cómo los escritores jóvenes que empezaban a escribir en la Argentina se enfrentaban con la figura de Borges que estaba ahí como una especie de...

AM: De Dios Padre...

RP: De ave, sí, no sé... de ave carroñera, no sé... podés poner cualquier imagen, ¿no? Por ejemplo, si uno lee la conversación -que a mí me parece muy anticuada-sobre el libro de Bioy, donde él anota sus conversaciones con Borges, es un libro donde uno ve que la vida, la experiencia que tenían Borges y Bioy era muy cerrada, muy ligada a la Academia de la lengua, muy ligada a los diarios oficiales, después Borges hacía con eso cosas extraordinarias, pero como modelo de vida literaria, era muy cerrado ese mundo. En cambio Arlt es la ciudad, la calle; me parece que por ahí pasa la cuestión.

AM: Su relación con el cine ya está bastante documentada; tiene usted un texto sobre el cine en Crítica y ficción; le han hecho algunas entrevistas al respecto. Sin embargo, a mí me gustaría pensar en la posibilidad de ubicar La ciudad ausente dentro de una línea o de una tradición que no sólo incluya la literatura, sino también el cine. En ese sentido, me parece que La ciudad ausente sostiene un diálogo, a veces evidente, a veces sugerido, implícito, con Alphaville, con La sonámbula, como usted ya lo afirmó, incluso con Metrópolis. 
RP: Sin duda. Y con Blade Runner. Por un lado, la relación de toda mi generación y de todos los escritores que tienen, más o menos, mi edad, hemos vivido una relación con el cine muy intensa y hemos tenido un diálogo emotivo con el cine. Se podría hablar de Puig, se podría hablar de Saer, se podría hablar de Bolaño, en fin, muchos escritores hemos tenido con el cine una relación muy continua, y por lo tanto la presencia del cine cada uno habría que encontrarla del mejor modo en que funcionan. En cierto sentido, me parece que yo he buscado en el cine ciertas soluciones que a veces se dan a cuestiones que la literatura se está planteando. Por ejemplo, Godard, siempre me ha parecido un punto de referencia importante, porque Godard utiliza de una manera muy particular los textos y las citas en los films; entonces, yo me sentía cerca, imaginariamente, de Godard, sencillamente porque Godard estaba haciendo algo con las narraciones cinematográficas que suponía la inclusión de citas, de estilos que se estaban leyendo. Parecía que por ese lado había una transformación...

AM: Y por eso usted lo considera un gran narrador.

RP: Uno de los grandes narradores de los años de los que estamos hablando, de modo que las relaciones con el cine deben ser vistas también en modo dinámico, de qué modo la literatura influye en el cine, de qué manera la literatura ha construido espectadores del cine y de qué manera eso ha producido algunos films a los cuales nosotros siempre hemos estado muy atentos, porque no olvidemos que Alphaville juega todo el tiempo alrededor de Borges. Alphaville termina con esa máquina extraña que termina citando textos de Borges. Esos eran los textos que a nosotros nos parecían siempre textos de ruptura donde había cruces entre la literatura y el cine.

AM: La cita, precisamente, permite trasladar de un lado a otro; juega mucho con la idea de la permanencia. 
RP: Exactamente. Entonces, por ese lado yo vería cierto tipo de convicción. A la vez, La ciudad ausente es una novela que fue escrita por mí en el momento justo porque es una novela que pareciera que anticipa... no que anticipa sino que... como el internet... hay máquinas que traducen textos y que los producen, no existían en ese momento. Creo que hubiera sido difícil escribir esa novela ahora porque teníamos que habernos hecho cargo de máquinas que ya no son esas máquinas de narrar que producen textos, sino serían estas máquinas actuales. Es una novela escrita en el año noventa, cuando estaba empezando a desarrollarse. Entonces, no solamente tiene, me parece, conexión con el cine sino también tiene conexión con los modos en que circulan textos y circulan imágenes en esa ciudad y, posteriormente, en el mundo actual, en esas máquinas múltiples que tenemos donde todo se entrevera.

AM: Por eso la imagen tan poderosa del subte en la película y en La ciudad ausente, que atraviesa todo prácticamente.

RP: Sí, sí, claro.

AM: ¿Qué entiende por el concepto de "literatura fantástica"?

RP: Es un concepto muy productivo, como sabemos, construido por Borges para enfrentar la dominante de la literatura realista, para establecer un espacio en el que hacer posible una escritura que no fuera leída con los cánones o criterios de la literatura realista. Ese sería el primer sentido que tienen. Borges se hace cargo de un nombre que viene de la literatura en lengua inglesa y que tiene un sentido distinto en el siglo XIX; más bien se habla ahí de vampiros, de fantasmas... es una literatura que se llama literatura fantástica a ese tipo de trabajos más conectados con el terror, con la literatura de horror, aparecidos, puntos después de la muerte, todo ese tipo de historias. En cambio, Borges le da un sentido totalmente conceptual, completamente conceptual más que temático, al género, y construye, 
alrededor del género, primero, una reacción frente al realismo, y, por lo tanto, una poética de la narración, que es una de las grandes poéticas que se han construido no sólo en América Latina. Ahí es donde él es muy deudor de Macedonio, que es el primero que empieza a construir sus hipótesis en contra del realismo, como camino central de la literatura, no solo en lengua castellana. Primero habría que leerlo en ese sentido, como una colocación de Borges en toda una polémica muy activa en aquel momento, que es: ¿cómo salimos del realismo?, es decir, ¿cómo hacemos una literatura que no sea realista y que sea leída como tal y no con los criterios que el realismo impone?, que era el tipo de lectura que recibían los textos de Borges cuando aparecieron, que eran textos que pasaban en lugares rarísimos, que no tenían que ver con la realidad argentina, que eran textos ajenos a las necesidades... Lo leían desde el realismo como un escritor que se escapaba de lo natural, mientras que él decía que el realismo es una forma de narrar y esta es otra forma de narrar. Eso es un poco, me parece, el criterio de lo fantástico, es un criterio que muchos hemos tratado de redefinir y también de mantener esa diferencia en el sentido de que el realismo no es la única manera de hacer literatura, es un género como cualquier otro, eso es lo que Borges viene a decir. Ahora, ¿cómo se puede definir ese procedimiento? ¿Cómo se produce el efecto fantástico? Es una cuestión más compleja que excede, un poco, la posibilidad de la conversación, ahora. Me parece que el paso siguiente sería empezar a ver cuál es el procedimiento que produce el efecto fantástico, en qué consiste; la cuestión de la incertidumbre entre ficción y realidad es un poco el paso que podríamos empezar a dar para definir lo fantástico, mientras que en el realismo esa relación está saldada, solo se narra aquello que se vuelve algo real y por lo tanto lo que se dice puede ser verificado en la realidad y tiende a adelgazar, a hacer casi mínima esa vacilación entre ficción y realidad. Lo fantástico tiende a poner esa relación como un elemento de investigación porque, en 
definitiva, la pregunta siempre es: ¿pero esto sucede o no? Esto me parece que es la pregunta de lo fantástico. Borges ha hecho trabajos extraordinarios, porque también ahí aparece Borges que está hablando, que habla con Bioy Casares, eso en el mundo de Tlön... así que yo diría: ¿ese Bioy Casares existe o no existe? Ese Borges que va ahí caminando por la ciudad y se encuentra con el Aleph, ¿qué Borges es?

AM: Si yo viera algún indicio de la literatura fantástica en su obra, lo puedo ver justamente como algo que, por lo general, se vincula con la crítica social. La crítica literaria toca, por lo general, aquellos aspectos de resistencia social en su obra, pero casi no habla de la literatura fantástica salvo unas cuantas excepciones.

RP: Es verdad.

AM: En ese sentido, sí hay un vínculo mucho más claro entre fantástico y sociedad. Uno puede pensar, con Saúl Sosnowski, por ejemplo, y otros críticos, que ya hay en Borges una mirada crítica a un sistema, a un régimen, pero me parece que todavía no hay una plena conciencia, y ya en usted, en sus obras, sí se alcanza a ver que, incluso, la literatura fantástica cumple una función social.

RP: Está muy bien eso, sí. O sea que es así, no solo en mi literatura, ojalá, sino que, en general, no se ha visto -es verdad lo que dices-, no se ha visto en ese tipo de literatura, se le ha visto como pura evasión habitualmente, y sin embargo tiene un carácter muy corrosivo. Así que por ese lado estoy totalmente de acuerdo con tu hipótesis, no debemos circunscribir la intervención de la literatura en lo real solamente en términos de la reproducción fiel de los modos en que la sociedad funciona dentro de la literatura realista, sino que se pueden construir mundos alternativos que son críticas al presente y que eso es una gran tradición, también, de Swift para abajo.

AM: Como la sátira, aunque ya no tanto ahora. 
RP: No, claro, pero funciona en la construcción de un universo imaginario, que en realidad es un modo de criticar o de referirse a cuestiones que pasan en una realidad que está ajena, que no es una realidad directa. Si uno lee una novela donde todo sucede en México, en la Revolución mexicana, esto tiene que ver con una posición sobre la Revolución mexicana, pero si uno lee una novela que sucede en una isla fantástica, como puede ser La invención de Morel, se puede encontrar ahí con observaciones sobre el mundo científico, sobre las manipulaciones científicas, sobre el peso de las imágenes y demás que son un elemento que se podría utilizar para leer también ahí lo social.

AM: Y creo que por eso ya había, también, un indicio de todo esto que usted, al parecer, ha ido explorando con mayor frecuencia en las últimas décadas, digamos desde los noventa para acá. Pienso, por ejemplo, en Respiración artificial, en esas cartas que Arocena intercepta, esas cartas donde alguien, no sabemos quién exactamente, está escribiendo para un destinatario en Buenos Aires, y habla de lo que lee, por ejemplo una novela de Saul Bellow, es lo mismo que él está viendo; entonces, yo creo que ahí ya existe un indicio de lo fantástico, aunque siempre está enmarcado por la duda.

RP: Está bien eso, sí. Esas cosas son, desde luego, observaciones muy inteligentes sobre la novela que escapan un poco a mis posibilidades de comentar porque son cosas que uno hace pero que se pueden ver de ese modo, está la idea de alguien que está escribiendo cartas para el porvenir, que en realidad ese futuro es el presente; el presente de la novela es en realidad las cartas que este hombre está enviando desde el siglo XIX.

Entonces, me da la sensación que tenemos mayor libertad en el trabajo narrativo a partir de la experiencia de Borges y que eso es visible, me parece, en mucho de lo que se está escribiendo en lengua castellana o no sólo en lengua castellana, actualmente. Lo que se ve en Bolaño, puede ser Vila-Matas... escritores que están utilizando elementos que parten 
de una literatura que es realista que está interferida por movimientos, interrupciones, que remiten a la literatura fantástica, sin ser estrictamente literatura fantástica en el sentido clásico. 


\section{B I B L I O G R A F Í A}

\section{a) Obras de Ricardo Piglia.}

-Blanco nocturno, Anagrama / Colofón, Barcelona-México, 2010 (Narrativas hispánicas, 476).

-"Clase media: cuerpo y destino (Una lectura de La traición de Rita Hayworth de Manuel Puig)", Actual. Revista de la Universidad de los Andes (Mérida), año II, núm. 6, enero-abril de 1970, s. n. pp.

-Crítica y ficción, Anagrama, Barcelona, 2001 (Argumentos, 267).

-Cuentos con dos rostros, selec. y epíl. de Marco Antonio Campos, pról. de Juan Villoro, UNAM, México, 1999 (Confabuladores).

-Cuentos morales. Antología personal (1961-1990), introducción de Adriana Rodríguez Pérsico, Espasa Calpe, Buenos Aires, 1995 (Austral).

-Cuentos morales. Antología personal (1961-1990), Planeta, Buenos Aires, 1997 (Bolsillo).

-Diccionario de la Novela de Macedonio Fernández, (ed. de R. P.), FCE, Buenos Aires, 2000 (Tezontle).

-"El escritor como lector", en Rose Corral (ed.), Entre ficción y reflexión. Juan José Saer y Ricardo Piglia, El Colegio de México, México, 2007.

-“El fotógrafo de Flores”, 2001, publicado en un tríptico de presentación a la exposición de arte latinoamericano El final del eclipse y reproducido en la página oficial www.fundacion.telefonica.com/at/eclipse/eclipse 05.html, página consultada el 18 de enero de 2007.

-"El laboratorio de Ricardo Carreira", www.poesia.com/n18/n18 it03a.htm, página consultada el 18 de enero de 2007.

-"El lugar de Saer", en Jorge Carrión (comp., pról. y ed.), El lugar de Piglia. Crítica sin ficción, Candaya, Barcelona, 2008.

-El último lector, Anagrama, Barcelona, 2005 (Narrativas hispánicas, 376).

-Formas breves, 2a ${ }^{\text {a }}$ ed., Anagrama, Barcelona, 2001 (Narrativas hispánicas, 292).

-"Homenaje", en Nicolás Bratosevich y Grupo de Estudio, Ricardo Piglia y la Cultura de la contravención, Atuel, Buenos Aires, 1997 (Los Argentinos). 
-“Homenaje a Julio Cortázar”, Casa de las Américas (La Habana), año XXXVI, núm. 200, julio-septiembre de 1995, pp. 97-102.

-“Ideología y ficción en Borges", en Pablo Brescia y Lauro Zavala (comps.), Borges múltiple. Cuentos y ensayos de cuentistas, UNAM, México, 1999 (El Estudio).

-La Argentina en pedazos, Ediciones de la Urraca, Buenos Aires, 1993 (Col. Fierro).

-La ciudad ausente, Anagrama, Barcelona, 2003 (Narrativas hispánicas, 340).

-La ciudad ausente, adaptación y pról. de Pablo de Santis, ilustraciones de Luis Scafati, Libros del Zorro Rojo, Barcelona-Madrid, 2008 (La novela gráfica).

-“La honda”, Atenea (Concepción), núm. 473, 1996, pp. 108-109.

-La invasión, Anagrama/Colofón, Barcelona-México, 2006 (Narrativas hispánicas, 404).

-La invasión, Editorial Jorge Álvarez, Buenos Aires, 1967 (Narradores Americanos).

-"La loca y el relato del crimen”, en Lauro Zavala, Cuentos sobre el cuento. Teorías sobre el cuento IV, UNAM, México, 2010 (El Estudio).

-Las fieras (selec. y pról. de R. P.), Clarín / Aguilar, Buenos Aires, 1993.

-Nombre falso, Siglo XXI, Buenos Aires, 1975.

-Nombre falso, Seix Barral, Barcelona, 1994 (Biblioteca Breve).

-Nombre falso, Anagrama, Barcelona, 2002 (Narrativas hispánicas, 322).

-"Notas al margen de un ejemplar de Adán Buenosayres", en Leopoldo Marechal, Adán Buenosayres, edición crítica de Jorge Lafforgue y Fernando Colla, ALLCA XX / FCE / Université de París X, Madrid, 1997 (Colección Archivos, 31), pp. XV-XVIII.

-"Notas en un diario. Un detective privado", Babelia, sup. cult. de El país (Madrid), núm. 999, 15 de enero de 2011, http:/www.elpais.com/articulo/portada/detective/privado/elpepuculbab/20110115elpbabpor 65/Tes, página consultada el 8 de junio de 2011 .

-"Notas en un diario. El perro ciego", Babelia, sup. cult. de El país (Madrid), núm. 1003, 12 de febrero de 2011, p. 23.

-"Notas en un diario. El consejo de Tolstói”, Babelia, sup. cult. de El país (Madrid), núm. 1007, 12 de marzo de 2011, p. 23.

-“Notas en un diario. El piano”, Babelia, sup. cult. de El país (Madrid), núm. 1013, 23 de abril 
http://www.elpais.com/articulo/portada/piano/elpepuculbab/20110423elpbabpor_59/Tes, página consultada el 8 de junio de 2011.

-"Notas en un diario. El oso", Babelia, sup. cult. de El país (Madrid), núm. 1017, 21 de mayo de 2011, p. 23.

-"Notas en un diario. El bar de Scott Fitzgerald", Babelia, sup. cult. de El país (Madrid), núm. 1021, 18 de junio de 2011, http://www.elpais.com/articulo/portada/bar/Scott/Fitzgerald/elpepuculbab/20110618elpbab por_58/Tes, página consultada el 7 de julio de 2011.

-"Otra novela que comienza", Cultura y Nación, sup. cult. de Clarín, 7 de marzo de 1985, pp. $1-2$.

-Plata quemada, Anagrama, Barcelona, 2000 (Narrativas hispánicas, 291).

-"Pequeño proyecto de una ciudad futura", en Adriana Rodríguez Pérsico (comp.), Ricardo Piglia: una poética sin límites, Universidad de Pittsburgh, Pittsburgh, 2004 (Serie Antonio Cornejo Polar).

-"Pequeño proyecto de una ciudad futura", Letras libres (México), núm. 34, octubre de 2001, pp. 61-64.

-Polémica sobre realismo (comp. de R. P.), Editorial Buenos Aires, Barcelona, 1982.

-Prisión perpetua, Editorial Sudamericana, Buenos Aires, 1988.

-Prisión perpetua, Anagrama, Barcelona, 2007 (Narrativas hispánicas, 422).

-Respiración artificial, Anagrama, Barcelona, 2001 (Narrativas hispánicas, 300).

-Respiración artificial, pról. de Jorge Fornet, Casa de las Américas, La Habana, 2000 (literatura latinoamericana, 145).

-"Roberto Arlt: la ficción del dinero", Roberto Arlt, Los siete locos / Los lanzallamas, ed. crít. de Mario Goloboff, ALLCA XX / FCE / Université de París X, París, 2000 (Colección Archivos, 44), pp. 806-809.

-"Secreto y narración. Tesis sobre la nouvelle", en Eduardo Becerra (ed.), El arquero inmóvil. Nuevas poéticas sobre el cuento, Páginas de Espuma, Madrid, 2006, pp. 187-205.

-Tres propuestas para el próximo milenio (y cinco dificultades), FCE, Buenos AiresMéxico, 2001 (C. P., 607).

-"Una propuesta para el próximo milenio", Clarín, Buenos Aires, 1995, http://edant.clarin.com/diario/especiales/viva99/text5.htm, página consultada el 27 de agosto de 2011. 
-y Colectivo 12, ["Sobre Macedonio Fernández"], transcripción de Julia Rodríguez, en Mónica Bueno (comp.), Conversaciones imposibles con Macedonio Fernández, Corregidor, Buenos Aires, 2001.

-y Juan José Saer. Diálogo, Universidad Nacional del Litoral, Santa Fe, 1990.

\section{b) Entrevistas con el autor.}

-S/a, "Entrevista a Ricardo Piglia", 17 de julio de 2006, http://elcocinerosalvaje3.blogspot.com/search?q=Piglia, página consultada el 9 de julio de 2011.

-Alfieri, Carlos. "Ricardo Piglia: La lectura de los escritores siempre es una toma de posición”, Revista de Occidente, núm. 295, diciembre de 2005, pp.131-158.

-Ángel, Raquel. "Ricardo Piglia. Los pensadores ventrílocuos", Rebeldes y domesticados. Los Intelectuales frente al Poder, Ediciones El Cielo por Asalto, Buenos Aires, pp. 27-35.

-Beltrán, Rosa. "Entrevista con Ricardo Piglia. Escritor perseguido por personaje", La jornada semanal, sup. cult., de La jornada (México), núm. 267, 16 de abril de 2000, p. 7.

-Campos, Marco Antonio, "Epílogo. Entrevista con Ricardo Piglia”, en Ricardo Piglia, Cuentos con dos rostros, selec. y epíl. de Marco Antonio Campos, pról. de Juan Villoro, UNAM, México, 1999 (Confabuladores).

-Carrión, Jorge. "No hay que tomarse en serio a ningún escritor. Entrevista con Ricardo Piglia", en Jorge Carrión (comp., pról. y ed.), El lugar de Piglia. Crítica sin ficción, Candaya, Barcelona, 2008.

-Costa, Marithelma. "Entrevista. Ricardo Piglia”, Hispamérica, núm. 44, año XV, 1986, pp. 39-54.

-Gandolfo, Elvio. "Entrevista a Ricardo Piglia", Literatura argentina contemporánea, http://www.literatura.org/Piglia/Piglia.html, página consultada el 18 de enero de 2007.

-García, Gastón. “Entrevista a Ricardo Piglia”, Letras libres (México), núm. 147, marzo de 2011, pp. 68-73.

-González Álvarez, José Manuel. “Anexo. Entrevista a Ricardo Piglia”, En los “bordes fluidos": formas híbridas y autoficción en la escritura de Ricardo Piglia, Peter Lang, Bern, 2009, pp. 271-280.

-Lafforgue, Jorge, y Jorge B. Rivera, “Testimonio” (sobre la literatura policial; cfr. sección de crítica sobre el autor). 
-Madrazo, Jorge Ariel. "Entrevista a Ricardo Piglia”, Atenea (Concepción, Chile), núm. 473, 1996, pp. 95-107.

-Magaña, Edmundo. "Entrevista con Ricardo Piglia", La jornada semanal, sup. cult. de La jornada, núm. 201, 18 de abril de 1993, pp. 28-33.

-Montiel Figueiras, Mauricio. "Por una literatura infinita. Entrevista a Ricardo Piglia", Letras libres (México), mayo de 2003, http://www.letraslibres.com/index.php?art=8770, página consultada el 27 de agosto de 2011.

-Ovejero, Emiliano (en colaboración con Jorge Carrión). "Piglia y el cine", en Jorge Carrión, El lugar de Piglia, Crítica sin ficción, Candaya, Barcelona, 2008, pp. 225-263.

-Pereira, María Antonieta. "Entrevista con Ricardo Piglia", en Ricardo Piglia y sus precursores, trad. de Adriana Pagano, pról. de Noé Jitrik, Ediciones Corregidor, Buenos Aires, 2001, pp. 241-250.

-Saavedra, Guillermo. "Ricardo Piglia. El estado de la novela", La curiosidad impertinente. Entrevistas con narradores argentinos, Beatriz Viterbo, Rosario, 1993.

-Viereck, Roberto. "De la tradición de las formas de la experiencia. (Entrevista a Ricardo Piglia)", Revista Chilena de Literatura, núm. 40, mayo de 1992, pp. 129-138.

\section{c) Bibliografía crítica citada}

-Andreotti, Carolina, y Alejandro Chacón. "Uno siempre escribe contra algo", El mundo (Madrid), 9 de septiembre http://www.elmundo.es/elmundo/2010/09/09/cultura/1284069552.html, página consultada el 24 de julio de 2011.

-Avelar, Ibelder. "Máquina apócrifa, alegoría del duelo y poética de la traducción”, en Adriana Rodríguez Pérsico, (comp.), Ricardo Piglia: una poética sin límites, Universidad de Pittsburgh, Pittsburgh, 2004 (Serie Antonio Cornejo Polar), pp. 177-199.

-Barrenechea. Ana María. "Inversión del tópico del beatus ille en La ciudad ausente", en Adriana Rodríguez Pérsico, Ricardo Piglia: una poética sin límites, Universidad de Pittsburgh, Pittsburgh, 2004 (Serie Antonio Cornejo Polar), pp. 85-99.

-Berg, Edgardo H. Poéticas en suspenso. Migraciones narrativas en Ricardo Piglia, Andrés Rivera y Juan José Saer, Biblos, Buenos Aires, 2002.

-Bolaño, Roberto. “Derivas de la pesada", Entre paréntesis, Anagrama, Barcelona, 2004 (Argumentos, 316).

-Bratosevich, Nicolás, y Grupo de Estudio, Ricardo Piglia y la Cultura de la contravención, Atuel, Buenos Aires, 1997 (Los Argentinos). 
-Carrión, Jorge. "Dos por dos: la multiplicación pigliana. Prólogo" a El lugar de Piglia. Crítica sin ficción, Candaya, Barcelona, 2008.

-Corbatta, Jorgelina. Narrativas de la Guerra Sucia en Argentina (Piglia, Saer, Valenzuela, Puig), Ediciones Corregidor, Buenos Aires, 1999.

-Corral, Rose. Roberto Arlt. Una poética de la disonancia, El Colegio de México, México, 2009.

-De Grandis, Rita. Polémica y estrategias narrativas en América Latina. José María Arguedas, Mario Vargas Llosa, Rodolfo Walsh, Ricardo Piglia, Beatriz Viterbo Editora, Rosario, 1993 (Tesis).

-Dehennin, Elsa. "Subversión de la doxa narrativa en La ciudad ausente (1992) de Ricardo Piglia, en Nina Grabe, Sabine Lang y Klaus Meyer-Minnemann (eds.), La narración paradójica. "Normas narrativas" y el principio de la "transgresión”, Iberoamericana, Vervuert Verlag, Madrid, 2006, pp. 221-235.

-Demaría, Laura. Argentina-s. Ricardo Piglia dialoga con la generación del 37 en la discontinuidad, Ediciones Corregidor, Buenos Aires, 1999.

-Fornet Gil, Jorge. El escritor y la tradición en la obra de Ricardo Piglia (tesis de doctorado), El Colegio de México, México, 2000.

-----------. El escritor y la tradición. En torno a la poética de Ricardo Piglia, Letras Cubanas, La Habana, 2005.

------------. "Homenaje a Roberto Arlt o la literatura como plagio", Nueva Revista de Filología Hispánica (México), t. XLI, núm. 1, 1993, pp. 279-291.

Múltiple).

(ed.) Ricardo Piglia, Casa de las Américas, Bogotá, 2000 (Valoración

-García Castillo, Jesús Eduardo. "Conversación ausente en la ciudad al sur: silencio y circunlocución como estrategias mnemotécnicas en las obras de Ricardo Piglia y Marta Traba", Signos literarios, v. V, núm. 9, enero-junio de 2009, pp. 75-92.

-Godinas, Laurette. "Entre política y tradición: Ricardo Piglia, la filología y el lenguaje", Entre ficción y reflexión. Juan José y Ricardo Piglia, ed. de Rose Corral, El Colegio de México, México, 2007, pp. 177-191.

"La secreta sociedad: Arlt, Borges y Piglia", Signos literarios y lingüísticos (México), v. V, núm. 1, enero-junio de 2003, pp. 53-71. 
-González Álvarez, José Manuel. En los “bordes fluidos”: formas híbridas y autoficción en la escritura de Ricardo Piglia, Peter Lang, Bern, 2009.

-Grzegorczyk, Marzena. "Discursos desde el margen: Gombrowicz, Piglia y la estética el basurero", Hispamérica, núm. 73, año XXV, 1996, pp. 15-33.

-Kohut, Karl. “¿Literatura comprometida o literatura de la memoria?”, en Rose Corral (ed.), Entre ficción y reflexión. Juan José Saer y Ricardo Piglia, El Colegio de México, México, 2007, pp. 113-134.

-Macedo Rodríguez, Alfonso. De la crítica a la ficción y de la ficción a la crítica. Una lectura sobre la poética de Ricardo Piglia (tesis de maestría), Universidad Autónoma Metropolitana-Iztapalapa, México, 2007.

--------------, "La metaficción y la intertextualidad: figuras de lo fantástico en La ciudad ausente", Signos literarios, v. V, núm. 10, julio-diciembre de 2009, pp. 57-75.

-Masiello, Francine. "Cuerpos en tránsito: traducción y sexualidad", El arte de la transición, trad. de Mónica Sifrim, Norma, Buenos Aires, 2001.

, "La Argentina durante el proceso: las múltiples resistencias de la cultura", en Daniel Balderston, David William Foster y otros, La narrativa argentina durante el proceso militar, Alianza Editorial / Institute for the Study of Ideologies \& Literature, Buenos Aires-Madrid (Alianza Ensayo).

-Morello-Frosch, Marta. "Significación e historia en Respiración artificial", en Jorge Fornet (ed.), Ricardo Piglia, Casa de las Américas, Bogotá, 2000, pp. 149-162.

-Pereira, María Antonieta, Ricardo Piglia y sus precursores, trad. de Adriana Pagano, pról. de Noé Jitrik, Ediciones Corregidor, Buenos Aires, 2001.

-Poggiese, Diego. "El peso de una verdad otra (o cómo diseñar el monumento de uno mismo)", en Alberto Giordano y María Celia Vázquez (comps.), Las operaciones de la crítica, Beatriz Viterbo Editora, Rosario, 1998, pp. 147-167.

-Quintana, Isabel. "Experiencia, historia y literatura en la obra de Ricardo Piglia", Figuras de la experiencia en el fin de siglo: Cristina Peri Rossi, Ricardo Piglia, Juan José Saer, Silviano Santiago, Beatriz Viterbo, Rosario, 2001 (Tesis / Ensayo).

-Ruisánchez, José Ramón. "Heterotopías: imaginación política y espacio en Piglia y Aira", Signos literarios (México), v. II, núm. 3, enero-junio de 2006, pp. 43-59.

-Saer, Juan José. "Historia y novela, política y policía", en Adriana Rodríguez Pérsico (comp.), Ricardo Piglia: una poética sin límites, Universidad de Pittsburgh, Pittsburgh, 2004. 
-Santis, Pablo de. "Prólogo. Caligrafía nocturna", en Ricardo Piglia, La ciudad ausente, adaptación de Pablo de Santis, ilustraciones de Luis Scafati, Libros del Zorro Rojo, Barcelona-Madrid, 2008 (La novela gráfica).

-Sequera, Magalí. "El relato-río: la gauchesca en La ciudad ausente", en Jorge Carrión, El lugar de Piglia. Crítica sin ficción, Candaya, Barcelona, 2008, pp. 65-82.

-Speranza, Graciela. "Ricardo Piglia o el arte del desvío", Fuera de campo. Literatura y arte argentinos después de Duchamp, Anagrama, Barcelona, 2006 (Fundamentos, 351).

-Vila-Matas, Enrique. “Descifrar el arte de narrar”, en Jorge Carrión (comp., pról. y ed.), El lugar de Piglia. Crítica sin ficción, Candaya, Barcelona, 2008.

-Villoro, Juan. "La máquina desnuda. Sobre Respiración artificial”, Biblioteca Virtual Miguel de Cervantes, www.cervantesvirtual.com/servlet/SirveObras/bameric/07038330969692039647857/p0000 $\underline{001 . h t m \# I \_0}$, página consultada el 30 de junio de 2010.

-Waisman, Sergio. "Máquinas creadoras, sitios de resistencia: Ricardo Piglia y la traducción”, en Adriana Rodríguez Pérsico (comp.), Ricardo Piglia: una poética sin limites, Universidad de Pittsburgh Pittsburgh, 2004.

-Weinberg, Liliana. "La máquina de escribir", en Rose Corral (ed.), Entre ficción y reflexión. Juan José Saer y Ricardo Piglia, El Colegio de México, México, 2007, pp. 161175.

\section{d) Otras referencias bibliográficas sobre Ricardo Piglia}

-Albero, Danilo. ["Ricardo Piglia"], La jornada semanal, sup. cult., de La jornada (México), núm. 267, 16 de abril de 2000, pp. 8-9.

-Berg, Edgardo H. "El relato ausente. (Sobre la poética de Ricardo Piglia)", en Elisa Calabrese y otros, Supersticiones de linaje. Genealogías y reescrituras, Beatriz Viterbo Editora, Rosario, 1996 (Tesis / Ensayo), pp. 139-158.

-------------, "La conspiración literaria (sobre La ciudad ausente de Ricardo Piglia)", Hispamérica, núm. 73, año XXV, 1996, pp. 37-47.

-Brescia, Pablo A. J. "Ricardo Piglia y el cuento ausente: el género de la posmodernidad", en Ana Rosa Domenella y otros (comps.), Medio siglo de literatura latinoamericana, 19451995. Primer Congreso Internacional de Literatura, v.2, UAM, México, 1997, pp. 169177.

-Carrión, Jorge. "La novela múltiple”, Letras libres (México), núm. 143, noviembre de 2010, pp. 86-87. 
-Corral, Rose. "Los usos de Arlt”, en Adriana Rodríguez Pérsico (comp.), Ricardo Piglia: una poética sin límites, Universidad de Pittsburgh, Pittsburgh, 2004 (Serie Antonio Cornejo Polar), pp. 249-258.

-Domenella, Ana Rosa. "Los lectores de la tribu”, en Rose Corral (ed.), Entre ficción y reflexión. Juan José Saer y Ricardo Piglia, El Colegio de México, México, 2007, pp. 97112.

-Dove, Patrick. "Heterotopic Memory and the Narration of Disaster in Piglia", The Catastrophe of Modernity. Tragedy and the Nation in Latin America Literature, Bucknell University Press, Lewisburg, 2004, pp. 222-285.

-Echavarren, Roberto. "Escritura y voz, II: Respiración artificial de Ricardo Piglia", Margen de ficción. Poéticas de la narrativa hispanoamericana, Joaquín Mortiz, México, 1992 (Cuadernos).

-Gallo, Marta. "In-trascendencia textual en Respiración artificial de Ricardo Piglia", Nueva Revista de Filología Hispánica (México), t. XXXV, núm. 2, 1987, pp. 819-834.

-Giardinelli, Mempo. El género negro. Ensayos sobre literatura policial, 2a. ed., Universidad Autónoma Metropolitana, México, 1996 (Molinos de Viento, 106).

-Gnutzmann, Rita. "Homenaje a Arlt, Borges y Onetti de Ricardo Piglia", Revista Iberoamericana, núm 158, v. 58, 1992, pp. 437-448.

-Jitrik, Noé. "En las manos de Borges el corazón de Arlt. A propósito de Nombre falso de Ricardo Piglia”, Cambio, núm. 3, abril-junio de 1976, pp. 84-88.

-Lafforgue, Jorge y Jorge B. Rivera. Asesinos de papel. Una introducción: historia, testimonios y antología de la narrativa policial en la Argentina, Calicanto Editorial, Buenos Aires, 1977.

-Marimón, Antonio. “¿Cómo escribir hoy en Argentina, si es imposible?”, Revista de la Universidad de México (México), vol. 36, núm. 3, julio de 1981, pp. 46-49.

-Menton, Seymour. "Cuestionando las definiciones o el arte de la subversión. Respiración artificial de Ricardo Piglia", La nueva novela histórica de la América Latina, 1979-1992, FCE, México, 1993 (C. P., 490).

-Molina, Mauricio. "La ciudad ausente de Ricardo Piglia”, Vuelta, núm. 193, dic. de 1992, pp. 50-51.

-Morello-Frosch, Marta. "Borges y los nuevos: ruptura y continuidad", Revista de Crítica Literaria Latinoamericana (Lima), núm. 34, año XVII, 2do. semestre de 1991, pp. 105120. 
-Olguín, Sergio, y Claudio Zeiger, "La narrativa como programa. El realismo frente al espejo", en Susana Cella (dir.), Historia de la literatura argentina. La irrupción de la crítica, v. 10, Emecé, Buenos Aires, 2000.

-Oviedo, José Miguel. "Ricardo Piglia", Historia de la literatura hispanoamericana 4. De Borges al presente, Alianza Editorial, Madrid, 2001 (Alianza Universidad Textos).

-Pacheco, José Emilio. “Blanco nocturno. Ricardo Piglia, Premio Rómulo Gallegos 2011”, Proceso (México), núm. 1806, 12 de junio de 2011, pp. 60-61.

--------------, “Kafka y Hitler. El proceso, El castillo, las alambradas”, Proceso (México), núm. 350, 18 de julio de 1983, pp. 46-47.

-Pellicer, Rosa. "Libros y detectives en la narrativa policial argentina”, Hispamérica, núm. 93, año XXXI, 2002, pp. 3-18.

-Rivera, Jorge B. El relato policial en la Argentina. Antología crítica, Editorial Universitaria de Buenos Aires, Buenos Aires, 1986.

-Rodríguez Pérsico, Adriana (comp). Ricardo Piglia: una poética sin límites, Universidad de Pittsburgh, Pittsburgh, 2004 (Serie Antonio Cornejo Polar).

-Romano Thuesen, Evelia A. "Marcelo: el presente sin presencia en Respiración artificial de Ricardo Piglia”, Nueva Revista de Filología Hispánica (México), t. XLI, núm. 1, 1993, pp. 279-291.

-Shaw, Daniel L. Nueva narrativa hispanoamericana. Boom, Posboom, Posmodernismo, Cátedra, Madrid, 1999 (Crítica y estudios literarios).

-Solomianski, Alejandro. "El cuento de la patria. Una forma de su configuración en la cuentística de Ricardo Piglia", Revista Iberoamericana, v. LXIII, núm. 181, octubrediciembre de 1997, pp. 675-688.

-Stanton, Anthony. "Narrar la historia: ética y experimentación en José Emilio Pacheco y Ricardo Piglia", en Rose Corral (ed.), Norte y sur: la narrativa rioplatense desde México, El Colegio de México, México, 2000, pp. 47-55.

-Villoro, Juan. "Piglia, private eye”, Letras libres, núm. 77, año VII, mayo de 2005, p. 64.

\section{e) Bibliografía de consulta.}

-Alazraki, Jaime. En busca del unicornio: Los cuentos de Julio Cortázar. Elementos para una poética de lo neofantástico, Gredos, Madrid, 1983

-Arán, Pampa O. El fantástico literario. Aportes teóricos, Narvaja Editor, Córdoba, 1999. 
-Arlt, Roberto. Los siete locos. Los lanzallamas, ed. crít. de Mario Goloboff (coord.), FCE/ALLCA XX, París, 2000 (Archivos, 44).

-Bajtín, Mijaíl. Estética de la creación verbal, trad. de Tatiana Bubnova, Siglo XXI, México, 1992.

-Barrenechea, Ana María, "La expresión de la irrealidad en la obra de Jorge Luis Borges", en Ana María Barrenechea y Emma Susana Speratti Piñero. La literatura fantástica en Argentina, UNAM, México, 1957.

-Barth, John. "Literatura del agotamiento", en Pablo Brescia y Lauro Zavala (comps.), Borges múltiple. Cuentos y ensayos de cuentistas, UNAM, México, 1999 (El Estudio).

-Barthes, Roland. "La muerte del autor", en Nara Araújo y Teresa Delgado (selec. y apuntes introductorios), Textos de teorías y crítica literarias (Del formalismo a los estudios coloniales), Universidad de la Habana/UAM-I, México, 2003.

-Belevan, Harry. Teoría de lo fantástico. Apuntes para una dinámica de la literatura de expresión fantástica, Anagrama, Barcelona, 1976 (Argumentos, 37).

-Bellow, Saul. El planeta de Mr. Sammler, trad. de Rafael Vázquez Zamora, Random House Mondadori, Barcelona, 2005 (DeBolsillo, 584).

-Benjamin, Walter. Baudelaire. Un poeta en el esplendor del capitalismo. Iluminaciones II, pról. y trad. de Jesús Aguirre, Taurus, Madrid, 1972.

--------------, Estética y política, trad. de Tomás Joaquín Bartoletti y Julián Fava, pról. de Ralph Buchenhorst, Las Cuarenta, Buenos Aires, 2009.

--------------, Para una crítica de la violencia, selec. y trad. de Marco Aurelio Sandoval, Premià, México, 1977 (La nave de los locos).

, Para una crítica de la violencia y otros ensayos, Taurus, Madrid, 1991.

-Bioy Casares, Adolfo. Historias fantásticas, Alianza Editorial, Madrid, 2000.

-Borges, Jorge Luis. Biblioteca personal, Alianza Editorial, Madrid, 1999.

---------------, El Aleph, Alianza Editorial, Madrid, 1999.

----------------, El informe de Brodie, Alianza Editorial, Madrid, 2008.

, Ficciones, Alianza Editorial, Madrid, 2000.

, La memoria de Shakespeare, Alianza Editorial, Madrid, 1998.

, Nueva antología personal, Siglo XXI, México, 1998. 
--------------, Obra poética, 1, Alianza Editorial, Madrid, 1999.

, Obra poética, 3, Alianza Editorial, Madrid, 1999.

---------------, Otras inquisiciones, Alianza Editorial, Madrid, 1981.

--------------, y Adolfo Bioy Casares. Cuentos breves y extraordinarios, Losada, México, 1997.

--------------, Adolfo Bioy Casares y Silvina Ocampo. Antología de la literatura fantástica, Sudamericana / Hermes, México, 1996.

y Esther Zemborain. Introducción a la literatura norteamericana, Alianza Editorial, Madrid, 1999.

-Botton Burlá, Flora. Los juegos fantásticos. Estudio de los elementos fantásticos en cuentos de tres narradores hispanoamericanos, UNAM, México, 1983.

-Bradbury, Ray. Fahrenheit 451, trad. de Alfredo Crespo, Random House Mondadori, México, 2008 (Debolsillo).

-Caillois, Roger, Antología del cuento fantástico, Sudamericana, Buenos Aires, 1970.

-Calloni, Stella. "Comienzan en Argentina juicios contra represores de la pasada dictadura", La jornada, $10 \quad$ de julio de http://www.jornada.unam.mx/2007/07/11/index.php?section=mundo\&article=033n1mun, página consultada el 23 de febrero de 2011.

-Cortázar, Julio. Cuentos completos 1, Alfaguara, México, 2001.

-Dällenbach, Lucien. El relato especular, Visor, Madrid, 1991 (Literatura y Debate Crítico, $8)$.

-Deleuze, Gilles, y Félix Guattari, Kafka. Por una literatura menor, trad. de Jorge Aguilar Mora, Era, México, 2001.

-Dick, Philip K. El hombre en el castillo, trad. de Manuel Figueroa, Minotauro, Buenos Aires, 2007.

-Duncan, Cynthia K. "Hacia una interpretación de lo fantástico en el contexto de la literatura hispanoamericana", Texto crítico (Xalapa), v. XVI, núms. 42-43, enero-diciembre de 1990, pp. 53-64.

-Eco, Umberto. Apocalípticos e integrados, trad. de Andrés Boglar, Lumen-Tusquets, México, 2004. 
Barcelona, 1988.

De los espejos y otros ensayos, trad. de Cárdenas Moyano, Lumen,

-Fernández, Macedonio. Museo de la Novela de la Eterna (Primera novela buena), Obras completas, v. 4, Corregidor, Buenos Aires, 2010.

-Frenzel, Elizabeth, Diccionario de argumentos literarios, trad. de Carmen Schad de Caneda, Gredos, Madrid, 1976.

-Freud, Sigmund. Obras completas, t. III, trad. de Luis López Ballesteros y de Torres, Biblioteca Nueva, Madrid, 1981.

-Garro, Elena. La semana de colores, Porrúa, México, 2006.

-Genette Gérard. Metalepsis. De la figura a la ficción, trad. de Luciano Padilla López, FCE, Buenos Aires, 2004 (C. P., 650).

------------, Nuevo discurso del relato, trad. de Marisa Rodríguez Tapia, Cátedra, Madrid, 1998 (Crítica y estudios literarios).

------------, Palimpsestos. La literatura en segundo grado, trad. de Celia Fernández Prieto, Taurus, Madrid, 1989 (Persiles, 195).

-------------, Umbrales, trad. de Susana Lage, Siglo XXI, México, 2001.

-Hoffmann, E. T. A. Cuentos, 1, trad. de Carmen Bravo-Villasante, Alianza Editorial, Madrid, 2002.

-Hughes, Patrick, y George Brecht, "Círculos viciosos e infinitud", Revista de Occidente (Madrid), tercera época, núms. 5 y 6, marzo-abril de 1976, pp. 90-94.

-Hutcheon, Linda. A Theory of Parody. The Teachings of Twentieth-Century Art Forms, University of Illinois Press, Urbana-Chicago, 2000.

--------------, “Ironía, sátira, parodia. Una aproximación pragmática a la ironía”, trad. de Pilar Hernández Cobos, en De la ironía a lo grotesco (en algunos textos literarios hispanoamericanos), UAM-I, México, 1992.

-Jakobson, Roman. "Lingüística y poética", en Nara Araújo y Teresa Delgado (selec. y apuntes introductorios), Textos de teorías y crítica literarias (Del formalismo a los estudios postcoloniales), UAM-I / Universidad de la Habana, México, 2003, pp. 185-211.

-------------, “Sobre el realismo artístico", en Tzvetan Todorov (comp.), Teoría de la literatura de los formalistas rusos, Siglo XXI, México, 1991, pp. 71-79.

-James, Henry. El último de los Valerio y otros cuentos, trad. de Fernando Jadraque, Valdemar, Madrid, 1997. 
-Jauss, Hans Robert. Experiencia estética y hermenéutica literaria, trad. de Jaime Siles y Ela Ma. Fernández Palacios, Taurus, Madrid, 1986.

-Kristeva, Julia. Semiótica, v. 1, trad. de José Martín Arancibia, Fundamentos, Madrid, 1978.

-Lowry, Malcolm. Bajo el volcán, trad. de Raúl Ortiz y Ortiz, Era, México, 2008.

-Ludmer, Josefina. "Los escándalos de Juan Moreira”, en Josefina Ludmer (comp.), Las culturas de fin de siglo en América Latina, Beatriz Viterbo Editora, Rosario, 1994 (Estudios Culturales).

-Macedo Rodríguez, Alfonso. "La metaficción como recurso de lo fantástico en La fiesta brava de José Emilio Pacheco", Signos literarios y lingüísticos, (México), v. V, núm. 1, enero-junio de 2003, pp. 227-237.

-Meyrink, Gustav. El Golem, trad., pról. y notas de Hugo Grünbaum, Juan Pablos Editor, México, 1991.

-Morales, Ana María, y José Miguel Sardiñas (eds.). Odiseas de lo fantástico, Coloquios Internacionales de Literatura Fantástica, México, 2004.

-Mukarovsky, Jan. "El arte como hecho semiológico", en Nara Araújo y Teresa Delgado (selec. y apuntes introductorios), Textos de teorías y crítica literarias (Del formalismo a los estudios postcoloniales), Universidad de la Habana / UAM-I, México, 2003.

-Murdoch, Iris. Un hombre, si acaso [An Accidental Man], trad. de Antonio Bonanno, Sudamericana, Buenos Aires, 1975.

-Negroni, María. Galería fantástica, Siglo XXI, México, 2009.

-Novaro, Marcos, y Vicente Palermo. La dictadura militar (1976-1983). Del golpe de Estado a la restauración democrática, Historia argentina 9, Paidós, Buenos Aires, 2003.

-Ovidio, Metamorfosis, trad. y ed. de Consuelo Álvarez y Rosa María Iglesias, Cátedra, Madrid, 2007 (Letras universales, 228).

-Pauls, Alan. Wasabi, Anagrama, Barcelona, 2005 (Narrativas hispánicas, 380).

-Pitol, Sergio. El arte de la fuga, Era / Editores independientes, México, 2007.

-Roas, David. "Contexto sociocultural y efecto fantástico: un binomio inseparable", en Ana María Morales y José Miguel Sardiñas (eds.), Odiseas de lo fantástico, Coloquios Internacionales de Literatura Fantástica, México, 2004. 
-Romero, Luis Alberto. Breve historia contemporánea de la Argentina, FCE, Buenos Aires, 2004.

-Saer, Juan José. Lugar, Seix Barral, Buenos Aires, 2006.

-Saussure, Ferdinand de. Curso de lingüística general, trad. de Mauro Armiño, Fontamara, México, 1998.

-Shklovsky, Víktor. "El arte como artificio", en Tzvetan Todorov (comp.), Teoría de la literatura de los formalistas rusos, Siglo XXI, México, 1991, pp. 55-70.

-Sosnowski, Saúl. "Contando nazis en Argentina", La jornada semanal, sup. cult. de La jornada, núm. 227, 11 de julio de 1999, pp. 4-5.

-Tinianov, Iuri. "Sobre la evolución literaria", en Tzvetan Todorov (comp.), Teoría de la literatura de los formalistas rusos, Siglo XXI, México, 1991, pp. 89-101.

-Todorov, Tzvetan. Introducción a la literatura fantástica, trad. de Silvia Delpy, Ediciones Coyoacán, México, 1999.

-Vila-Matas, Enrique. Bartleby y compañia, Anagrama, Barcelona, 2005 (Narrativas hispánicas, 279).

, El mal de Montano, Anagrama, Barcelona, 2007 (Compactos, 436).

-Xirau, Ramón. "Crisis del realismo", en César Fernández Moreno (coord. e introducción), América Latina en su literatura, Siglo XXI, México, 1978, pp. 185-203.

-Zavala, Lauro. Cuentos sobre el cuento. Teorías sobre el cuento IV, UNAM, México, 2010 (El Estudio). 